\author{
UNIVERSIDADE DE SÃO PAULO \\ FACULDADE DE FILOSOFIA, LETRAS E CIÊNCIAS HUMANAS \\ DEPARTAMENTO DE LETRAS MODERNAS \\ PROGRAMA DE PÓS-GRADUAÇÃO EM ESTUDOS DA TRADUÇÃO
}

Moriçá Santos de Souza Torres

\title{
Uma oferenda para Xangô: tradução comentada de Bahia, de Hubert Fichte
}

(versão corrigida)

São Paulo 


\section{Uma oferenda para Xangô: tradução comentada de Bahia, de Hubert Fichte}

Dissertação apresentada ao Programa de PósGraduação em Estudos da Tradução do Departamento de Letras Modernas da Faculdade de Filosofia, Letras e Ciências Humanas da Universidade de São Paulo para a obtenção do título de Mestre em Estudos da Tradução

Área de concentração: Estudos da Tradução, Literatura alemã contemporânea

Orientador: Prof. Dr. João Azenha Jr.

\section{DE ACORDO}

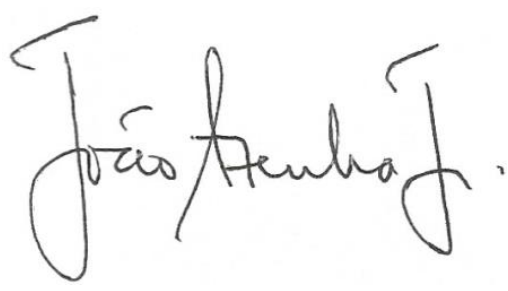

(versão corrigida)

São Paulo 
Nome: TORRES, Moriçá Santos de Souza.

Título: "Uma oferenda para Xangô: tradução comentada de Bahia, de Hubert Fichte"

Dissertação apresentada ao Programa de Pós-Graduação em Estudos da Tradução do Departamento de Letras Modernas da Faculdade de Filosofia, Letras e Ciências Humanas da Universidade de São Paulo para a obtenção do título de Mestre em Estudos da Tradução.

Aprovado em:

Banca examinadora

$\operatorname{Prof}\left({ }^{a}\right)$. Dr. $\left({ }^{a}\right)$. Instituição:

Julgamento: Assinatura:

$\operatorname{Prof}(\stackrel{a}{a})$. Dr. $\left(\stackrel{(}{a}^{-}\right)$ Instituição:

Julgamento: Assinatura:

$\operatorname{Prof}(\stackrel{a}{)})$. Dr. $(\stackrel{a}{)})$ Instituição:

Julgamento: Assinatura: 
Ao Thales Daksa. 


\section{Agradecimentos}

Meus agradecimentos especiais são para o meu orientador, Professor João Azenha Júnior, pela sua generosidade sem par, direcionamento e apoio, imprescindíveis para que eu levasse a cabo esse trabalho.

Ao meu filho, Thales Daksa, e à minha mãe, Vera, por reconhecerem o quanto esse projeto era importante para mim, e abrirem mão, muitas vezes, da atenção de que necessitavam e de momentos de lazer em família.

Às Professoras Claudia Sybille Dornbusch e Cristina Alberts Franco, pela crítica construtiva e honesta no meu exame de qualificação, dando um grande impulso à continuação desse trabalho.

Agradeço ao meu amigo Marcelo Galvão, por me auxiliar na procura e aquisição de material bibliográfico atualizado sobre a fortuna crítica de Hubert Fichte, inclusive como portador dessas obras trazidas da Europa.

À minha amiga-irmã Elza Trentinella, por me acompanhar em São Paulo nas entregas de trabalho na USP e na véspera do meu exame de qualificação, por todo seu carinho e palavras de incentivo.

Por fim, toda a minha gratidão aos meus tios Antônio, Benedita e Terezinha, in memoriam. Ao tio Tony, por ter despertado meu interesse por idiomas estrangeiros, em especial pelo alemão. À tia Ditinha, que me introduziu no universo da umbanda e do candomblé. E à tia Tetê, por ter me contagiado com seu interesse e fascínio por tradução. 
"A experiência da alteridade (e a elaboração dessa experiência) leva-nos a ver aquilo que nem teríamos conseguido imaginar, dada a nossa dificuldade em fixar nossa atenção no que nos é habitual, familiar, cotidiano, e que consideramos "evidente". Aos poucos, notamos que o menor dos nossos comportamentos (gestos, mímicas, posturas, reações afetivas) não tem realmente nada de "natural".

Laplantine

"Na obra poética, a novidade é obrigatória". 


\section{RESUMO}

TORRES, Moriçá Santos de Souza. Uma oferenda para Xangô: tradução comentada de Bahia, de Hubert Fichte. 2017. 253f. Dissertação (Mestrado) - Faculdade de Filosofia, Letras e Ciências Humanas, Universidade de São Paulo, São Paulo, 2017.

Esta dissertação apresenta uma tradução comentada de Bahia, um capítulo da obra Xangô. As religiões afro-americanas. Bahia, Haiti, Trinidad (1976), do autor alemão Hubert Fichte, obra ainda inédita no Brasil. O objetivo consiste em propor uma atitude recriadora da escrita fichteana sob a perspectiva diferenciada de quem traduz, mantendo as características do texto-fonte e a marca poética na análise etnográfica, e pela adoção de uma atitude tradutória estrangeirizante, trazer visibilidade para o tradutor. Além disso, a tradução serve como um exercício de análise e crítica da obra, e, por meio de escolhas e justificativas de decisões tradutórias, são revelados os bastidores do processo de tradução.

Palavras-chave: Hubert Fichte. Literatura alemã. Tradução literária. Estrangeirização. Domesticação. 


\begin{abstract}
This master thesis presents a commented translation of Bahia, a chapter of Xangô. As religiões afro-americanas. Bahia. Haiti. Trinidad (1976) by the German author Hubert Fichte - a work still unpublished in Brazil. The aim of this thesis is to propose a recreative attitude of the fichtean writing under a differing perspective of the individual who translates, maintaining not only the characteristics of the source-text but also the poetic features in the ethnographic analysis. The work also intends to provide visibility to the translator by adopting a foreign translating posture. In addition, translation itself serves as an exercise of analysis and critique of the work, and through choices and justifications of translating decisions, the underlying efforts of the translation process is revealed.
\end{abstract}

Keywords: Hubert Fichte. German literature. Literary translation. Foreignization. Domestication.

\title{
ZUSAMMENFASSUNG
}

Die vorliegende Masterarbeit präsentiert eine kommentierte Übersetzung von Bahia, einem Kapitel von Xangô. As religiões afro-americanas. Bahia. Haiti. Trinidad (1976) des deutschen Schriftstellers Hubert Fichte, ein noch unveröffentlichtes Werk in Brasilien. Das Ziel besteht darin, eine neue Übersetzungshaltung des Schreibens Fichtes unter der differenzierten Perspektive des Übersetzers zu gestalten, die die Eigenschaften des Quelltextes und die poetischen Merkmale in der ethnographischen Analyse beibehält, und durch eine verfremdende Übersetzungshaltung, die Sichtbarkeit des Übersetzers vermittelt. Darüber hinaus dient die Übersetzung als Übung in der Analyse und Kritik der Arbeit, und durch die Begründungen von Übersetzungsentscheidungen wird hinter die Kulissen geblickt und der Übersetzungsprozess aufgedeckt.

Schlüsselwörter: Hubert Fichte. Deutsche Literatur. Literarische Übersetzung. Verfremdung. Domestizierung. 


\section{LISTA DE ILUSTRAÇÕES}

Figura 1 - Capa da edição de Xangô de 1976 ..................................................... 29

Figura 2 - Capa do livro de fotografias Xangô de 1976 ....................................... 29

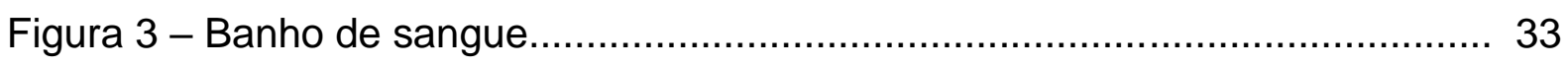

Figura 4 - Capa de edição de Xangô de 1984.................................................... 34 


\section{SUMÁRIO}

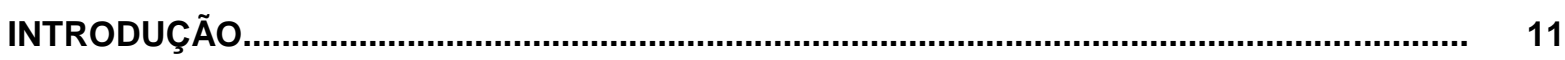

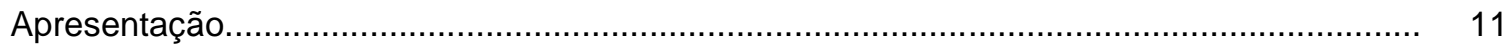

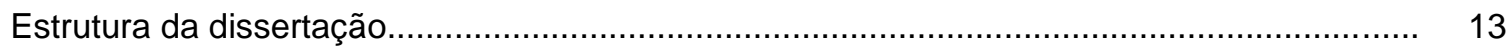

CAPÍTULO I - HUBERT FICHTE E XANGÔ................................................................. 15

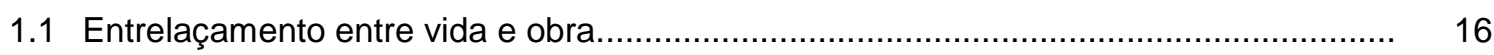

1.2 Xangô: a obra e suas características.................................................................... 21

1.2.1 Construção linguística da obra............................................................... 24

1.3 Hubert Fichte e Leonore Mau: a documentação dupla............................................. 27

CAPÍTULO II - SOBRE A MOLDURA TEÓRICA E A ESTRATÉGIA DE TRADUÇÃO............... 36

CAPÍTULO III - A TRADUÇÃO: MINHA OFERENDA PARA XANGÔ....................................... 48

Nota prévia à tradução....................................................................................... 48

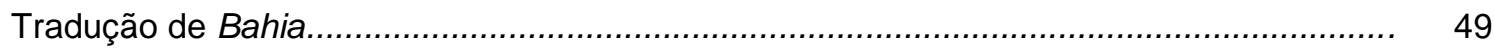

CAPÍTULO IV - COMENTÁRIOS À TRADUÇÃO DE XANGÔ..................................................... 203

1. Questões de sintaxe..................................................................................................... 205

2. Referências teuto - europeias......................................................................... 210

3. Questões lexicais............................................................................................... 223

3.1 Vocábulos de categoria gramatical variada............................................. 224

3.2 Termos estrangeiros................................................................... 230

3.3 Conservação de nomes próprios......................................................... 231

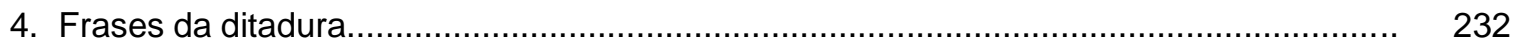

5. Questões relacionadas ao universo da religião - Identidade......................................... 233

6. Títulos de jornais, revistas, etc................................................................................... 238

CAPÍTULO V - CONSIDERAÇÕES FINAIS........................................................................ 241

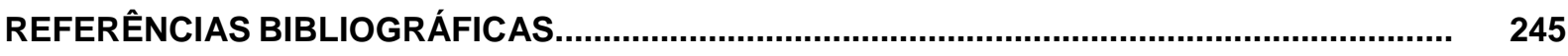

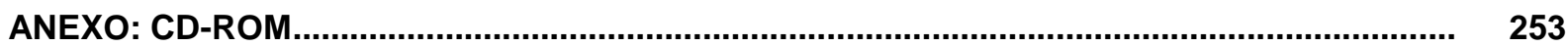




\section{Introdução}

\section{Apresentação}

Meu interesse pelo autor Hubert Fichte e sua obra teve início na época em que eu morava na Alemanha (1985 - 1992) e recebi de presente o livro Xango. Die afroamerikanischen Religionen. Bahia. Haiti. Trindad. Talvez por estar já há algum tempo naquele país, tentando lidar com minha vivência com a alteridade, essa leitura causou em mim um forte impacto: era como se eu estivesse redescobrindo minha própria cultura, com a qual eu havia deixado de ter contato diário na época. Foi como se alguém me houvesse defrontado com a minha realidade cultural, conduzindo-me a um resgate de mim mesma, de minhas memórias de infância, de quando frequentava o candomblé, acompanhando uma tia materna, que desempenhava funções como filha de santo, da lembrança de uma realidade política e social que ainda lançava reflexos nos fatos sociais da época, na década de 1980.

Dessa redescoberta surgiu minha quase necessidade de traduzir essa obra, era como se reescrever Xangô em português completasse essa minha experiência de leitura e a expandisse a experiência sensível que tive quando colocada em contato com a obra que agora pretendo investigar.

A escolha por Xango. Die afroamerikanischen Religionen. Bahia. Haiti. Trinidad (Xangô. As religiões afro-americanas. Bahia, Haiti, Trinidad) justifica-se por esta ser uma obra da chamada "trilogia etnopoética" de Hubert Fichte, que se compõe ainda de Petersilie. Die afroamerikanischen Religionen. Santo Domingo Venezuela Miami Grenada (Salsinha. As religiões afro-americanas. Santo Domingo Venezuela Miami Granada, 1980) e Lazarus und die Waschmaschine. Kleine Einführung in die afroamerikanische Kultur (Lázaro e a máquina de lavar. Pequena introdução à cultura afro-americana, 1985) que trata do Brasil e ainda se encontra inédita em nosso país, segundo pesquisa feita por mim na página da internet da Fundação Biblioteca Nacional, na seção de catálogo de livros e autores. 
Isso não significa que o autor não tenha ainda sido traduzido para o português. Dentre as traduções conhecidas de suas obras no Brasil, vale destacar o livro Etnopoesia. Antropologia poética das Religiões Afro-americanas (1987), lançado pela editora Brasiliense, com organização e prefácio de Wolfgang Bader, seleção de Hubert Fichte e Wolfgang Bader, e tradução de Cristina Alberts e Reny Hernandes. Ainda pela mesma editora foram publicados Ensaio sobre a puberdade (1986), com tradução e posfácio de Zé Pedro Antunes, e Hotel Garni. A História da Sensibilidade (1989), traduzido por Günther Hermann Wetzel. Pela editora Guanabara há ainda $O$ orfanato (1986), com tradução de Carlos Almeida Pereira.

Outro fator a ser destacado para a pesquisa é a relevância de um olhar estrangeiro sobre nossa própria cultura como um enriquecimento e expansão do (re)conhecimento de nossa própria identidade.

O objetivo do presente trabalho consiste, portanto, em traduzir uma obra inédita de Hubert Fichte no Brasil, e partindo do exercício de tradução, propor uma atitude recriadora da escrita fichteana, na medida do possível, sob a perspectiva diferenciada de quem traduz, mantendo as características do texto-fonte e a marca poética na análise etnográfica. Além disso, buscamos utilizar a tradução como um exercício de análise e crítica da obra, e por meio de escolhas e justificativas de atitudes tradutórias, revelar os bastidores do processo de tradução. Desse modo, pretendemos trazer visibilidade para o tradutor, que perde seu rosto num processo de domesticação da tradução, ou seja, na facilitação do texto de chegada. Reunindo todos esses elementos, temos, por fim, como escopo, criar e testar uma metodologia para a tradução elaborada e anotada de Xangô.

Os procedimentos metodológicos adotados para a pesquisa foram a pesquisa bibliográfica contemplando o texto-fonte, paratextos, parte da fortuna crítica de Hubert Fichte, obras do campo dos Estudos e da Teoria da Tradução, bem como fontes de apoio para os comentários da tradução. Além disso, adotamos como caminho para se atingirem os objetivos da pesquisa a tradução da obra que constitui o corpus.

Realizamos várias versões da tradução para, desse modo, construir uma metodologia em interação com a teoria. A primeira tradução foi feita com a atitude que utilizaríamos com outro tipo de texto diferente do literário. As demais serão 
feitas à luz de uma estratégia definida, mediante a definição de uma atitude tradutória mais consciente.

\section{Estruturação da dissertação}

A dissertação compõe-se de cinco capítulos. O capítulo I, "Hubert Fichte e Xangô", focaliza o autor Hubert Fichte e sua obra Xango. Die afroamerikanischen Religionen. Bahia. Haiti. Trinidad (Xangô. As religiões afro-americanas. Bahia, Haiti, Trinidad) e está subdividido em três partes. Na primeira apresento aspectos biográficos do autor contendo informações sobre elementos específicos da vida de Hubert Fichte que tenham influenciado sua obra e que reflitam uma relação de espelhamento relevante para o trabalho de tradução e suas notas, tais como as referências teuto-europeias, que se ancoram no seu conhecimento cultural e nas memórias de suas vivências. Para oferecer suporte à sua elaboração, utilizei uma bibliografia suplementar sobre sua biografia. O método de apresentação da trajetória biográfica será cronológico, facilitando a formação da noção de encadeamento entre vida e obra. A segunda parte do capítulo ocupa-se da descrição da obra, e estabelece um diálogo com a fortuna crítica relacionada especialmente à produção fichteana que aborda as religiões afroamericanas. Na terceira parte será abordada a parceria de vida e de trabalho entre Hubert Fichte e a fotógrafa alemã Leonore Mau, além de uma breve análise de três capas das edições de Xangô de 1976 e 1984, inclusive do livro fotográfico de Leonore Mau, que constitui um relato de viagem e leitura etnográfica apresentado em imagens.

O capítulo II, "Sobre a moldura teórica e a estratégia de tradução", contém breves considerações sobre as obras de Schleiermacher, Berman, Venuti, Nord, e Lefevere, teóricos dos Estudos da Tradução, que dão suporte à nossa estratégia de tradução proposta neste trabalho - uma proposta "estrangeirizadora", nos termos de Venuti (1995) -, porém conservando a (inte)legibilidade do texto.

No capítulo III, "A tradução: uma oferenda para Xangô", apresento a tradução da primeira parte de Xangô, denominada Bahia, em versão bilíngue. A tradução está antecedida de considerações sobre o método empregado neste trabalho. 
Já no capítulo IV apresento os comentários da tradução, organizados em tópicos e por afinidade, contemplando a estratégia de tradução, segundo as orientações dos teóricos de tradução sobre os quais discorremos no capítulo II dessa dissertação.

$\mathrm{O}$ capítulo $\mathrm{V}$ está destinado às considerações finais quanto à estratégia de tradução adotada, suas contribuições na apresentação da obra ao leitor brasileiro, bem como algumas reflexões, nas quais comparo minha vivência como tradutora no modo juramentado com essa nova experiência com tradução literária. 


\section{CAPÍTULO I}

\section{HUBERT FICHTE E XANGÔ}

\section{Kauô cabiecile ${ }^{1}$}

Esse capítulo focaliza o autor Hubert Fichte e sua obra Xango. Die afroamerikanischen Religionen. Bahia. Haiti. Trinidad (Xangô. As religiões afroamericanas. Bahia, Haiti, Trinidad). Ele está subdividido em três partes. Na primeira apresento aspectos biográficos do autor contendo informações sobre elementos específicos da vida de Hubert Fichte que tenham influenciado sua obra e que reflitam uma relação de espelhamento relevante para o trabalho de tradução e suas notas, tais como as referências teuto-europeias, que se ancoram no seu conhecimento cultural e nas memórias de suas vivências. Para oferecer suporte à sua elaboração, utilizei uma bibliografia suplementar sobre sua biografia. O método de apresentação da trajetória biográfica será cronológico, facilitando a formação da noção de encadeamento entre vida e obra. A segunda parte do capítulo ocupa-se da descrição da obra, reunindo material coletado na fortuna crítica relacionada especialmente à produção fichteana que aborda as religiões afro-americanas. Na terceira parte será abordada a parceria de vida e de trabalho entre Hubert Fichte e a fotógrafa alemã Leonore Mau.

\footnotetext{
${ }^{1}$ Kauô cabiecile! Saudação para o orixá Xangô, que significa: Ká (permita-nos); wô (olhar para); Ka biyê si (Sua Alteza Real); le (complemento de cumprimento a um chefe) - Permita-nos olhar para Vossa Alteza Real! Ou ainda, Venham admirar o Rei. In: CACCIATORE, Olga. Dicionário de Cultos Afro-Brasileiros. Rio de Janeiro: Editora Forense, 1977.
} 


\subsection{Entrelaçamento entre vida e obra}

Para destacar a existência e o papel de traços autobiográficos na obra de Hubert Fichte, valemo-nos de declarações do autor, como em uma entrevista a Peter Laemmle na emissora de rádio NDR: "As coisas que eu escrevi nos romances estão bem precisamente lá, no local e época em que elas aconteceram; elas são apresentadas no sentido biográfico mais estrito". ${ }^{2} \mathrm{E}$ em um outro momento, numa entrevista a Rüdiger Wischenbart, Fichte reitera essa característica: "Relata-se sempre sobre si mesmo. Cada frase expressa é uma frase que sai do próprio centro, do próprio eu". 3

Muito embora não se trate, em seus relatos, de autobiografia como gênero literário em sua acepção mais clássica, sua escrita é diretamente impulsionada e influenciada pelas suas experiências de vida. Portanto, consideramos necessário apresentar algumas estações biográficas do autor, relacionando-as com suas obras, especialmente com a primeira parte de Xangô, denominada Bahia, traduzida e comentada nessa dissertação.

Hubert Fichte nasceu em 21 de março de 1935 em Perleberg, no estado alemão de Brandemburgo. Algumas semanas após seu nascimento, mudou-se com sua mãe para a casa de seus avós em Hamburg-Lockstedt. Seu pai era judeu e emigrou nessa época para a Suécia. Foi tido depois como desaparecido. Portanto, Fichte não chegou a conhecê-lo. Sua mãe trabalhava na época como estenotipista e a avó materna cuidou dele a maior parte do tempo. Em 1941, foi enviado ao sul da Alemanha, em um programa do Partido Nacional-Socialista de proteção a crianças contraataques aéreos dos aliados (Kinderlandverschickung $-K L V$ ), em especial das cidades de Hamburgo e Berlim. No entanto, essa medida teve também como escopo ocultar e proteger o pequeno Hubert da perseguição nazista, devido a sua origem semijudaica ${ }^{4}$.

\footnotetext{
2 "Die Dinge, die ich in den Romanen geschrieben habe, sind ganz präzis dort am Ort und am Zeitpunkt, an dem sie stattgefunden haben; sie sind im strengsten biographischen Sinne dargestellt." (LAEMMLE, 1980).

Salvo indicação em contrário, todas as traduções das citações são minhas.

3 "Man berichtet ja immer von sich. Jeder Satz, den man ausdrückt, ist ein Satz, der aus dem eigenen Zentrum, aus dem eigenen ich herauskommt". (WISCHENBART, 1981: 67)

${ }^{4}$ A Lei de Cidadania do Reich (Reichsbürgergesetz) de 14 de novembro de 1935 negou o direito à cidadania à parcela não ariana da população. Em relação ao judeus, adotou-se o critério da genealogia familiar para classificar
} 
Nesse contexto, Fichte viveu durante um ano em um orfanato católico dessa região, na cidade de Schrobenhausen. Essa experiência tornou-se mais tarde assunto de seu primeiro romance, Das Waisenhaus (O orfanato), pelo qual recebe o prêmio Hermann Hesse de Literatura em 1965.

Detlev, o protagonista do romance, um menino de oito anos, filho bastardo de um pai judeu e uma mãe protestante, narra suas experiências em um universo católico marcado por rituais que ele não compreendia, a sensação de ter sido abandonado pela mãe, e principalmente do momento da despedida do orfanato, quando sua mãe vai buscá-lo e lhe conta que seu pai é judeu. Trata-se de uma revelação de um dos aspectos de sua marginalidade, numa sociedade dominada por padrões morais rígidos e um poder estatal antissemita.

Em 1944, já de volta à casa dos avós em Hamburgo, começa a escrever esboços de romances, dramas cavaleirescos e poemas. Sua mãe trabalhava como ponto de teatro, isto é, ela tinha a função de soprar o texto para os atores, caso esses se esquecessem de sua fala nas apresentações teatrais. Por intermédio de sua mãe, começa a frequentar o meio artístico ainda na infância e assume papéis infantis no teatro e no cinema. Com 12 anos de idade, Hubert Fichte ganhava mais como ator que sua mãe na atividade como ponto de teatro. Mais tarde, completa uma formação em arte dramática e trabalha em emissoras de rádio. Entretanto, sua carreira promissora como ator, pela qual havia abandonado a escola, é interrompida por uma inflamação nas cordas vocais, que não puderam ser mais recuperadas. $O$ fato desencadeia uma crise na vida de Fichte, pois seus trabalhos no teatro eram, para ele, um meio de sobrevivência. Desempregado e novamente dependente da mãe e dos avós, ainda assim, permanece firme no propósito de se tornar ator e escritor, como

um indivíduo como pertencente a esse grupo. Segundo essas determinações criadas pelos legisladores do regime nacional-socialista, semijudeus eram igualmente tratados como judeus. Essa designação se estendia a pessoas casadas com judeus, a mestiços em 1 o grau que fossem frutos de um casamento proibido pela Lei de Proteção ao Sangue, ou a filhos advindos de um relacionamento extraconjugal.

(http://www.judentum-projekt.de/geschichte/nsverfolgung/gesetze/. Acesso em 21. Mai 2017) 
declara através de seu alter ego ${ }^{5}$ Detlev, em Versuch über die Pubertät (Ensaio sobre a puberdade $)^{6}$, no seguinte trecho:

"Minha mãe vai comigo à orientação vocacional na Agência Nacional de Empregos da Ferdinandstraße [...]

Mas eu continuo firme:

- Ator e escritor" (FICHTE, 1979: 112) ${ }^{7}$

O recurso utilizado por Fichte como saída dessa situação de insatisfação e para perseguir seus propósitos de realização profissional e de vida é a fuga de casa, que representa igualmente um tipo de segundo nascimento, como aponta FISCH (2000). Empreende, então, viagens de estudo e de trabalho pela França e à Itália, e em 1954 trabalha no "Camp de la Pomponnette" em Paris, com Abbé Pierre-Grouè ${ }^{8}$. Junto a essa comunidade, Hubert Fichte realizou um trabalho voluntário, financiado por seus próprios meios financeiros. Em correspondência com seu ex-colega de escola, o pintor e litógrafo Peter Hinrik Boll, Fichte escreve sobre sua motivação e interesse nessas viagens e trabalhos, ocasiões em que tem a oportunidade de conviver com camponeses e grupos marginalizados: "Eu me pus em marcha para procurar os resquícios humanos, eu vivi com camponeses e, mais tarde, com os marginalizados e com os mais pobres dos pobres". ${ }^{9}$

Porém, devido a uma grave hepatite, teve que voltar para Hamburgo. Inicia seus estudos de Agronomia em Holstein no ano de 1955. Após a conclusão dessa formação universitária, vai para a Suécia como chefe do setor de agricultura de uma casa para crianças com transtorno de conduta. Durante esse período, estuda a

\footnotetext{
${ }^{5}$ Detelev é o alter ego de Fichte como criança. Há ainda outro alter ego, na idade adulta: Jäcki, que se relaciona com Irma, personagem que carrega traços biográficos de Leonore Mau.

${ }^{6}$ O romance Versuch über die Pubertät (1974) foi traduzido para o português por Zé Pedro Antunes. FICHTE, Hubert. Ensaio sobre a puberdade. São Paulo: Editora Brasiliense, 1986. A tradução do título foi retirada do exemplar já traduzido e publicado. A passagem apresenta tradução nossa.

7 „Meine Mutter geht mit mir zur Berufsberatung in das Arbeitsamt Ferdinandstraße [...]

Aber ich bleibe dabei:

- Schauspieler um Schriftsteller." (FICHTE, 1979: 122)

${ }^{8}$ Sacerdote católico francês, iniciou seu trabalho de assistência durante a Segunda Guerra Mundial, dedicandose a salvar pessoas perseguidas pelo nazismo. Organizou um grupo de resistência armada durante a Resistência Francesa e, vendo a exclusão dos homens no período de guerra, decidiu lutar contra as causas da injustiça, colocando-os para morar em um abrigo.

9 "Ich zog los, um die menschlichen Überreste aufzusuchen, ich lebte mit Bauern und später mit Asozialen und mit den Ärmsten der Armen." (BÖHME, H., TILING, N., 1991: 39 - 49)
} 
agricultura antroposófica, psicanálise, o idioma sueco e escreve sua primeira peça teatral, Masken und Tote (Máscaras e Mortos). Seguem-se outras viagens à Finlândia e à Provença, a produção de outra peça de teatro e as primeiras obras em prosa.

Em 1962, Fichte torna-se, enfim, escritor independente em Hamburgo e se muda para um pequeno apartamento com a fotógrafa Leonore Mau, sua companheira de vida e de trabalho, com quem desenvolveu projetos como Xango. Die afroamerikanischen Religionen. Bahia. Haiti. Trinidad. Sobre essa parceria, que durou cerca de 25 anos, falaremos mais adiante, no item 1.3 dessa dissertação.

Data também do início dos anos 60 sua primeira participação num encontro do Grupo 47, uma associação de autores de língua alemã como Günter Grass, Heinrich Böll e Hans-Magnus Enzensberger, que se reuniu anualmente de 1947 a 1967. Seus objetivos eram o esclarecimento e a educação das pessoas na Alemanha para a democracia no período pós-guerra, após o fim do regime totalitário de Hitler. Nos encontros do grupo, Hubert Fichte teve a oportunidade de travar contato com críticos literários como Hans Mayer, Marcel Reich-Ranicki e Dieter E. Zimmer, que mais tarde escreveram resenhas críticas sobre seus livros. Ficou conhecendo alguns colegas escritores, como Johannes Bobrowski, Hans Christof Buch, Gisela Elsner, Günter Grass, Uwe Johnson, Martin Walser, Helmut Heißenbüttel e Peter Weiss, que Ihe proporcionaram importante intercâmbio no processo literário. Travou contato com editores e leitores de importantes empresas do ramo editorial da Alemanha na época: Peter Frank e Klaus Roehler, da Luchterhand, Maria Ledig-Rowohlt e Fritz J. Raddatz da Rowohlt, Siegfried Unseld e Hans Magnus Enzensberger da Suhrkamp. Hubert Fichte realizou uma leitura pública do manuscrito de seu romance Das Waisenhaus (O Orfanato), que o romancista e poeta alemão Helmut Heißenbüttel (1921 - 1996) considerou mais tarde em um artigo como a "estrutura de um mundo novo". ${ }^{10}$

Nessa época inicia seu romance Die Palette ( $A$ Paleta), nome de um bar frequentado por malandros, travestis, homossexuais e outras figuras do submundo de Hamburgo, no qual o autor reúne material autêntico sobre a vida desses personagens, colhido por meio da convivência e de entrevistas realizadas com eles. Wangenheim

\footnotetext{
10 „Gerüst einer neuen Welt”

Heißenbüttel, Helmut. Strategie der Erzählkunst. Über Hubert Fichtes Roman „Das Waisenhaus”. In: Süddeutsche Zeitung. 11.09.1965.
} 
(1980:65) considera essa obra uma "saída do armário" de Fichte, em que ele fala publicamente sobre seu relacionamento com homens, alguns anos antes do movimento dos direitos civis.

Hubert Fichte sempre foi um viajante, mas as viagens passam a ocupar maior importância em sua vida no final dos anos 1960. Inicialmente, possuía interesse jornalístico nessas viagens curtas para a África e a América. Com o tempo, suas estadas ficam mais longas, pois servem a um propósito mais profundo de estudos. Do aumento da relevância de uma pesquisa sobre a cultura e a religião afro-americanas é que surgem suas obras desse ciclo, como Xangô. Ele fala sobre sua motivação pelo tema em uma entrevista: "Esses trabalhos de reportagem, esse interesse pelo Terceiro Mundo, em especial pelo mundo afro-americano, emergiram dos meus romances, principalmente de Imitações de Detlev <azinhavre>"11. Essa declaração indica a presença recorrente de temas em toda a sua obra, bem como as elaborações e os significados diferentes dos mesmos temas em suas obras seguintes. Para Fichte, seus quatro romances e as publicações sobre as religiões afro-americanas são estudos preparatórios de sua bem estruturada e grande obra, planejada para ser publicada em dezenove volumes, o roman fleuve "A história da sensibilidade".

Hubert Fichte conseguiu publicar seis volumes desse projeto até a sua morte em 8 de março de 1986, como escritor reconhecido e bem-sucedido. De 1963 até o final de sua vida, morou com Leonore Mau em uma boa residência em Othmarschen, um dos bairros mais ricos de Hamburgo.

As informações biobibliográficas expostas acima não pretendem ser exaustivas, constituindo apenas uma moldura que será complementada no capítulo IV desta dissertação, dedicado aos comentários à tradução, e no qual se encontram outros detalhes que ilustram como vida e obra se entrelaçam na produção literária de Hubert Fichte.

\footnotetext{
11 "Diese Reportagearbeit, dies Interesse an der Dritten Welt, insbesondere in der afroamerikanischen Welt, hat sich ja aus meinen Romanen, insbesondere aus Detlevs Imitationen <Grünspan>, herausgeschält." LINDEMANN, Gisela. In Grazie das Mörderische verwandeln (. Ein Gespräch mit Hubert Fichte zu seinem roman fleuve »Die Geschichte der Empfindlichkeit«. In: Sprache im technischen Zeitalter 104: 308.
} 


\subsection{Xangô: a obra e suas características}

Neste subcapítulo apresentamos a obra Xangô e suas características temáticas; fizemos algumas considerações sobre a proposta de etnopoesia, segundo Fichte, e abrimos um subitem sobre a construção linguística da obra.

O livro Xango. Die afroamerikanischen Religionen. Bahia. Haiti. Trinidad (Xangô. As religiões afro-americanas. Bahia, Haiti, Trinidad), do autor alemão Hubert Fichte (1935-1986), publicado em 1976, é um resultado das diversas viagens de Fichte às Américas, com o objetivo de estudar as religiões afro-americanas. Tratase de uma obra etnopoética, gênero em que o autor une a descrição etnográfica, o relato científico, ao estilo literário, à poesia. Em sua descrição do cotidiano das pessoas, Hubert Fichte aborda aspectos religiosos, políticos e sociológicos da vida no Brasil, do Haiti e de Trinidad. Seu enfoque difere daquele de um texto etnográfico convencional, pois os dados científicos observados não são apresentados com a objetividade rigorosa do método exigido e aplicado à ciência. O relato de Fichte transcende tais barreiras e vai em busca de um campo mais amplo de expressão, em que o autor deixa entrever sua subjetividade, colocando suas impressões, revelandose ao leitor. O relato etnográfico revela-se como um processo dialético, através do qual, segundo o próprio autor na obra Etnopoesia (1987: 37), "o mundo não seria concebido por mais tempo como um supermercado do qual se retiram pacotes de 250 gr.; ele não se dividiria mais em sujeitos e objetos da descrição, pessoas estigmatizadas"12.

Suas viagens de estudo e suas vivências em outras culturas podem ser vistas como uma busca de si mesmo, uma jornada interior em direção à alteridade, para um resgate da identidade pessoal, ao mesmo tempo em que dá voz a uma camada marginalizada da sociedade, resgatando sua importância, como no caso dos participantes da religião afro-brasileira pesquisada, o candomblé, e denunciando as injustiças sociais e a repressão política na sociedade brasileira da época. Esse ato se revela na definição da divindade iorubá que dá título à obra: Xangô, deus da chuva, do trovão e do relâmpago, e também da justiça. Ao longo da obra Xangô, encontramos

\footnotetext{
12 FICHTE, H. Etnopoesia. Antropologia poética das religiões afroamericanas. Organização e prefácio de Wolfgang Bader. Seleção de Hubert Fichte e Wolfgang Bader. Tradução de Cristina Alberts e Reny Hernandes. São Paulo: Brasiliense, 1987.
} 
passagens intercaladas sobre a violência, desigualdades sociais, miséria, futebol e opressão pela ditadura militar, que soam como uma forma de denúncia. O trecho apresentado abaixo ilustra essa posição assumida pelo autor. Nele é narrado o estilo de vida do comunista em contraste com a sua ideologia, finalizando com uma breve, mas contundente observação sobre a entrada de serviço em prédios brasileiros, que se tornou um símbolo de segregação social:

Eu sou anunciado ao conhecido comunista.

Ele esteve na prisão por motivos políticos na sua juventude.

Ele exprime ainda palavras duras sobre a miséria na cidade.

Ele habita um belo, fresco terreno sobre um morro nas proximidades do mar.

Árvores tropicais brotam de um jardim bem cuidado.

Bonitos azulejos estão assentados no muro externo.

Sobre bonitos azulejos está escrito o aviso ao lado da porta de entrada, sobre uma segunda porta:

- Entrada de serviço. ${ }^{13}$

Ou na cena na feira, em que descreve os policiais fazendo suas compras de um modo muito peculiar e transfere ao leitor as reflexões e conclusões acerca do desfecho do fato:

Leonore observa no mercado os policiais militares.

Eles vão de uma barraca a outra e escolhem frutas sem defeito e as colocam no saco.

Eles não pagam. ${ }^{14}$

A prática religiosa desempenha uma função social, pois representa uma forma de protesto de um povo oprimido politicamente e pela pobreza, uma fuga das dificuldades proporcionada pelo elemento mágico. Ela oferece uma certa forma de poder e sugere o vínculo com um mundo melhor. Sobre o tema encontram-se igualmente passagens que contém uma crítica implícita:

\footnotetext{
${ }^{13}$ Ich werde bei dem bekannten Kommunisten angemeldet.

Er hat aus politischen Gründen in seiner Jugend im Gefängnis gesessen.

Er äussert noch immer harte Worte über das Elend in der Stadt.

Er bewohnt ein schönes, kühles Grundstück auf einem Hügel in Meernähe.

Tropische Bäume quellen aus einem gepflegten Garten.

Hübsche Kacheln sind an der Aussenmauer angebracht.

Auf hübschen Kacheln steht neben der Eingangstür der Hinweis auf eine zweite Tür:

-Dienstboteneingang. (FICHTE, 1976: 24)

${ }^{14}$ Leonore beobachtet auf dem Markt die Militärpolizisten.

Sie gehen von einem Stand zum anderen und wählen makellose Früchte aus und sacken sie ein.

Sie bezahlen nicht. (FICHTE, 1976: 15)
} 
Uma última vez à Professora DonaTheresa.

A pequena epiléptica, o deus Omulu, trabalha ainda

na cozinha para pagar as dívidas da iniciação.

- Está melhor dos seus ataques?

- Muito melhor.

- Você pode agora ir à escola como os outros?

A menina não responde e continua esfregando. ${ }^{15}$

Em sua palestra "O Direito à Literatura", ANTONIO CANDIDO (2004: 182) aponta alguns papéis desempenhados pela literatura. Há, por exemplo, o aspecto estético, humanizador, em que a estrutura elaborada da obra literária apresenta um modelo de coerência gerado pela força da palavra, o que permite ao leitor ordenar a própria mente e sentimentos e, por conseguinte, organizar melhor sua visão do mundo. Cumprindo outra função, existem produções literárias em que o autor exprime suas convicções ou manifesta parte de uma determinada visão da realidade num tom crítico. Essa tomada de posição analisa a realidade social e pretende restaurar o equilíbrio nas situações de desigualdade através da literatura. Retomando os trechos de Xangô citados acima, entendemos a literatura de Hubert Fichte, em especial as obras dedicadas às religiões afro-americanas, como manifestação crítica dos fatos vistos e vivenciados. Trata-se de uma "literatura comprometida" ou "compromisso literário", e não de um poder imposto de cima para baixo, ou de um autor que faz política em sua obra, como AGUIAR E SILVA (1976: 119) distingue a seguir:

Torna-se necessário efetuar uma distinção nítida entre literatura comprometida ou, para usar um vocábulo francês muito em moda, literatura "engagée", e literatura planificada ou dirigida. Na literatura comprometida, a defesa de determinados valores morais, políticos e sociais nasce de uma decisão livre do escritor; na literatura planificada, os valores a defender e a exaltar e os objetivos a atingir são impostos coativamente por um poder alheio ao escritor, quase sempre um poder político, com o consequente cerceamento, ou até aniquilação, da liberdade do artista.

Aguiar e Silva ressalta ainda a importância do termo compromisso e sua ligação com as filosofias existencialistas. Remete-nos a Heidegger ${ }^{16}$, para o qual o homem não é um receptáculo passivo que recolhe dados no mundo, mas o homem é um ser-

\footnotetext{
${ }^{15}$ Ein letztes Mal zu Professora Dona Theresa.

Die kleine Epileptikerin, der Gott Omolu, arbeitet noch immer

in der Küche die Einweihungsschulden ab.

-Geht es besser mit deinen Anfällen?

-Viel besser.

-Kannst du jetzt in die Schule gehen wie die anderen?

Das Mädchen antwortet nicht und schrubbt weiter. (FICHTE, 1976: 116)

${ }^{16}$ HEIDEGGER, M. Ser e Tempo: parte II. 2ª̣ed. Trad. Márcia de Sá Cavalcanti. Petrópolis: Vozes, 1998.
} 
no-mundo, não na acepção espacial e física de estar em, porém como presença ativa, de estar em relação fundadora, constitutiva com o mundo. Aguiar e Silva aponta ainda para a influência dessa filosofia sobre SARTRE (2006 [1948]: 20), que se pode verificar em seu ensaio "O que é literatura?", documento relevante sobre o compromisso da literatura:

O escritor "engajado" sabe que a palavra é ação: sabe que desvendar é mudar e que não se pode desvendar senão tencionando mudar. Ele abandonou o sonho impossível de fazer uma pintura imparcial da Sociedade e da condição humana. O homem é o ser em face de quem nenhum outro ser pode manter a imparcialidade - nem mesmo Deus.

A postura de engamento de Hubert Fichte não se limita ao conteúdo político, ou seja, de escolhas e posicionamentos em sua obra. Essa tomada de posição se reflete igualmente na construção linguística de sua obra, como veremos a seguir.

\subsubsection{Construção linguística da obra}

A obra eleita como corpus de nossa pesquisa não segue uma narrativa linear, é composta de apontamentos colhidos em pesquisa de campo sobre a religião afro-brasileira do candomblé, entrevistas com pais e mães de santo e pesquisadores da religião, como Pierre Verger, observações da realidade social brasileira na Bahia, descrições de recortes da vida cotidiana que se assemelham a fotorreportagens, como se complementassem o registro fotográfico realizado por sua amiga e companheira de viagem, Leonore Mau (1916-2013), responsável pela da versão fotográfica do relato de viagem da obra Xangô.

Segundo Teichert (1987: 252), a organização do texto de Fichte segue um plano estrutural rígido, da primeira à última palavra. O leitor não somente participa da experiência de viagem de Fichte, mas também de um processo de conhecimento que o autor demonstra de forma argumentativo-poética. Os textos são, portanto, organizados de forma aberta, confrontando o leitor com um novo início a cada mudança de parágrafo. É justamente nessa forma fragmentária calculada que se realiza o entendimento e/ou conhecimento (Erkenntnis) sobre a experiência vivida pelo autor. O leitor quase não percebe que é conduzido e orientado por essa composição do texto, que causa estranheza e exige muito do receptor. Não há uma sequência narrativa coerente. $O$ estilo de frases curtas e, por vezes, justapostas, em 
que cada oração começa em outra linha tem a aparência de uma série de disparates que, no entanto, subjazem a um estilo arquitetônico textual. Os diversos temas tratados nas reportagens formam, por fim, um quadro que fornece informação sobre os interesses principais de Fichte, como se pode verificar no seguinte trecho de Xangô (1986: 8):

O Liftboy do hotel tem 16 anos.

Ele trabalha seis horas por dia e ganha 60 cruzeiros, 40 marcos por mês. Ele não recebe comida no hotel.

Ele tem fome.

O estilo direto é produto de uma técnica poética empregada, possui um significado, uma função, serve para expor e transportar fatos de uma forma contundente, que leva à reflexão.

A mescla da linguagem da investigação etnológica com a linguagem subjetiva utilizada por Fichte sobre suas impressões nas obras dedicadas à temática das religiões afro-americanas deflagrou uma discussão entre os críticos quanto à rotulagem, na época da publicação de ambos os volumes de Xangô, em 1976, como relata FISCH (2000: 162). Hans-Jürgen Heinrichs faz referência aos etnólogos Georges Devereux e Michel Leiris e sugere a designação "ethno-esthétique", que mais tarde se transformou no termo alemão "Ethnopoesie" (etnopoesia). Essa expressão causou em Fichte um desconforto, segundo observa TORSTEN TEICHERT (1987), pois a palavra evocava uma ideia errônea se comparada a "etnomedicina" ou "etnomúsica". Afinal, Hubert Fichte não pretendia reproduzir as palavras de povos estrangeiros; essa tarefa era cumprida pela poesia produzida por esses povos. Foi Helmut Heißenbüttel quem lançou como sugestão o termo "Poética Antropológica", que continha duas vantagens: por um lado passa a mensagem da realização de uma pesquisa poético-científica, por outro, define o homem como objeto dessa pesquisa. A "Poética Antropológica" de Fichte foi formulada por HEıßENBÜTTEL (1976) da seguinte forma:

[...] seu acesso aos fatos e contextos das formas de manifestação etnológicas e religiosas nas áreas em que ele adquiriu experiência [...] é mais direto que o de muitos cientistas. E quando, nessa pesquisa e descrição das camadas da realidade interna do ser humano, pode-se 
identificar uma nova definição antropológica, então a sua antropologia é a mais concreta, por ser poética. ${ }^{17}$

A centralidade que ocupa a linguagem na obra de Fichte é abordada por BADER (1987), que considera Fichte arqueólogo da linguagem, que junta seu material na forma adequada como um artesão, transformando coisas, pessoas e acontecimentos em palavras e figuras de linguagem. Bader ainda compara o autor alemão com o pintor italiano Arcimboldo (1527 - 1593), que constrói o rosto de um bibliotecário com livros, e o de um hortelão com legumes:

[...] assim Fichte compõe o espelho da realidade como um quadro linguístico de palavras e composição de palavras. O resultado é [...] uma composição aberta, não unívoca, surpreendente, múltipla, que dá ao leitor a liberdade de entrelaçar e ligar: partículas da realidade são constantemente desfeitas e associativamente combinadas., lugares, pessoas e épocas são montados diretamente lado a lado, percepções do autor misturam-se a experiências autênticas dos protagonistas. Tudo isto envolto num culto da palavra extremamente virtuosístico, que, na sua mistura de jogos de palavras, enfileiramento de frases, citações, fetichizações de nomes, arranjos cênicos, entrevistas inseridas, prosa científica, etc. se serve de toda a palheta dos meios retóricos (1987: 19)

Sobre seu acesso sui generis à ciência tradicional, FICHTE (1987: 29) se coloca quanto à importância da palavra como modo de comportamento, como representação de suas ações no meio social e da interação com o seu entorno:

A antropologia, a etnologia, a etologia e as ciências afins constituem formas distintas de tratamentos dos modos de comportamento do ser humano.

Por logos entende-se, principalmente, "a palavra".

Palavras são modos de comportamento.

E quando questiona as razões de o etnólogo rejeitar suas possibilidades estéticas, defende a capacidade dinâmica e de movimento da expressão poética, que confere força transformadora na dialética entre o fato e sua formulação linguística: "A linguagem poética, ao contrário da linguagem tática da propaganda e da política, se

\footnotetext{
${ }^{17}$ [...] sein Zugang zu den Fakten und Zusammenhängen ethnologischer und religiöser Erscheinungsformen in den Bereichen, in denen er seine Erfahrungen gesammelt hat [...], sei unmittelbarer als der vieler Wissenschaftler. Und wenn in dieser Erforschung und Beschreibung von Schichten der inneren Realität des Menschen - eine neue anthropologische Definition abzulesen sei, so sei seine Anthropologie die konkretere, weil poetische.

HEIBENBÜTTEL, Helmut. Vaudou als Reise nach innen. Hubert Fichte und Leonore Mau über afroamerikanische Religionen - Bahia, Haiti, Trinidad. In: Die Zeit. 8.10/1976
} 
renova no instante em que se configura como enunciado, juntamente com o objeto desse mesmo enunciado" (ibid.: 37).

AlCÂNTARA (1991), em seu artigo "A etnopoesia de Hubert Fichte", discute também essa relação entre a pesquisa científica expressa através da linguagem e esclarece que de início faz-se necessário entender o que o próprio Fichte entende por etnopoesia e esclarecer qual a relação deste termo com a antropologia. No desmembramento da palavra composta, procuramos esmiuçar esses conceitos individualmente. O componente etno-, ou seja, a pesquisa etnológica ou o relato etnográfico, remete tradicionalmente à linguagem que requer a neutralidade do discurso da ciência e cobra do pesquisador posturas e atitudes objetivas, em que não cabem interpretações ou impressões sobre o fato observado, estudado e relatado. Como bem destaca Alcântara, Fichte faz uso da antropologia, mas seu texto se diferencia formalmente da prosa científica. Assim, o próprio Fichte afirma: "O que aprendi com a etnologia? O hábito incômodo da verificação". Em outras palavras, ele se apropriou de alguns métodos da linguagem científica da antropologia, porém não se sujeitou às amarras do discurso de neutralidade da ciência:

\footnotetext{
Quem nos quer convencer de que o mundo só pode ser captado através de linguagens técnicas?

O que se pretende com isso?

A sujeição.

A sujeição através de uma linguagem da ciência.

(Ibid.: 31)
}

Fichte se assume como pesquisador etnográfico, mas não abre mão de fazer suas anotações de campo marcadas por uma forma de expressão que comunicasse também suas experiências pessoais e, ao mesmo tempo, o apoiasse nessa busca da compreensão de si mesmo.

\footnotetext{
Será uma vergonha confessar que se está pesquisando sobre os Wolof porque se é homossexual?

Certamente não mais!

Isso significa também um fato etnológico e seria uma informação errônea escondê-lo. (ibid, p. 33)
}

Nesse ponto, recolhemos a segunda parte da palavra "etnopoesia": -poesia como expressão de subjetividade, busca de si mesmo, liberdade para comunicar todas as 
etapas de pesquisa e escrita de interesses pessoais de modo próprio, numa narrativa não linear e em reação ao romance burguês de entretenimento, coerente com a atitude crítica de Fichte em relação aos valores da cultura europeia.

\subsection{Hubert Fichte e Leonore Mau: a documentação dupla}

Hubert Fichte conheceu Leonore Mau nos anos de 1950. Contudo, seu relacionamento amoroso só teve início mais tarde, quando ele, de volta da Provença para Hamburgo, começou a se profissionalizar como escritor.

Leonore Mau (1916 - 2013) fotografava na época para revistas de arquitetura e vivia uma vida confortável ao lado de seu marido, o arquiteto Ludwig Mau. Abdicou de tudo para formar com Fichte uma parceria de vida e de trabalho que durou até a morte do escritor. Ele sentia que ela o completava e queria transformá-la em uma fotógrafa famosa. No trabalho em comum, ela se interessava por todos os temas de Fichte, como sua participação no Grupo 47 , o submundo de St. Pauli e as culturas afroamericanas e as religiões sincretistas nos anos de 1970 e 1980. Empreendeu junto com Fichte quase todas as viagens de pesquisa, registrando com sua lente e seu olhar essas experiências, da perspectiva da fotógrafa.

Dentre suas obras em conjunto encontra-se a primeira edição de Xangô (1976), que foi acompanhada do livro fotográfico de Leonore Mau, um relato de viagem e leitura etnográfica registrado por imagens. Em um levantamento e análises feitos sobre as capas de ambos os livros, constatamos que a obra de Leonore recebeu uma capa quase idêntica à edição em texto, com exceção do nome da autora, que aparece na parte superior da capa, acima do título em vermelho, na mesma posição e forma em que apareceram o nome de Fichte, como se pode observar a seguir: 
Figura 1: capa de 1976

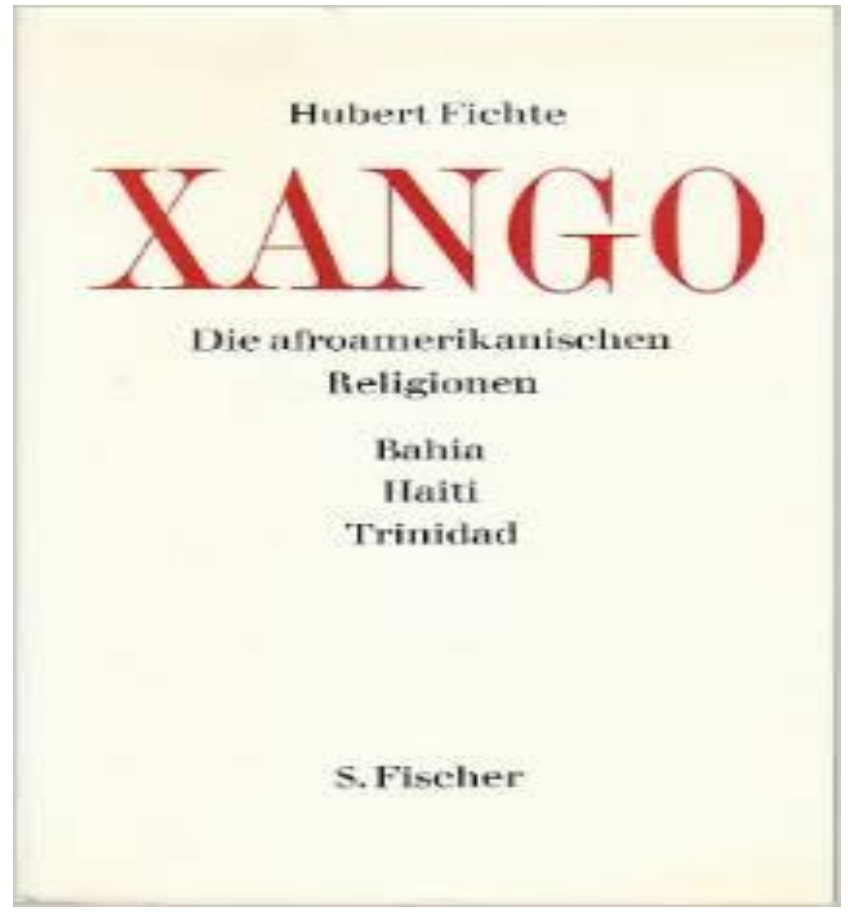

Fonte: FICHTE, Hubert. Xango. Die afroamerikanischen Religionen. Bahia. Haiti. Trinidad. Frankfurt am Main: S. Fischer, 1976.

Figura 2: livro de fotografias, 1976

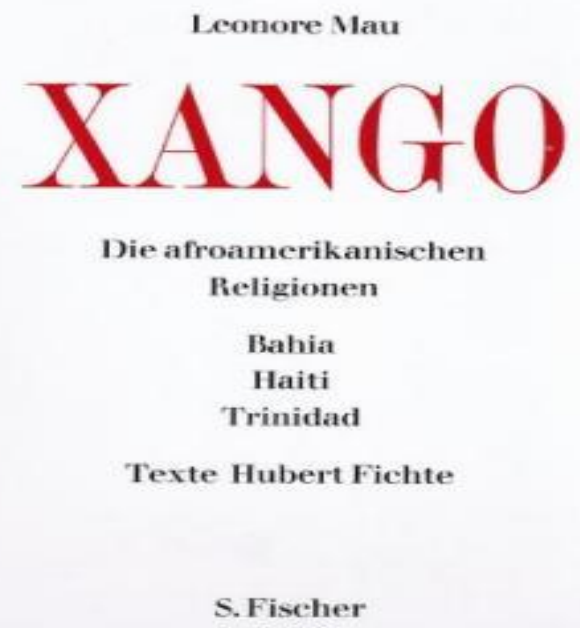

MAU, Leonore. Xango. Die afroamerikanischen Religionen. Bahia, Haiti, Trinidad. Texte Hubert Fichte (Xango. As religiões afro-americanas. Bahia. Haiti. Trindad). Frankfurt am Main: S. Fischer, 1976. 
A semelhança se explica pelo fato de ambos os trabalhos serem resultado de viagens de pesquisa e investigação das religiões afro-americanas de que tratam os textos e coexistem numa relação de complementaridade, além de pertencerem a um projeto concebido pelos autores, um registro que ele mesmo denominou de "documentação dupla", quando narra, em uma entrevista a WISCHENBART (1980: 81) sobre sua primeira experiência com as religiões sincretistas:

"[...] Eu nunca acreditei que se pudesse, como branco, participar de tais ritos. Esse foi, aliás, o primeiro passo, quando os fiéis dessa religião disseram: "sim, por que vocês não vêm?" E um próximo, muito importante passo foi que Leonore Mau, minha mulher, soube, por uma mistura de impertinência e discrição, tirar fotos, tirar fotos para ela artisticamente satisfatórias. Quando isso se tornou uma experiência, eu pensei que se tivesse realmente a possibilidade de uma documentação dupla, que nunca existiu antes no mundo. ${ }^{18}$

BRAUN (1997), em sua discussão sobre a essa obra de documentação dupla, única em sua envergadura na história da literatura e da fotografia, afirma que na recepção de Fichte ela ainda não mereceu a atenção devida. Segundo ele, um dos motivos é porque tais obras não se encontram completamente catalogadas e reunidas. Mesmo em instituições de divulgação de literatura, em que a obra fotográfica de Leonore Mau pôde ser incluída, ela aparece à margem. Também em suplementos literários e resenhas sobre os volumes Xangô e Petersilie (Salsinha), os livros fotográficos mal são mencionados. Braun aponta inclusive para obras de teóricos que tratam de textos etnopoéticos de Fichte, como Davi Simo, que considera os textos como livros independentes das fotografias e que essas sozinhas contam pouco sobre as religiões afro-americanas. Braun critica tal opinião e a atribui ao domínio da cultura da escrita como expressão máxima da racionalidade, que relega a imagem a um papel subordinado e desvalorizado. Enfatiza ainda a importância de se evitar uma hierarquização de ambas as linguagens. A conservação de sua autonomia tem como objetivo a condução e sedução do leitor observador e do observador leitor para lançar

\footnotetext{
${ }^{18}[$ [...] Ich hatte nie geglaubt, daß man als Weißer an solchen Riten teilnehmen könnte. Das war überhaupt der erste Schritt, als Gläubige dieser Religion sagten: >ja, warum kommen sie nicht?< Und ein nächster, sehr wichtiger Schritt war, da $\beta$ Leonore Mau, meine Frau, es verstanden hat, durch eine Mischung aus Impertinenz und Diskretion Fotos zu machen, für sie artistisch befriedigende Fotos zu machen. Als das eine Erfahrung geworden war, dachte ich einmal daran, da $\beta$ man tatsächlich die Möglichkeit einer doppelten Dokumentation hätte, die já vorher auf der Welt nicht bestanden hat.
} 
um olhar equilibrado a esses dois meios de expressão, como narra Fichte em seu romance Explosion. Roman der Ethnologie (Explosão. Romance da Etnologia, 2006: 191):

\begin{abstract}
Jäcki e Irma estavam à procura de um banho de sangue.
Para Irma era, principalmente, uma questão de iluminação, Distância focal e velocidade, para Jäcki era uma questão de construção de frases. ${ }^{19}$
\end{abstract}

No volume fotográfico Xangô, merece destaque a foto que descreve o ritual do banho de sangue na iniciação do candomblé. Leonore Mau e Hubert Fichte consideravam esse ritual o centro esotérico dessa religião afro-americana. A publicação dessas fotos causaria um grande efeito na Alemanha, fato relevante, pois o escritor e a fotógrafa dependiam do sucesso de seu trabalho para financiar suas viagens de pesquisa da cultura e da religião. A imagem escolhida pertence à série fotográfica que descreve o bori, um ritual de pré-iniciação no candomblé. No livro fotográfico ela ocupa duas páginas (p. 44 - 45) sem margens. A foto foi tirada com uma lente objetiva grande angular, que serve para inserir um objeto ou pessoa em seu contexto. Nesse caso, um grupo de pessoas é alterado em sua proporção. Eles formam um círculo em volta de um homem jovem que está sentado no meio e parecem atraídos por essa força central (BRAUN, 1997). Dois homens e uma mulher seguram sobre sua cabeça uma galinha d'angola imolada. O iniciado está com os olhos fechados, apresentando um ar de reverência e profunda concentração, por sua face escorre o sangue do animal. Uma nota sobre a cerimônia encontra-se registrada na seção de legendas do livro fotográfico de Leonore Mau, Xangô, no trecho em alemão a seguir:

44,45 O banho de sangue na noite antes da cerimônia do nome. $\mathrm{O}$ noviço é consagrado à divindade que se manifestou nele através do transe. Os animais sacrificados que correspondem a essa divindade são abatidos sobre a cabeça do noviço. (Mau, 1976: 168) 20

\footnotetext{
19 Jäcki und Irma waren auf der Suche nach dem Blutbad.

Für Irma war es eine Angelegenheit von Belichtung,

Brennweite und Geschwindigkeit, für Jäcki eine Angelegenheit des Satzbaus.

${ }^{20}$ 44,45 Das Blutbad in der Nacht vor der Namenszeremonie. Der Novize ist jener Gottheit geweiht, die sich in ihm durch Trancen manifestiert. Die dieser Gottheit zugeordneten Opfertiere werden über den Kopf des Novizen geschlachtet. (Mau, 1976: 168)
} 
A cerimônia do banho de sangue, Bori ou lbori, é a grande iniciação dessa religião, imprescindível ao neófito antes do ritual de raspagem da cabeça, que o habilita mais tarde ao sacerdócio. O termo compõe-se da fusão de Bó, oferenda em iorubá, com Ori, que significa cabeça, em tradução literal quer dizer, portanto, oferenda à cabeça. Segundo a doutrina, cada pessoa escolhe seu Ori antes de nascer, ou seja, seu princípio individual, suas potencialidades. ${ }^{21}$

Em suas pesquisas, Fichte reconheceu a importância de se fotografar um banho de sangue e o difícil acesso a esse ritual do candomblé baiano, como revela em duas passagens de Xangô (1976):

Sr. R., o proprietário da grande loja de fotografia na praça, que danifica por inveja os filmes dos colegas, pagou 1.600 dólares para fotografar o banho de sangue em um Candomblé. (1976: 28) ${ }^{22}$

Ou ainda no seguinte trecho: "O Fulano de Tal deve ter se vendido por 2.000 dólares para deixar fotografar o banho de sangue."23 (1976: 29)

Figura 3: banho de sangue

\footnotetext{
${ }^{21}$ Disponível em: https://ocandomble.wordpress.com/2008/05/26/bori/. Acesso em 3 nov. 2016.

22 Herr R., der Besitzer des grössten Fotogeschäftes am Platz, der den Kollegen aus Neid die Filme beschädigt, hat 1600 Dollar bezahlt, um das Blutbad in einem Candomblé zu fotografieren.

${ }^{23}$ Der Soundso soll sich für 2000 Dollar hergegeben haben, das Blutbad zu fotografieren zu lassen.
} 


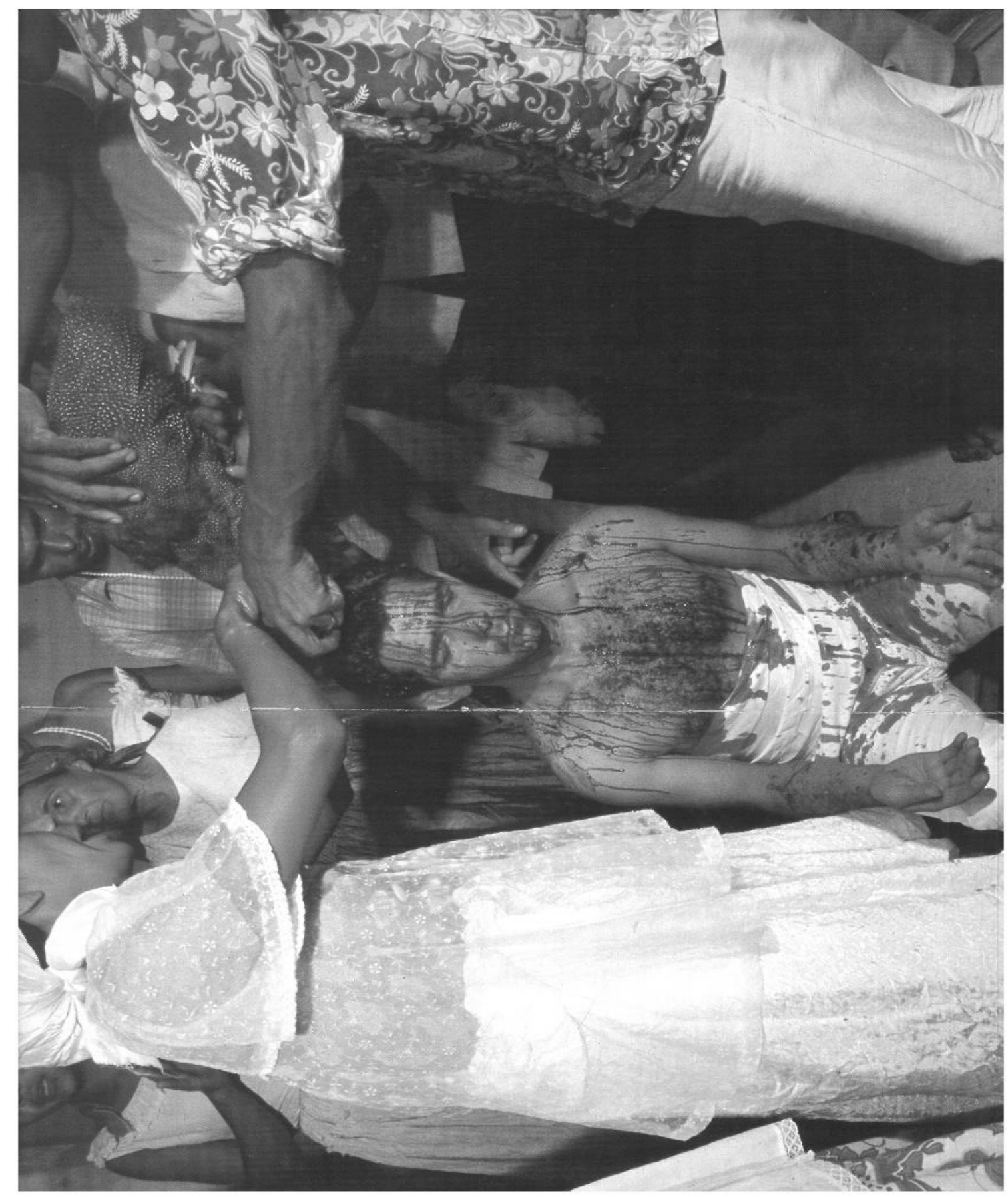

Fonte: MAU, Leonore. Xango. Die afroamerikanischen Religionen. Bahia, Haiti, Trinidad. Texte Hubert Fichte (Xango. As religiões afro-americanas. Bahia. Haiti. Trindad). Frankfurt am Main: S. Fischer, 1976.

É importante mencionar ainda que, em contraposição à singeleza das capas descritas acima, a S. Fischer Verlag lançou em 1984 uma nova edição de Xangô, cuja ilustração na capa contempla as funções desse elemento peritextual, ou seja, atrair a atenção do leitor de forma dramática, chamativa e espetacular. Ela exibe 
uma foto do projeto do livro fotográfico de Leonore Mau já citado, homônimo à obra de Fichte. A imagem escolhida pertence à série fotográfica que descreve o bori.

Figura 4: capa de 1984

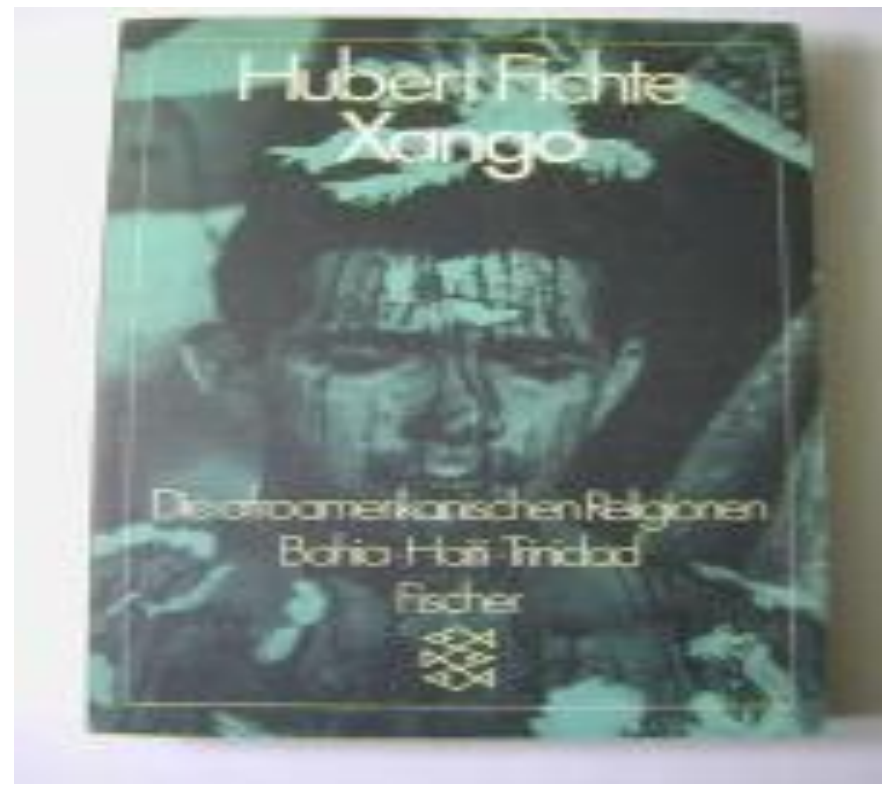

Fonte: FICHTE, Hubert. Xango. Die afroamerikanischen Religionen. Bahia. Haiti. Trinidad. Frankfurt am Main: S. Fischer, 1984.

A breve análise do material fotográfico produzido por Leonore Mau para o registro de imagens de Xangô nos oferece oportunidade para tecer algumas considerações sobre o olhar fotográfico de Fichte em suas obras. Sua técnica de escrita em forma de fragmentos que retratam com precisão e economia o momento vivenciado e observado revela a influência da fotografia, arte que ficou conhecendo melhor com Leonore, e que marcou sua maneira de produzir textos. No início de sua carreira literária, Fichte produziu colagens de fotos para acompanhar a edição de sua peça de teatro Ödipus auf Håknäss (1961). Em seu espólio, que se encontra guardado na Biblioteca Estadual de Hamburgo, encontram-se 40 reproduções fotográficas das colagens do autor, fotografadas por Leonore Mau.

Essa experiência de trabalho com imagens estendeu-se também para o cinema, como na realização do fotofilme do ano de 1966, Der Tag eines unständigen Hafenarbeiters ( $\mathrm{O}$ dia de um trabalhador portuário temporário). 
Nessa categoria de reportagem cinematográfica, uma série de fotografias é projetada, permanece alguns segundos na tela e é novamente retirada. Como leitora, percebo grande semelhança entre o texto traduzido nesta dissertação com essa forma de manifestação estética. Já em sua disposição gráfica, aparecem em blocos textuais apresentados com muito realismo. Transmitem, num primeiro olhar, a impressão de quadros isolados, mas numa leitura mais atenta, nota-se que são cortes calculados e construídos pelo autor. Trata-se de uma trama aparentemente desconexa, mas que em sua concepção é unida por um fio exigente, que requer vontade e esforço do leitor. Entretanto, tendo-se formado a teia, adquire um significado maior dentro do seu momento sóciohistórico, como aponta SCHøLLHAMMER (2007:21) 24, ao discutir a afinidade entre cinema e literatura:

O paradoxo da representação cinematográfica consiste em dar concretude à fragmentação do mundo moderno e, simultaneamente, oferecer uma unidade material e sensível a um tecido singular de ligações entre acontecimentos, capaz de produzir afinidades entre as experiências múltiplas que maneja.

As reflexões apresentadas nessa seção do capítulo serão retomadas nos comentários sobre as notas de tradução, sobretudo no que diz respeito à participação de Leonore Mau e sua câmera Hasselblad nas pesquisas de Fichte sobre o candomblé,

${ }^{24}$ SCHøLLHAMMER, Karl Erik. Além do visível: o olhar da literatura. Rio de Janeiro: 7Letras, 2007. 


\section{CAPÍTULO II}

\section{Sobre a moldura teórica e a estratégia de tradução}

$\mathrm{Na}$ área de Estudos da Tradução, escolhemos como ancoragem teórica para a nossa pesquisa os teóricos da tradução Friedrich Schleiermacher, cujo texto seminal sobre duas estratégias de tradução, uma estrangeirizante e a outra facilitadora, influenciou e ganhou uma releitura na atualidade pelos teóricos da tradução Antoine Berman e Lawrence Venuti. André Lefevere, com seus conceitos de recriação e patronagem, também ofereceu significativa contribuição para as reflexões quanto à divulgação e publicação de uma tradução comentada, produzida inicialmente para o meio acadêmico. Além disso, buscamos respaldo nas ideias de Christiane Nord sobre funcionalismo e lealdade em tradução, cuja aplicação garante inteligibilidade a uma tradução com forte tendência estrangeirizante, que foi o caminho que elegemos.

Quanto aos caminhos que o tradutor deve seguir para unir escritor e leitor, Schleiermacher (2010 [1813]) propõe em seu ensaio Über die verschiedenen Methoden des Übersetzens (Sobre os diferentes Métodos de Tradução), publicado na Alemanha em 1838, duas alternativas tradutórias: "Ou bem o tradutor deixa o escritor o mais tranquilo possível e faz com que o leitor vá a seu encontro, ou bem deixa o mais tranquilo possível o leitor e faz com que o escritor vá a seu encontro" (SCHLEIERMACHER, 2010 [1813]: 58)..$^{25}$

Por um lado, trata-se de uma tradução distanciadora, que quer transmitir ao leitor a mesma imagem e impressão que o tradutor, conhecedor da língua do texto escrito na língua de partida, percebeu da obra, não apagando seus traços originais. Pode causar estranhamento no seu leitor, entretanto contribui para the apresentar o Estrangeiro sem facilitação. Do outro lado estaria a tradução aproximadora ou assimiladora, na qual o autor é trazido diretamente para o mundo do

\footnotetext{
${ }^{25}$ SCHLEIERMACHER, Friedrich. "Über die verschiedenen Methoden des Übersetzens/Sobre os diferentes Métodos de Tradução". In: Clássicos da Teoria da Tradução. Antologia Bilíngue. Vol. 1. Alemão Português. Werner Heidermann (Org.). Florianópolis: UFSC/Nuplitt, 2010, p. 38-101. Tradução de Celso R. Braida
} 
leitor e este último tem a impressão de estar lendo um texto produzido em sua língua materna e cultura de origem.

O autor alemão ainda ressalta que os dois caminhos expostos acima são tão diferentes entre si que se deve escolher apenas um deles e segui-lo com bastante exatidão e coerência para produzir um resultado satisfatório. Schleiermacher segue analisando os dois métodos e aponta-nos suas vantagens e desvantagens, bem como os limites em que podem ser aplicados. Nesse sentido, alerta aos tradutores que optam pelo estilo de tradução que mais se aproxima do original, que exige uma atitude tradutória não cotidiana, ou seja, que contrarie o que se espera normalmente naquele contexto específico, que esse caminho oferece perigos ao profissional que se esforça para manter exótico o tom da língua, acrescentando que esse método pode ser criticado por não ser espontâneo e gerar apenas uma semelhança exótica, sendo, portanto, um desafio a ser vencido pelo tradutor. Tem, pois, que ser exercido com arte e medida, sem causar prejuízo próprio e qualquer dano à língua. No trecho a seguir, Schleiermacher (2010: 71) ilustra essas dificuldades com algumas metáforas:

Quem não deseja apresentar sempre sua língua materna com a
beleza mais castiça que possa se dar em cada gênero? Quem não
prefere engendrar filhos que mostrem genuinamente a linhagem
paterna, ao invés de mestiços? Quem se aplicará com gosto a
executar em público movimentos menos soltos e elegantes do que
sem dúvida poderia e, pelo menos às vezes, parecer rude e travado,
a fim de parecer ao leitor bastante estranho para que este não perca
de vista as circunstâncias? Quem admitirá de boa vontade que o
considerem torpe, enquanto se esforça por conservar frente a língua
estranha toda a proximidade que tolera à própria, e que se Ihe
censure como aos pais que entregam seus filhos a treinadores,
porque, em vez de exercitar a sua língua materna em uma ginástica
apropriada, trata de acostumá-la a contorções estranhas e
antinaturais?

$\mathrm{Na}$ aplicação do método estrangeirizante de traduzir, deve-se estar preparado pois, de acordo com esse autor, para o fato de que o trabalho talvez não alcance a aprovação geral. Cabe ao tradutor, então, agir com sabedoria, desenvolvendo critérios sobre que aspectos da tradução devem ser destacados e quais atenuados. Ele afirma ainda que para o sucesso do método devem ser cumpridas ainda duas condições: que a compreensão de obras estrangeiras seja uma situação conhecida e desejada, e que se conceda certa flexibilidade à língua nacional. Se forem cumpridas tais condições, esse modo de traduzir "chega a ser um fenômeno 
natural, intervindo no processo total da cultura e, ao alcançar um valor determinado, proporciona, por sua vez, um prazer seguro" (ibid.: 77).

$\mathrm{Na}$ tradução em questão, em torno da qual iremos desenvolver nossa dissertação, adotamos o primeiro método proposto por Schleiermacher, o de aproximação do leitor da cultura, da obra e do autor estrangeiros. Estamos cientes, no entanto, de que devemos agir com coerência e sabedoria nessa tarefa. A coerência consiste em praticar até o final essa proposta de manutenção do tom causador de estranhamento, o que confere visibilidade ao tradutor. A sabedoria será aplicada com o uso do equilíbrio, evitando o efeito "rude e travado" e sempre cuidando para que o texto seja inteligível e que o leitor não perca a noção das circunstâncias.

Schleiermacher prestou muitas outras contribuições à tradução além das máximas citadas e discutidas acima. No presente capítulo foi feito apenas um recorte do conteúdo que serviu como reflexão para os estudos da tradução nos séculos XX e XXI.

Suas colocações sobre (in)visibilidade do tradutor foram desenvolvidas e discutidas mais tarde, no séc. XX por Lawrence Venuti, sob um viés político. Segundo MARTINS (2010), o teórico acrescenta um componente ideológico às duas alternativas tradutórias e as chama de estrangeirização, que seria correspondente ao distanciamento, e domesticação, que aproxima o leitor do autor pelo método da fluência, pela qual o tradutor realiza um trabalho de aculturação que domestica o texto estrangeiro, tornando-o acessível, e familiar para o leitor do texto traduzido, levando-o a reconhecer a sua própria cultura em um texto oriundo de um outro ambiente cultural. Essa teoria serve de base para o desenvolvimento de sua ideia de invisibilidade do tradutor, relacionada a dois fenômenos que se influenciam reciprocamente: por um lado, o tradutor manipula a língua de chegada, o que pode criar no leitor a impressão de que o texto traduzido foi na realidade escrito na língua meta; por outro, gera-se um critério de avaliação da tradução que a considera boa somente quando a leitura é fluente, isto é,

(...) quando a ausência de peculiaridades linguísticas ou estilísticas a faz parecer transparente, dando a impressão de refletir a personalidade ou a intenção do autor estrangeiro ou a essência do sentido do texto de partida" (VENUTI apud MARTINS, 2010: 66). 
Isso daria a impressão de não se tratar de uma tradução, mas sim do texto "original", o que tornaria o texto de chegada fluente e o tradutor invisível. Ainda de acordo com MARTINS (2010), Venuti apresenta como características do texto fluente, no caso do inglês, uma sintaxe linear, sentido unívoco (ou ambiguidade controlada), uma linguagem atual e padrão, evita, por exemplo, polissemia, arcaísmos, gírias, jargões, mudanças abruptas de tom ou dicção.

O termo "invisibilidade", desenvolvido por Venuti em seu livro The Translator's Invisibility. A history of translation. (1995) serviu originalmente para descrever a situação do tradutor e sua atividade na cultura anglo-americana contemporânea. Ele nos remete a dois fenômenos determinantes: o efeito ilusório do discurso do tradutor e a prática de leitura e avaliação no Reino Unido e nos Estados Unidos da América. Desse modo, explica que

Um texto traduzido, seja de prosa ou poesia, ficção ou não-ficção, é considerado aceitável pela maioria dos editores, revisores e leitores quando sua leitura é fluente, quando a ausência de quaisquer peculiaridades linguísticas ou estilísticas o faz parecer transparente, dando a aparência de que ele reflete a personalidade do escritor estrangeiro ou a intenção ou o significado essencial do texto estrangeiro - a aparência, em outras palavras, de que a tradução não é, na realidade, uma tradução, mas o "original". (1995: 1$)^{26}$

O fato destacado por esse teórico é que o efeito ilusório de transparência e discurso fluente esconde várias circunstâncias em que a tradução é realizada. A primeira é a intervenção do tradutor no texto de partida: quanto mais fluente for a tradução, mais invisível se torna o tradutor. Mas o conceito de invisibilidade abarca também uma crítica cultural da dominação global angloamericana que limita o número de textos a serem traduzidos para o inglês e os submete a uma revisão de domesticação. Com sua teoria, o autor estadunidense pretende tornar o tradutor mais visível e mudar as condições da teoria e da prática da tradução atualmente, lutar contra o etnocentrismo, racismo, imperialismo e narcisismo cultural, ou seja, reconhecer sua própria cultura no texto estrangeiro. Por outro lado, na direção centro-periferia, ele aponta a enorme influência que obras traduzidas

\footnotetext{
${ }^{26}$ A translated text, whether prose or poetry, fiction or nonfiction, is judged acceptable by most publishers, reviewers, and readers when it reads fluently, when the absence of any linguistic or stylistic peculiarities makes it seem transparent, giving the appearance that it reflects the foreign writer's personality or intention or the essential meaning of the foreign text-the appearance, in other words, that the translation is not in fact a translation, but the "original."
} 
exercem na formação de identidades nacionais em culturas estrangeiras, auxiliando a dominância cultural e ideológica.

Em outro momento, Venuti ainda rebate o julgamento de traduções pelo conceito matemático de equivalência semântica, pois o significado é uma relação plural e contingente, e não algo imutável. Elucida ainda que a tradução da corrente de significantes do texto da língua-fonte é substituída por outra na língua de chegada e o tradutor é o responsável por lhe conferir força e interpretação. O significado depende da relação e diferenças entre os significantes e de outros fatores como polissemia e intertextualidade. Ambos os textos implicados na tradução consistem em diversidade linguística e material cultural que independem da ação e da vontade do escritor e do tradutor. Portanto, o processo contém várias possibilidades e escolhas interpretativas em situações sociais específicas e diferentes momentos históricos.

Diante dessas considerações, entendemos o tradutor como uma pessoa com personalidade própria, um ser social e histórico, que deve ter liberdade para empreender suas escolhas tradutórias, imprimir sua interpretação e exercer sua criatividade. Em nosso trabalho, aspiramos ao alcance da visibilidade do tradutor como definida por Venuti, assim como à visibilidade da obra traduzida, apresentando o modo de expressão do autor.

Outro autor que prestou contribuição valiosa aos Estudos da Tradução com suas reflexões acerca de atitudes tradutórias e do posicionamento do tradutor foi Antoine Berman, tradutor e teórico francês da tradução, que privilegia um modo de traduzir que conservaria as características da língua-fonte, a tradução da letra, e que condena o modo que domesticaria o texto estrangeiro na língua-meta, a tradução etnocêntrica (BATTISTI, 2000:11).

Em sua obra $A$ tradução e a letra ou O albergue do longínquo (2007[1985]: 16), Berman desfaz o mal-entendido provocado pela expressão "tradução literal", que segundo ele não quer dizer traduzir "palavra por palavra", o que os espanhóis chamam de "tradução servil", e elucida a diferença entre "palavra" e "letra" pela exemplificação da tradução de provérbios, que normalmente têm equivalente em outra língua: 
Assim, ao alemão "a hora da manhã tem ouro na boca" ${ }^{27}$ parece corresponder na França a "o mundo pertence aos que se levantam cedo". [...] Desta forma, frente a um provérbio estrangeiro, o tradutor encontra-se numa encruzilhada: ou busca seu suposto equivalente, ou traduz "literalmente", "palavra por palavra". É preciso também traduzir seu ritmo, o seu comprimento (ou a sua concisão), suas eventuais aliterações etc. Pois um provérbio é uma fórmula. $O$ trabalho tradutório se situa precisamente entre esses dois polos: a tradução "palavra por palavra" do provérbio alemão, que conservará "ouro", "manhã" e "boca" (que não se encontram no equivalente francês) e a tradução da forma provérbio, a qual pode eventualmente ser levada, para atingir seus fins, a forçar o francês e a modificar elementos do original.

O autor considera o caso dos provérbios bastante simbólico para esse tipo de tradução, pois procurar equivalentes, nesse caso, significa a recusa de introduzir na língua-meta toda a estranheza do provérbio original, a boca cheia de ouro do ar matinal alemão, revela também a recusa de fazer da língua que abriga a tradução o que Berman chamou de $O$ albergue do longínquo. Outra expressão por ele utilizada para esse fenômeno foi afrancesar a obra da língua de partida, seguindo a velha tradição.

Esse último termo nos remete a outro conceito desenvolvido e criticado pelo teórico francês: sua concepção de tradução etnocêntrica, que considera tudo que é externo à sua cultura, ou seja, o estrangeiro, como negativo, ou na melhor das hipóteses, bom para ser adaptado, para enriquecer essa cultura. Seguindo esse princípio, a obra deve ser traduzida dando a impressão de que o autor teria escrito daquela maneira se tivesse escrito na língua de chegada. Deve-se apagar toda marca da língua-fonte. A tradução deve ter um caráter mais normativo que a língua-meta, não deve chocar com estranhamentos lexicais e sintáticos.

Além disso, Berman discute outra modalidade tradutória tradicional, a tradução hipertextual, que consiste em imitar um outro texto, e ocorre, por exemplo, em um pastiche, uma recriação livre, uma paráfrase, uma citação, um comentário, e que do ponto de vista formal estão muito próximos da tradução. Sua crítica sobre esse tipo de modificação do texto foca-se no fato de que, na forma de tradução, pode-se recuar diante de certas particularidades do texto, mas não se deve transformar o texto

\footnotetext{
27 "Morgenstund hat Gold im Mund".
} 
nitidamente. Já que para Berman toda tradução possui algo de etnocêntrico e hipertextual, o trabalho crítico a ser feito é o de não perder de vista que o tradutor deve preservar a pura estranheza da obra estrangeira que traduz.

Berman aborda também a dimensão ética da tradução, denominada por ele de objetivo ético. Afirma que em sua área, o tradutor possui um espírito de fidelidade e exatidão, sendo essa a sua paixão, e não de natureza estética ou literária. Imbuído dessa postura ética, ele reconhece e recebe o Outro enquanto Outro. Reitera a seguir que "a tradução, com seu objetivo de fidelidade, pertence originariamente à dimensão ética". Ela é, na sua essência, animada pelo "desejo de abrir o Estrangeiro enquanto Estrangeiro ao seu próprio espaço na língua". (BERMAN, 2007: 68; grifos do autor)

A posição tradutológica de Berman definida por ele como tradução à letra que acabamos de explanar acima, encontra no aspecto da postura ética uma afinidade com a tipologia funcional de tradução literal desenvolvida por Christiane Nord, como exporemos a seguir.

ChRISTIANE NORD (1989: 103, 105), em sua tipologia funcional referente às formas documentais de tradução, subdivide-as em quatro tipos: a tradução palavra por palavra, a tradução literal, a tradução filológica e a tradução exotizante. Para a nossa discussão, destacamos duas modalidades: a tradução literal (wörtliche Übersetzung ou grammar translation), na qual a formação de estruturas sintáticas da língua-fonte é substituída por estruturas de mesmo significado na língua de chegada (transposição obrigatória). Trata-se de eleger estratégias tradutórias que contemplem a lealdade ao texto de partida, conservando seus traços funcionais relevantes, preocupando-se também com o leitor do texto de chegada, ou seja, apresentar um texto claro e compreensível, unindo o alheamento às características de inteligibilidade.

Em seu artigo "Loyalty revisited. Bible translation as a case point" (2001), Nord elucida que sua abordagem de tradução se apoia em dois pilares: o funcionalismo, cujo objetivo é tornar o texto claro para os receptores da cultura de chegada, e a lealdade, que leva em consideração as intenções e expectativas de todos os parceiros na interação comunicativa que é a tradução. Ressalta ainda, que levar em consideração não significa fazer o que os outros esperam que o tradutor faça, mas explicar seus objetivos e métodos tradutórios, caso eles sejam contraditórios em 
relação àquelas expectativas. Seu conceito de lealdade na tradução é definido da seguinte forma:

Lealdade não é a velha fidelidade em nova roupagem. Fidelidade refere-se à relação mantida entre o texto-fonte e o texto de chegada como entidades linguísticas [...] Lealdade, por outro lado, é uma categoria referente a um relacionamento entre pessoas. Ela pode ser definida como a responsabilidade que tradutores têm para com seus parceiros na interação translacional. $A$ lealdade compromete o tradutor de forma bilateral, tanto com a fonte quanto com a meta. ${ }^{28}$ (2001: 195)

Esse duplo comprometimento, ao mesmo tempo que incentiva o tradutor a assumir uma postura de resistência aos valores culturais do idioma de chegada, procurando conduzir o olhar do leitor para as diferenças linguísticas e culturais do texto estrangeiro (VENUTI 2004: 23, 41), não deve perder de vista que a tradução é uma ação comunicativa, e como tal, é necessário que o texto-alvo seja legível e inteligível. Esse acordo entre uma proposta estrageirizante, que promova a percepção das diferenças, com a clareza que aproxima o leitor do texto traduzido, define a busca do caminho do meio, que representa a atitude tradutória eleita para o presente trabalho.

Ainda quanto à tipologia funcional de Nord, destacamos a tradução exotizante (exotisierende Übersetzung), definida pela autora como

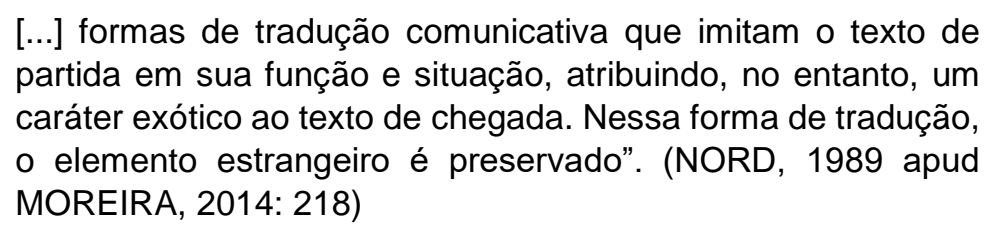

Consideramos essa última tipologia citada bastante apropriada para o escopo definido em nosso trabalho, pela preservação do elemento estrangeiro no texto de chegada, o que causa aquele efeito de estranhamento no leitor ao ser convidado a se confrontar com a alteridade, a lidar com um sistema diferente daquele com o qual está

\footnotetext{
${ }^{28}$ Loyalty is not the old faithfulness or fidelity in new clothes. Faithfulness and fidelity referred to a relationship holding between the source and the target texts as linguistic entities [...]. Loyalty,on the other hand, is a category referring to a social relationship between people. It can be defined as the responsibility translators have toward their partners in translational interaction. Loyalty commits the translator bilaterally to both the source and the target side.
} 
habituado a conviver, e identificamos traços semelhantes entre essa abordagem e a de Berman com relação a abrir espaço para o estrangeiro em nossa própria língua.

O teórico belga André Lefevere (1945 - 1996), em seu livro Translation, Rewriting and the Manipulation of Literary Fame (1992) desenvolveu a noção de reescrita. Segundo ele, a tradução é uma das principais formas de reescrita de um texto anterior, ao lado de resenhas, resumos, críticas, adaptações, antologias, etc. de acordo com Lefevere:

\begin{abstract}
(re)escrita é manipulação, realizada a serviço do poder, e em seu aspecto positivo pode ajudar no desenvolvimento de uma literatura e de uma sociedade. As reescritas podem introduzir novos conceitos, novos gêneros, novos recursos, e a história da tradução é também a história da inovação literária, do poder formador de uma cultura sobre outra. Mas a reescrita também pode reprimir a inovação, distorcer e controlar, e em uma época de crescente manipulação de todos os tipos, o estudo dos processos de manipulação da literatura, exemplificado pela tradução, pode nos ajudar a adquirir maior consciência a respeito do mundo em que vivemos. (LEFEVERE, 1992, apud MARTINS, 2010: 62)
\end{abstract}

Essa abordagem foi feita a partir da teoria dos polissistemas, de Itamar EvenZohar (Tel Aviv, 1939), que considera a literatura traduzida como um subsistema do sistema literário geral, em que a tradução é vista como uma reescrita produzida e lida segundo uma grande variedade de determinantes ideológicos e políticos, tanto de natureza objetiva como subjetiva.

Na noção de reescrita de Lefevere não existe um original no sentido clássico de uma criação individual, pois toda obra resulta de leituras e impressões anteriores. Para esse autor, a ideia de um gênio individual, ou da possibilidade de se conhecer a intenção do autor, deriva de visões do romantismo sobre a criação artística, em que o trabalho do tradutor é mais uma versão das ideias que perpassam o texto de partida.

Do mesmo modo que o autor do texto de partida, o tradutor está igualmente sujeito a uma série de fatores que determinam a sua escritura e que podem ser classificados em três níveis. Num primeiro nível, esses fatores são intrassistêmicos: a linguagem, o universo do discurso e a poética. Além deles, há a ação de forças regulatórias intrínsecas ao sistema literário, que se manifestam na ação dos profissionais diretamente sobre a criação da reescrita. Esses profissionais são os tradutores, resenhistas, escritores, etc. Num terceiro nível encontra-se a ação de 
elementos externos ao sistema literário, que constituem a patronagem, categoria que inclui editores, governos, agentes, etc.

Na categoria linguagem, vista como fator intrassistêmico, Lefevere destaca as diferenças entre texto de partida e de chegada e os variados tipos de movimentos linguísticos ditados por critérios estéticos e ideológicos dominantes em cada período. O universo do discurso refere-se ao conhecimento, educação e também aos objetos e costumes de uma dada época. A poética possui dois componentes: um inventário, que reúne o repertório de gêneros, dispositivos literários, motivos, determinados símbolos e personagens e situações prototípicos; outro, funcional, que caracteriza de que forma a literatura deve ou pode funcionar dentro da sociedade.

De acordo com Lefevere, os profissionais são os indivíduos que elaboram os critérios estéticos, controlam o sistema literário e filtram o que entra e o que sai do sistema. Esses indivíduos podem se organizar em entidades, como academias, em que estabelecem como objetivo normatizar e regular a atividade literária.

Partindo do conceito de reescrita, a patronagem constitui a categoria que reúne os elementos de poder externo. Estes interferem sobre os demais níveis. Podem ser indivíduos ou instituições, e estão mais preocupados com os aspectos ideológicos no sistema literário do que com a poética. A patronagem atua a partir de três bases, ideológica, econômica e o status, como define LEFEVERE (1985: 17-19)²9:

\begin{abstract}
A patronagem consiste basicamente de três elementos que podem ser vistos interagindo em várias combinações. Há um componente ideológico, que age como uma limitação na escolha e no desenvolvimento de formas e assuntos. Desnecessário dizer, "ideologia" aqui é entendida num sentido não limitado à esfera política; [...] Há também um componente econômico: o patrono providencia que os escritores e os reescritores sejam capazes de ganhar a vida, dando-lhes uma pensão ou indicando-os para algum cargo. [...] Finalmente, há também um elemento de status envolvido. A aceitação da patronagem implica integração em um grupo de apoio e em seu estilo de vida [...].
\end{abstract}

\footnotetext{
${ }^{29}$ Patronage basically consists of three elements that can be seen to Interact in various combinations. There is an ideological component, which acts as a constraint on the choice and development of both form and subject matter. Needless to say, "ideology" is taken here in a sense not limited to the political sphere; [...] There is also an economic component: the patron sees to it, that writers or rewriters are able to make a living, by giving them a pension ou appointing them to some office. [...] Finally, there is also an element of status involved. Acceptance of patronage implies integration into a support group and its life style [...].
} 
O sistema de patronagem nos fornece reflexões importantes, se levarmos em consideração a divulgação desta tradução comentada, elaborada para a presente dissertação. Considerando a estratégia estrangeirizante, não adaptada aos padrões editoriais, utilizada na tradução do trecho Bahia para este trabalho, é provável que apareçam alguns obstáculos para uma eventual publicação da tradução. Nesse caso, de nossa parte, teríamos que lidar com o fator ideológico, ou seja, não abrir mão da visibilidade do tradutor, todavia, do outro lado estaria a questão do status, de ser inserido em um sistema, ou seja, de conquistar um outro aspecto da visibilidade. Quanto a achar esse caminho do meio, discorreremos brevemente no capítulo das considerações finais.

Segundo MARTINS (2010: 65), o trabalho de Lefevere desde meados da década de 1980 até o início de 1996, quando faleceu, teve como preocupação descrever a articulação do sistema de reescritas com as estruturas de poder e os agentes de continuidade em uma cultura. Assim, introduziu mais um elemento de extrema importância, o político. Suas ideias quanto à interação da tradução com a cultura e suas estruturas de poder são fundamentais para se entender o papel das editoras e das instituições que, através de incentivo e patrocínio, interferem nas decisões editoriais e na implementação de políticas culturais.

A leitura das considerações teóricas acima provocou reflexões quanto à minha dificuldade inicial ao traduzir o texto de Fichte para esta dissertação. Como podemos verificar no anexo desse trabalho, muitos trechos das primeiras páginas do livro ganharam várias versões, até chegar a um ponto mais coerente com a proposta de uma tradução não facilitadora, que preserva o elemento estrangeiro e não apaga os traços do autor.

A experiência foi, no início, acompanhada de angústias, por eu não conseguir achar uma só direção. Lembrei-me, então, do texto de Schleiermacher, em que o teórico aponta a impossibilidade de seguir os dois caminhos tradutórios expostos por ele. Eu tinha conhecimento de que deveria optar por um deles, mas como? As outras teorias, sobre encontrar um tom exotizante ou privilegiar o elemento estrangeiro foram 
compreendidas somente mais tarde, mas a partir do momento em que incorporei essa atitude, elas muito contribuíram para orientar minha tomada de rumo. Então, apesar de exercer o ofício da tradução profissionalmente e há alguns anos, senti-me como diante de uma bifurcação, sem saber exatamente o que fazer. Por um lado, minha prática como tradutora pública me exige uma atitude de explicitação, tenho que garantir que a mensagem seja transmitida da forma mais clara possível e seja recebida e interpretada sem muito esforço e nenhuma dúvida. Por outro, o trabalho que requer mais liberdade criativa, da qual necessito para trazer o leitor até o autor escolhido e colocá-lo em contato com o elemento estrangeiro, sem criar camuflagens e disfarces ou cuidando para que ele não se assuste, sem oferecer elementos para que ele continue em sua zona de conforto. Após essas considerações e análises, o exercício de tradução começou a fluir e a proporcionar o "prazer seguro", do qual fala Schleiermacher. 


\section{CAPÍTULO III}

\section{A tradução: minha oferenda para Xangô}

Como vimos, os procedimentos metodológicos adotados para este trabalho foram a pesquisa bio-bibliográfica contemplando o texto-fonte, os paratextos - em especial as capas -, parte da fortuna crítica de Hubert Fichte, bem como obras do campo dos estudos da tradução.

O passo-a-passo da pesquisa desenvolveu-se em alternância entre a realização de várias versões da tradução, cada uma delas com notas e comentários a respeito do estilo, de formas de linguagem, dos marcadores culturais, das soluções encontradas e suas justificativas, e a reflexão a partir das matrizes mencionadas acima. Desse modo, construímos uma metodologia que se desenvolveu da prática da tradução em interação com a teoria e vice-versa.

A tradução a seguir vem apresentada em uma versão bilíngue (Alemão/Português), em texto no formato de tabela com duas colunas. $O$ passo seguinte foi reordenar as notas por afinidade, separar as que constam da tradução das utilizadas para dar sustentação à estratégia. Estas últimas fazem parte do capítulo IV, em que as notas foram sistematizadas e relacionadas com as considerações dos capítulos I e II. 
TRADUÇÃO ANOTADA E COMENTADA DE BAHIA (p. 7 - 116),

PRIMEIRA PARTE DO LIVRO

XANGO. DIE AFROAMERIKANISCHEN RELIGIONEN. BAHIA. HAITI. TRINIDAD

(XANGÔ. AS RELIGIÕES AFRO-AMERICANAS. BAHIA. HAITI. TRINIDAD), DE

HUBERT FICHTE

ORIGINAL

XANGO.

Die afroamerikanischen Religionen.

Bahia, Haiti, Trinidad

\section{Seite 7}

Eine abschüssige Strasse.

Altes Klopfsteinpflaster, das ehemals von Sklaven zusammengeklopft wurde.

Eine Strasse wie hundert andre in der Stadt, wie tausend andre in Brasilien.

Die Strasse ist sumpfig durch die Rinnsale von Exkementen, Waschwasser, Küchenwasser.

Die bissexuelle Absteige ist noch immer im demselben Haus.

Das Gebäude daneben trägt die Kreidenschrift «Familia»; die Bewohner wollen nicht mit den Nutten und Strichjungen verwechselt werden.

Aus dem Haus kommt ein etwa zehnjähriger Junge und legt eine Ratte auf das Pflaster.

Die Absteige hat kein elektrisches Licht.

Gibt es nicht bei Goethe eine Bemerkung über das Glänzen der Haut im Kerzenlicht?
TRADUÇÃO

XANGÔ.

As religiões afro-americanas.

Bahia, Haiti, Trinidad

Página 7

Uma rua íngreme.

Antiga calçada de paralelepípedos, que outrora foram juntados a marteladas por escravos.

Uma rua como centenas de outras na cidade, como milhares de outras no Brasil.

A rua é pantanosa pelos regatos de excrementos, água de lavagem, água da cozinha.

O hotelzinho bissexual barato ainda está na mesma casa.

O prédio ao lado traz a inscrição em giz: "Familia"; os moradores não querem ser confundidos com as putas e os garotos de programa.

Da casa sai um menino de uns dez anos e coloca uma ratazana na calçada.

O hotelzinho barato não tem luz elétrica.

Não há em Goethe uma observação sobre o brilho da pele à luz da vela? 
Hier war Goethe nicht. Doch wo Goethe nicht hinkam, war Italiaander.

Es gibt in der Absteige kein fliessendes Wasser - die beste Syphilisprophylaxe ist klares Wasser -, die Möglichkeit sich gründlich zu waschen. Das Wasser in diesem Viertel wird auf den Köpfen der Frauen und Kinder herantransportiert.

Die Häufigkeit von Geschlechtskrankheiten in der Stadt ist also weder auf Laszivität, noch auf Unsauberkeit oder Faulheit zurückzuführen, sondern auf Mangel an Klempnern.

Auch soll nicht Bahia an der Spitze der Statistik über Geschlechtskrankheiten stehen - dort steht die Freie und Hansestadt Hamburg.

Die Kojen in den ehemaligen Kaufmannspalästen sind durch Wolldecken oder durch Pappstücke mit Gucklöchern abgetrennt.

Ein Schüsselchen mit Wasser steht neben einer Rolle Klosettpapier und zwei Heiligfiguren und Plastikblumen und Parfümfläschen.

Die Stundenmiete beträgt zwei Cruzeiros zwei Mark. Die Mädchen oder Jungen bekommen das Doppelte.

\section{Seite 8}

Der Liftboy im Hotel ist 16 Jahre alt.

Er arbeitet sechs Stunden täglich und verdient 60 Cruzeiros, 40 Mark im Monat. Er bekommt kein Essen im Hotel.

Er hat Hunger.
Aqui Goethe não esteve. Mas aonde Goethe não foi, lá esteve Italiaander.

Não há no hotelzinho água corrente - a melhor profilaxia da sífilis é água clara -, a possibilidade de se lavar completamente $A$ água nesse bairro é transportada para cá sobre as cabeças das mulheres e das crianças.

A frequência das doenças sexuais na cidade não se deve, portanto, à lascívia, nem à não limpeza ou a preguiça, mas à falta de encanadores.

Também não deve estar a Bahia no topo da estatística sobre doenças sexuais - lá está Hamburgo, Livre e Hanseática cidade de Hamburgo.

Os leitos nos antigos palácios dos comerciantes são separados por cobertores de lã ou papelões com furos para espiar.

Uma baciazinha com água está ao lado de um rolo de papel higiênico e duas imagens de santos e flores de plástico e vidrinhos de perfume.

O aluguel por hora é de dois cruzeiros - dois marcos. As garotas ou garotos recebem o dobro.

\section{Página 8}

O Liftboy no hotel tem 16 anos.

Ele trabalha seis horas diariamente e ganha 60 cruzeiros, 40 marcos por mês. Ele não recebe nenhuma comida no hotel.

Ele tem fome. 
In den besseren Vierteln der Stadt wird gebaut. Viel. Hochhäuser à la Mies van der Rohe.

Touristen wohnen in den besseren Vierteln der Stadt, Geschäftsleute, Politiker, Diplomaten, international Delegationen; Dichter, Maler, die sich arrangiert haben.

Die Wohnungen kosten bis zu 4500 Cruzeiros. Zwei Badezimmer.

Drei Klosetts.

Die Kammer für die Hausangestellte: 4 Quadratmeter. Kein Fenster.

\section{Redakteur S.:}

-Die Militärs haben die Presse vollkommen in der Hand.

Der Correo da Manha, eines der wenigen unabhängigen Blätter in Rio, wurde über die Anzeigenkunden ruiniert.

Vor Angst ist die Selbstzensur oft stärker als die Staatliche Zensur.

Was noch an harten Artikeln erscheint, geschieht auf eigenes Risiko der Journalisten.

Die Telefone werden überwacht. Theater auch und Chansonsänger.

Pop Art darf nicht ausgestellt werden.

Die brasilianische Malerei ist tot.

Die Justiz ist teilweise noch intakt. Einige Richter weigern sich, unter Folter gemachte Aussagen anzuerkennen.

Zum »Tourismus «, um die Adresse von P. zu erfahren, dem weissen Papst des schwarzen Candomblé.

Nos melhores bairros da cidade se contrói. Muito. Prédios altos à la Mies van der Rohe.

Turistas alojam-se nos melhores bairros da cidade, homens de negócio, políticos, diplomatas, delegações internacionais; poetas, pintores que se deram bem.

Os apartamentos custam até 4.500 cruzeiros. Dois banheiros.

Três privadas.

A alcova dos empregados domésticos: 4 metros quadrados. Nenhuma janela.

***

Redator S.:

- Os militares têm a imprensa inteiramente na mão.

O Correo da Manha, uma das poucas folhas de notícias independentes no Rio, foi arruinado pelos anunciantes.

Por medo, a autocensura é muitas vezes mais forte que a censura estatal.

O que ainda aparece de artigos duros, ocorre por conta e risco dos próprios jornalistas.

Os telefones são monitorados. Teatros também e cantores de canção popular brasileira.

A Pop Art não pode ser exibida.

A pintura brasileira está morta.

A justiça está, em parte, ainda intacta. Alguns juízes se recusam a reconhecer declarações feitas sob tortura.

Ao "Turismo", saber o endereço de P., o papa branco do candomblé negro. 
Ein zitternder Angestellter mag mir die Adresse nicht nennen und er mag sie mir nicht nicht nennen.

Er gibt mir zu verstehen, wo P. wohnt.

Ohne zu kompromittieren.

\section{Seite 9}

Er zittert wieder.

Was hat er nur?

In welcher Maschienerie hängt der Mann und zappelt -

erbarmungswürdig und erbärmlich?

P. wohnt in Vila America, einer Siedlung aus Lehmhäusern mit kleinbürgerlichen Zementfassaden gelegentlich.

Nicht alle haben fliessend Wasser und Abflussrohre.

Man muss durch einen verwilderten Garten rufen.

P. kommt.

Ein Mann um die sechzig. Bis zu den Hüften buddhaartig nackt, um den Unterleib ein afrikanisches Batiktuch.

Er empfängt mit ironischem Misstrauen.

Vielleicht gefällt ihm mein Akzent. Er führt mich in sein Arbeitszimmer, wo Lehmstaub die wenigen Reisekisten und die Regale bedeckt. Ein paar afrikanische Kultplastiken, zwei primitive Bilder.

Der ehemalige Fotograf $P$. lebt fast unter den gleichen Bedingungen wie seine proletarischen Nachbarn.

Er bietet mir Zuckerrohrschnaps an, mit Zitrone, «Batida», er redet von seiner Arbeit.

Er fotografiert gar nicht mehr. Er lebt nur noch als Religionswissenschaftler und Ethnopharmakologe.
Um trêmulo empregado não quer me dar o endereço e ele não quer não me dar o endereço.

Ele me dá a ententer onde P. mora.

Sem se comprometer.

\section{Página 9}

Ele treme novamente.

O que ele tem, afinal?

Em que maquinaria o sujeito se dependura e se debate -

digno e passível de pena?

P. mora na Vila America, um assentamento de casas de barro com fachadas de cimento pequeno-burguesas ocasionalmente.

Nem todas têm água corrente e canos de esgoto.

Tem-se que chamar através de um jardim asselvajado.

P. vem.

Um homem em torno dos sessenta. Até os quadris, nu à maneira de um Buda, ao redor do baixo-ventre um lenço de batik africano.

Ele me recebe com irônica desconfiança.

Talvez Ihe agrade meu sotaque. Ele me conduz a sua sala de trabalho, onde o pó do barro cobre os poucos baús de viagem e as prateleiras. Algumas estátuas africanas de culto, duas imagens primitivas.

O ex-fotógrafo $P$. vive quase sob as mesmas condições que seus proletários vizinhos.

Ele me oferece aguardente de cana de açúcar com limão, "Batida", ele fala sobre seu trabalho.

Ele parou de vez de fotografar. Ele vive apenas como cientista da religião e etnofarmacólogo. 
Er schreibt an einer umfangreichen Kartei und registriert die Anwendug afrikanischer Pflanzen in den Candomblés von Bahia.

Ein junger Afrikaner sitzt stumm bei unserem Gespräch.

- Er hilft mir im Haushalt.

Der »Candomblé von Oxumaré « in der Vila Americana zwischen Favelahütten.

Unordnung.

Die Mãe de Santo, die Priesterin, ist vor zwei Jahren gestorben und jetzt funtioniert nichts mehr. Der Mann der Verstorbenen, der in der religiösen Hierarchie keinerlei Bedeutung hat, der sich aber nicht aus dem Kulthaus, wo er wohnt, weisen lassen will, schimpft auf die «Nutten», die nicht rechtzeitig zum Gottesdienst erscheinen.

Schliesslich sind etwa 100, über den Niedergang ihres Candomblés beschämte Gläubige zusammen - mehr Frauen als Männer.

Die Töchter der Götter erscheinen in dem vorwurfsvollen Weiss der Armen.

\section{Seite 10}

Trommeln. Tanzen im Kreis. Ein bisschen lanweilig für den Neuankömmling - für den Kenner vom Understatement des Orthodoxen.

Die Götter zögern herabzusteigen. Dann wenig spektakuläre Ekstasen.

Antonio, der schweigsame Gehilfe von P., führt uns in den Candomblé von Camilo auf dem gegenüberliegenden Hügel.

Hier ist es bunt und theatervoll. Karnavaleske Götterkostüme. Leonore darf fotografieren.

Ele está escrevendo um extenso catálogo e registra 0 uso de plantas africanas nos candomblés da Bahia.

Um jovem africano está sentado mudo durante nossa conversa.

- Ele me ajuda nos afazeres domésticos.

***

O "Candomblé de Oxumaré" na Vila Americana entre barracos de favela.

Desordem.

A mãe de santo, a sacerdotisa, morreu há dois anos e agora nada mais funciona. O marido da falecida, que na hierarquia religiosa não tem nenhuma importância, mas que não aceita ser colocado para fora da casa de culto onde mora, xinga as "putas", que não aparecem na hora certa para o serviço religioso.

Por fim, são cerca de 100, fiéis envergonhados do declínio de seu candomblé - mais mulheres que homens.

As filhas de santo aparecem no branco repreensível dos pobres.

\section{Página 10}

Tambores. Dança em círculos. Um pouco chato para o recém-chegado - para o conhecedor do understatement do ortodoxo.

Os deuses hesitam em baixar. Depois, êxtases menos espetaculares.

Antonio, o silencioso ajudante de P., nos conduz ao candomblé de Camilo no morro do que fica do lado oposto.

Aqui é colorido e teatral. Fantasias carnavalescas dos deuses. Leonore pode fotografar. 
Wir werden zur gemeinsamen, kultischen Mahlzeit der Gläubigen und der Priester gebeten.

Die afrikanischen Gerichte Vatapa, Kalulu, Efo schmecken gut.

Die Gläubigen ziehen nächtelang von einem Candombléfest zum anderen.

Manche schlafen trotz des Lärms der drei Trommeln vor Erschöpfung ein.

Ein Cowboy legt auf einen Essenden an und gibt dem zu verstehen, dass er mehr essen soll. Schneller.

Der beginnt zu fressen, in sich hineinzustopfen, erbricht vor der Pistole seinen Frass.

Er wird abgeknallt.

Die Leute im Cine Pax wollen sich totlachen.

Aussprüche meiner Landsleute:

- Dass mir der Junge hier nicht verwildert!

- Die Neger sind eben doch noch nicht so weit.

- Wir können den Jungen doch morgens nicht im Bus mit den Arbeitern fahren lassen.

- Es muss positiv berichtet werden.

- Unser Club.

- Konstruktive Kritik.

- Der Junge spielt Tennis.

- Wie mir die israelische Botschaft vertraulich mitteilte.

- Ich habe das E.K. 1.

- Ich bin rosa.

\section{Seite 11}

Somos chamados para a refeição ritual conjunta dos fiéis e dos sacerdotes.

Os pratos africanos vatapá, caruru, efó são saborosos.

Os fiéis vão por noites inteiras de uma festa de cadomblé a outra.

Alguns adormecem, apesar do barulho dos três tambores, de exaustão.

***

Um cowboy aponta a arma para um comedor e dá a entender que ele deve comer mais. Mais rápido.

Ele começa a devorar, a enfiar-se a comida para dentro, vomita diante da pistola sua forragem.

Ele é abatido a tiros.

As pessoas no Cine Pax querem morrer de rir. ***

Palavras ditas pelos meus conterrâneos:

- Que o menino aqui não se asselvage!

- Mas os negros ainda não estão tão adiantados.

- Nós não podemos deixar o menino andar de ônibus de manhã com os trabalhadores.

- Tem-se que relatar positivamente.

- Nosso clube.

- Crítica construtiva

- O menino joga tênis.

- Como a Embaixada israelense me informou confidencialmente.

- Eu tenho a Cruz de Ferro de $1^{\mathrm{a}}$ classe.

- Eu sou rosa.

\section{Página 11}


- Langsam, langsam. Die Revolution hat hier keinen Zweck.

- Das muss hier alles bahianisch gehen - mit Samba.

- Ich lese regelmässig die Luftpostausgabe der »Welt«

- Meine Frau bekommt hier sogar Maggi Streuwürze.

- Ich arbeite am liebsten mit reinen Negern. Die Mischlinge sind völlig unbrauchbar. Die meisten sind durch Gelegenheitsarbeit vollständig versaut.

- Die Japaner sagen in São Paulo zu den Deutschen: Wir Europäer!

- Es gibt Folter und Folter. Es kommt darauf an, ob sie dienlich ist oder nicht.

Ich begegne im Bus einem etwa siebzigjährigen Maurer.

Er arbeitet am Bau einer Luxusvilla dem Meer gegenüber.

Er kommt vom Markt und hält ein Stück Fleisch auf dem Schoss, das riecht etwas.

Wie kann der abgezehrte Mann die Arbeit auf dem Bau noch bewältigen?

- Ich bin sechsundfünfzig.

- Ich bin verheiratet.

- Ich habe elf Kinder.

- Eine meiner Töchter ist verheiratet.

- Ein Junge lebt im Landesinneren.

- Ich arbeite acht Stunden am Tag.

- Sechs Tage in der Woche.

- Ich verdiene 42 Cruzeiros in der Woche.

Das ist weniger als ein Cruzeiro in der Stunde -66 Pfennig.

- Devagar, devagar. A revolução não tem sentido aqui.

-Tudo aqui tem andar bahianamente - com samba.

- Eu leio regularmente a edição pelo correio aéreo do »Welt«.

- Minha mulher recebe aqui até o tempero granulado da Maggi.

- Eu prefiro trabalhar com negros puros. Os mestiços são totalmente inutilizáveis. A maioria está completamente emporcalhada por trabalhos temporários.

- Os japoneses dizem em São Paulo para os alemães: Nós europeus!

- Há torturas e torturas. Depende, se elas servem ou não.

$\star \star \star *$

Eu encontro no ônibus um pedreiro de uns setenta anos.

Ele trabalha na construção de uma mansão de luxo em frente ao mar.

Ele vem do Mercado e segura um pedaço de carne no colo, ela cheira um pouco.

Como pode o homem carcomido ainda levar a cabo o trabalho na construção?

- Eu tenho cinquenta e seis.

- Eu sou casado.

- Eu tenho onze filhos.

- Uma das minhas filhas é casada.

- Um menino vive no interior.

- Eu trabalho oito horas por dia.

- Seis dias na semana.

- Eu ganho 42 cruzeiros por semana.

Isso é menos que um cruzeiro por hora - 66 Pfennig. 
- Ich habe in der Nähe des Flughafens ein Haus für 80 Cruzeiros im Monat gemietet. In Landesinnerern besitze ich selbst ein Haus, das vermiete ich für das gleiche Geld. Ich wohne also praktisch umsonst.

- Die Jungen arbeiten gelegentlich etwas mit.

- In der Woche verbrauchen wir 15 Kilo Maniokmehl, 3 bis 4 Kilo Bohnen, 3 bis 4 Kilo Reis.

- Für Gemüse haben wir kein Geld.

- Früchte müssen die Kinder von den Bäumen holen.

- Wenn ich Zeit habe, angeln zu gehen, gibt es Fisch.

- Sonnabends hole ich manchmal ein Stück Fleisch.

\section{Seite 12}

Die Familie lebt also von zwei Kilo Reis am Tag - 11 Personen: Das sind 180 Gramm Maniokmehl, 45 Gramm Bohnen, 45 Gramm Reis für jeden.

- Ich lese keine Zeitung.

- Ich lese nicht die Bibel. Ich kann gar nicht lesen. Aber an Gott glaube ich nicht. Ich gehe nicht in den Candomblé.

- Ich stelle sehr unagenehme Fragen: Warum haben die Apostel keine Nachnamen?!

Donnerstag, den 7. Januar 1971: A Tarde:

Der 12jährige Marcos Corréa Paz wird von der Polizei während der Verfolgung von Rauschgifthändlern erschossen.

Drei Tage vorher war in Rio de Janeiro der Junge Evanir unter ähnlichen Umständen von der Polizei erschossen worden.
-Eu aluguei perto do aeroporto uma casa por 80 cruzeiros por mês. No interior eu mesmo possuo uma casa, eu alugo ela pelo mesmo dinheiro. Assim, eu moro praticamente de graça.

- Os meninos trabalham de vez em quando comigo.

- Na semana nós gastamos 15 quilos de farinha de mandioca, 3 a 4 quilos de feijão, 3 a 4 quilos de arroz.

- Para legumes e verduras nós não temos dinheiro.

- Frutas as crianças têm que apanhar das árvores.

- Quando eu tenho tempo para ir pescar, tem peixe.

- Sábado eu busco às vezes um pedaço de carne.

\section{Página 12}

A família vive então com dois quilos de arroz por dia -11 pessoas: são 180 gramas de farinha de mandioca, 45 gramas de feijão, 45 gramas de arroz para cada um.

- Eu não leio nenhum jornal.

- Eu não leio a Bíblia. Eu nem sei ler. Mas em Deus eu não acredito. Eu não vou ao candomblé.

- Eu faço perguntas muito desagradáveis: por que os apóstolos não têm nenhum sobrenome?! ***

Quinta-feira, 7 de janeiro de 1971: A Tarde:

O Marcos Correa Paz, de 12 anos, é morto a tiros pela polícia durante uma perseguição a comerciantes de drogas.

Três dias antes, no Rio de Janeiro, o jovem Evanir foi morto pela polícia a tiros em circunstâncias semelhantes. 
Bei dem Versuch, einen Streit zu schlichten, erschiessen drei Nachtwächter in São Paulo den 12jährigen Fernando Antonio Pereira Sapucaia.

P. meint, es gebe in der Stadt Bahia etwa 900 000 Afrikaner und Mulatten, nur ein Zehntel der Bevölkerung sei weiss.

Er schätzt die Zahl der Candomblés in der Stadt auf etwa 600 .

Der älteste, Engenho Velho oder Casa Branca, sei nicht 300 Jahre alt, wie Jorge Amado behauptet, sondern nur etwa 130 .

Vor 300 Jahren habe es noch gar keine Nago in Bahia gegeben.

Die Nago seien erst nach dem offiziellen Verbot der Sklaverei nach Bahia verschleppt worden.

Drei Viertel der Bevölkerung besuchen die Feste der Candomblés.

Auch diejenigen, die auf Grund ihrer Position so tun müssen, als glaubten sie nicht an den afrobrasilianischen Synkretistimus, lassen im Geheimen oder über ihre Dienstboten die afrikanischen Priester für sich arbeiten.

Alle Anhänger des Candomblé sind gläubige Katholiken.

\section{Seite 13}

Mit Antonio durch die Candomblés der Vila America.

Vor dem Engenho Velho steht ein zehn Meter langes, heiliges Betonschiff mit vergoldeten Zementvasen; nich weit davon ein brunnenförmiges Wasserbasin voller üppigem Froschkraut - auf dem Verputzt des Bassins eine gemalte Schlange: Oxumare, der Regenbogen.
$\mathrm{Na}$ tentativa de aplacar uma briga, três vigias noturnos em São Paulo matam a tiros Fernando Antonio Pereira Sapucaia, de 12 anos.

$* * *$

P. acha que há na cidade da Bahia cerca de 900.000 africanos e mulatos, só um décimo da população seria branca.

Ele calcula o número de candomblés na cidade em cerca de 600.

O mais antigo, Engenho Velho ou Casa Branca, não teria 300 anos, como Jorge Amado afirma, mas somente cerca de 130.

Há 300 anos não teria havido ainda nagôs na Bahia.

Os nagôs teriam sido arrastados para a Bahia só depois da proibição oficial da escravidão

Três quartos da população frequentam as festas dos candomblés.

Até aqueles que por causa da sua posição tem que agir como se não acreditassem no sincretismo afro-brasileiro, mandam em segredo, ou pelos seus mensageiros, os sacerdotes africanos trabalharem para eles.

Todos os adeptos do candomblé são fiéis católicos.

\section{Página 13}

Com Antonio pelos candomblés da Vila America.

$\mathrm{Na}$ frente do Engenho Velho ergue-se um barco sagrado de concreto, de dez metros de comprimento, com vasos de cimento dourados; não longe dali, uma bacia de água em forma de fonte cheia de exuberantes ervas-de-sapo sobre o reboco da bacia, a pintura de uma cobra: Oxumaré, o arco-íris. 
Der Priester Siriaco ist gestorben und sein Tempel verfällt.

Eine ältere Afrikanerin mit komplizierter Frisur kann uns nicht sagen, wann es wieder ein Götterfest geben wird.

An einem Baum Opfergaben, Puppen, Topfpflanzen, Schlingpflanzen, geistliche Fahnen.

Im Novo Engenho Velho flieht ein Mädchen vor uns. Eine Alte sagt uns, im Februar wird es ein Fest geben.

Beim Priester Domingo ist eine Priesterin gestorben und ein Jahr lang dürfe kein Fest gefeiert werden.

Nackte Kinder in dem grossen religiösen Versammlungsraum, Ziegen und fickende Hunde.

Antonio fängt an zu reden:

- Mein Vater arbeitet als Anstreicher. Aber er hat keine feste Anstellung.

- Ich habe zwei Schwestern. Eine lernt Stenotypistin.

- Ich habe einen Bruder.

- Wir leben mit sechs Personen in einem kleinen Lehmhaus.

- Ich möchte Lastwagenfahrer werden. Dann verdiene ich 300 Cruzeiros - 200 Mark - im Monat.

- Ich arbeite mal hier, mal da.

- Meine Freundin ist nach Rio gezogen. Jetzt brauche ich eine neue.

- Männer oder Frauen, das ist mir egal. Vielen hier.
O sacerdote Siriaco morreu e seu templo está em decadência.

Uma velha africana com penteado complicado não sabe nos dizer quando haverá novamente uma festa dos deuses.

Em uma árvore, oferendas de sacrifícios, bonecas, plantas em vaso, plantas trepadeiras, bandeiras do culto religioso.

Em Novo Engenho Velho foge uma menina de nós. Uma velha nos diz, em fevereiro haverá uma festa.

No sacerdote Domingo morreu uma sacerdotisa e por um ano não se poderia celebrar nenhuma festa.

Crianças peladas na grande sala de reunião religiosa, cabras e cachorros fodendo.

$* * *$

Antonio começa a falar:

- Meu pai trabalha como pintor de paredes. Mas ele não tem um emprego fixo.

- Eu tenho duas irmãs. Uma aprende estenotipista.

- Eu tenho um irmão.

- Nós vivemos com seis pessoas numa pequena casa de barro.

- Eu quero ser motorista de caminhão. Então eu ganho 300 cruzeiros - 200 marcos - por mês.

- Eu trabalho vez aqui, vez acolá.

- Minha namorada se mudou para o Rio. Agora eu preciso de uma nova.

- Homens ou mulheres, isso para mim é igual. Para muitos aqui. 
- In der Stadt gibt es Schwule, die bezahlen dafür.

- Ich habe lange Zeit mit einem Franzosen zusammengelebt. Aber der ist jetzt weg.

\section{Seite 14}

Im Cine Arte, einem nicht ganz unambivalenten Kino, läuft regelmässig «O mundo das noticias" - "Die Welt der Nachrichten« -, eine Wochenschau der Deutschen Reportagefilm.

Die brasilianischen Arbeiter, die Liebespaare, das Subproletariat von Bahia de Todos os Santos sehen also die Herrenmode aus Berlin, Hamburger Hafenansichten, Geigen aus dem Schwarzwald und eine Pudelausstellung in Düsseldorf; dazu Fussball und Rugby aus London.

***

Der bundesdeutsche Reisende kann im Ausland auf das Wohlwollen der Bevölkerung rechnen:

-Hitler, so!

Wir gelten als männlich, seriös, mutig, arbeitsam, reich. Dies Image hilft uns auch über gebrülte «Hugos», »Ernsts«, über Bräuche, Taktlosigkeiten - «lhr Neger seid ja auch Menschen» -, Fettnakken hinweg.

Wie erstaunt sind wir also, wenn einer unserer Botschafter entführt wird.

Uns greift man an, die wir Lehrlingsstipendien geben, Bildungsfernsehen finanzieren, Erdbebenopfern helfen. Fabriken bauen und Staudämme?!

Ich bemerke in Bahia, dass sich die Türen der Intellektuellen schliessen, wenn ich meine Nationalität angebe.

Ich bemerke zum ersten Mal, dass wir Bundesdeutschen in einem Entwicklungsland unter einer Militärdiktatur für mitschuldig
Na cidade tem viados, eles pagam por isso.

- Eu vivi muito tempo com um francês. Mas ele agora foi embora.

\section{Página 14}

No Cine Arte, um cinema não muito não ambivalente, passa regularmente "O mundo das notícias" - em alemão: "Die Welt der Nachrichten" - um jornal semanal da Deutsche Reportagefilm.

Os trabalhadores brasileiros, os pares românticos, o subproletariado da Bahia de Todos os Santos veem a moda masculina de Berlim, vistas do porto de Hamburgo, violinos da Floresta Negra e uma exposição de poodles em Düsseldorf; além disso, futebol e rugby de Londres.

***

O viajante da República Federal da Alemanha pode, no estrangeiro, contar com a benevolência da população:

- Ah, Hitler!

Nós somos considerados viris, sérios, corajosos, trabalhadores, ricos. Essa imagem nos ajuda a sobrepujar até mesmo trovejantes «Hugos», Ernsts «, costumes, falta de tato - «Vocês pretos também são seres humanos» -, gafes.

Quão surpresos ficamos, pois, quando um dos nossos embaixadores é sequestrado.

Nos atacam por darmos bolsa de estudos para aprendizes, financiarmos canais de televisão educativa, ajudarmos vítimas de terremotos. Construir fábricas e barragens?!

Eu percebo na Bahia que as portas dos intelectuais se fecham quando eu informo minha nacionalidade.

Eu percebo pela primeira vez que nós, cidadãos da República Federal da Alemanha em um país em desenvolvimento sob uma ditadura militar, somos declarados coculpados, que nos 
erklärt werden, dass man uns wegen unserer Entwicklungspolitik verachtet.

Es sind Intellektuelle, die sehr genau beobachten, mit welchen Politikern wir uns an einen Tisch setzen, Intellektuelle, die nicht vergessen, dass kein bundesdeutscher Nobelpreisträger die Zeit fand, Chile unter der Regierung Allende zu besuchen.

Vor dem Gerichtsmedizin Institut "Nina Rodriguez « im Prostituiertenviertel warten etwa hundert Menschen.

Auf zwei Betonbetten stehen zwei mit Silberpappe verzierte Särge. Ein mit weissen Blüten bedeckter Mann liegt in dem ersten.

\section{Seite 15}

Nur seine Nase, die Hände und die gelben Gummisohlen stechen aus den Blüten hervor; in dem zweiten Sarg daneben ein Junge.

Ich frage was dem Mann zugestossen sei.

- Ein Arbeitsunfall. Er kam ins Krankenhaus und dann hat man die Familie benachrichtigt, dass man inn hier zur Beerdigung abholen soll. Sie haben inn seziert.

- Ist die Familie gefragt worden?

- Nein. Jeder Tote wird seziert.

Der Beerdigungsunternehmer kommt und schliesst den Sarg über dem Arbeiter.

Eine Frau ruft:

- O, mein Sohn, jetzt kommst du nie mehr zurück.

Freunde und Verwandte tragen den Sarg hinaus, drei Kilometer weit, zu dem Friedhof der Armen, wo einige üppige Grabkonstruktionen am Eingang kulissenartig die elenden Holzkreuze und den fürchterlichen Ofen verbergen. desprezam pela nossa política desenvolvimentista.

São intelectuais que observam muito bem com quais políticos nós nos sentamos a uma mesa, intelectuais que não esquecem que nenhum alemão portador do Prêmio Nobel achou tempo para visitar o Chile sob o governo de Allende.

***

$\mathrm{Na}$ frente do Instituto Médico Legal "Nina Rodriguez" no bairro de prostituição esperam cerca de cem pessoas.

Sobre duas camas de concreto estão dois caixões decorados com papelão prateado. Um homem coberto com flores brancas está deitado no primeiro.

\section{Página 15}

Somente seu nariz, as mãos e as solas de borracha amarelas se sobressaem das flores; no segundo caixão ao lado, um menino.

Eu pergunto o que sucedeu ao homem.

- Um acidente de trabalho. Ele veio para o hospital e então avisaram a família, que deveriam buscá-lo aqui para o enterro. Eles o dissecaram.

- A família foi consultada?

- Não. Todo morto é dissecado.

O agente funerário chega e fecha o caixão sobre o trabalhador.

Uma mulher grita:

- Ah, meu filho, agora você não volta mais.

Amigos e parentes carregam o caixão para fora, numa distância de três quilômetros, para o cemitério dos pobres, onde alguns túmulos luxuosos na entrada escondem como um pano de fundo miseráveis cruzes de madeira e o horrível forno. 
Orlando sagt:

- Für die Beerdigung müssen die Leute monatelang arbeiten.

Der Sarg allein kostet 200 bis 400 Cruzeiros.

Leonore beobachtet auf dem Markt die Militärpolizisten.

Sie gehen von einem Stand zum anderen und wählen makellose Früchte aus und sacken sie ein.

Sie bezahlen nicht.

Die Regierungspropaganda stellt den Autofahrern kleine Aufkleber zur Verfügung:

- Brasilien - lieb oder lass es.

- Ich liebe dich, mein Brasilien.

- Niemand kann dieses Land mehr bremsen.

- Brasilien, du kannst auf mich zählen.

John, der amerikanische Anthropologe, erzählt, dass es in den Südstaaten der USA eine wörtlich fast gleiche Kampagne für die USA gegeben habe.

\section{Seite 16}

Der Karnaval hat sich von einem afrobrasilianischen Volksfest mit sozialkritischer Tendenz zu einem genau kontrollierten Ventil für das Bedürfnis der Massen nach Bewegungsfreiheit entwickelt.

In Rio de Janeiro fängt die berühmte Sambaschule Mangueira schon im September an, übungsweise für den Karnaval zu rasseln und zu klappern.

Fast ein halbes Jahr lang werden die mühsam ersparten Pailletten an Prachsatins und
Orlando diz:

- Para o enterro, as pessoas têm que trabalhar durante meses.

Só o caixão custa de 200 a 400 cruzeiros.

***

Leonore observa no mercado os policiais militares.

Eles vão de uma barraca a outra e escolhem frutas sem defeito e as colocam no saco.

Eles não pagam.

***

A propaganda do governo coloca à disposição dos motoristas pequenos adesivos:

- Brasil - ame-o ou deixe-o

- Eu te amo, meu Brasil.

- Ninguém segura este país.

- Brasil, você pode contar comigo.

John, o antropólogo americano, conta que nos estados sulinos dos EUA houve uma campanha literalmente quase igual para os EUA.

\section{Página 16}

O carnaval, de uma festa popular afro-brasileira com tendência sócio-crítica, se transformou em uma válvula precisamente controlada para as necessidades de liberdade de movimento das massas.

No Rio de Janeiro começa a famosa escola de samba Mangueira já em setembro a chocalhar e bater como treino para o carnaval.

Por quase um meio ano, os paetês economizados com esforço são costurados nos 
Festschleier genäht, bis endlich die Millionen von Rio, Bahia, Recife in ein krampfartiges Sambageschüttle geraten und ein paar Stunden glauben dürfen, die Strassen und die Medien gehörten ihnen.

- Dies Jahr haben sich 800 Militärpolizisten verkleidert, sagt João, der uns ein halb fertiggestelltes Häuschen vermietet hat.

Im Gerichtsmedizinischen Institut wird ein Mann seziert, der in der Menge einem Herzschlag erlegen ist.

Pelé, der schwarze Diener des Baumaterialienhändlers, verdient 120 Cruzeiros im Monat, 80 Mark.

Er steht morgens um fünf auf.

Mittags isst er im Stehen das, was übriggeblieben ist.

Früchte nicht. Früchte sind nur für die Kinder des Herrn.

Wenn die Angestellten sich Früchte aus dem Eisschrank nehmen, gibt es Krach.

Abends isst Pelé eine Suppe aus Brot, Wasser und Salz.

Ihm ist ganz schlecht davon.

Er bettelt bei uns um einen Schnaps.

Pelé fegt, schrubbt, bürstet, harkt, gräbt, manchmal wäscht er noch um Mitternacht den Wagen des Herrn.

Pelé ist das schwarze Nationalalibi der brasilianischen Republik.

Eine Peléstatue in jeder grösseren Stadt.

Die Illustrierten bringen Sondernummern: cetins esplendorosos e véus festivos, até que finalmente os milhões do Rio, Bahia, Recife entram num agito convulsivo do samba $e$ durante algumas horas podem acreditar que as ruas e os meios de comunicação lhes pertencem.

- Esse ano 800 policiais militares se fantasiaram, diz João, que nos alugou uma casinha semiacabada.

No Instituto Médico Legal um homem é dissecado, que na multidão foi acometido por um infarto.

***

Pelé, o empregado preto do comerciante de material de construção, ganha 120 cruzeiros por mês, 80 marcos.

Ele se levanta de manhã às cinco.

Ao meio-dia ele come em pé o que sobrou.

Frutas não. Frutas são somente para os filhos do Senhor.

Quando os empregados pegam frutas da geladeira, tem briga.

À noite Pelé come uma sopa de pão, água e sal.

Ele passa mal com isso.

Ele implora a nós por uma cachaça.

Pelé varre, esfrega, escova, passa o ancinho, cava, às vezes ele lava ainda à meia-noite o carro do Senhor.

***

Pelé é o álibi nacional preto da república brasileira.

Uma estátua do Pelé em cada grande cidade.

As revistas trazem números especiais: 
Historisches Dokument: Leben und Ruhm Pelés.

Pelé wirbt für Batterien.

\section{Seite 17}

Pelé wirbt für die Steuererklärung und für die Anzugproduktion seines Wirtschaftsimperiums.

Pelé wird vom Staatspräsidenten umarmt.

Pelé fährt Mercedes.

Pelé soll in Genf bei der Internationalen Arbeiterorganisation auftreten.

Pelé fährt als Botschafter des Herzens nach Paris und wird in Orly mit den Ehren eines Staatschefs empfangen.

Pelé mit B.B.

Pelé mit der Königin Elisabeth.

Am 17. Februar überreicht Pelé dem kranken François Duvalier auf Haiti einen brasilianischen Orden.

Das Ministerium für Erziehung und Kultur gibt drei Broschüren zur Bekämpfung des Analphabetismus heraus.

66 Seiten stark heisst eine davon «Mathematikbuch» und führt die Schüler bis zur Division 15 durch 4.

Das 66 Seiten starke Lesebuch wird durch 34 Seiten Übungen ergänzt.

Die Lektüre endet:

- Jetzt erhalten Sie Ihre Berufskarte, denn Sie können lesen und schreiben. Sie können auch die Wahlberechtigung erhalten und Ihre Militärdienstsbescheinigung gegen eine neue eintauschen, auf der vermerkt steht: Alphabetisiert.

In der neunten Lektion finden sich die Übungssätze:
Documento histórico: Vida e fama de Pelé.

Pelé faz propaganda de baterias.

\section{Página 17}

Pelé faz propaganda de declaração de imposto e da produção de ternos de seu próprio império econômico.

Pelé é abraçado pelo Presidente do República.

Pelé dirige Mercedes.

Pelé deve se apresentar na Organização Internacional dos Trabalhadores em Genebra.

Pelé viaja como Embaixador do Coração a Paris e é recebido em Orly com as honras de um chefe de estado.

Pelé com B.B.

Pelé com a Rainha Elisabeth.

Em 17 de fevereiro entrega Pelé ao enfermo François Duvalier no Haiti uma Ordem brasileira.

O Ministério da Educação e Cultura publica três brochuras para o combate do analfabetismo.

Com poderosas 66 páginas, uma delas se chama "Livro de Matemática" e conduz os alunos à divisão de 15 por 4 .

O Livro de Leitura de poderosas 66 páginas é complementado com 34 páginas de exercícios.

A leitura termina:

- Agora vocês recebem sua carteira profissional, pois os vocês sabem ler e escrever. Vocês podem também receber o direito de voto e trocar seu Certificado do Serviço Militar por um novo, em que está registrado: alfabetizado.

$\mathrm{Na}$ nona lição encontram-se as frases de exercício: 
Pelé spielt Fussball.

Pelé ist der König des Fussballs.

In anderen Lesebüchern finden sich die folgenden Übungen:

Mache ein Kreuz bei dem richtigen Satz:

Pelé ist der König von Brasilien.

Pelé ist der König des Fussballs.

Pelé ist der König von Nord- und Südamerika.

Beantworte die folgenden Fragen:

Der König Pelé: Name.. Geburtsort.. Stand.. Lebensdaten..

1954 wieviele Tore?

1956 trat er in welchen Fussballklub ein?

Die Frage nach der Hautfarbe wird in den Papieren nicht abgeschafft, entschied die Justizkommission der Kammer von Brasilia.

\section{Seite 18}

Das Programm der Alphabetisierungskampagne in Bahia:

Bis zum 17. Februar: Zusammenstellung der städtischen Propagandakommission.

Vom 18. Februar bis zum 5. März: Training der Repräsentanten.

Vom 8. März bis zum 12. März: Hausbesuche.

Vom 6. März bis zum 13. März: Bestimmung von Anzahl und Lokalisierung der Alphabetisierungsposten.

Vom 13. März bis zum 19. März: Ausbildung und Training der Lehrer. - Eine Woche!

Vom 20. März bis zum 27. März: Dokumentation.

Vom 28. März bis zum 4. April: Unterschriften.

- Eine Woche!

Pelé joga futebol.

Pelé é o rei do futebol.

Em outros livros de leitura encontram-se os seguintes exercícios.

Faça uma cruz na frase correta:

Pelé é o rei do Brasil.

Pelé é o rei do futebol.

Pelé é o rei da América do Norte e do Sul.

Responda as seguintes perguntas:

O rei Pelé: Nome .. Local de nascimento .. Estado civil .. Dados pessoais ..

1954 quantos gols?

1956 em que clube ele entrou? $* * *$

A pergunta sobre a cor da pele não será abolida dos documentos, decidiu a Comissão de Justiça da Câmara de Brasilia.

\section{Página 18}

O programa da campanha de alfabetização na Bahia:

Até 17 de fevereiro: composição da Comissão de Propaganda da cidade.

De 18 de fevereiro a 5 de março: treinamento dos representantes.

De 8 de março a 12 de março: visitas às casas.

De 6 de março a 13 de março: determinação do número e da localização dos postos de alfabetização.

De 13 de março a 19 de março: formação e treinamento dos professores. - Uma semana!

De 20 de março a 27 de março: documentação.

De 28 de março a 4 de abril: assinaturas.

- Uma semana! 
Vom 5. April bis zum 15. April: Beginn der Stunden.

Vom 2. April bis zum 3. Mai: Alphabetisierung. Von fünf Monaten Geschäftigkeit entfällt einer auf die Alphabetisierung selbst.

Donnerstag, den 4. März:

Jornal do Brasil:

Heute nachmittag wird das neue Stadio Fonte Nova in Bahia von Staatspräsident Medici und dem Governeur von Bahia Luis Viana Filho feierlich eröffnet.

Bahia spielt um 15 Uhr 15 gegen Flamengo, Vitoria gegen Gremio de Porto Alegre um 17 Uhr 17:15 h.

Die Pforten des Stadions werden um zehn Uhr morgens geöffnet.

Man erwartet, dass mehr als 100000 Zuschauer kommen werden.

Die Eintrittspreise gehen von 2 Cruzeiros bis zu 70 Cruzeiros.

Das Stadion fasst 110000 Personen.

Es ist eines der modernsten von ganz Brasilien und kostete 25 Millionen Cruzeiros.

Schon Stunden vorher ist das Stadion voll.

Neben den Billetabreissern stecken die Leute von innen die Eintrittskarten durch die Gitter, um sie wieder zu verkaufen.

Generäle und ein katholischer Priester betreten die Tribüne.

Die lebensgrosse Peléstatue ist nicht pünktlich fertig geworden.

Die Künstlerin hat das Gipsmodell mit Bronzefarbe angemalt.
De 5 de abril a 15 de abril: começo das aulas.

De 2 de abril a 3 de maio: alfabetização.

De cinco meses de atropelos, um recai sobre a alfabetização em si.

***

Quinta-feira, 4 de março:

Jornal do Brasil:

Hoje à tarde o novo estádio Fonte Nova na Bahia será inaugurado solenemente pelo Presidente da República Medici e pelo Governador da Bahia Luis Viana Filho.

O Bahia joga às $15 \mathrm{~h} 15$ contra o Flamengo, o Vitória contra o Gremio de Porto Alegre às 17 h15.

Os portões do estádio são abertos às dez horas da manhã.

Espera-se que mais de 100.000 espectadores virão.

Os preços da entrada vão de 2 cruzeiros a 70 cruzeiros.

O estádio comporta 110.000 pessoas.

É um dos mais modernos de todo o Brasil e custou 25 milhões de cruzeiros.

$* * *$

Já horas antes o estádio está cheio.

Ao lado dos rasgadores de bilhetes, as pessoas de dentro enfiam as entradas pela grade para vendê-las de novo.

Generais e um padre católico entram na tribuna.

A estátua de Pelé em tamanho real não ficou pronta pontualmente.

A artista pintou o modelo de gesso da cor de bronze. 
Ein Polizist verhüllt der Attrappe das Gesicht mit einem Lappen.

\section{Seite 19}

Präsident Medici fährt in Begleitung von Generälen vor.

Eilig zieht er an einer Kordel.

Der Lappen fällt von der Gipsfigur Pelés.

Eilig klatsch der Präsident.

Die Generäle klatschen.

Der Präsident geht die hundert Meter zur Tribüne zu Fuss.

Als er das Stadion betritt, flattern Hunderte von Tauben über die Menge.

Luis Viana Filho lässt die Pforten des Stadions öffnen.

Tausende strömen herein - das letzte Geschenk des scheidenden Gouverneurs.

Während des zweiten Spiels bricht eine Panik aus.

Die Menschen stürzen von den Tribünen.

Die Lautsprecheranlage funktioniert nicht.

Der Präsident und der Gouverneur heben stumm vor den Mikrofonen die Arme.

An der Strasse, die der Präsidentenwagen passieren muss, liegt ein geopferter schwarzer Hahn - so gross wie ein Rabe.

Die Götter haben bestimmt, dass Präsident Medici das Fussballstadion nicht lebend wieder verlässt.

Die Götter irrten.

Freitag, den 5. März:
Um policial cobriu o rosto da réplica com um pano.

\section{Página 19}

Presidente Medici vai de carro na frente em companhia de generais.

Apressadamente ele puxa um cordão.

O pano cai diante da figura de gesso de Pelé.

Apressadamente o presidente aplaude.

Os generais aplaudem.

O presidente anda os cem metros até a tribuna a pé.

Quando ele entra no estádio, centenas de pombas voam agitando as asas sobre a multidão.

Luis Viana Filho manda abrir os portões do estádio.

Milhares afluem para dentro - o último presente do governador deixando seu cargo.

Durante o segundo jogo eclode um pânico.

As pessoas atiram-se das tribunas.

Os aparelhos de alto-falantes não funcionam.

O presidente e o governador levantam mudos os braços diante dos microfones.

***

$\mathrm{Na}$ rua em que o carro do presidente tem que passar, está um galo preto sacrificado - tão grande quanto um corvo.

Os deuses determinaram que o Presidente Medici não deixasse o estádio de futebol novamente com vida.

Os deuses se enganaram. $\star * \star$

Sexta-feira, 5 de março: 
Jornal do Brasil:

Vier Tote - zwei Kinder, sechs und elf Jahre alt, ein 17jähriges Mädchen, ein Mann - und mehr als 1200 Verletzte.

Die Kapazität des Stadions liegt bei 110000 Personen.

Gestern war es mit ungefähr 150000 Personen besetzt.

Tribuna da Bahia:

Mehrere Faktoren kamen zusammen, um das Unglück auszulösen: Die Erinnerung an das Unglück von Belo Horizonte.

Das Gerücht, die Konstruktion würde 110000 Personen nicht aushalten.

\section{Seite 20}

Mittwoch, den 17. März:

O Cruzeiro:

Die erste Version war, dass ein Flutlicht explodiert sei und die Panik auslöste.

Die zweite Version, der die Polizei und eine Untersuchungskommission mehr Glauben schenken, dass ein Mann durch die Ränge lief und schrie, das Stadion würde einstürzen.

Vorsichtigen Schätzungen nach war das Stadion mit wenigstens 150000 Personen besetzt.

Sonntag, den 4. April:

Tribuna da Bahia:

Der Architekt Diogenes Rebouças, der die Planung für das neue Stadion der Fonte Nova leitete, bestätigte, dass die Kapazität des Stadions 80000 Personen sei und nicht 110 000 Personen, wie die Regierung bei der Eröffnung am 4. März verlauten liess.

Jornal do Brasil:

Quatro mortos - duas crianças, seis e onze anos, uma moça de 17 anos, um homem - e mais de 1.200 feridos.

A capacidade do estádio é de 110.000 pessoas.

Ontem ele estava ocupado por aproximadamente 150.000 pessoas.

Tribuna da Bahia:

Vários fatores concorreram para desencadear o acidente: a lembrança do acidente de Belo Horizonte.

O boato de que a construção não suportaria 110.000 pessoas.

\section{Página 20}

Quarta-feira, 17 de março:

O Cruzeiro:

A primeira versão foi que um holofote teria explodido e disparado o pânico.

A segunda versão, à qual a polícia e uma comissão de inquérito dão mais crédito, que um homem correu e gritou pelas arquibancadas que o estádio iria desmoronar.

Segundo cautelosas estimativas, o estádio estava ocupado com pelo menos 150.000 pessoas.

Domingo, 4 de abril:

Tribuna da Bahia:

O arquiteto Diogenes Rebouças, que dirigiu o planejamento do novo estádio da Fonte Nova, confirmou que a capacidade do estádio seria de 80.000 pessoas e não de 110.000 , como o governo mandou divulgar na inauguração em 4 de março. 
Professora Dona Theresa bittet uns einzutreten:

- Sie sind gerade richtig gekommen.

Heute ist die erste Puxada, die erste Saida, das erste Heraustreten der Novizen aus der Einweihungszelle, Ronko, nach dreiwöchigem Eingeschlossensein.

Professora Theresa führt uns in den kleinen Versammlungsraum, wo auch die Waschmaschine steht.

Die »Töchter«, die Würdenträgerinnen, die Mães aus der Nachbarschaft sehen aus wie Gräfinnen auf einer Wohlfahrtsveranstaltung.

Die drei Trommler, der Spieler des Agogo, wirken wie Ganoven, ein Einäugiger, einer schielt, gläubige Arme, mit den Verzeichnungen des Elends.

Die Gräfinnen tanzen.

Scheren werden in die Einweihungszelle hineingelangt.

\section{Auf die Türen!}

Drei geschorene Mädchen kommen heraus, über und über mit weissen Kalkpunkten versehen.

Sie bewegen sich traumwandlerisch in schwerer Trance.

Das eine Mädchen ist etwa acht Jahre alt, das zweite um die fünfzehn, die dritte, die Mutter der Kleinen, ist älter.

Sie tragen alle lange, weisse Spitzenhosen, darüber einen Rock. Die Brüste mit Tüchern weggeschnürt.

\section{Seite 21}

Raffiaschnüre an den nackten, bepunkteten Armen.

Auf dem bepunkteten Schädel eine kleine Kalkpyramide.
- Os Senhores chegaram na hora certa.

Hoje é a primeira Puxada, a primeira Saida, a primeira saída pública das noviças da cela de iniciação, Roncó, após três semanas de reclusão.

Professora Theresa nos conduz à pequena sala de reunião, onde também fica a máquina de lavar.

As «filhas», as dignitárias, as Mães da vizinhança parecem condessas de um evento beneficente.

Os três tocadores de tambor, o tocador de agogô, parecem malandros, um caolho, um é vesgo, pobres fiéis, com as deformidades da miséria.

As condessas dançam.

Tesouras são colocadas para dentro da cela de iniciação.

Abram-se as portas!

Três meninas raspadas saem para fora, marcadas por todo o corpo com pontos brancos de giz.

Elas se movimentam sonambulamente em profundo transe.

Uma das meninas tem cerca de oito anos de idade, a segunda cerca de quinze, a terceira, a mãe da pequena, é mais velha.

Elas vestem todas calças compridas de renda branca, por cima uma saia. Os peitos com panos amarrados, para disfarçá-los.

\section{Página 21}

Cordas de ráfia nos braços nus, pontilhados.

Sobre o crânio pontilhado, uma pequena pirâmide de giz. 
An der Stirn ist mit Bindfaden eine rosa Feder befestigt worden.

Jede muss sich zweimal bäuchlings auf eine Matte legen.

Professora Theresa schüttelt das Adja, einen rasselnden Silberkonus, über ihnen.

Die Novizen tanzen der Gemeinde die Gesten ihres Gottes vor.

Es sind Oxum, die Maria des Wassers, Oxossi, der Heilige Sebastian, Obaluae oder Omolu, der Heilige Rochus und der Heilige Lazarus.

Die drei werden geschlossenen Auges in ihre Zelle zurückgeführt.

Die Gemeinde fällt nun in nicht ganz seriöse Nachmittagstrancen.

Ein kindischer, betteliger Zwischenzustand folgt auf das Ergriffensein durch die Götter es dreht sich vor allem um den Erwerb von Bier, Bonbons und Nadelgeld.

Zum Schluss tanzen nur noch die Männer mit den übertriebenen effeminierten Sexualgesten der Normalen.

Zwei Wohlfahrtsgräfinnen finden sich in einem glühenden Kuss.

P. ist wieder dabei, seine Pflanzenkartei zu ordnen.

Er hat denselben Batikstoff um die Hüften und es gibt die gleiche Batida und derselbe schöne, schweigsame Junge sitzt daneben.

$P$. hat in Afrika einen grossen Teil der Pflanzen notiert, die von den Yoruba zu Heilzwecken benützt werden.

- Für jede Pflanze gibt es eine oder mehrere Zauberformeln, Silben, die auch in dem Namen der Pflanze enthalten sind.
Na testa foi presa com barbante uma pena rosa.

Todas têm que se deitar duas vezes de barriga para baixo sobre uma esteira.

Professora Theresa sacode o Adja, um cone de prata com som de chocalho, sobre elas.

As noviças dançam para a comunidade os gestos de seu Deus.

São Oxum, a Maria da Água, Oxóssi, o São Sebastião, Obaluaê ou Omulu, o São Roque e o São Lázaro.

As três são conduzidas de olhos fechados de volta para sua cela.

A comunidade cai agora em não muito sérios transes vespertinos.

Um estado intermediário infantil, pedinte, vem depois de serem tomados pelos deuses - tudo gira, sobretudo, em torno da aquisição de cerveja, balas e dinheiro para os alfinetes. ${ }^{30}$

Por fim dançam só os homens, com os exagerados e efeminados gestos sexuais dos normais.

Duas condessas beneficentes encontram-se num beijo ardente.

***

P. está de novo organizando seu fichário de plantas.

Ele tem o mesmo pano de Batik em volta dos quadris e tem a mesma Batida* e o mesmo belo, calado jovem está sentado ali perto.

P. anotou na África uma grande parte das plantas que são utilizadas pelos lorubás para fins de cura.

- Para cada planta há uma ou várias fórmulas mágicas, sílabas, que também estão contidas no nome da planta. 
Für die Heilwirkung scheint die Zauberformel wichtiger zu sein als der Chemismus der Pflanze.

Der Zauberspruch kann die Wirkung der Pflanze angeblich modifizieren.

Ist die benötigte Zaubersilbe nicht in dem Namen der Pflanze enthalten, die man zur Hand hat, und will man sie dennoch benützen, wird der Name geändert.

-Es gibt 16 Grundformeln für die Zaubersprüche, die zu 16 mal 16 - 4 mal 4 mal 4 mal 4 - Varianten gebraucht werden.

Aus den 16 Grundformeln weissagt man auch.

Es ergibt sich eine Verbindung zur Geomantie, der Kunst der Chinesen und Araber, aus Linien im Sand wahrzusagen.

Sie wurde im 16. Jahrhundert auch in Europa geübt.

-Vielleicht eine Verwandtschaft zum I Ging.

\section{Seite 22}

-Die Priester haben eine genaue pharmakologische Kenntnis der verwendeten Pflanzen.

Ein französicher Arzt beobachtete in Brasilien, dass die Negerpriester Erregungszustände mit Sabicea calycina behandelten;

in Indien, stellte er später fest, verwendete man dazu Rauwolfia sp.;

In Afrika, beobachtete er schliesslich, benützten die Yoruba sowohl Sabicea sp. als auch Rauwolfia sp.

Ich bemerke, dass die Revolution der modernen Psychiatrie vor zwanzig Jahren durch Deniker und Delay in Paris mit Reserpin ausgelöst wurde, einem Medikament, das man aus Rauwolfia serpentine gewann.
Para o efeito de cura parece que a fórmula mágica é mais importante que o quimismo da planta.

A palavra mágica pode modificar o efeito da planta supostamente.

Não estando a sílaba mágica precisada contida no nome da planta que se tem à mão, e querendo-se, no entanto, usá-la, o nome será mudado.

- Há 16 fórmulas básicas para as palavras mágicas, que são utilizadas em 16 vezes $16-4$ vezes 4 vezes 4 vezes 4 - variantes.

A partir das 16 fórmulas básicas pode-se predizer o futuro também.

Resulta daí uma ligação com a geomancia, a arte dos chineses e árabes de predizer a fortuna das linhas na areia.

Ela foi exercida no século 16 também na Europa.

-Talvez um parentesco com o I Ching.

\section{Página 22}

- Os sacerdotes têm um conhecimento farmacológico exato das plantas utilizadas.

Um médico francês observou no Brasil, que os sacerdotes negros tratavam estados de agitação com Sabicea calycina;

na Índia, ele constatou mais tarde, utiliza-se para isso Rauwolfia sp;

$\mathrm{Na}$ África, observou ele finalmente, usavam os Iorubás tanto Sabicea sp. quanto Rauwolfia sp.

Eu comento que a revolução da psiquiatria moderna foi desencadeada há vinte anos por Deniker e Delay em Paris com Reserpina, um medicamento obtido de Rauwolfia serpentina. 
P. glaubt nicht an die Wahrsagekunst der Priester des Candomble.

- Wenn ich daran glauben würde, könnte ich Dummheiten machen.

Er ist Babalorixa, ein hoher Würdenträger der Yoruba, er hat sich vom Stamm der Ketou einweihen lassen und darf aus dem Kpele, einer Art Kette aus halben, holzigen Früchten, wahrsagen.

Vor 28 Jahren kam er als Fotograf nach Bahia.

In Fazenda Grande do Retiro zerren uns die Kinder zu einem Centro Spiritista.

Die Leiterin ist krank.

-Ich bin 47. Ich habe 7 Kinder zu ernähren. Mein Mann ist tot. Ich bin nervös. Müde. Ich gebe keine Feste für die Götter mehr.

Sie zeigt uns ein Medikament von Ciba, «Sergipa!», das sie gegen den hohen Blutdruck, der sie nervös macht, einnimmt.

Es handelt sich um ein Rauwolfiapräparat.

-Wo ist der nächste Candomblé?

-Ein paar Strassen weiter. Bispo de Paris - der Bischof von Paris. Er gibt sein Fest im April.

-In Rio beten die Leute heutzutage nur noch den Teufel an.

Die Wohnhäuser um den Tempel sind aus Lehm. Er wird von einem feinen Gerüst aus Ästen gehalten.

Die Häuser sind sehr reinlich. In einem steht ein neuer Gasherd und zur Verschönerung der Kopf eines Perückenmachers.

Früher durften in den Yorubakulten von Bahia keine Männer tanzen, das heisst, von den Göttern besessen, »geritten« werden.
P. não acredita na arte da predição dos sacerdotes do candomblé.

- Se eu acreditasse nisso, eu poderia fazer besteiras.

Ele é Babalorixá, um alto dignitário dos lorubás, ele se iniciou na nação Ketu e pode predizer a fortuna a partir do quelê, um tipo de colar de metades de frutos lenhosos.

Há 28 anos ele veio como fotógrafo para a Bahia.

$* * *$

Na Fazenda Grande do Retiro, as crianças nos arrastam a um centro espírita.

A dirigente está doente.

-Eu tenho 47 anos. Eu tenho 7 filhos para alimentar. Meu marido está morto. Eu estou nervosa. Cansada. Eu não dou mais nenhuma festa para os deuses.

Ela nos mostra um medicamento da Ciba, "Sergipa!", que ela toma contra a pressão sanguínea alta que a deixa nervosa.

Trata-se de um preparado Rauwolfia.

-Onde fica o candomblé mais próximo?

-Algumas ruas mais adiante. Bispo de Paris* - 0 Bischof von Paris. Ele dá sua festa em abril.

-No Rio as pessoas hoje em dia só adoram o diabo.

As casas residenciais ao redor do templo são de barro. Ele é sustentado por um fina de estrutura de galhos.

As casas são muito asseadas. Em uma tem um novo fogão a gás e para o embelezamento a cabeça de um fazedor de perucas.

Antigamente homens não podiam dançar nos cultos lorubás da Bahia, isso quer dizer, serem possuídos, „cavalgados" pelos deuses. 
Die ersten Ausnahmen waren Homosexuelle, also weiblichere Männer, denen man hier, wie in anderen schamanistschen Kulten auch, eine besondere Empfänglichkeit für Götter nachsagte.

\section{Seite 23}

Der Schluss: Pai de Santo, Filho de Santo, Priester, Eingeweihter gleich Homosexueller, also: Tunte, Trine, Bicho, Tier, wird in Bahia sofort gezogen.

Bispo de Paris lässt sich mit zwei Frauen fotografieren - er will wohl das gängige Vorurteil in seinem Fall entkräften.

Er weist uns weiter zu Professor A.

Der hat ein üppiges Gotteshaus.

Am Sims steht die Zulassungsnummer des Candomblévereins.

Es ist die falsche Offenheit vieler Päderasten, die ihre wesentlichen Neigungen verbergen müssen und sich deshalb in unwesentlichen Details überkorrekt und offenherzig geben.

Er hat im Garten einen Altar für die Jungfrau Maria, für die Göttin Jemanha errichtet:

Seeigel und weisse Korallen.

Im Haus freche Jungen, Fernsehen und Volkslexika.

Der Marxist aus dem Nordosten:

-Die «Arbeiten» der Pais de Santo bringen viel Geld. Es kostet Tausende, um jemanden auf magische Weise töten zu lassen. Ich habe Leute auf Grund solcher "Arbeiten « sterben sehen. Es fängt mit geschlachteten Tieren und Kerzen an, die man vor die Tür des Opfers stellt.

- Die Beerdigung eines Priesters ist sehr eindrucksvoll. Der Trauerzug geht immer zwei Schritte voran und einen zurück.
As primeiras exceções foram homossexuais, ou seja, homens mais femininos, aos quais aqui, como em outros cultos xamanísticos também, é atribuída uma especial receptividade para os deuses.

\section{Página 23}

A conclusão: Pai de Santo*, Filho de Santo*, sacerdote, iniciados igual a homossexual, então: Maricas, Viadinho, Bicho*, Bicha, é sacado imediatamente na Bahia.

Bispo de Paris se deixa fotografar com duas mulheres - ele quer talvez retirar a força do preconceito corrente no seu caso.

Ele nos encaminha ao Professor A.

Esse tem uma casa de santo luxuosa.

Na cornija está o número do credenciamento da associação de candomblé.

É a falsa abertura de muitos pederastas que têm que esconder suas tendências essenciais e se mostram por isso em detalhes não essenciais supercorretos e de coração aberto.

Ele construiu no jardim um altar para a Virgem Maria, para a Deusa lemanjá:

Ouriços-do-mar e corais brancos.

$\mathrm{Na}$ casa jovens atrevidos, televisão e enciclopédias populares.

***

O marxista do Nordeste:

- Os "trabalhos" dos Pais de Santo trazem muito dinheiro. Custa milhares para mandar matar alguém de forma mágica. Eu vi pessoas morrerem por causa desses "trabalhos". Isso começa com animais abatidos e velas que se colocam na porta da vítima.

- O enterro de um sacerdote é muito impressionante. O cortejo fúnebre anda sempre dois passos para frente e um para trás. 
Die Beerdigung von Meneninha de Gantois hat eine Woche gedauert. Wer einmal in der Totenfeier drin ist, darf sie nicht vor Beendigung verlassen.

Die Gläubigen bilden eine starke soziale Gesellschaft. Da verhungert niemand.

Unsere Vermieterin:

-Mein Mädchen gibt das ganze Geld, das sie bei mir verdient, für den Candomblé aus. Für Liebespulver. Für «Arbeiten» gegen ihre Feinde etc. Essen bekommt sie bei mir. Sie geht schlecht angezogen.

\section{Seite 24}

Ich werde bei dem bekannten Kommunisten angemeldet.

Er hat aus politischen Gründen in seiner Jugend im Gefängnis gesessen.

Er äussert noch immer harte Worte über das Elend in der Stadt.

Er bewohnt ein schönes, kühles Grundstück auf einem Hügel in Meernähe.

Tropische Bäume quellen aus einem gepflegten Garten.

Hübsche Kacheln sind an der Aussenmauer angebracht.

Auf hübschen Kacheln steht neben der Eingangstür der Hinweis auf eine zweite Tür:

- Dienstboteneingang.

Die Dienstmädchen, Raumpflegerinnen, Ammen, Wäscherinnen, Köchinnen verdienen zwischen 50 und 200 Cruzeiros im Monat zwischen 34 und $133 \mathrm{DM}$, bei Unterkunft und voller Verpflegung.

Das Dienstmädchen der Konsulin hat von ihrem ersten Freund zwei Kinder.
O enterro de Menininha de Gantois durou uma semana. Uma vez dentro da celebração dos mortos, não pode deixá-la antes do encerramento.

Os fiéis formam uma forte sociedade solidária. Lá ninguém morre de fome.

Nossa senhoria:

-Minha empregada gasta todo o dinheiro que ela ganha comigo no candomblé. Em pó de amor. Em "trabalhos" contra inimigos etc. Comida ela não recebe na minha minha casa. Ela anda mal vestida.

\section{Página 24}

Eu sou anunciado ao conhecido comunista.

Ele esteve na prisão por motivos políticos na sua juventude.

Ele exprime ainda palavras duras sobre a miséria na cidade.

Ele habita um belo, fresco terreno sobre um morro nas proximidades do mar.

Árvores tropicais brotam de um jardim bem cuidado.

Bonitos azulejos estão assentados no muro externo.

Sobre bonitos azulejos está escrito o aviso ao lado da porta de entrada, apontando uma segunda porta:

- Entrada de serviço.

$* * *$

As empregadas, arrumadeiras de quarto, amas, lavadeiras, cozinheiras ganham entre 50 e 200 cruzeiros por mês - entre 34 e 133 marcos, com moradia e alimentação completa.

A empregada da consulesa tem dois filhos do seu primeiro namorado. 
Als sie inm langweilig wurde, schmiss er sie raus.

Er hat eine andre Freundin; sie hat einen anderen Freund.

Sie ist im achten Monat schwanger.

Sie lieh sich von der Konsulin 1000 Cruzeiros, sie will sich ein eigenes Häuschen kaufen - ein Häuschen aus Lehm und Ästen, um mit den Kindern unabhängig von der Gnade ihrer Freunde zu sein.

\section{Professora Theresa sagt:}

-Eigentlich dauert die Einweihung drei Monate. Aber hier sind die Leute arm und können nicht so viel Geld aufbringen. Sie können die Arbeit nicht drei Monate verlassen, wenn sie Arbeit haben.

Da müssen wir uns mit drei Wochen begnügen.

Die zweite Puxada verläuft wie die erste.

Die Novizen haben heute farbenprächtigere Kleider an als gestern.

Die dunkle Haut ist mit gelben, himmelblauen, rosa Punkten bemalt.

Die Mutter des achtjährigen Mädchens wird von ihrem Orixa, ihrem Gott, ergriffen.

Ein Würdenträger spricht ihr auf die kultisch kindische Weise zu:

\section{Seite 25}

- Es ist das Beste so.

- Du musstest die Kleine hierherbringen. Jetzt wird sie gesund werden und in die Schule gehen können.

Ich glaube, Theresa ist stolz, dass Leonore sie und ihre Zeremonien fotografiert; der Gemeinde gegenüber tut sie so, als wäre es ihr lästig.
Quando ele se aborreceu dela, ele a jogou fora.

Ele tem uma outra namorada; ela tem um outro namorado.

Ela está grávida no oitavo mês.

Ela tomou emprestado da consulesa 1.000 cruzeiros, ela quer comprar uma casinha própria - uma casinha de barro e galhos, para com as crianças ser independente da boa vontade de seus namorados.

***

Professora Theresa diz:

- Na realidade a iniciação dura três meses. Mas aqui as pessoas são pobres e não podem levantar tanto dinheiro. Elas não podem abandonar o trabalho por três meses, quando elas têm trabalho.

Aí nós temos que nos contentar com três semanas.

A segunda puxada ocorre como a primeira.

As noviças estão vestindo hoje vestidos de cores mais esplêndidas que ontem.

A pele escura é pintada com pontos amarelos, azul celeste, rosa.

A mãe da menina de oito anos é tomada pelo seu Orixá, seu Deus.

Um dignitário fala com ela da maneira ritualística infantil:

\section{Página 25}

- É melhor assim.

- Você tinha que trazer a pequena aqui. Agora ela vai ficar com saúde e poder ir à escola.

Eu acho que Theresa está orgulhosa que Leonore fotografe a ela e suas cerimônias; para a comunidade ela faz como se isso para ela fosse incômodo. 
Das achtjährige Mädchen hatte vor der Einweihung epileptische Anfälle.

P. führt uns zu Olga de Alaketu, der Diva unter den Mães de Santo. Sie wird bemüht, wenn Botschafter den Candomblé kennenlernen wollen oder Jean Paul Sartre mit Simone de Beauvoir Bahia besucht.

- Sie ist eine Königstochter. Man weiss, dass hohe Würdenträger der Ketu als Sklaven hier Land erworben haben.

Sie spricht wenig von der Religion.

Sie redet im wesentlichen davon, dass man in Rio mehr Geld mit dem Candomblé verdienen kann als in Bahia.

Sie ist zu $\mathrm{P}$. eher unterwürfig. Leonore wird von ihr geschnitten.

Sie hat irgendein heiliges Geschäft mit P. und beide tuscheln weihevoll miteinander.

Ihr Sohn, hübsch, sexy, arrogant, 19, hat schon einen Bauch.

P. sagt:

- Es ist ein afrikanischer Prinz.

Wir begleiten P. zu dem windschiefen Candomblé von Vincente.

Vincente gibt vor, Ewe zu sprechen.

Er feiert einmal im Jahr einen Festzyklus für Ogum, den Kriegsgott, den Gott des Eisens, der Metallarbeiter und der Taxifahrer.

Vincente zeigt uns Ogums Altar.

Alles strahlend Weiss. Stockfische, Widderköpfe, ein Hundekopf.

Das Fotografieren ist verboten:

- Der Heilige isst.
A menina de oito anos tinha antes da iniciação ataques epilépticos.

***

P. no conduz a Olga de Alaketu, a Diva dentre as Mães de Santo*. Ela é requisitada quando embaixadores querem conhecer o Candomblé ou Jean Paul Sartre com Simone de Beauvoir visita a Bahia.

- Ela é uma filha de rei. Sabe-se que altos dignatários do Ketu como escravos aqui adquiriram terra.

Ela fala pouco da religião.

Ela fala essencialmente que no Rio pode-se ganhar mais dinheiro com o Candomblé que na Bahia.

Ela é em relação a $P$. principalmente submissa. Leonore é cortada por ela.

Ela tem um negócio sagrado qualquer com $\mathrm{P}$. e ambos susurram cheios de solenidade um com o outro.

Seu filho, bonito, sexy, arrogante, 19, já tem uma barriga.

P. diz:

- Ele é um príncipe africano.

Nós acompanhamos P. ao tortuoso Candomblé de Vincente.

Vincente afirma que fala Ewe.

Ele celebra uma vez por ano um ciclo de festas para Ogum, o Deus da Guerra, o Deus do Ferro, - Deus dos Metalúrgicos e dos Motoristas de Táxi.

Vincente nos mostra o altar de Ogum.

Tudo radiantemente branco. Bacalhaus, cabeças de carneiro, uma cabeça de cachorro.

Fotografar é proibido.

- O Santo está comendo. 


\section{Seite 26}

Die Kellnerin im Novo Continental sagt:

- Es ist nichts Besonderes, dass Kinder eingeweiht werden.

- Wenn der Heilige es so bestimmt!

- Ein Bekannter von mir ist mit einem Jahr und sieben Monaten eingeweiht worden.

- Je früher, desto besser; dann wird der Schock leichter überwunden.

- Welcher Schock?

Sie antwortet nicht.

***

Die Opfertiere bei Vincente fangen an zu verwesen, in den Tellern wächst Schimmel auf.

Vincente wünscht sich aus Europa einen echten Wolfszahn, Christrose, Lorbeerblätter und Salbei.

P. nimmt diese Wünsche nicht sehr ernst:

- Das sind so Sachen, die hat er in den modernen Zauberbüchern gelesen.

Vincente zeigt uns ein perlenbesticktes Kultkleid.

Ein Geistlicher mit einer disproportionierten weissen Sportmütze kommt.

Vincente empfängt inn ehrerbietig.

P. sagt:

-Vincente hat mit dem afrikanischen Prinzen ein zartes Verhältnis. Es gilt als besonders männlich, einen Priester zu begatten.

\section{Professora Theresa erklärt:}

- Nachdem der Orixa das erste Mal in den Kopf eines Mädchens gestiegen ist, wird es in ein weisses Wolltuch gehüllt und ins Ronko
Página 26

A garçonete no Novo Continental diz:

- Não há nada de especial, que crianças sejam iniciadas.

- Quando o santo assim o determina!

- Um conhecido meu foi iniciado com um ano e sete meses.

- Quanto mais cedo, melhor; então o choque é mais fácil de superar.

- Que choque?

Ela não responde.

$* * *$

Os animais de sacrifício na casa de Vicente começam a se decompor, nos pratos cria-se bolor.

Vincente deseja para si da Europa um verdadeiro dente de lobo, rosa-de-cristo, folhas de louro e sálvia.

P. não leva os desejos muito a sério:

- Essa são coisas que ele leu nos modernos livros de magia.

Vincente mostra-nos uma roupa ritualística bordada com pérolas.

Um sacerdote com um desproporcional boné esportivo branco chega.

Vincente o recebe com tributos de honra.

P. diz:

-Vincente tem com o príncipe africano uma relação delicada. Considera-se como especialmente viril copular com um sacerdote.

Professora Theresa explica:

- Depois que o Orixá subiu a primeira vez na cabeça da menina, ela é envolta em um pano branco de lã e levada para o Roncó. Ela entra 
gebracht. Es gerät jetzt in eine leichte Trance - Ere. Es muss sich drei Wochen ausruhen. Dann wird das Opfer für den Gott Exu gemacht - Ebo. Drei Tage später das Opfer für die Eguns, für die Toten, nachts um elf oder zwölf. Drei Tage später die Obrigação da Consciencia - die Zeremonie des Bewusstseins zu verlieren. Da wird das Bewusstsein zerbrochen. Honig. Weisses Maismehl. Weisses

\section{Seite 27}

Acaçu - Hura crepitans - , Stroh Von der afrikanischen Küste, weisses Porzellan, ein weisser Tontopf. Drei Tage später Bori, die Haare werden abrasiert. Drei Monate nach der ersten Trance $\mathrm{O}$ Nome, der Name. Sieben Tage vor dem Namen beginnen die Puxadas, die Saidas, das Heraustreten der Mädchen aus dem Ronko. An einem Montag, sieben Tage vor dem Namen wird dem Exu des Hauses geopfert. Am Morgen vor dem Namen das Blutbad. Der Name ist immer am Sonntag drauf die Quitanda. Drei Monate später wird das Kele abgemacht. Ein Jahr spatter die Obrigação do Ano, die Zeremonie nach dem ersten Jahr. Sieben Jahre später erhält die Tochter das Deca; sie kann jetzt selbst einen Candomblé aufmachen und Novizen einweihen und die Kaurimuscheln zur Wahrsagung werfen.

***

- Die heiligen Männer und Frauen, die einen Candomblé leiten, brauchen natürlich nicht mehr zu arbeiten. Die "Arbeiten « bringen tatsächlich oft mehrere tausend Cruzeiros ein. Vincente hat einen Landsitz und ein schönes Auto.

- Olga de Alaketus Sohn ist angeblich Fotograf. Aber als Sohn von Olga braucht er natürlich nicht zu arbeiten. Er ist das Patenkind agora em um leve transe - Erê. Ela tem que descansar por três semanas. Então é feito sacrifício para o Deus Exú - Ebó. Três dias mais tarde, o sacrifício para os Eguns, para os mortos, à noite às onze ou doze. Três dias mais tarde a Obrigação da Consciencia - a cerimônia da perda da consciência. Aí a consciência é quebrada. Mel. Farinha de milho branca. Acaçu

\section{Página 27}

Branco - Hura crepitans - palha da costa africana, porcelana branca, uma panela de barro branca. Três dias mais tarde, Bori, os cabelos são todos raspados. Três meses depois do primeiro transe, o nome. Sete dias antes do nome começam as puxadas, as Saidas ${ }^{*}$, a vinda das meninas para fora do roncó. Em uma segunda-feira, sete dias antes do nome, sacrifica-se para o Exú da casa. Na manhã antes do nome, o banho de sangue. O nome é sempre no domingo após a Quitanda. Três meses mais tarde, o quelê é retirado. Um ano mais tarde, a Obrigação do Ano, a cerimônia depois do primeiro ano. Sete anos mais tarde recebe a filha o decá: ela pode agora abrir um Candomblé e iniciar noviças e jogar conchas de cauri para a predição.

P.:

- Os homens e mulheres santos, que dirigem um Candomblé, não precisam mais trabalhar, naturalmente. Os "trabalhos" trazem realmente com frequência vários mil cruzeiros. Vincente tem uma propriedade rural e um belo carro.

- O filho de Olga de Alaketu é, supostamente, fotógrafo. Mas como filho de Olga, ele naturalmente não precisa trabalhar. Ele é 
eines Universitätsprofessors, eines Soziologen.

- Die Mães und Pais sind sehr arrogant. Der Candomblé verschafft innen einen unermesslichen Einfluss. Sie sollten sich eigentlich um das Wohlergehen ihrer Gemeinde kümmern und einige tun das auch, aber die meisten nützen die Gläubigen einfach aus.

- Es gab einen Pai de Santo, der hiess «24 horas» - seine unheilbringenden Arbeiten mussten innerhalb von 24 Stunden gewirkt haben, sonst brauchte der Klient nicht zu bezahlen. «24 horas» ist reich gestorben.

- Alle Pais de Santo sind wohl homosexuell.

\section{Seite 28}

Morgens um acht zur Opferzeremonie bei Vincente.

Die Töchter der Heiligen bügeln.

Das ewige Bügeln des Candomblés.

Hühner an Tischbeinen festgebunden.

In einem Hinterhof, den Augen der Profanen entzogen, werden die Opfertiere geschlachtet.

Hühner und eine Ziege.

Das Blut wird in Schüsseln an uns vorbeigetragen.

Der »Würdenträger des Messers « kommt mit blutigen Armen.

Beim abendlichen Fest tanzt ein Mädchen zum Rhythmus Agabi.

Eine halbe Stunde lang zum weissglühenden Wirbeln der Trommeln.

Das New York City Ballet wirkte im Vergleich dazu wie eine Volkstanzgruppe. afilhado de um professor universitário, um sociólogo.

- As Mães e Pais são muito arrogantes. O Candomblé lhes proporciona uma influência imensurável. Eles deveriam na realidade cuidar do bem-estar de sua comunidade e alguns também o fazem, mas a maioria simplesmente explora os fiéis.

- Havia um Pai de Santo* que se chamava "24 horas" - seus trabalhos portadores de desgraça deveriam ter efeito dentro de 24 horas, senão o cliente não precisava pagar. " 24 horas" morreu rico.

-Todos os Pais de Santo* são, provavelmente, homossexuais.

\section{Página 28}

Pela manhã, às oito, para a cerimônia de sacrifício no Vincente.

As filhas dos santos estão passando roupa.

O eterno passar-roupas do Candomblé

Frangos amarrados nos pés de mesa.

Em um pátio interior, retirados aos olhos dos profanos, os animais de sacrifício são abatidos.

Frangos e uma cabra.

O sangue é carregado diante de nós em tigelas.

O „dignatário da faca“ vem com os braços ensanguentados.

$\mathrm{Na}$ festa noturna dança uma menina ao ritmo do agabi.

Durante uma meia hora, ao rodopiar brancoardente dos tambores.

O New York City Ballet, em comparação, pareceria um grupo de dança popular. 
Der frühbäuchige Sohn von Olga de Alaketu macht die heiligen Mädchen mit seiner Trommel an. Was für ein gleisnerischer Junge.

Wenn er die Macht eines afrikanischen Prinzen hätte?!

Die Mädchen strecken sich beim Tanzen auf eine obszöne Art die Zunge heraus.

Eine Tochter fällt Leonore um den Hals und auf die Hasselblad.

Ein Würdenträger lockt mich zu einem Glas Limonade in sein Haus.

Er ist Karnavalmusiker und er schwärmt von einem Candomblé, wo man neuerdings ein Klavier aufgestellt hat.

Herr R., der Besitzer des grössten Fotogeschäftes am Platz, der den Kollegen aus Neid die Filme beschädigt, hat 1600 Dollar bezahlt, um das Blutbad in einem Candomblé zu fotografieren.

Er nennt den Namen des heiligen Hauses nicht.

Wir warten auf den Beginn der dritten Puxada, zwischen Fernseher, Volkslexikon, Plastikblumen, Nähmaschine, Plastikcouch.

Die Trommler machen unanständige Bemerkungen und tuscheln vom Verkauf einer Pistole.

\section{Professora Theresa sagt:}

-Die Novizinnen fühlen sich wohl in ihrer Zelle. Die lawo haben es doch gut die 21 Tage über.

\section{Seite 29}

Heute geht alles etwas geschwind.
O filho de Olga de Alaketu, com uma barriga precoce, flerta com as meninas sagradas com seu tambor. Que moço de falso brilho hipócrita.

Se ele tivesse o poder de um príncipe africano?!

As meninas esticam a língua para fora na dança, de um um modo obsceno.

Uma filha agarra o pescoço de Leonore e a câmera fotográfica Hasselblad.

Um dignatário me atrai para um copo de limonada para dentro de sua casa.

Ele é músico de carnaval e está entusiasmado com um Candomblé, onde recentemente se colocou um piano.

Sr. R., o proprietário da maior loja de fotografia na praça, que danifica por inveja os filmes dos colegas, pagou 1.600 dólares para fotografar 0 banho de sangue em um Candomblé.

Ele não designa o nome da casa sagrada.

***

Nós esperamos pelo começo da terceira Puxada*, entre televisão, enciclopédia popular, flores de plástico, máquina de escrever, sofá de plástico.

Os tocadores de tambor fazem observações indecentes e cochicham sobre a venda de uma pistola.

Professora Theresa diz:

- As noviças parecem se sentir bem em suas celas. Sim, as iaôs passam bem durante os 21 dias.

\section{Página 29}

Hoje tudo está um pouco rápido. 
Die drei Novizinnen erscheinen wieder weissbepunktet.

Viel Gekicher.

Kein Gott steigt herab.

Anschliessend noch Gespräche über das Blutbad.

Einen Ziegenbock würde man schon von mir als Gastgeschenk annehmen.

Der Soundso soll sich für 2000 Dollar hergegeben haben, das Blutbad zu fotografieren zu lassen.

Aber der Fotograf und die Zeitschrift seien beschissen worden.

Der Priester hätte einen Mann als Mädchen ausgegeben und nackte Mädchen in Waschschüsseln gestellt.

-Das gibt es doch gar nicht. Jeder, der was davon versteht, weiss das.

$$
\text { P.: }
$$

- Das Geld zur Unterhaltung eines Candomblés, für das gemeinsame Mahl bei den Gottesdiensten etc. kommt zum grossen Teil von begüterten Freunden, die auch Oga, Würdenträger, genannt werden.

- Es ist schon möglich, dass R. 1600 Dollar bezahlt hat, um seine Aufnahmen zu machen. Aber er ist betrogen worden und hat nichts Authentisches fotografiert. Seine Veröffentlichung wimmelt von Fehlern. Das Ganze hat viel Ärger in den Candomblékreisen verursacht.

- Ich brauchte nie etwas zu bezahlen, als ich Aufnahmen machen wollte. Aber je besser ich einige Tempel kannte, desto weniger fotografierte ich und jetzt habe ich es ganz aufgegeben. Es liessen eigentlich immer nur etwas unseriöse Candomblés in Bahia fotografieren.

As três noviças aparecem de novo pontilhadas de branco.

Muita risada abafada.

Nenhum deus baixa.

Por fim, ainda conversas sobre o banho de sangue.

Um bode ainda aceitariam de mim como presente de hóspede.

O Fulano de Tal deve ter se vendido por 2.000 dólares para deixar fotografar 0 banho de sangue.

Mas o fotógrafo e a revista teriam sido sacaneados.

O sacerdote teria apresentado um homem como se fosse moça e colocado moças nuas em bacias de lavagem.

-Isso não existe de jeito nenhum. Cada um que entende um pouco disso, sabe.

***

P.:

- O dinheiro para a manutenção de um Candomblé*, para a refeição comunitária nos cultos religiosos etc. vem em grande parte de amigos abastados, que também são chamados de ogãs, dignitários.

- É bem possível que R. tenha pago 1.600 dólares para fazer suas tomadas fotográficas. Mas ele foi enganado e não fotografou nada de autêntico. Sua publicação formiga de erros. Tudo isso causou muito aborrecimento nos círculos do Candomblé*.

- Eu nunca precisei pagar algo, quando eu quis fazer tomadas fotográficas. Mas quanto mais eu conhecia um templo, menos eu fotografava e agora eu desisti disso totalmente. Na verdade, apenas Candomblés pouco sérios na Bahia se deixam fotografar. 
- Der erste, der eine grosse Reportage über die Candomblés von Bahia gemacht hat, ist Cluzot, Anfang der 50er Jahre.

- Die katholische Kirche ist dem Candomblé gegenüber im Augenblick sehr tolerant. Es gibt Patres, die Bücher über den afroamerikanischen Synkretismus verfassen. Früher hat die Kirche zusammen mit dem Staat die afrikanischen Religionen in Brasilien verfolgt. Die Pais de Santo wurden in Gefängnisse geworfen, die Terreiros, die Kultstätten, zerstört.

- Man weiss immer noch sehr wenig von den Gebräuchen der Afrikaner zur Zeit der Sklaverei. Die Verfolgung des Candomblé

\section{Seite 30}

reicht bis in die jüngste Vergangenheit. Noch der Diktator Getulio Vargas hat Candomblégeistliche verfolgt.

- Heute breitet sich der Candomblé mehr und mehr aus.

- Je traditiosreicher das Haus, desto unauffälliger die Trance. In Afrika bemerkt man oft gar nicht, dass der Gott durch die Trance von seiner Tochter, seinem «Pferd», Besitz genommen hat.

- In Afrika gibt es modern Sekten, die kennen keine genau umrissenen Götter mehr. Dort fallen die Gläubigen in eine sehr wilde Trance und verkörpern dann den Gouverneur oder eine Lokomotive.

Der Reis kostete 1967 0,67 Cruzeiros - 1970 1,12 - 1971 auf der Feira de São Joaquim 1,80 .

Bohnen 1967 0,48 - 1971 1,80.

Maniok 1967 0,18-1971 1,20

Schweinefleisch 1967 2,00 - 1971 4,00
- O primeiro que fez uma grande reportagem sobre os Candomblés da Bahia foi Cluzot, no início dos anos 50.

- A Igreja Católica é muito tolerante em relação ao Candomblé ${ }^{\star}$ no momento. Há padres que escrevem livros sobre 0 sincretismo afroamericano. Antigamente a Igreja, juntamente com o Estado, perseguiu as religiões africanas no Brasil. Os Pais de Santo* foram jogados em prisões, os Terreiros* ${ }^{*}$ os locais de culto, destruídos.

- Ainda se conhece muito pouco sobre os costumes dos africanos no tempo da escravidão. A perseguição do Candomblé

\section{Página 30}

atinge até um passado mais recente. Ainda o ditador Getúlio Vargas perseguiu os religiosos do Candomblé.

- Hoje o Candomblé se expande cada vez mais.

- Quanto mais cheia de tradição a casa, menos chamativo o transe. Na África, muitas vezes não se nota que o deus tomou posse de sua filha, de seu "cavalo".

- Na África há seitas modernas que não conhecem deuseus exatamente bem definidos. Lá os fiéis caem em um transe muito selvagem e incorporam então o governador ou uma locomotiva.

***

O arroz custava em 1967 0,67 cruzeiros - 1970 1,12 - 1971 na Feira de São Joaquim 1,80.

Feijões 1967 0,48 - 1971 1,80

Mandioca 1967 0,18 - 1971 1,20.

Carne de porco 1967 2,00 - 1971 4,00. 
Ein Ei 1967 0,10 - 1971 0,19.

Ein Liter Milch 1967 0,15 - 1971 0,70.

Jornal do Brasil:

In den ersten drei Monaten des Jahres verteuerten sich die Grundnahrungsmittel um 10 Prozent.

Wir gehen mit Professora Theresa auf den Markt von São Joaquim, Opfertiere kaufen.

Es ist der Volksmarkt und die Nahrungsmittel werden den Armen im Dreck angeboten.

Eine Ziege kostet 50 Cruzeiros, ein Angolahuhn 10 Cruzeiros, eine Taube acht.

Es werden benötigt:

3 Ziegen,

3 Angolahühner,

3 Hühner,

3 Enten,

3 weisse Tauben - für jede Novizine ein vierfüssiges Opfertier, und Federvieh, um jedes Bein der Ziegen zu »bedecken«.

\section{Seite 31}

Ich darf die Opferziegen im Volkswagentaxi zum Kulthaus transportieren.

Ich fühle mich im Zentrum der Freundschaft dieser afrikanischen Proletarier.

Sicher, meine ich, werden sie mich morgen an dem faszinierendsten, dem schockierendsten, dem ganz atavistischen - Mühl, Nitsch, Lil Picard - Blutbad teilnehmen lassen und Leonore wird ihre schönsten Fotos machen nicht um die Fabelsumme damit zu verdienen, denn die Fabelsumme, die die Schulden

Um ovo 1967 0,10 - 1971 0,19.

Um litro de leite 1967 0,15 - 1971 0,70.

***

Jornal do Brasil:

Nos três primeiros meses do ano, os alimentos básicos encareceram 10 por cento.

***

Nós vamos com a Professora Theresa ao mercado de São Joaquim*, comprar animais de sacrifício.

É o mercado popular e os gêneros alimentícios são oferecidos aos pobres na sujeira.

Uma cabra custa 50 cruzeiros, uma galinha d'angola 10 cruzeiros, uma pomba oito.

São necessários:

3 cabras,

3 galinhas-d'angola,

3 frangos,

3 patos,

3 pombas brancas - para cada noviça um animal de sacrifício de quatro patas, e animais de penas, para "cobrir" cada perna das cabras.

\section{Página 31}

Eu tenho a permissão de transportar as cabras de sacrifício para a casa de culto no táxi da Volkswagen.

Eu me sinto no centro da amizade desses proletários africanos.

Certamente, penso eu, eles amanhã vão me deixar participar do mais fascinante, o mais chocante, o totalmente atávico - Mühl, Nitsch, Lil Picard - banho de sangue e Leonore vai fazer suas mais belas fotos - não para ganhar uma soma fabulosa com elas, pois a soma fabulosa 
dieser Reise deckte, kann man nicht mit Fotos einbringen.

Ich stelle mir Wunderfotos vor. Leonores Empfindlichkeit und die ganz unverdauliche Bluterei.

Nachmittags die vierte und letzte Puxada. Die Schädel sind heute mit einer teuren, blauen Farbe bemalt.

Eigentlich sollte es echtes Indigo sein.

Aber afrikanisches Indigo ist in Bahia selten geworden.

Die abgeschminkten Mädchen hüpfen im heiligen Raum herum.

Ein neunzehnjähriger Tischler kommt aus dem Innern des Landes, um in der Grossstadt Bahia sein Glück zu machen.

Er findet wochenlang keine Arbeit.

- Ich habe alles kennengelernt. Sogar den Hunger.

Jetzt ist er in einer Möbeltischlerei für weniger als hundert Mark im Monat angestellt. $\mathrm{Er}$ arbeitet 52 Stunden in der Woche, unbezahlte Überstunden nicht gerechnet.

Er wohnt mit zwei Kameranden in einem Verschlag aus Pappwänden.

Morgens bekommt er dort Kaffee und zwei Eier.

Mittags isst er ein Brot.

Abends Bohnen und Reis.

Jeden Abend Bohnen und Reis.

Dafür bezahlt er 25 Cruzeiros in der Woche.

24 Cruzeiros, 16 Mark, bleiben inm im Monat für Liebe, Bildung, Zerstreuung, Kleidung, Zigaretten. que cobriria as dívidas dessa viagem não se pode faturar com fotos.

Eu imagino fotos maravilhosas. A sensibilidade de Leonore e toda a indigesta sangueira.

À tarde, a quarta e última Puxada*. Os crânios estão hoje pintados com uma cara cor azul.

$\mathrm{Na}$ realidade deveria ser um índigo verdadeiro.

Mas índigo africano tornou-se na Bahia raro.

As moças maquiadas pulam ao redor do quarto sagrado.

***

Um marceneiro de dezenove anos vem do interior do estado para fazer sua fortuna na grande cidade da Bahia.

Ele não encontra trabalho semanas a fio.

- Eu conheci de tudo. Até a fome.

Agora ele está empregado numa marcenaria por menos de cem marcos por mês. Ele trabalha 52 horas por semana, sem contar horas extras não pagas.

Ele mora com dois companheiros em um barraco de paredes de papelão.

De manhã ele recebe café e dois ovos lá.

Ao meio-dia, ele come um pão.

À noite feijão e arroz.

Toda noite feijão e arroz.

Ele paga 25 cruzeiros por semana por isso.

24 cruzeiros, 16 marcos, sobram para ele por mês para amor, educação, distração, roupa, cigarros. 
So oft er kann, erbarmt er sich älterer Herren, die sich seiner erbarmen.

\section{Seite 32}

P. sagt:

- Im Grunde ist der Candomblé doch sexfeindlich. Die Einweihungen müssen unter völliger sexueller Abstinenz geschehen. Oft sind in der Einweihungszelle Männer und Frauen gemeinsam - man nennt eine solche Initiationsgemeinschaft das «barco», das Schiff, die Bedingung ist Enthaltsamkeit.

- Die Homosexualität der Pais de Santo wird geduldet, nicht gefördert und wohl doch, auch vom religiösen Standpunkt aus, verurteilt.

Der Gärtner in der VW-Filiale bemerkt:

- Ich habe eine schöne Heilige - uma santa linda.

Er meint damit etwas ganz Unheiliges.

Es ist das erste Mal, dass ich im Umkreis des Synkretismus auf etwas ausgesprochen Priapisches stosse.

Eduardo Ixexa ist der Leiter des einzigen Candomblés der »Nation « Ixexa.

Er ist neunzig Jahre alt und hat eine grosse Warze im Gesicht.

Er vollzieht keine Einweihungen mehr.

- Das ist alles viel zu viel Verantwortung für mich.

Einmal im Jahr singt er - ohne Trommelbegleitung - mehrere Tage lang einen einzigen Festzyklus.

Das Haus ist dem Wald- und Jagdgott Logum Ede geweiht.
Sempre que ele pode, ele se compadece de velhos senhores, que se compadecem dele.

\section{Página 32}

P. diz:

- No fundo, o Candomblé* é, na realidade, inimigo do sexo. As iniciações devem ocorrer sob total abstinência sexual. Com frequência ficam na cela de iniciação homens e mulheres juntos - denomina-se uma tal comunidade de iniciação de o „barco“*, a condição é a abstinência.

- A homossexualidade dos Pais de Santo* é tolerada, não incentivada e, de fato, também, do ponto de vista religioso, condenada.

***

O jardineiro na filial da Volkswagen observa:

- Eu tenho uma santa linda.

Ele quer dizer com isso algo totalmente não sagrado.

É a primeira vez que eu, dentro do círculo do sincretismo, me deparo com algo declaradamente priápico.

***

Eduardo ljexá é líder do único candomblé da"nação" ljexá.

Ele tem 90 anos de idade e tem uma grande verruga no rosto.

Ele não realiza mais nenhuma iniciação.

- Isso é responsabilidade demais para mim.

Uma vez por ano ele canta - sem acompanhamento de tambores - durante vários dias, um único ciclo de festas.

A casa é consagrada ao deus da floresta e da caça, Logum Edé. 
Einige behaupten, Logum Ede sei Alguns afirmam que Logum Edé é bissexual: zweigeschlechtig:

Sechs Monate Jäger im Wald, sechs Monate Nymphe in den Wassern.

Eduardo verneint das entschieden.

- Logum Ede ist als Mann geboren.

- Und wer ist Logum Ede in der katholischen Kirche?

Eduardo lacht. Er will nicht antworten.

- In meinem Haus ist alles öffentlich. Ich mache nichts hinter geschlossenen Türen.

Er zeigt mir das einzige Heiligenzimmer neben der Wohnstube.

- Warum mehrere? - Eins genügt.

Der Altar ist mit kleinen, bunten, elektrischen Birnen geschmückt.

Es beginnt zu regnen und ich muss über die angemessene Zeit hinaus bleiben.

\section{Seite 33}

Wir sitzen in den Nobelsesseln und tauschen taktvolle Belanglosigkeiten.

Eduardo ist der Sohn eines ehemaligen Gouverneurs.

Es wird berichtet, dass er sich stundenlang mit Nigerianern auf Yoruba unterhalten kann - als einziger in Bahia.

Im Cine Pax ein Film über Cangaceiros.

Vor dem Vorspann eine Mordszene; der Tote liegt blutüberströmt auf dem Boden.

Der Mörder erhebt sich mit blutigen Händen und blutiger Kleidung und holt ein nacktes Baby aus dem Korb.

Seis meses caçador na floresta, seis meses ninfa nas águas.

Eduardo nega isso decididamente.

- Logum Edé nasceu homem.

- E quem é Logum Edé na Igreja Católica?

Eduardo ri. Ele não quer responder.

- Na minha casa tudo é público. Eu não faço nada por trás de portas fechadas.

Ele me mostra o único quarto sagrado ao lado da sala de estar.

- Por que vários? - Um basta.

O altar é decorado com pequenas, coloridas, lâmpadas elétricas.

Começa a chover e eu tenho que ficar além do tempo adequado.

\section{Página 33}

Nós estamos sentados nas poltronas nobres e trocamos insignificâncias cheias de tato.

Eduardo é o filho de um antigo governador.

Relata-se que ele pode conversar durante horas com nigerianos em iorubá - como o único na Bahia.

***

No Cine Pax, um filme sobre Canganceiros*.

Antes da apresentação, uma cena de assassinato; o morto está deitado coberto de sangue no chão.

O assassino se ergue com as mãos ensanguentadas e a roupa ensanguentada e apanha um bebê pelado do cesto. 
Im Vorspann wird der Militärpolizei für die freundliche Hilfe beim Drehen gedankt.

Banken haben bei der Finanzierung geholfen.

Eine Folterszene: Einem Mann wird Zentimeter um Zentimeter die ganze Brust aufgeschnitten.

Das ganze Kino brüllt vor Lachen.

Sonntag morgen sollen wir kommen.

Um sechs.

Oder im Morgengrauen.

Die unheimliche Morgenstunde.

Die Mörderstunde.

Um vier finden wir einen Privatwagen, der uns für 20 Cruzeiros hinbringt.

Kein Mensch auf den Strassen.

Picassoschiefe Fassaden.

In der Strassenmitte die Bäche aus Exkrementen.

Von weitem hören wir das Trommeln und die Gesänge.

Die Strassentür ist verschlossen.

Wir klopfen.

- Einen Augenblick! Einen Augenblick!

Wir dürfen rein.

Vor dem Allerheiligsten, dem Ronko, sitzt ein Trommler.

Die Tür zur Einweihungszelle wird einen Spalt geöffnet und eines der letzten Opferhühner hineingelangt.

Professora Theresa kommt mit blutigen Händen heraus und sieht schräg an uns vorbei.

$\mathrm{Na}$ apresentação, agradece-se a polícia militar pela amigável ajuda na rodagem do filme.

Bancos ajudaram no financiamento.

Uma cena de tortura: um homem tem todo o seu peito cortado centímetro por centímetro.

O cinema inteiro ruge de rir. ***

Nós devemos vir domingo de manhã.

Às seis.

Ou no clarear da manhã.

A tenebrosa hora do início da manhã.

A hora do assassino.

Às quatro achamos um carro particular, que nos leva até lá por 20 cruzeiros.

Nenhum ser humano nas ruas.

Fachadas inclinadas à la Picasso.

No meio da rua, os regatos de excrementos.

De longe, ouvimos o bater do tambor e os cantos.

A porta da rua está fechada.

Nós batemos.

- Um momento! Um momento!

Nos deixam entrar.

Diante do mais sagrado, do Roncó, está sentado um tocador de tambor.

Uma fresta da porta que dá para a cela de iniciação é aberta e um dos últimos frangos de sacrifício é colocado para dentro.

Professora Theresa vem para fora com mãos ensanguentadas e olha para nós de soslaio. 


\section{Seite 34}

Ziegen ohne Köpfe, Hühner ohne Köpfe, Enten ohne Köpfe, blutgesprenkelte Tauben ohne Köpfe werden aus dem Ronko zu einem triefenden Haufen geworden.

Punkt sechs, als wir kommen sollten, ist alles vorbei.

- Ja, der Gott hat es so bestimmt.

Unter einem Laken, ein weisser Sechsfüssler, laufen die lawo zum Waschen.

Theresa schlachtet die letzten Hühner in der blutschwimmenden Kammer. Sie ordnet die Köpfe auf Porzelanntellern mit Federn und Öl an.

Abends drängeln sich an die hundert Leute in dem Versammlungsraum. Bevor der geistliche Name insgeheim verliehen wird, müssen die lawo die einzelnen Puxadas mit den verschiedenen Bemalungen wiederholen.

Der Höhepunkt! Der Eintritt ins geistliche Leben! Raketen und Trancen. Auch dabei darf nicht fotografiert werden.

- Sonst geht der Name kaput!

Nun tragen die neuen Töchter zum ersten Mal die Festkleider ihrer Götter.

Das achtjährige Mädchen, Omolu, tritt auf in einem Irrwisch aus Stroh.

Sie ist jetzt der alte Herr der Welt und gebietet über Pocken, Lepra, Pest.

Das Gesicht des Gottes ist pockennarbig, deshalb verbirgt er es unter afrikanischem Stroh.

Montag, den 29. März:

A Tarde:

In der Provinz Minas Gerais wurden nach einer Untersuchung der Lepraabteilung bis zum 31. Dezember letzten Jahres 40921 Leprakranke

\section{Página 34}

Cabras sem cabeça, galinhas sem cabeça, patos sem cabeça, pombas sem cabeça salpicadas de sangue são atirados do Roncó a uma pilha gotejante.

Seis em ponto, quando deveríamos chegar, tudo acabou.

- Sim, o deus assim o determinou.

Sob um lençol, um hexápode branco, as iaôs correm para a lavagem.

Theresa abate as últimas galinhas na câmara nadando em sangue. Ela organiza as cabeças sobre um prato de porcelana com penas e óleo.

À noite, umas cem pessoas se espremem na sala de reunião. Antes que o nome sagrado seja concedido secretamente, as iaôs têm que repetir cada Puxada* com as diversas pinturas.

O ponto alto! A entrada na vida religiosa! Foguetes e transes. Também nesse momento não se pode fotografar.

- Senão o nome estraga!

Agora as novas filhas vestem pela primeira vez os vestidos de festa de seus deuses.

A menina de oito anos, Omulu, se apresenta em um duende de palha.

Ela é agora o velho Senhor do Mundo e rege sobre varíola, lepra, peste.

O rosto do deus é varioloso, por isso ele o esconde sob palha africana.

***

Segunda-feira, 29 março:

A Tarde:

Na província de Minas Gerais foram registrados, após um exame no departamento de lepra, até 31 de dezembro do último ano 40.921 doentes 
registriert. 15999 starben oder verliessen die Provinz.

24992 blieben in Minas Gerais; 4979 in Krankenhäusern, 10235 in ambulanter Behandlung und 9708 in unregelmässiger ambulanter Behandlung.

Der Direktor der Lepraabteilung sagt, es sei absurd, die mittelalterliche sanitäre Verfolgung wieder einführen zu wollen.

\section{Seite 35}

Enrique, der Ingenieur, der in der Stadtverwaltung arbeitet, behauptet, in der Stadt Bahia gebe es nur 1000 Meter Kanalisation.

Im übrigen Sickergruben.

Der Boden der Stadt sei von Abwässern gesättigt und gebe ungefilterte Rinnsale an das Meer ab.

- Die ganze Bucht ist verseucht.

- Eine Titaniumfabrik an der Küste schädigt noch dazu den Fischfang.

- Die Wasserkanppheit in Bahia nimmt zu.

Enrique schätzt die arbeitslosen Asozialen auf etwa 30 Prozent der Bevölkerung.

Im Terreiro Viva Deus eine energische, ungemütliche Mãe de Santo.

- Ich halte sehr auf die Reinheit der Sekte.

- Mein Mann hat gerade ein zweites Haus im Norden, im Ceara eröffnet.

Beim Fest für die Götter ein ziemliches Durcheinander.

Die Mutter kümmert sich nicht um ihre Töchter, die in Trance fallen. Sie schielt nach der Tür, wo einer nach dem anderen, Herren und de lepra. 15. 999 morreram ou deixaram a província.

24.992 ficaram em Minas Gerais; 4.979 em hospitais, $10.235 \mathrm{em}$ tratamento ambulatorial e $9.708 \mathrm{em}$ tratamento ambulatorial irregular.

O diretor do departamento de lepra diz que é um absurdo querer introduzir novamente o rastreamento sanitário medieval.

\section{Página 35}

Enrique, 0 engenheiro, que trabalha na administração da cidade, afirma que na cidade da Bahia só há 1.000 metros de canalização.

De resto, fossas sépticas.

O solo da cidade estaria saturado pelas águas residuais e lançaria regatos não filtrados ao mar.

- Toda a baía está contaminada.

- Uma fábrica de titânio na costa ainda por cima prejudica a captura de peixes.

- A escassez de água aumenta na Bahia.

Enrique avalia os associais desempregados em cerca de 30 por cento da população.

***

No terreiro* Viva Deus*, uma Mãe de Santo* enérgica, desagradável.

- Eu zelo muito pela pureza da seita.

- Meu marido acabou de inaugurar uma segunda casa no norte, no Ceará.

Na festa para os deuses, uma certa confusão.

A mãe não cuida de suas filhas que caem em transe. Ela olha de soslaio para a porta, onde chegam, um após o outro, senhores e damas da 
Damen der Gesellschaft, ankommen, die zum Unterhalt des Tempels beitragen.

Viele «unvorhergesehene» Trancen, die für die nächsten Monate reichlichen Verdienst versprechen.

Nach wildem Gestikulieren bleiben die neu von den Göttern Erwählten steif auf dem Boden liegen und werden - wie in Afrika - in weisse Tücher gerollt und in die geheimen Gemächer der Mutter getragen.

Ich kann von draussen heineinsehen.

Gebimmle und Räucherwerk sollen die Erstarrten wieder zu sich bringen.

Auf jeden Fall hat die Mãe full house.

Die Verwandte einer frisch Verzückten scheint schon vorher Bescheid gewusst zu haben, denn sie brachte gleich alles für die Einweihungszeit Notwendige mit.

Die weissen Würdenträger spielen sich als Saalordner auf, wenn Leonore fotografieren will.

Die Mãe stellt sich unter Protesten ins günstigste Licht und rückt sich das Tuch an der Brust zurecht.

So kann sie das Gesicht der Yorubageistlichen wahren und gleichzeitig ihre Eitelkeit befriedigen.

\section{Seite 36}

Da Leonore das weiss, kann sie fotografieren, ohne jemanden ernstlich zu kränken.

Und als sie das zweite Mal kommt, wird sie sehnsuchtsvoll gefragt, wo ist die Kodak?!

Einer der Ogas von Viva Deus ist ein junger Ingenieur.

Als die Mãe ihn zum Würdenträger bestimmen wollte, verständigte sie ihn, dass der Gott während ihrer nächsten Trance inn zum Oga erwählen würde. sociedade que contribuem para a manutenção do templo.

Muitos transes "não previstos", que prometem para os próximos meses um bom rendimento.

Depois de gesticulações selvagens, as novas escolhidas dos deuses ficam deitadas rígidas no chão e são - como na África - enroladas em panos brancos e carregadas para as câmaras secretas da mãe.

Eu posso, de fora, ver lá dentro.

Repiques e defumadores devem trazer as petrificadas de volta a si.

De qualquer maneira, a Mãe tem full house.

A parente de uma recém-extática parece já ter sabido antes, pois ela trouxe logo todo o necessário para o tempo de iniciação.

Os dignitários brancos fazem o papel de organizadores de salão quando Leonore quer fotografar.

A Mãe se coloca sob protestos na luz propícia e endireita o pano sobre o peito.

Assim ela pode preservar a feição dos religiosos iorubás e ao mesmo tempo satisfazer sua vaidade.

\section{Página 36}

Como Leonore sabe disso, ela pode fotografar sem ofender alguém seriamente.

E quando ela vem pela segunda vez, perguntamIhe cheios de saudade, onde está a Kodak?!

Um dos ogãs de Viva Deus* é um jovem engenheiro.

Quando a Mãe quis designá-lo como dignitário, ela o informou que o deus o escolheria como ogã durante o próximo transe dela. 
- Jeder von uns bezahlt hier 50 Cruzeiros im Monat.

Von Rauschgift im Candomblé weiss P. nichts.

- Haschisch, Cannabis sativa, geht in die afrikanischen Rezepturen ein.

In Bahia stellen sich die Gläubigen immer sehr erstaunt, wenn ich innen eine Hanfplanze zeige. Vielleicht etwas zu erstaunt.

-Viele Mães de Santo werden "starke Persönlichkeiten « genannt, das heisst, sie sind Lesbierinnen. An der Sklavenküste wird lesbisches Verhalten nur versteckt angetroffen. Aber es gibt ein Yorubawort dafür:

- Der Preis für einen Sklaven war im Jahre 1857 etwa 10000 Dollar; dem entspräche heute das Doppelte.

P. glaubt nicht an den Fortschritt.

Er glaubt nicht, dass es den Menschen besser gehe, wenn sie im Überfluss leben.

- Diese Verschwendung. In Paris liegen die schönsten Pappkartons im Ascheimer. In Afrika stellt jede Pappkiste einen Wertgegenstand dar.

- Als Fotograf war ich fürchterlich. Ich hatte die reinsten Gangstermanieren. Ich habe Kindern Tritte versetzt, wenn sie in die Kamera guckten. Ich liebte mich nicht als Fotograf.

\section{Seite 37}

Kinoprogramm:

»Romeo und Julia « - mit Nurejev.

»Der Glöckner von Notre Dame.«

»Ḧllenengel.«

»Die Plünderer.«
- Cada um de nós paga aqui 50 cruzeiros por mês.

***

Sobre entorpecentes no Candomblé, P. não sabe nada.

- Haxixe, Cannabis sativa, entra nos receituários africanos.

$\mathrm{Na}$ Bahia, os fiéis se mostram sempre muito surpresos quando eu lhes mostro uma planta de cânhamo. Talvez um tanto surpresos demais.

- Muitas Mães de Santo são denominadas "personalidades fortes", isso significa, elas são lésbicas. $\mathrm{Na}$ costa dos escravos, 0 comportamento lésbico só é encontrado de forma acobertada. Mas há uma palavra iourubana para isso:

- O preço por um escravo era no ano de 1857 cerca de 10.000 dólares; ao qual corresponderia hoje o dobro.

P. não acredita no progresso.

Ele não crê que as pessoas estejam melhor quando elas vivem em abundância.

- Esse desperdício. Em Paris, os melhores papelões estão na lata de lixo. Na África, cada caixa de papelão representa um objeto de valor.

- Como fotógrafo, eu era horrível. Eu tinha os mais puros modos de gangster. Eu dava pontapés nas crianças quando elas olhavam na câmera. Eu não me amava como fotógrafo.

\section{Página 37}

Programa de cinema:

„Romeo e Julia“ - com Nurejev.

"O sineiro de Notre Dame."

"Anjo do inferno".

"Os saqueadores." 
"Das Geheimnis der Insel der Thugs."

"Das Gehirn.«

Die Wochenschau von Carlos Niemeyer.

- Kaffeeausfuhr ist durch das neue Regime ermöglicht worden.

- Neubauten in Rio de Janeiro.

- Pelé und andere Prominente beim Essen in Rio.

Fussball.

Hauptfilm im Cine Guarani:

"Korrupt und blutgierig."

Bei Professora Theresa sitzen nachmittags alle und sehen fern.

»Tarzan bei den Amazonen.«

Gegen sieben beginnt die Quitanda.

Opfer für Exu.

Tänze für die Götter.

Die neu eingeweihten Töchter bringen Tabletts herein voller Früchte, Kuchen, Bonbons.

Sie sind mit langen Ruten bewaffnet und setzen sich zum Verkauf hin. Zwei Würdenträgerinnen bewachen sie.

Die Gemeinde kauft.

Einige versuchen zu stehlen. Sie werden hart mit den Ruten geschlagen.

Nachdem ich etwas gekauft habe, versuche ich, zum Vergnügen aller, zu stehlen und kriege, zum Vergnügen aller, furchtbar einen rüber.

Es schmerzt so sehr, dass ich verstehe, wie man an Rutenschlägen zugrunde gehen kann.

Sklaven sind an Rutenschlägen gestorben.
"O segredo da ilha dos Thugs."

"O cérebro."

O jornal semanal de Carlos Niemeyer.

- Exportação de café é possibilitada pelo novo regime.

- Novos prédios no Rio de Janeiro.

- Pelé e outras celebridades em refeição no Rio.

Futebol.

Filme principal no Cine Guarani:

"Corrupto e ávido de sangue."

Na Professora Theresa todos estão sentados à tarde e veem televisão.

"Tarzan na terra das Amazonas."

Em torno das sete começa a Quitanda.

Sacrifício para Exu.

Danças para os deuses.

As filhas recém-iniciadas trazem para dentro bandejas cheias de frutas, bolo, balas.

Elas estão armadas com longas varas e sentamse para vender. Duas dignitárias vigiam-nas.

A comunidade compra.

Alguns tentam roubar. Eles são açoitados duramente com as varas.

Depois que eu comprei algo, eu tento, para a diversão de todos, roubar e, para a diversão de todos, levo uma terrível lambada.

Isso dói tanto, que eu entendo como se pode perecer por açoites de vara.

Escravos morreram por açoites de varas. 
Das Tanzen geht weiter.

Ein Caboclo, ein Indianergott, erscheint.

Der kleine Trommler, der die Pistole verkaufen wollte, wird in einem Stuhl herumgetragen.

Die Texte der Lieder sind portugiesisch.

Immer wieder das afrobrasilianische Sehnsuchtswort $\quad$ Luanda« - die Paradiesstadt.

\section{Seite 38}

Auch Professora Theresa fält in eine sehr zurückhaltende Trance.

- Das ist mein Fest, spricht sie als Caboclo.

Sie hat ein Geschenk mitgebracht. Eine Schüssel voll Blut.

Sie bietet allen davon an.

Es wird kultisch verweigert.

Sie bietet es den Würdenträgern noch einmal an und nun trinken die Auserwählten.

Wenn sie das Gesicht wieder aus der Schüssel heben, Lippen, Kinn blutig, verändert sich der Ausdruck ihrer Augen.

Der Indianische Waldgott bietet auch mir sein Geschenk an. Es schmeckt gut, säuerlich, wie Schwarzsauer, und nach Kräutern.

Ich habe vergessen, dass ich einen Bart habe und kleckere mein Zeug voller Blut.

\section{Carlos ist Bäcker.}

Er arbeitet von 11 Uhr abends bis sieben, acht Uhr morgens.

Er verdient 45 Cruzeiros in der Woche - etwas mehr als den Mindestlohn.

Er ist 25 und lebt mit einem Mädchen zusammen.
A dança continua.

Um Caboclo, um deus indígena, aparece.

O pequeno tocador de tambor, que queria vender a pistola, é carregado em uma cadeira por toda parte.

Os textos das canções são em português.

Outra e outra vez a palavra afrobrasileira de nostalgia, „Luanda“ - a cidade-paraíso.

\section{Página 38}

Também a professora Theresa cai em um transe

- Essa é minha festa, fala ela como caboclo.

Ela trouxe um presente. Uma tigela cheia de sangue.

Ela a oferece a todos.

Recusa-se ritualisticamente.

Ela a oferece mais uma vez aos dignitários e agora os escolhidos bebem.

Quando eles erguem novamente o rosto da tigela, lábios, queixo ensanguentados, a expressão dos seus olhos muda.

O deus indígena da floresta oferece também a mim seu presente. Tem gosto bom, acidulado, como sopa preta, e com sabor de ervas.

Eu me esqueci de que tenho uma barba e sujo a coisa toda de sangue.

***

Carlos é padeiro.

Ele trabalha de 11 horas da noite até sete, oito horas da manhã.

Ele ganha 45 cruzeiros por semana - um pouco mais que o salário mínimo.

Ele tem 25 anos e vive junto com uma moça. 
Er hat drei Kinder.

Bispo de Paris wird inn einweihen.

- Ich habe noch nicht alles von Candomblé gelernt.

- An wen glaubst du, Carlos: An Jemanha oder an die Jungfrau Maria?

- An beide.

- Aber das ist doch ein und dasselbe oder nicht?

- Das kann ich nicht sagen.

- Zu wem betest du: Zur Jungfrau Maria oder zu Jemanha?

- Zu beiden.

- Wenn man dich zwingen würde eines von beiden aufzugeben - den Candomblé oder die katholische Kirche.

- Dann würde ich den Candomblé aufgeben.

Er trommelt bei den Gottesdiensten. In einigen Tempeln aus Freundschaft - andre bezahlen dafür, drei Nächte bringen 40 Cruzeiros, also doppelt soviel wie das tägliche Brot.

\section{Seite 39}

P.:

-Die Homosexualität im Candomblé kommt von den Portugiesen. Die Afrikaner an der ehemaligen Sklavenküste sind daran nicht interessiert. Die jungen Männer tragen dort zur Einweihung die Haartracht der Mädchen, aber das ist nur, um auszudrücken, dass sie »Bräute« der Götter sind.

P. wird nach Afrika fahren, um dort mit einem französichen Fernsehteam einen Film über die Trance zu drehen.
Ele tem três filhos.

Bispo de Paris vai iniciá-lo.

- Eu ainda não aprendi tudo sobre o candomblé.

- Em quem você crê, Carlos: em lemanjá ou na Virgem Maria?

- Em ambas.

- Mas elas não são só uma e a mesma?

- Isso eu não sei dizer.

- Para quem você reza: para a Virgem Maria ou para lemanjá?

- Para ambas.

- Se te obrigassem a desistir de um dos dois - o candomblé ou a Igreja Católica.

- Então eu desistiria do candomblé.

Ele toca tambor nos serviços religiosos. Em alguns templos, por amizade - outros pagam por isso, três noites trazem 40 cruzeiros, portanto, o dobro do pão de cada dia.

\section{Página 39}

P.:

- A homossexualidade no candomblé vem dos portugueses. Os africanos na antiga costa dos escravos não eram interessados nisso. Os jovens homens usam lá na iniciação o cabelo penteado das moças, mas isso é só para expressar que eles são „noivas” dos deuses.

P. vai viajar para a África, para rodar lá, com uma equipe de televisão francesa, um filme sobre o transe. 
Die Einweihung der drei Töchter bei Professora Theresa ist nun fast abgeschlossen.

Das Haar der Geschorenen wächst wieder.

Sie helfen im Haushalt der Priesterin, um den Preis für die Einweihung abzuverdienen.

- Heute sollen die Kinder der Töchter gekauft werden!

- Was ist denn das?

Die Töchter bringen zwei Zelluloidpuppen, weisshäutige, blondlockige Zelluloidpuppen.

Die Waschmaschine wird als Altar hergerichtet, daneben ein Tisch mit Torten, Kuchen, Coca-Cola, künstlichen und echten Blumen.

Einer klebt noch schnell ein Pappkreuz an die Wand und der Heilige Antonius wird auf die Waschmaschine gestellt.

Der schwarze Mann, der an allen Zeremonien mit einer Sonnenbrille teilnimmt, verkleidet sich mit einem bunten Frauenrock in einen katholischen Priester; er ergreift einen Band der Volksenzyklopädie als Bibel.

Betimitation, Kirchengebimmel.

Zum Bibelzitat wird das Bild einer Giraffe aus der Volksenzyklopädie gezeigt.

Die Taufe der Puppen vollzieht der Priester über einem Aluminiumtopf.

Der falsche Priester imitiert die Wandlung.

Um ein Haar vergisst er die Taufe der zweiten Puppe.

Sie wird inn schnell gereicht.

Er legt Salz und das heilige Pulver Pemba auf den Zelluloidmund.

Einer sagt über die Puppen:
O cabelo das raspadas cresce novamente.

Elas ajudam na lida da casa da sacerdotisa, para abater no preço da iniciação.

- Hoje as crianças das filhas devem ser compradas!

- Mas o que é isso?

As filhas trazem duas bonecas de celulóide, de pele branca, bonecas de celulóide com cachos loiros.

A máquina de lavar é arranjada como altar, ao lado, uma mesa com tortas, bolo, Coca-Cola, flores artificiais e verdadeiras.

Um cola ainda rapidamente uma cruz de papelão na parede e o Santo Antônio é colocado em cima da máquina de lavar.

O homem negro que participa de todas as cerimônias com óculos de sol, fantasia-se com uma saia colorida de mulher em um sacerdote católico; ele agarra um volume da enciclopédia popular como Bíblia.

Imitação de oração, repique de sino de igreja.

Como citação da Bíblia mostra-se a figura de uma girafa da enciclopédia popular.

O batizado das bonecas, o sacerdote celebra sobre uma panela de alumínio.

O falso sacerdote imita a transformação.

Por um fio, ele esquece o batizado da segunda boneca.

Ela é entregue a ele rapidamente.

Ele coloca sal e o pó sagrado Pemba na boca de celulóide.

Um diz sobre as bonecas: 
- Die Brust ist aber schon reichlich entwickelt.

Als die Taufe vorüber ist, wundert sich der falsche Priester über die Trommeln und sagt drohend:

- Ihr veranstaltet hier doch wohl keine Candomblés?

\section{Seite 40}

- Nein! Nein!

- Was macht ihr den mit den Trommeln?

Die Spielleute zeigen es inm.

Sofort beginnt der Priester zu tanzen.

Die Mädchen gehen tanzend hinter dem tanzenden Transvestiten her, halten Röcke und Schürzen unter seinem Arsch auf, schaufeln mit den Schuhen hinter den Tänzern etwas auf.

Wie hinter einem Goldesel.

Dann stellen sich alle vor den Tisch mit den Süssigkeiten.

Langes afrikanisches Psalmodieren, bis die Torte angeschnitten wird.

Der Soziologieprofessor berichtet, dass P. früher mit seiner Fotografiererei Skandale ausgelöst habe.

Einige Priester warfen inn raus.

Bispo de Paris erlaubt, dass Carlos mir den Tempel zeigt.

- Der grosse Jaqueirabaum ist Omulu heilig. Nur Bispo de Paris darf von den Früchten essen.

- Die eingezäunten Bäume sind das Heiligtum des Caboclo Flecha Negra. Er verlangt Ochsenopfer. Die Schädel der geopferten Ochsen hängen in den Zweigen. Alle

- Mas o peito já está ricamente desenvolvido.

Quando o batizado termina, o falso sacerdote se espanta com os tambores e diz ameaçadoramente:

- Vocês não organizam aqui nenhum Candomblé, não é?

\section{Página 40}

- Não! Não!

- O que vocês fazem com os tambores?

Os tocadores do instrumento lhe mostram. Imediatamente o sacerdote começa a dançar.

As meninas vão dançando atrás do travesti dançante, seguram saias e aventais sob seu traseiro, escavam algo com os sapatos atrás dos dançarinos

Como atrás de um burro de ouro.

Então elas se colocam todas diante da mesa com os doces.

Longo salmodiar africano, até que a torta é cortada.

***

O Professor de Sociologia relata que P. antigamente provocava escândalos com sua fotografança.

Alguns sacerdotes jogaram-no para fora.

***

Bispo de Paris permite que Carlos me mostre o templo.

- A grande árvore de jacas é sagrada de Omulu. Só Bispo de Paris pode comer das frutas.

- As árvores cercadas são o santuário do Caboclo Flecha Negra. Ele exige sacrifício de boi. Os crânios dos bois sacrificados estão pendurados nos galhos. Todos os objetos do 
Gegenstände des Altars werden in dem Blut der Opfertiere gebadet.

Für die Indianer werden keine Menschen mit Blut gebadet.

Bispo de Paris hat Heiligenhäuschen für Exu, für Ogum, für Omulu und für die Eguns, die Toten.

Betreten dürfen wir keines.

An dem Haus der Toten hängt ein weisses Kleid. Es ist eine Dankesgabe, weil sie Bispo de Paris eine »Arbeit« gelingen liessen.

Am nächsten Freitag will Professora Theresa mit den drei neuen Töchtern in die Kirchen der katholischen Heiligen gehen, die den afrikanischen Göttern der Neophyten entsprechen.

Ihr ist es nicht angenehm, dass wir sie begleiten wollen, aber als wir uns zurückziehen, ist es ihr auch nicht recht.

\section{Seite 41}

Die Mutter des kleinen Omulu fängt an zu weinen, weil sie das Geld für die Einweihung nicht aufbringen kann - Professora Theresa fällt auch prompt in Trance, wirft ihre Brille weg und erklärt im Kultton des Gottes, die Töchter hätten ihrer Mutter zu gehorchen. Sie würden ihre Mãe noch brauchen. Xango, sie selbst also, der Gott des Feuers und des Blitzes, würde schon dafür sorgen, dass sie das Geld zusammenbrächte.

Das kostet Professora Theresa in ihrem unzurechnungsfähigen Zustand nicht viel.

Dann geht es in zwei Taxen los. Zuerst nach Bonfim, zu Herrn Jesus Christus. Aber sie dürfen nicht eintreten und umkreisen im Taxi die Kirche. Dann für Oxum zu Nossa Senhora altar são banhados no sangue dos animais de sacrifício.

Para os índios, nenhuma pessoa é banhada com sangue.

Bispo de Paris tem casinhas sagradas para Exu, para Ogum, para Omulu e para os Eguns, os Mortos.

Entrar, não podemos em nenhuma.

Na casa dos Mortos está pendurado um vestido branco. É uma oferenda de agradecimento, porque eles deixaram um „trabalho" de Bispo de Paris dar certo.

$* * *$

Na próxima sexta-feira Professora Theresa quer ir com as três novas filhas às igrejas dos santos católicos que correspondem aos deuses africanos das neófitas.

Ela não acha agradável que nós queiramos acompanhá-la, mas quando nós recuamos, ela também não está de acordo com isso.

\section{Página 41}

A mãe do pequeno Omulu começa a chorar, porque ela não consegue arranjar o dinheiro para a iniciação - Professora Theresa cai de pronto em transe, atira fora seus óculos e explicou no tom ritualístico do deus, as filhas teriam que obedecer sua mãe. Elas ainda iriam precisar de sua Mãe. Xangô, ela mesma, portanto, o deus do fogo e do raio, iria cuidar para que ela conseguisse juntar o dinheiro.

Isso não custa muito à Professora Theresa, em seu estado de inaptidão mental.

Então, saídas em dois táxis. Primeiro para Bonfim, para o Senhor Jesus Cristo. Mas elas não podem entrar e circundam de táxi a igreja. Então, para Oxum, à Nossa Senhora da 
da Conceção, zu Unserer lieben Frau von der Unbefleckten Empfängnis. Für Oxossi zum Heiligen Antonius - lässt sich unter den angeblich 365 Kirchen in Bahia keine finden, die dem Heiligen Sebastian geweiht ist? - Es gibt einen Oxossi, für den die Novizen mit Federn gespickt werden wie der Heilige Sebastian mit Pfeilen. An der Kirche des Heiligen Antonius steigen die Mädchen aus dem Taxi und beten vor der Tür.

Nun wird das Kapellchen des Heiligen Lazarus gesucht. Nach einigem Fragen finden wir es.

Abgelegen.

Wohl an einer ehemaligen Leprastation errichtet.

Hier hat der Pfarrer die Erlaubnis erteilt, dass die Gläubigen des Candomblé eintreten dürfen, wohl auch, um die Pilger des hier jährlich stattfindenden Omulufestes nich zu verärgern. Das bringt der Kirche einiges.

Morgen findet an der weissandigen Lagune von Abaete eine Konfirmation der drei Töchter mit der Jungfrau Maria statt.

Wir sind da und warten vergebens.

Ich mache mir eine Liste der wichtigen Candomblés in Bahia de Todos os Santos.

$P$. empfiehlt mir die drei alten, klassischen Yorubatempel:

Casa Branco, ehemals Engenho Velho, in der Vasco da Gama 436. São Jorge de Gantois, auch Meneninha de Gantois, Alto do Gantois 33, Senhora, Apo Afonja, São Gonzalo do Retiro.

Jorge Amado erwähnt:

\section{Seite 42}

Sociedade São Jeronimo lle Moroialaje, den Tempel von Olga de Alaketu, Matatu de Brotas, Rua Luis Anselmo 65.
Conceição, à Nossa Querida Senhora da Imaculada Conceição. Para Oxossi, ao Santo Antônio - não se pode encontrar em nenhuma das supostas 365 igrejas da Bahia uma que seja consagrada ao São Sebastião? - Há um Oxossi, para o qual as noviças são salpicadas de penas como o São Sebastião com flechas. Na igreja do Santo Antônio, as meninas desembarcam do taxi e rezam diante da porta.

Agora procura-se a capelinha do São Lázaro. Depois de algumas perguntas, nós a achamos.

Afastada.

Provavelmente erguida em uma antiga estação de cura de lepra.

Aqui o padre concedeu a permissão, para que os fiéis do Candomblé pudessem entrar, mas também para não aborrecer os peregrinos da festa de Omulu, que aqui ocorre anualmente. Isso traz algo à igreja.

Amanhã acontece na Lagoa do Abaeté, de areias brancas, uma confirmação das três filhas com a Virgem Maria.

Nós estamos lá e esperamos em vão.

Eu faço uma lista dos mais importantes candomblés na Bahia de Todos os Santos.

P. me recomenda os três antigos, clássicos templos iorubás:

Casa Branco*, antigo Engenho Velho*, na Vasco da Gama 436. São Jorge de Gantois*, também Menininha de Gantois, Alto do Gantois 33, Senhora, Apo Afonjá, São Gonzalo do Retiro.

Jorge Amado cita:

\section{Página 42}

Sociedade São Jerônimo llê Moroialaje, o templo de Olga de Alaketu, Matatu de Brotas, Rua Luis Anselmo 65. 
Casa de Oxumare, Vasco da Gama 343.

Emiliana do Bogum, das einzige Haus mit einem reinen Ewekult.

Casa do Babalorixa Eduardo Ixexa, im Jardim Madalena.

Bernardinho do Bate Folha.

Marieta, Fazenda Grande do Retiro.

Auf der Insel Itapacarica in der Bucht die Kulte der Toten.

\section{Ein Schneider:}

- Ich wurde 1933 im Bundesstaat Sergipe geboren.

- Mein Vater war Friseur, meine Mutter Näherin.

- Ich habe zehn Geschwister.

Unsere Familie lebte in einem eigenen Haus, so einem einfachen Haus mit Zimmern, die oben offen sind, damit die Luft unter dem Dach ventilieren kann.

- Mein Vater kümmerte sich wenig um die Kindererziehung. Die Mutter war wichtig.

- Wir wurden oft geschlagen. Unsre Mutter schlug. Mit dem Lineal auf die Hände. Oder mit Lederriemen. Oder mit der Faust auf den Kopf.

- Ich besuchte das Gymnasium. Auch die Lehrer schlugen uns.

Am Sonnabend wurden uns die Lektionen abgefragt. Die besseren Schüler durften die dummen verprügeln.

- Die Sauberkeit ist bei uns fast ein Komplex. Vielleicht durch das tropische Klima bedingt und durch unsere indianische und afrikanische Abstammung.
Casa de Oxumaré, Vasco da Gama 343.

Emiliana do Bogum, a única casa com um puro culto ewe.

Casa do Babalorixá Eduardo ljexá, no Jardim Madalena.

Bernardinho do Bate Folha*.

Marieta, Fazenda Grande do Retiro.

Na llha de Itapacarica, na baía, os cultos dos mortos.

***

Um alfaiate:

- Eu nasci em 1933 no Estado de Sergipe.

- Meu pai era cabeleireiro, minha mãe costureira.

- Eu tenho dez irmãos.

Nossa família vivia em uma casa própria, numa casa bem simples com cômodos que são abertos em cima, para que o ar abaixo do teto possa circular.

- Meu pai cuidou pouco da educação das crianças. A mãe foi importante.

- Nós levavamos frequentemente uma surra. Nossa mãe batia. Com a régua nas mãos. Ou com correias de couro. Ou com o punho na cabeça.

- Eu frequentei o ginásio. Também os professores nos batiam.

No sábado nos tomavam as lições. Os melhores alunos podiam espancar os burros.

- A limpeza é na nossa casa quase um complexo.

Talvez condicionado pelo clima tropical e pela nossa origem indígena e Africana. 
- Jeder in der Familie nahm morgens und nachmittags ein Bad.

Wir hatten natürlich kein fliessendes Wasser. Die Kinder mussten das Badewasser in Kanistern auf dem Kopf herbeischaffen.

- Es hiess immer: Neger und Mulatten riechen nicht gut.

- Früher war die Ernährung in Brasilien besser. Sogar eine arme Familie wie die unsere mit zehn Kindern kam einigermassen durch.

- Neue Hemden und Kleider gab es immer zu den Festen.

- Solange ich denken kann, interessiere ich mich für Musik, Malerei und Holzschnitzerei.

- Nähen durfte ich als Junge nicht. Das war verpönt. Ehe ich in der Modebranche zu arbeiten anfing, war ich Fotograf.

\section{Seite 43}

- Seit ich elf bin, habe ich sexuelle Interessen.

- In der Familie wurde über Sex nie gesprochen. Keines der Kinder wagte, die Eltern beim Sex zu beobachten. Wir hätten uns zu sehr geschämt, über die Dinge, die wird gehört hatten, zu reden.

- Wir Kinder spielten Vater und Mutter.

- Sexuelle Kontakte unter Jungen allein waren schwierig. Wir masturbierten voreinander und massen unsere Schwänze. Das war alles.

- Ich habe, seit ich sechzehn bin, Beziehungen zu Männern. Ich bin der aktive. Das gilt hier im allgemeinen nicht als Homosexualität. Nur der Passive ist homosexuell. Aber ich weiss, dass es bei mir keine Ersatzhandlung oder eine Variante meines Sexualverhaltens ist. Ich weiss, dass ich nur Männer will und also homosexuell bin.
- Cada um na família tomava de manhã e à tarde um banho.

Nós não tínhamos naturalmente nenhuma água corrente. As crianças tinham que transportar a água de banho em latas na cabeça.

- Sempre se disse: pretos e mulatos não cheiram bem.

- Antigamente a alimentação no Brasil era melhor. Até uma família pobre como a nossa com dez filhos sobrevivia razoavelmente.

- Novas camisas e vestidos sempre havia para as festas.

- Desde que me entendo por gente, eu me interesso por música, pintura e escultura em madeira.

- Costurar eu não podia, como menino. Isso era mal visto. Antes de começar a trabalhar no ramo da moda, eu era fotógrafo.

\section{Página 43}

- Desde que tenho onze anos, eu tenho interesse sexuais.

- Na família nunca se falava sobre sexo. Nenhuma das crianças ousava observar os pais durante o sexo. Nós teríamos nos envergonhado de falar das coisas que tivéssemos ouvido.

- Nós, crianças, brincávamos de papai e mamãe.

- Contatos sexuais só entre os meninos eram difíceis. Nós nos masturbávamos diante dos outros e medíamos nossos pênis. Isso era tudo.

- Eu, desde que tinha dezesseis anos, tinha relacionamentos com homens. Eu sou o ativo. Isso aqui não é considerado, em geral, como homossexualidade. Só o passivo é homosssexual. Mas eu sei que para mim isso não é um comportamento substitutivo ou uma variante do meu comportamento sexual. Eu sei, que eu só quero homens e sou, então, homossexual. 
- Ich wagte nur, auf Reisen was zu machen. Homosexualität war damals in einem kleinen Städtchen noch unmöglich. Nur Homosexuelle, die sich sehr diskret verhielten, konnten in einer Kleinstadtgesellschaft bestehen. Sie wurden mehr oder weniger geduldet. Einfachere Leute bauten ihre Vorurteile gelegentlich unter Alkohol ab. Dann gaben sich sogar virile, verheiratete Landarbeiter als Frauen hin. Aber das ist wohl auf der ganzen Welt so -

In der Bundesrepublik Deutschland nicht?

- Erst in Rio überwand ich die Scheu und nahm sogar an Sexparties teil. Das war damals Mode, heute ist es wohl schon wieder ein bisschen passé.

- Mit 22 kam ich als Fotograf nach Bahia.

- Das Gay-Life ist hier nicht allzu schwierig. Es gibt keine Parks wie in Rio. Auf die Klappen gehe ich nicht. Am Busbahnhof oder an der Eisenbahn spielt sich ein bisschen was ab. Hauptsächlich aber in einigen Kinos. Ich kann es mir natürlich nicht erlauben, mich da sehen zu lassen. Unter dem vorigen Gouverneur war alles ziemlich tolerant. Aber der neue hat versprochen aufzuräumen und das fängt ja bekanntlich immer mit Razzien auf Homosexuelle an.

Viele nehmen sich auch ein Zimmer in einem der kleinen Hotels und knüpfen ihre Kontakte dann über den Gang an.

- Es gibt viele Bars. Nicht gerade Gay-Clubs. Aber so gemischt.

Jeden Tag werden welche zugemacht und jeden Tag machen neue auf.

- Mode hat mich im Grunde schon immer interessiert. Die Leute

\section{Seite 44}

sagten auch zu mir: Du bist gut angezogen. Ich bin völliger Autodidakt, was das Schneidern
- Eu só me atrevia a fazer algo em viagens. Homosexualidade era naquela época em uma pequena cidade ainda impossível. Só homossexuais que se comportavam muito discretamente podiam continuar existindo numa sociedade de pequena cidade. Eles eram mais ou menos tolerados. Pessoas mais simples desmontavam seus preconceitos às vezes sob o álcool. Então até homens viris, trabalhadores rurais casados, entregavam-se como mulheres. Mas isso é assim no mundo inteiro -

$\mathrm{Na}$ República Federal da Alemanha deve ser também, não?

- Só no Rio eu superei a timidez e até tomei parte em festas sexuais. Isso era moda naquela época, hoje isso já é de novo um pouco demodé.

- Com 22 eu vim como fotógrafo para a Bahia.

- A vida gay aqui não é difícil demais. Não há parques como no Rio. Aos banheiros públicos eu não vou. Na estação de ônibus ou na estação de trem acontece alguma coisa. Mas principalmente em alguns cinemas. $\mathrm{Eu}$, naturalmente, não posso me permitir ser visto lá. Sob o governador anterior tudo era bem tolerante. Mas o novo prometeu fazer uma limpeza e isso sempre começa, sabidamente, com razias policiais contra homossexuais.

Muitos pegam um quarto em um dos hoteizinhos e travam seus contatos então no corredor.

- Há muitos bares. Não exatemente clubes gays. Mas, assim, mistos.

Todos os dias alguns são fechados, e todos os dias abrem novos.

- Moda, no fundo, sempre me interessou. As pessoas também

\section{Página 44}

me diziam: você está bem vestido. Eu sou completamente autodidata, no que diz respeito à 
angeht. Mit 24 fing ich an, Hemden zu schneidern. Ein bisschen schickere als die aus den Buden der Hemdenschneiderinnen in den Favelas. Aber die bekommen ja auch ein paar Cruzeiros pro Hemd und müssen wenigstens zehn am Tag fix und fertig nähen, sonst verhungern sie.

- Später machte ich dann auch Hosen und Jacken.

- Bei mir kaufen Leute aus allen Schichten. Arbeiter mit Salario Minimo auf Stottern; sie brauchen sonnabends eine neue, modische Hose, sonst haben sie bei den Mädchen keine Chancen. Bei mir kaufen auch Leute der High Society.

- Meine Kunden verdienen so zwischen 400 und 1.000 Cruzeiros im Monat.

- Mein Einkommen liegt bei 1.500 Cruzeiros monatlich - um die 1.000 Mark.

- Ich bezahle den einfachen Angestellten, was das Gesetz von mir verlangt - 146 Cruzeiros. Die besseren verdienen bis zu 440 Cruzeiros.

- Die Kinder fangen hier gewöhnlich mit elf an zu arbeiten. Sie verdienen dann die Hälfte eines Salario Minimo - also 73 Cruzeiros - 50 Mark - im Monat.

- In Brasilien hat sich noch keine selbständige Mode entwickeln können. Die Reichen, die etwas auf sich halten, fliegen zweimal im Jahr nach Europa, um sich einzukleiden. Andre, die sich das nicht leisten können, lassen sich die Schilder der berühmten europäischen Modehäuser in brasilianische Kleider nähen, die nach europäischen Vorbildern genäht werden.

- Die Couturiers, die ich am meisten bewundre, sind Yves Saint-Laurent, Pierre Cardin und Mary Quant. alfaiataria. Com 24 eu comecei a cortar camisas. Um pouco mais chique que aquelas dos barracos das costureiras de camisas nas Favelas. Mas elas recebem também uns poucos Cruzeiros por camisa e têm que, pelo menos, costurar dez por dia exaustivamente, senão elas morrem de fome.

- Mais tarde eu fiz então calças e casacos.

- Comigo compram pessoas de todas as classes.

Trabalhadores com Salario Minimo à prestação; eles precisam aos sábados de uma nova calça, na moda, senão não têm nenhuma chance com as meninas. Comigo compram também pessoas da High Society.

- Meus clientes ganham assim entre 400 e 1.000 Cruzeiros por mês.

- Minha renda fica em torno dos 1.500 Cruzeiros mensais - cerca de 1.000 Marcos.

- Eu pago aos funcionários simples o que a lei exige de mim - 146 cruzeiros. Os melhores ganham até 440 cruzeiros.

- As crianças começam aqui normalmente a trabalhar com onze anos. Elas ganham então a metade do Salario Minimo - ou seja 73 cruzeiros - 50 marcos - por mês.

- No Brasil ainda não se desenvolveu uma moda autônoma. Os ricos que se prezam voam duas vezes por ano para a Europa para se vestirem. Outros, que não podem se dar ao luxo, mandam costurar as etiquetas das famosas casas de moda europeias nas roupas brasileiras que são costuradas segundos os modelos europeus.

- Os costureiros que eu mais admiro são Yves Saint-Laurent, Pierre Cardin e Mary Quant. 
- Mein Stil ist etwa mit dem von Jean Bouquin zu vergleichen.

Aber ich halte das für eine sehr gefährliche Mode.

- Ich bin gegen die Todesstrafe. Eine Regierung sollte paternalistisch sein. Ich stelle mir die Regierung in Holland so vor.

- Folter hat es immer gegeben.

- Ich finde die Regierung in Kuba entsetzlich.

- Ich lese nicht viel und interessiere mich im Grunde nicht für Politik. Ich interessiere mich hauptsächlich für Musik, Tanz und Volkskunst.

- Ich bin Katholik, aber ich besuche auch den Candomblé. Jeder

\section{Seite 45}

in Bahia glaubt an den Candomblé. In ganz Brasilien glauben sicher 60 Millionen daran.

- Ich werde demnächst nach Europa gehen. Es gibt hier keine guten Arbeitsbedingungen. Es werden keine Mittel bereitgestellt, um eine spezifisch brasilianische Mode zu entwickeln. Es werden keine neuen Textilfasern erforscht. Es gibt keine Modefachschulen. Im Prêt-àPorter sieht man immer Kopien ausländischer Modelle.

- Die Zeitschriften des Burdakonzerns üben einen ungeheuren Einfluss auf die Mode des brasilianischen Volkes aus. Sie haben sicher gesehen, dass in allen Familien dauernd genäht wird - auch in den Favelas. Alle diese Kleider werden nach Burdaschnitten angefertigt.'Burda-Moden" kann man an jedem Kiosk kaufen. Das ist eine grossartige Entwicklungshilfe.

Uns gegenüber wohnt ein Baumaterialienhändler. Er ist verheiratet und hat zwei kleine Jungen. Er gehört - mit einer
- Meu estilo é mais ou menos comparável ao de Jean Bouquin.

Mas eu a considero uma moda muito perigosa.

- Eu sou contra a pena de morte. Um governo deveria ser paternalista. Eu imagino o governo da Holanda assim.

- Tortura sempre houve.

- Eu acho o governo em Cuba terrível.

- Eu não leio muito e não me interesso no fundo por política. Eu me interesso principalmente por música, dança e arte popular.

- Eu sou católico, mas respeito também o Candomblé. Todos

\section{Página 45}

na Bahia acreditam no candomblé. Em todo o Brasil certamente acreditam 60 milhões nele.

- Eu irei em breve à Europa. Não há aqui boas condições de trabalho. Não são disponibilizados meios para desenvolver uma moda brasileira específica. Não são pesquisadas novas fibras têxteis. Não há escolas especialistas em moda. No Prêt-à-Porter veem-se sempre cópias de modelos estrangeiros.

- As revistas do grupo Burda exercem uma enorme influência na moda do povo brasileiro. $\mathrm{O}$ Senhor certamente viu que em todas as famílias permanentemente se costura - também nas Favelas*. Todas essas roupas são feitas segundo os cortes da Burda. "Burda-Modas" pode-se comprar em toda banca. Isso é uma ajuda formidável ao desenvolvimento.

À nossa frente mora um comerciante de material de construção. Ele é casado e tem dois meninos pequenos. Ele pertence - com uma mansão na praia - aos ricos de Salvador. 
Villa am Stadtrand - zu den Reichen von Salvador.

Weil wir Deutsche sind, hat er uns auf der Rechnung - obwohl wir in einem halbfertigen Haus wohnen, keinen Wagen haben, keinen Hausdiener und mit dem Bus fahren.

- Die Deutschen sind das klügste Volk der Welt, sagt er, um uns eine Freude zu machen.

- In zehn Jahren ist Brasilien so weit wie Deutschland.

Der Baumaterialienhändler fährt morgens um sieben in sein Büro.

Um eins kommt er zum Essen nach Hause.

Gegen sieben abends kommt er von der Arbeit zurück.

Gelegentlich wird es später; dann macht inm seine Frau eine Szene und er antwortet:

- Das ist absurd.

Der Baumaterialienhändler ist etwas unordentlich eingerichtet, aber er besitzt einen grossen Marmortisch für Bankette und goldene Wasserhähne in den zwei Badezimmern.

Er beschäftigt einen Chauffeur. Er beschäftigt einen Mann für alles, der auch im Garten arbeiten muss und mit weissen Handschuhen den Balanceakt mit dem Kaffeetablett vollführen. Der Baumaterialienhändler beschäftigt ein Kindermädchen, eine Köchin, ein Mädchen für die Wäsche.

\section{Seite 46}

Die Frauen erhalten einen Lohn von etwa 50 Mark im Monat und haben sich zwölf Stunden bereitzuhalten.

Sicherlich arbeiten sie sich nicht tot, im deutschen Sinne - doch sind die Temperaturen und die Luftfeuchtigkeit hier auch nicht mitteleuropäisch.
Porque nós somos alemães, ele nos tem em grande conta - embora nós moremos em uma casa semipronta, não tenhamos carro, nem criados domésticos e andemos de ônibus.

- Os alemães são o povo mais inteligente do mundo, diz ele, para nos fazer um agrado.

- Em dez anos, o Brasil estará tão adiantado quanto a Alemanha.

O comerciante de material de construção vai de carro pela manhã às sete para seu escritório.

À uma ele vem para comer em casa.

Por volta das sete ele chega de volta do trabalho.

Por vezes fica mais tarde, então sua mulher faz um escândalo e ele responde:

- Isso é absurdo.

O comerciante de material de construção tem acomodações um pouco desarrumadas, mas ele possui uma grande mesa de mármore para banquetes e torneiras douradas nos dois banheiros.

Ele emprega um chofer. Ele emprega um homem faz-tudo, que também tem que trabalhar no jardim e, com luvas brancas, realizar o ato de equilíbrio com a bandeja de café. O comerciante de material de construção emprega uma babá, uma cozinheira, uma moça para as roupas.

\section{Página 46}

As mulheres recebem um salário de cerca de 50 marcos por mês e têm que estar disponíveis por 12 horas.

Certamente não se matam de trabalhar, no sentido alemão - mas as temperaturas e a umidade do ar aqui não são as da Europa Central. 
Der Baumaterialienhändler zieht immerhin zweimal am Tag ein frisches Hemd an. Handgebügelt.

Die Unterwäsche der ganzen Familie wird selbstverständlich täglich gewechselt, ebenso die Servietten, die Handtücher, Tischtücher. Der Baumaterialienhändler bezahlt für seine Angestellten keine Sozialabgaben - er übernimmt die sehr lockere moralische Verpflichtungen, den Angestellten Medikamente zu kaufen und gelegentlich ein Hemd oder ein Kleid.

Er gibt sicherlich nicht mehr als 50 Mark für die Ernährung eines jeden Dienstboten im Monat aus, denn sie essen bei inm nicht besser, als sie arbeitslos in ihrer Elendshütte essen würden. Ich glaube nicht, dass der Baumaterialienhändler mehr als 1.500 Mark für den Unterhalt seiner Familie im Monat aufwendet.

500 Mark kosten inm alles in allem alle seine Angestellten. 500 Mark die Amortisation seines Hauses. Ein paar hundert Mark der amerikanische Wagen - Galaxie, Ford.

Mit einem Nettoverdienst von höchstens 3.000 Mark kann er also - auf Grund der sklavenartig gehaltenen Angestellten - das Leben eines mittleren Paschas führen.

Seine Frau verbringt ihre Tage damit, unter Lockenwicklern zu klönen und zu keifen; sie rührt nichts an und ist abends völlig erschöpft, denn was auf der Welt strengte mehr an, als zu klönen und zu keifen?

Als Ehefrau wird sie gelegentlich noch mal eine halbe Nacht beschäftigt sein.

Abends Fernsehen.

Sonnabends ist Hallo!

Unbedingt sollen wir rüberkommen!

- Muscheln essen!

- Das macht potent.
O comerciante de material de construção veste pelo menos duas vezes por dia uma camisa limpa. Passada a mão.

A roupa íntima da família inteira é trocada, é claro, diariamente, assim como os guardanapos, as toalhas de mão, toalhas de mesa. O comerciante de material de construção não paga aos seus empregados nenhuma contribuição social - ele assume as obrigações morais bem leves de comprar medicamento para os empregados e, por vezes, uma camisa ou um vestido.

Ele gasta, com certeza, não mais que 50 marcos por mês com a alimentação de cada empregado doméstico, pois em sua casa eles não comem melhor que comeriam, desempregados, em seus barracos miseráveis. Eu não creio que o comerciante de material de construção gaste mais que 1.500 marcos com o sustento de sua família por mês.

500 marcos custam a ele ao todo seus empregados. 500 marcos a amortização de sua casa. Algumas centenas de marcos, o carro Americano - Galaxie, Ford.

Com um rendimento líquido de no máximo 3.000 marcos, ele pode, então - devido aos seus empregados escravizados - levar a vida de um paxá médio.

Sua mulher passa seus dias de bobes a bater papo e a berrar; ela não toca em nada e à noite está completamente exausta, pois o que cansa mais no mundo que bater papo e berrar?

Como esposa, ela estará eventualmente ocupada de novo uma meia noite.

À noite, televisão.

Sábado é dia de dizer um oi!

De qualquer maneira temos que ir até lá!

- Comer ostras!

- Isso dá potência. 
- Ich bin für Anarchie, ruft die Frau des Baumaterialienhändlers.

- Es lebe Deutschland!

- Wir Brasilianer haben ein gutes Herz. Weinen Sie, wenn die Grossmutter Ihres Dienstmädchens stirbt?!

\section{Seite 47}

Ich gelte als herzlos, als ich erkläre, dass ich in Deutschland kein Dienstmädchen beschäftige und dass ich keinen Grund sehen, warum er beim Tod seines Dienstmädchens weinen müsste.

Batida sollen wir in uns hineinkippen.

Dann werden die zehn anwesenden Männer von ihren Frauen, Müttern, Schwestern, Ammen in den Essaal gestossen. Fleisch, Bohnen, Reis, Mehl, Bier, Schnaps, CocaCola, Bananen, Kaffee im Laufschritt aufgetragen, auf die Teller und in Kristalgläser gefüllt, unter Gähnen und Rülpsen verschlungen.

Die Frauen stehen dabei, kichern, stopfen den Männern Brocken in den Mund, hapsen sich selbst was weg. In einer Viertelstunde ist alles verputzt. Man legt sich zum Nachmittagsschlaf.

Pelé zeigt uns den Trakt, der für die Hausangestellten gebaut wird: Fünf vier Quadratmeter grosse Kojen, ohne Fenster, mit einem Luftschlitz über der Tür.

Bis zur Fertigstellung schläft Pelé weiter in der Garage.

\section{Ein Soziologe:}

- Von 1.960 Bewohnern des bahianischen Stadtteils Maciel arbeiten 690 Jugendliche nicht.
- Eu sou pela anarquia, grita a mulher do comerciante de material de construção.

- Viva a Alemanha!

- Nós brasileiros temos um bom coração. $O$ Senhor chora quando a avó de sua empregada morre?!

\section{Página 47}

Eu sou considerado sem coração quando eu explico que eu, na Alemanha, não emprego nenhuma doméstica e que eu não vejo motivo, por que ele deveria chorar na morte de sua doméstica.

Batida nós devemos entornar para dentro.

Então os dez homens presentes são empurrados por suas mulheres, mães, irmãs, amas para a sala de jantar. Carne, feijão, arroz, farinha, cerveja, cachaça, Coca-Cola, bananas, café são trazidos a passos acelerados, servidos nos pratos e nos copos de cristal, engolidos sob bocejos e arrotos.

As mulheres ficam junto, dão risadinhas, entopem os homens com nacos na boca, fisgam algo para si. Em um quarto de hora, foi feito uma limpa. Deitam-se para tirar uma soneca da tarde.

Pelé nos mostra o barracão que está sendo construído para os empregados domésticos: cinco cabines de quatro metros quadrados, sem janela, com uma grelha de ventilação acima da porta.

Até a finalização, Pelé continua dormindo na garagem.

Um sociólogo:

- De 1.960 moradores do bairro bahiano Maciel, 690 jovens não trabalham. 
- Es gibt 449 Prostituierte, davon sind 24 minderjährig. Die Kinder fangen hier mit zwölf Jahren an.

- Viele Häuser, die als Bordelle und Absteigen dienen, gehören religiösen Bruderschaften, das heisst, sie werden von der Kirche vermietet.

- Es stimmt, auf 80 Bewohner kommt nur eine Toilette.

- Die Einwohner behaupten: Auf jeden Menschen kommen hier zehn Ratten. Die Seuchengefahr ist beträchtlich. Besonders die unheilbare Leptospirose wird gefürchtet.

- Lepra gibt es hier nicht - aber in den anderen Vierteln der Stadt. Ein Leprakranker verkaufte jahrelang Süssigkeiten im Viertel Liberdade. Neben dem Hospital da Misericordia im Stadtteil Montserrat gibt es noch heute eine Leprastation.

- Wir leben in Brasilien in einer Informationsleere, die schmerzt.

Man hat noch die Freiheit zu reden, was man will. Aber die Universitätsprofessoren müssen bereits einen Revers unterschreiben, dass sie keine Meinungen vertreten wollen, die der Politik des Staates entgegengesetzt sind.

Ich will nicht reden können, ich will handeln können.

\section{Seite 48}

- Jeder von uns hat daran gedacht zu emigrieren. Ich bin zu der Auffassung gekommen, dass ich hier versuchen muss, das Mögliche zu tun.

- Ich habe mich vom Staat anstellen lassen und verdiene 220 Cruzeiros im Monat - etwas mehr als 140 Mark. Aber seit drei Monaten ist uns kein Gehalt ausbezahlt worden.

Ein Professor aus Ghana:
- Há 449 prostitutas, 24 dentre elas são menores de idade. As crianças começam aqui com doze anos.

- Muitas casas que servem como bordéis e hoteizinhos baratos pertencem a irmandades religiosas, isto significa, elas são alugadas pela igreja.

- É verdade, para cada 80 moradores só tem um toalete.

- Os habitantes afirmam: para cada pessoa há aqui dez ratazanas. O perigo de contaminação é considerável. Principalmente a leptospirose incurável é temida.

- Lepra não há aqui - mas nos outros bairros da cidade. Um doente de lepra vendeu durante anos doces no Bairro Liberdade. Ao lado do Hospital da Misericordia no Bairro Montserrat há ainda hoje uma estação de cura de lepra.

- Nós vivemos no Brasil em um vazio de informação que dói.

Ainda se tem a liberdade de falar o que se quer. Mas os professores universitários têm já que assinar uma declaração de compromisso, que eles não querem representar nenhuma opinião, que seja contrária à política do estado.

Eu não quero poder falar, eu quero poder agir.

\section{Página 48}

- Cada um de nós pensou em emigrar.

Eu cheguei à conclusão, que eu devo tentar fazer o possível aqui.

- Eu me empreguei no estado e ganho 220 cruzeiros por mês - um pouco mais que 140 marcos. Mas há três meses não nos pagam nenhum salário.

Um professor universitário de Ghana: 
- Ich versuche den Schwarzen hier klarzumachen, dass es sehr wohl einen brasilianischen Rassismus gibt.

- Man schätzt den Anteil der Schwarzen in Brasilien auf 75 bis 85 Prozent. In Bahia gibt es weniger als 1 Prozent reine Weisse. Jedoch: Kein Professor ist Neger, es gibt nur einen katholischen Negerpriester und zwölf schwarze Ärzte. Noch heute werden Neger in den Luxushotels der Stadt scharf angesehen oder man erteilt innen die Auskunft: Wir sind besetzt.

In den besseren Schulen der Stadt gibt es keine Plätze für schwarze Kinder.

- Übrigens gibt es einen schwarzen Architekten in der Stadt.

- Bahia hat fünf elegante Clubs: Den Portugues, den Esporte, den Athletico, den Jachtclub und den Tennisclub. In keinen wird ein Neger aufgenommen, es sei denn als Fensterputzer oder Küchenjunge.

In den Banken von Bahia sehen keinen schwarzen Angestellten - höchstens die Telefonistin - und die ist für das Publikum nicht sichtbar.

In Annoncen werden Angestellte mit "angenehmem" Äusseren gesucht.

- Es gibt in Brasilien noch heute Kartoons, die ein Bild des Schwarzen propagieren, wie es in den USA während der zwanziger Jahre verbreitet wurde:

Der Neger mit grossen rollenden Augen.

- Am 6. Januar 1970 veröffentlichte die Illustrierte „Manchete" einen Witz, in dem eine Weisse einen „Gorilla“ aus Ghana heiratet.

-Zwar können sich in Brasilien Schwarze und Weisse heiraten, aber von der Gesellschaft wird eine solche Ehe als peinlich angesehen. Am passendsten findet man Ehen unter Gleichfarbigen.

\section{Seite 49}

Dunklere Männer werden akzeptiert, wenn ihr sozialer Status über demjenigen der helleren Frau liegt.

- Einige Sprichwörter:
- Eu tento esclarecer os pretos aqui, que há mesmo um racismo brasileiro.

- Avalia-se a cota de pretos no Brasil em 75 a

85 por cento. Na Bahia há menos que 1 por cento de puros brancos. No entanto: nenhum professor universitário é negro, há só um padre católico negro e doze médicos pretos. Até hoje, nos hotéis de luxo da cidade negros são vistos com dureza ou lhes dão a informação: nós estamos lotados.

Nas melhores escolas da cidade não há lugar para crianças pretas.

- Aliás, há um arquiteto preto na cidade.

- Bahia tem cinco clubes elegantes: o Português, o Esporte, o Atlético, o late Club e o Tenis Club. Em nenhum é admitido um negro, a não ser como limpador de janela ou ajudante de cozinha.

Nos bancos da Bahia, o Senhor não vê um funcionário preto - no máximo a telefonista - e ela não é visível ao público.

Em anúncios, são procurados funcionários com aparência "agradável".

- Há no Brasil até hoje cartuns que propagam a imagem do preto, como foi difundida nos EUA durante os anos vinte:

O negro com grandes olhos enrolando.

- Em 6 de janeiro de 1970, a revista ilustrada "Manchete" publicou uma piada, na qual uma branca se casa com um "gorila" de Ghana.

- Sim, no Brasil pretos e brancos podem se casar, mas na sociedade, tal casamento é visto como embaraçoso. Acha-se mais adequado casamentos entre os da mesma cor.

\section{Página 49}

Homens mais escuros são aceitos, quando seu status social está acima do de suas mulheres mais claras.

- Alguns ditados: 
Ein Weisser, der läuft, ist ein Sportler, ein Schwarzer ein Dieb!

Ein Weisser mit einer Aktentasche ist ein Arzt, ein Schwarzer mit einer Aktentasche ist ein Betrüger!

Ein Schwarzer soll das Haus eines Weissen nur betreten, wenn er daran baut!

- Ich sehe in der übertriebenen Publicity, die dem Fussballstar Pelé und anderen schwarzen Sportlern, Künstlern auch, gegeben wird, nur ein gezieltes Ablenkungsmanöver der herrschenden brasilianischen Gesellschaft.

- Unter der schwarzen Bevölkerung, besonders im Candomblé, bildet sich jetzt eine fast mythische Verehrung alles Afrikanischen heraus, die aber auch nicht aufklärerisch wirkt. Es ist mir passiert, dass mich hellhäutige Neger in Bahia anderen gleichhellen mit der Bemerkung vorstellten:

- Er ist aus Ghana!

um meine Prestige $\mathrm{zu}$ heben und $\mathrm{zu}$ entschuldigen, dass sie mit einem dunkler gefärbten verkehren.

Am Dienstag, dem 29. Dezember 1970, bildete die Illustrierte „O Cruzeiro“ im redaktionellen Teil 540 Personen deutlich ab; davon 50 Mulatten oder Neger:

1 unkenntlich.

1 von hinten.

4 in einer Gruppe von 12.

5 in einem Zeichentrickfilmstreifen.

3 in der Mode.

18 in einer Afrikareportage.

2 in einer Fussballgruppe.

1 Diener.

1 Komponisten.

2 Verbrecher.
Um branco correndo é um esportista, um preto, um ladrão!

Um branco com uma pasta é um médico, um preto com uma pasta é um impostor!

Um preto deve pisar na casa de um branco só quando ele trabalha na construção!

- Eu vejo na exagerada Publicity que é dada à estrela do futebol Pelé e a outros esportistas pretos, a artistas também, somente uma manobra orientada de distração da sociedade brasileira dominante.

- Na população preta, especialmente no candomblé, desenvolve-se agora uma adoração quase mítica de tudo que é africano, mas que não tem um efeito esclarecedor.

Aconteceu comigo, que um negro de pele clara na Bahia me apresentou a outro, igualmente claro, com a observação:

- Ele é de Ghana!

para aumentar meu prestígio e se desculpar, que ele se relacione com alguém de pele escura.

Na terça-feira, 29 de dezembro de 1970, a revista ilustrada "O Cruzeiro", na seção editorial, retratou nitidamente 540 pessoas; entre eles, 50 mulatos ou negros:

1 irreconhecível.

1 por trás.

4 em um grupo de 12.

5 em uma tira de desenho animado.

3 no ramo da moda.

18 em uma reportagem sobre a África.

2 em uma equipe de futebol.

1 criado.

1 compositor.

2 criminosos. 
4 Fussballer.

7 im Hintergrund.

1 Heiligen König im Krippenbild.

\section{Seite 50}

Weniger als 10 Prozent bei einem Bevölkerungsanteil von mehr als 75 Prozent.

In der Reklame kein Neger oder Mulatte.

„Manchete" vom Sonnabend, den 16. Januar 1971:

500 deutlich abgebildete Personen im redaktionellen Teil; davon 73 Neger oder Mulatten:

1 verdeckt.

3 Fussballer.

1 Fussballer.

15 im Candomblé.

20 im Candomblé.

16 im Candomblé.

1 Ministrant.

4 im Candomblé.

1 Schauspieler.

3 Sambatänzer.

1 Angestellter.

2 in einer Gruppe.

Präsident François Duvalier und haitianische Politiker.

2 Schauspieler.

In der Reklame kein Neger oder Mulatte.

"O Cruzeiro" vom Mittwoch, den 20. Januar:

340 deutlich abgebildete Personen; davon 9 Neger oder Mulatten:
4 futebolistas.

7 no fundo.

1 Rei Mago na figura de presépio.

\section{Página 50}

Menos que 10 por cento de uma percentagem de população de mais que 75 por cento.

No reclame, nenhum negro ou mulato.

"Manchete" de sábado, 16 de janeiro de 1971:

500 pessoas nitidamente retratadas na seção editorial; entre elas, 73 negros ou mulatos:

1 encoberto.

3 futebolistas.

1 futebolista.

15 no candomblé.

20 no candomblé.

16 no Candomblé.

1 coroinha.

4 no candomblé.

1 ator.

3 dançarinos de samba.

1 empregado.

2 em um grupo.

Presidente François Duvalier e políticos haitianos.

2 atores.

No reclame, nenhum negro ou mulato.

"O Cruzeiro" de quarta-feira, 20 de janeiro:

340 pessoas nitidamente retratadas; entre elas 9 negros ou mulatos: 
2 Mechaniker.

6 Fussballer.

4 Sambatänzer.

2 Boxer.

4 Schauspieler.

1 Bischof.

In der Reklame kein Neger oder Mulatte.

"Manchete" vom Sonnabend, den 23. Januar:

Im redaktionellen Teil 350 deutlich abgebildete

Personen; davon 33 Neger oder Mulatten:

8 in einer Afrikareportage.

1 Fussballer.

2 Kinder.

4 Boxer.

4 Arbeiterinnen.

\section{Seite 51}

Malcom X.

1 Arbeiter.

12 in einer Gruppe.

Eine Mulattin wirbt für Helena Rubinstein.

Der „Estado de São Paulo“ veröffentlicht eine Werbeanzeige:

Ich traue Brastel,

Denn Brastel macht es simpel.

Denn Brastel gibt Kredit.

Denn Brastel ist prima!

Eisschränke, Elektrolas, Waschmaschinen, Nähmaschinen, Fernseher, Sitzdecken, Schlafzimmer.

Wer vertraut da in Brastel?
2 mecânicos.

6 futebolistas.

4 dançarinos de samba.

2 boxeadores.

4 atores.

1 bispo.

No reclame, nenhum negro ou mulato.

"Manchete de sábado, 23 de janeiro:

$\mathrm{Na}$ seção editorial, 350 pessoas nitidamente retratadas; entre elas, 33 negros ou mulatos:

8 em uma reportagem sobre a África.

1 futebolista.

2 crianças.

4 boxeadores.

4 trabalhadoras.

\section{Página 51}

Malcom X.

1 trabalhador.

12 em um grupo.

Uma mulata faz anúncio da Helena Rubinstein.

O "Estado de São Paulo" publica um anúncio publicitário:

Eu confio na Brastel,

Pois Brastel facilita.

Pois Brastel dá crédito.

Pois Brastel é ótima!

Geladeiras, eletrolas, máquinas de lavar, máquinas de costura, televisores, assento para cadeira, dormitórios.

Quem confia aí na Brastel? 
Ein gutmütiger, ein dämlich blickender Neger mit querstehenden Zähnen, die ihm für die Reklame übergestülpt worden sind.

Ich lerne einen pensionierten Hauptmann kennen, der an der Verfolgung des Räubers Lampião teilgenommen hat.

1938 machte man Lampião und seine Bande im Nordosten ausfindig. Alle wurden erschossen und den Erschossenen schnitt man die Köpfe ab.

Lampião - Lampioon - küsste keine Birken; er wurde von seinen Verfolgern als grosser Stratege geachtet, meint der Hauptmann.

Geachtet, was heisst das?

Das ganze Heer musste aufgeboten werden, um inn zu erlegen.

Die Spiritisten glauben, er sei eine Inkarnation von Napoleon gewesen.

- Einer von Lampiãos Banditen hatte einen Bauernhof überfallen.

Er tötete unter den Augen der schwangeren Frau ihren Mann, hielt ihr das Messer unter den Hals. Sie hatte eine Sturzgeburt.

Der Bandit tötete das Neugeborene und die Mutter. Er wurde zu 30 Jahren Gefängnis verurteilt, begnadigt und schliesslich entlassen. Er arbeitet heute im öffentlichen Dienst.

***

Unser Vermieter war 16 Jahre alt, als die Köpfe von Lampião und seiner Bande in Alagoas ausgestellt wurden.

Die Polizisten transportierten sie in Blechkästen voller Formol und zogen die Köpfe an den Haaren heraus, um sie der Menge zu zeigen.

\section{Seite 52}

Mit den Banküberfällen mehren sich auch die schneidig angezogenen Mulatten von privaten
Um negro bondoso, um negro de olhar estúpido com dentes atravessados que lhe foram sobrepostos para o reclame.

Eu fico conhecendo um capitão aposentado que participou da perseguição do ladrão Lampião.

1938 localizaram Lampião* e seu bando no nordeste. Todos foram fuzilados e aos fuzilados cortaram-Ihes a cabeça.

Lampião - Lampion - não beijava bétulas; ele foi respeitado por seus perseguidores como grande estrategista, acha o capitão.

Respeitado, o que significa isso?

O exército inteiro teve que ser convocado para abatê-lo.

Os espíritas acreditam que ele seria a encarnação de Napoleão.

- Um dos bandidos de Lampião assaltou uma fazenda.

Ele matou diante dos olhos da mulher grávida seu marido, segurou-lhe a faca sob seu pescoço. Ela teve um parto precipitado.

O bandido matou o neonato e a mãe. Ele foi condenado a 30 anos de prisão, indultado e, por fim, solto. Ele trabalha hoje no serviço público.

$\star * *$

Nosso locador tinha 16 anos, quando as cabeças de Lampião e seu bando foram expostas em Alagoas.

Os policiais transportaram-nas em caixas de lata cheias de formol e puxadas pelos cabelos para mostrá-las à multidão.

\section{Página 52}

Com os assaltos a bancos, aumentam também os mulatos das companhias de vigilância e 
Wach- und Schliessgesellschaften, die das Kapital der Weissen unter dem Risiko, zusammengeschossen zu werden, bewachen dürfen.

Das Publikum, das die Bank betritt, hat blanke Schuhe, frische Wäsche; die Männer tragen einen Diplomatenkoffer, die Frauen kommen gerade vom Friseur.

Eine alte Frau mit umwickelten Beinen geht langsam in den vornehmsten Teil der Bank, wo MillerCollection zum Warten bereitsteht und die wichtigeren Angestellten an umfangreicheren Schreibtischen sitzen.

Die etwa achtzigjährige Frau stellt sich in der gebührenden Entfernung vor den Schreibtisch des wichtigeren Angestellten. Der Angestellte ist derart von seinen Aufgaben absorbiert, dass es inm nicht gelingt, im Laufe einer halben Stunde, im Laufe von 30 Minuten, im Laufe von 1.800 Sekunden - 21, 22 auch nur einmal die Greisin mit den umwickelten Beinen anzusehen oder ihr einen Millersessel anzubieten.

Der Pressechef des Gouverneurs ist ein wichtiger Mann.

Betritt er den Raum, vollführt sein Sekretär kleine Bewegungen mit der Hand, dass die ausländische Fotografin sich erhebe.

Der Pressechef kann einen erstaunen Ausdruck im Gesicht nicht verbergen, als die ausländische Fotografin sitzenbleibt.

Der Presschef wirft Papiere, die er nicht mehr benötigt, zerknüllt auf den Teppich und alle Viertelstunde kommt eine Afrikanerin, rutscht auf den Knien nach den zerknüllten Papieren und wirft sie in einen Papierkorb.

Der neue Gouverneur tritt sein Amt an. segurança privadas, com trajes alinhados, que podem vigiar o capital dos brancos sob o risco de serem mortos a tiros.

O público que entra no banco tem sapatos polidos, roupas limpas; os homens carregam uma mala de executivo, as mulheres acabam de vir do cabeleireiro.

Uma velha mulher com pernas enfaixadas vai devagar à parte mais requintada do banco, onde a Coleção Miller está à disposição para a sala de espera e os funcionários mais importantes estão sentados nas amplas mesas de escritório.

A senhora de cerca de oitenta anos coloca-se na devida distância diante da mesa de escritório do funcionário mais importante. O funcionário está de tal modo absorvido pelas suas tarefas, que não the é possível, no decorrer de uma meia hora, no decorrer de 30 minutos, no decorrer de 1.800 segundos $-21,22$, olhar sequer uma vez a anciã com a perna enfaixada ou oferecer-lhe uma poltrona Miller.

***

O chefe de imprensa do governador é um homem importante.

Quando ele entra na sala, seu secretário executa um pequeno movimento com a mão, para que a fotógrafa estrangeira se erga.

O chefe de imprensa não pode esconder uma expressão de espanto no rosto, quando a fotógrafa estrangeira continua sentada.

O chefe de imprensa joga papéis, de que ele não mais necessita, amassados no tapete e a cada quarto de hora vem uma africana, arrasta-se de joelhos atrás dos papéis amassados e joga-os no cesto de papel.

O novo governador assume seu cargo. 
Welch delikate Situation für die Freunde des alten, die den neuen brauchen, die nicht als Schmeichler erscheinen mögen.

Die Künstler, die Kommunisten, die rosa Künstler senden jetzt Druckgraphiken an den neuen, wie sie ehemals Druckgraphiken an den alten sandten; und die Dichter und Sänger singen und

\section{Seite 53}

dichten für den Liebling des Militärs, wie sie ehemals dichteten und sangen für den als liberal geltenden scheidenden.

Alle sie handeln in richtiger Einschätzung der Lage:

Wer nähme sie noch ernst?

\section{***}

Der Motel-Club inseriert in den Tageszeitungen:

Vielen Dank, Herr Gouverneur, Luis Viana Filho, für alles, was Sie für unser geliebtes Bahia getan haben.

Vielen Dank, Herr Gouverneur, Antonio Carlos Magalhaes, für die glänzende Hoffnung auf Fortschritt, die sie bringen!

Das Entbindungsheim Tsyla feiert sein 15jähriges Bestehen.

Es ist das einzige Entbindungsheim für die Armen in der Stadt Bahia.

Feldbetten stehen in den Korridoren.

Die meisten Betten sind mit zwei Müttern belegt.

Die Wöchnerinnen müssen 24 Stunden nach der Geburt das Entbindungsheim wieder verlassen.
Que situação delicada para os amigos do antigo, que precisam do novo, que não querem parecer bajuladores.

Os artistas, os comunistas, os artistas rosa enviam agora gravuras ao novo, como eles anteriormente enviaram gravuras ao antigo; e os poetas e cantores cantam e

\section{Página 53}

poetam para o preferido do militar, como eles anteriormente poetavam e cantavam para o cessante, considerado liberal.

Todos eles agem na avaliação correta da situação:

Quem ainda os leva a sério? ***

O Motel-Club anuncia nos jornais diários:

muito obrigado, Senhor Governador, Luis Viana Filho, por tudo o que o Senhor fez pela nossa querida Bahia.

Muito obrigado, Senhor Governador, Antonio Carlos Magalhaes, pela brilhante esperança de progresso que o Senhor traz!

***

A casa de parto Tsyla comemora seus 15 anos de existência.

É a única casa de parto para os pobres na cidade da Bahia.

Camas de campanha estão nos corredores.

A maioria das camas estão ocupadas com duas mães.

As parturientes têm que deixar novamente a casa de parto 24 horas depois do nascimento. 
Freitag, den 19. März:

Jornal do Brasil:

Bahianisches Gericht verhängt erstes Todesurteil in Brasilien seit Schaffung der Republik.

Der neunzehnjährige Teodomiro Romeiro dos Santos wurde am 18. März 1971 um 17 Uhr 10 von einem militärischen Sondergericht zum Tode verurteilt, der 26jährige Paulo Pontes da Silva zu lebenslänglicher Haft.

Teodomiro und Paulo waren am 27. Oktober als Terroristen festgenommen worden und mit Handschellen gefesselt.

Teodomiro gelang es, einen Revolver aus der Tasche zu holen und einen Polizisten zu erschiessen. Paulo sass gefesselt daneben.

Der Ankläger, Antonio Brandão de Andrade, der vor seiner anderthalbstündigen Anklagerede das Zeichen des Kreuzes machte, äusserte:

\section{Seite 54}

-Bescheidenheit beiseite, meine Anklagerede war ausgezeichnet.

Vielleicht die beste meines Lebens.

Der neunzehnjährige Teodomiro bat, bei der Urteilsverkündung nicht anwesend sein zu müssen.

Paulo Pontes da Silva teilte Journalisten in einer Verhandlungspause mit, dass er während der Untersuchungshaft Misshandlungen ausgesetzt war.

Im Quartel do Barbalho sei er wiederholt gefoltert worden.

Die Angeklagten können Berufung gegen das Urteil einlegen. Aber es findet sich kein Rechtsanwalt in Bahia, der es wagte, den neunzehnjährigen Teodomiro zu verteidigen und zu verhindern, dass der gefesselt der Tat
Sexta-feira, 19 de março:

Jornal do Brasil:

Tribunal bahiano impõe primeira sentença de morte no Brasil desde a criação da República.

Teodomiro Romeiro dos Santos, de dezenove anos, foi sentenciado à morte no dia 18 de março de 1971 às 17:10 $\mathrm{h}$ por um tribunal militar especial, Paulo Pontes da Silva, de 26 anos, à prisão perpétua.

Teodomiro e Paulo foram detidos em 27 de outubro como terroristas e presos com algemas.

Teodomiro conseguiu pegar um revolver da bolsa e atirar em um policial. Paulo estava sentado ao lado, preso.

O promotor, Antonio Brandão de Andrade, que fez o sinal da cruz antes de seu discurso de acusação, manifestou:

\section{Página 54}

-Modéstia a parte, meu discurso de acusação foi notável.

Talvez o melhor da minha vida.

Teodomiro, de dezenove anos, pediu para não ter que estar presente na proclamação da sentença.

Paulo Pontes da Silva comunicou a jornalistas na pausa da audiência, que durante a prisão preventiva foi exposto a maus tratos.

No Quartel do Barbalho ele teria sido torturado repetidamente.

Os acusados podem interpor recurso contra a sentença. Mas não se encontra nenhum advogado na Bahia que ouse defender Teodomiro, de dezenove anos, e evitar que Paulo, preso e observando o fato, tenha que, inocente, ir pelo resto da sua vida para a prisão. 
zusehende Paulo unschuldig den Rest seines Lebens ins Gefängnis muss.

Fahrt nach Irece in das Dürregebiet im Staate Bahia:

Vor Feira Sant'Ana elende Hütten um eine Zuckermühle.

Vor Jacobina ein Tümpel, wo die Frauen Wasser holen.

Auf der Strasse ein verdurstetes Rind. Hunde und Geier fressen daran.

In Jacobina wird ein offener Sarg mit einer Kinderleiche zum Friedhof getragen.

Von Jacobina nach Irece verkehrt ein Jeep als Gemeinschaftstaxi.

Vollgepfropte Lastwagen fahren uns entgegen - die Arbeiterfamilien werden in den Norden zurücktransportiert.

An einem Stop eine Familie mit vier Kindern.

Die Frau trägt einen Säugling. Fliegen saugen sich an seinen Lidrändern fest.

Der Mann war aus dem Norden gekommen, um in Irece Arbeit zu finden. Er hat eine Woche herumvegetiert und macht sich jetzt auf den Rückweg, denn das Gerücht verbreitet sich, im Norden habe es geregnet. Regen bedeutet Arbeit. Er hat kein Geld mehr. Die Familie ist zu Fuss. Sie haben tausend Kilometer vor sich. Er schwingt das riesige Zuckerrohrmesser und lächelt. Wie lange hat er noch die Kraft, es hin und her zu schwingen?

In Irece steht ein Lastwagen, auf dessen Pritsche Bänke montiert sind. So dicht, dass etwa 90 Personen darauf gepfercht werden können. Die Fahrt nach Pernambuco zurück kostet 20 Cruzeiros, weniger als 14 Mark. Die Präfektur gibt zwei Cruzeiros,
Viagem a Irece, à região da seca no estado da Bahia:

Antes de Feira Sant'Ana, cabanas miseráveis ao redor de um moinho de açúcar.

Antes de Jacobina, um charco onde as mulheres apanham água.

Na rua, um boi que morreu de sede. Cachorros e abutres devoram-no.

Em Jacobina, um caixão aberto, com um cadáver de criança, é carregado para o cemitério.

De Jacobina a Irece transita um Jeep como táxi comunitário.

Caminhões abarrotados passam em direção contrária à nossa - as famílias dos trabalhadores são transportadas de volta para o norte.

Num Stop, uma família com quatro filhos.

A mulher carrega um nenê. Moscas sugam firmemente em suas pálpebras

O homem veio do norte, para encontrar trabalho em Irece. Ele vegetou por ali uma semana e coloca-se agora no caminho de volta para casa, pois o rumor se espalha, de que no norte choveu. Chuva significa trabalho. Ele não tem mais dinheiro. A família está a pé. Eles tem mil quilômetros pela frente. Ele balança a enorme faca de cana-de-açúcar e sorri. Quanto tempo ele ainda terá a força de balançá-la para lá e para cá?

Em Irece está parado um caminhão, em cuja carroceria estão montados bancos. Tão compacto que cerca de 90 pessoas podem ser encurraladas neles. A viagem de volta a Pernambuco custa 20 cruzeiros, menos que 14 marcos. A prefeitura dá dois cruzeiros, 


\section{Seite 55}

eine karitative Vereinigung nochmal zwei; den Rest müssen sich die Arbeitslosen aus den Rippen schneiden.

Ein zwölfjähriger Junge hat seine Familie verloren. Sie ist auf irgendeinem anderen Laster zurücktransportiert worden.

Er läuft weinend herum und bettelt die Elenden an.

Ihm fehlen zehn Mark.

Ein Händler aus Irece sagt:

- Die Gemeinde hat 70 bis 80.000 Einwohner.

- Von der Dürre sind hier in der Region etwa 200.000 Menschen betroffen.

Ein paar hundert Familien besitzen zwischen tausend und zweitausend Hektar Land. Das wird in Brasilien nicht als Grossgrundbesitz angesehen.

- Die meisten Bauern haben Anwesen von 20 bis 50 Hektar hier in der Gegend. Nicht nur Ackerland. Es sind auch Weiden dabei.

- Die meisten Familien, die aus dem Norden einwandern, wollen sich hier fest ansiedeln.

- Vor fünf Jahren hatte Irece Stadt 6.000 Einwohner. Heute sind es 16.000.

- Vor einem Jahr fehlten hier die Arbeitskräfte. Die Besitzer zahlten bis zu 6 Cruzeiros für acht Stunden Arbeit am Tag, 4 Mark.

- Die Regenzeit ist von März bis Oktober.

- Dieses Jahr ist der Mais verdorrt. Die erste Bohnensaat auch. Wer ein zweites Mal Bohnen gesät hat, könnte vielleicht noch was ernten.

- Die Armen sind natürlich am meisten getroffen. Aber auch die Begüterten haben Schwierigkeiten bei den Banken.

\section{Página 55}

uma associação caritativa mais dois; o resto, os desempregados têm que tirar das costelas.

Um menino de doze anos perdeu sua família. Ela foi transportada de volta por qualquer outro caminhão.

Ele anda por ali chorando e pede esmolas aos miseráveis.

Faltam-lhe dez marcos.

$* * *$

Um comerciante de Irece diz:

- A comunidade tem de 70 a 80.000 habitantes.

- Pela seca, aqui na região são afetadas cerca e 200.000 pessoas.

Algumas centenas de famílias possuem entre mil e dois mil hectares de terra. Isso no Brasil não é visto como uma grande propriedade de terras.

- A maioria dos camponeses tem terrenos de 20 a 50 hectares aqui na redondeza. Não somente terras aráveis. Há também pastos neles.

- A maioria das famílias que imigram do norte querem estabelecer residência fixa aqui.

- Há cinco anos, a cidade de Irece tinha 6.000 habitantes. Hoje são 16.000.

- Há um ano faltavam aqui forças de trabalho. Os proprietários pagavam até 6 cruzeiros por oito horas de trabalho por dia, 4 marcos.

- O tempo de chuva é de março a outubro.

- Esse ano o milho secou. A primeira semente de feijão também. Quem uma segunda vez semeou feijões, talvez ainda possa colher algo.

- Os pobres são, naturalmente, os mais atingidos. Mas também os abastados têm dificuldades com os bancos. 
- Bis heute sind 3.000 Saisonarbeiter aus dem Norden zwangsweise zurücktransportiert worden. Wieviele hergezogen sind, kann ich nicht sagen. Viele sind am Strassenrand gestorben und ohne Totenschein auf den Feldern eingescharrt worden.

- Die meisten Geburten werden nicht eingetragen.

Kinderkrankheiten, Deshydratation, Vitaminmangel, Wurmbefall sind hier am häufigsten. Beulenpest wird durch den Rattenfloh übertragen. Ratten sind wegen des Mais hier häufig.

Rattenvernichtung stinkt. Das mögen die Leute nicht.

In einigen Dörfern sind 30 Prozent der Bevölkerung lungenkrank.

\section{Seite 56}

- Lepra gibt es auch. Die Kranken werden in kleinen Laubhütten auf den Feldern versteckt.

- Der Sklavenhandel ist noch nicht zu Ende. Voriges Jahr kam ein Lastwagenfahrer aus Pernambuco mit Leuten, die in Irece arbeiten wollen. Sie hatten nicht genügend Geld, um die Reise zu bezahlen. Der Fahrer sprach mit einigen Fazendeiros, die bezahlten inm das Fahrgeld für die Passagiere und eine Prämie pro Kopf. Er lieferte die Leute ab. Sie waren auf Grund der Schulden den Fazendeiros rechtlos ausgeliefert.

- Hier ist es nicht üblich, den fest angestellten Landarbeitern einen Lohn zu zahlen. Wenn sie Kleidung oder Medikamente benötigen, wenden sie sich an den Fazendeiro und der gibt innen das Dringendste. Auf diese Weise hält der Landbesitzer die Arbeiter in völliger Abhängigkeit und spart.

- Das Brunnenwasser in Irece ist kalkhaltig und zerstört die Gare des Bodens. Es ist mit Amöben und Würmern verseucht.
- Até hoje 3.000 trabalhadores sazonais do norte foram forçosamente transportados de volta. Quantos se mudaram para cá, não sei dizer. Muitos morrreram na beira da estrada e foram enterrados sem certidão de óbito nos campos.

- A maioria dos nascimentos não são registrados.

- Doenças de criança, desidratação, falta de vitamina, infestação de vermes são aqui os mais frequentes. Peste bubônica é transmitida pela pulga do rato. Ratazanas são frequentes aqui, devido ao milho.

A aniquilação de ratos fede. Disso as pessoas não gostam.

Em alguns vilarejos, 30 por cento da população é doente do pulmão.

\section{Página 56}

- Lepra há também. Os doentes são escondidos em pequenas barracas de folhagens nos campos.

- O comércio de escravos ainda não chegou ao fim. Ano passado veio um motorista de caminhão de Pernambuco com pessoas que queriam trabalhar em Irece. Eles não tinham dinheiro suficiente para pagar a viagem. $O$ motorista falou com alguns Fazendeiros, que pagaram-no o dinheiro da passagem para os passageiros e um prêmio por cabeça. Ele entregou as pessoas. Eles ficaram, devido às dívidas, sem direitos, à mercê dos Fazendeiros.

- Aqui não é comum pagar um salário aos trabalhadores rurais permanentes. Quando eles necessitam de roupa ou medicamentos, dirigemse ao Fazendeiro e ele lhes dá o mais premente. Dessa maneira mantém o proprietário rural os trabalhadores em completa dependência e economiza.

- A água de poço em Irece é de conteúdo calcário e destrói o estado grumoso do solo. Ela é contaminada com amebas e vermes. 
Das Regenwasser aus den Tümpeln ist noch gefährlicher. Übrigens leben die Erwachsenen ganz gut mit Amöben. Wer als Kind nicht daran zugrunde geht, braucht sie nicht mehr zu fürchten.

- Es gibt hier eine kostenlose medizinische Betreuung. Die Patres sind daran beteiligt. Deshalb kommen die Leute auch ohne Misstrauen.

- Auf die ca. 70000 Einwohner der Gemeinde Irece kommen vier Ärzte. Aber wer kann sich schon einen Arzt leisten.

- Eine Hebamme registrierte bei 150 Geburten 75 Totgeburten.

In der Stadt gibt es ungefähr 250 Prostituierte.

- In Brasilien kann man sich nicht scheiden lassen. Oft lassen sich die Männer einmal kirchlich trauen und ein zweites Mal mit einer zweiten Frau standesamtlich.

- Die Frau wird wie eine Sklavin gehalten. Der Mann darf alles, die Frau nichts. Sie soll arbeiten und Kinder kriegen.

Manche Frauen haben in ihrem Leben zwanzig Geburten. Die Hälfte der Kinder werden gross.

Die Familien haben wenigstens sechs Kinder.

- Es gibt keine Sozialversicherung.

- Die Müttersterblichkeit ist gross.

- Die Lebenserwartung liegt hier bei 47 Jahren etwa.

- Homosexualität kommt nicht vor.

- Nur 50 Prozent der schulpflichtigen Kinder könnten einen Schul-

\section{Seite 57}

platz finden, vorausgesetzt, dass die Eltern die Kinder in die Schule schicken. Als Lehrerinnen arbeiten irgendwelche, kaum vorgebildete
A água da chuva das poças é ainda mais perigosa. Aliás, os adultos vivem muito bem com amebas. Quem não sucumbiu a elas quando criança, não precisa mais temê-las.

- Há aqui uma assistência médica sem custo. Os padres estão envolvidos nisso. Por esse motivo, as pessoas também vêm sem desconfiança.

- Para cerca de 70.000 habitantes da comunidade de Irece há quatro médicos. Mas quem pode se dar ao luxo de pagar um médico.

- Uma parteira registrou entre 150 nascimentos 75 nascimentos de crianças mortas.

$\mathrm{Na}$ cidade há aproximadamente 250 prostitutas.

- No Brasil não se pode divorciar. Frequentemente os homens se casam uma vez no religioso e uma segunda vez com uma segunda mulher civilmente.

- A mulher é mantida como uma escrava. O homem pode tudo, a mulher nada. Ela devem trabalhar e ter filhos.

Algumas mulheres têm em suas vidas vinte partos. A metade das crianças tornam-se adultos.

As famílias têm no mínimo seis filhos.

- Não há um seguro social.

- A mortalidade das mães é grande.

- A expectativa de vida é de cerca de 47 anos.

- Homossexualidade não ocorre.

- Só 50 por cento das crianças sujeitas à obrigatoriedade escolar poderiam

\section{Página 57}

achar uma vaga escolar, contanto que os pais mandem as crianças para a escola. Como professoras trabalham quaisquer moças, quase 
Mädchen. Schule findet einmal in der Woche statt.

Es gibt in der Gemeinde Irece fünf Gymnasien. Sie kosten 10 bis 30 Cruzeiros im Monat. In der Stadt Irece besuchen 300 Schüler das Gymnasium, 50 Schüler besuchen Abendkurse - das sind alles in allem 5 Prozent der begabten Schüler.

- Das Essen der Arbeiter besteht aus Reis, Mais und Bohnen. Gelegentlich Pökelfleisch. Es herrscht allgemein Vitaminmangel.

- Von den Ansässigen verhungern wenige.

- Die Saisonarbeiter leben hauptsächlich von Kaktusfeigen.

- Die Arbeiter lesen nicht. Früher kam nicht mal die Zeitung nach Irece.

- Die meisten sind Katholiken. Oberflächlich. Es gibt auch Protestanten, Spiritisten und natürlich den Candomblé.

- Um die ansässigen Arbeiter auch in Notzeiten beschäftigen zu können, wurden die Frentes de Trabalho aufgestellt. Gab es in der Landwirtschaft keine Arbeit, wurden sie auf dem Bau beschäftigt. Sie bekamen dann zwei Cruzeiros am Tag - etwa eine Mark vierzig. Jetzt bei der Trockenheit werden alle Rücklagen verbraucht und niemand beginnt mit neuen Bauvorhaben.

- Auf den Fazendas gibt es keine körperlichen Strafen mehr.

- Alkoholismus ist häufig.

- Weniger Verbrechen als sonst unter der Landbevölkerung.

- Häufiger Idiotismus. Erbanlagen. Inzucht. Syphilis. Alkohol.

- In Irece Stadt gibt es fünf Polizisten. Jeder Arbeiter, der auf das Polizeikommissariat gebracht wird, kriegt erst mal Prügel. sem preparação. Escola acontece uma vez por semana.

Há na cidade de Irece cinco ginásios. Eles custam de 10 a 30 cruzeiros por mês. Na cidade de Irece frequentam 300 alunos o ginásio, 50 alunos frequentam o curso noturno - esses são ao todo 5 por cento dos alunos dotados.

- A comida dos trabalhadores consiste de arroz, milho e feijão. Ocasionalmente carne salgada. Predomina falta geral de vitamina.

- Dos residentes, poucos passam fome.

Os trabalhadores sazonais vivem principalmente de figos de cacto.

- Os trabalhadores não leem. Antigamente, nem mesmo o jornal vinha para Irece.

- A maioria são católicos. Superficialmente. Há também protestantes, espíritas e naturalmente o Candomblé.

- Para poder ocupar os trabalhadores permanentes também em tempos de necessidade, foram estabelecidas as Frentes de Trabalho. Se não houvesse trabalho na agricultura, eles eram empregados na construção. Eles recebiam então dois cruzeiros por dia - aproximadamente um marco e quarenta. Agora, na seca, todas reservas são utilizadas e ninguém começa com novos projetos de construção.

- Nas Fazendas não há mais penas corporais.

- Alcoolismo é frequente.

- Menos crimes que antes entre a população rural.

- Idiotismo frequente. Herança genética. Endogamia. Sífilis. Álcool.

- Na cidade de Irece há cinco policiais. Cada trabalhador que for levado à delegacia de polícia ganha primeiro uma surra. 
Mit dem Knüppel. Oft werden die Leute blutig geschlagen.

Antworten eines Arztes aus Irece:

- Irece Stadt hat 15000 Einwohner, die Gemeinde 60 000. Auf diese 60000 kommen sechs Ärzte, nicht vier.

- Im ersten Lebensjahr sterben hier 70 Prozent der Säuglinge. 50 Prozent der Kinder erreichen das Erwachsenalter. Die Müttersterblichkeit liegt bei 20 Prozent.

-Typhus und Beulenpest treten epidemisch auf. Pest auch endemisch.

\section{Seite 58}

- 90 Prozen der Kinder haben Amöben. Lepra tritt mehr in den angrenzenden Regionen auf aber auch hier.

- Das Tetrex aus den Apotheken muss alles heilen.

- Pocken werden durch die Gastarbeiter aus Pernambuco eingeschleppt. Besonders häufig ist, die viszerale Leishmaniasis. Parasiten blähen den Leib auf. Milz, Leber, Knochenmark werden befallen. Ohne Behandlung endet die Krankheit nach einigen Monaten tödlich. Die Chagaskrankheit ist verbreitet. Sie wird durch die Raubwanze übertragen und ruft Veränderung an Herz, Leber und Milz hervor. Eine wirksame Therapie ist immer noch nicht gefunden.

\section{- Durch Unterernährung hervorgerufene} Rachitis.

\footnotetext{
Alle Reichen benützen hier empfängnisverhütende Mittel, 50 Prozent der Mittelklasse, aber nur 10 Prozent der armen Bevölkerung.
}

Com o cacetete. Frequentemente as pessoas são espancadas até sangrar.

$\star * *$

Resposta de um médico de Irece:

- A cidade de Irece tem 15.000 habitantes, a comunidade 60.000 . Para os 60.000 há seis medicos, não quarto.

- No primeiro ano de vida morrem aqui 70 por cento dos lactentes. 50 por cento das crianças alcançam a idade adulta. A mortalidade das mães é de 20 por cento.

- Tifo e peste bubônica ocorrem epidemicamente. Peste também endemicamente.

\section{Página 58}

- 90 por cento das crianças tem amebas. Lepra ocorre mais nas regiões fronteiriças - mas também aqui.

- O Tetrex das farmácias tem que curar tudo.

- Varíola é introduzida pelos trabalhadores convidados de Pernambuco. De especial frequência é a leishmaniose visceral. Parasitas incham o corpo. Baço, fígado, medulla são afetados. Sem tratamento, a doença tem, após alguns meses, desfecho fatal. A doença de Chagas está disseminada. Ela é transmitida através do barbeiro e provoca mudanças no coração, fígado e baço. Uma terapia eficar einda não foi encontrada.

- Raquitismo provocado por subnutrição.

- Todos os ricos usam aqui meios para evitar a concepção, 50 por cento da classe media, mas só 10 por cento da população pobre. 
- Ein Fünftel verdienen nicht einmal den gesetzlich festgelegten Mindestlohn, sondern oft weniger als drei Cruzeiros am Tag, zwei Mark.

- Die Lebenskosten in Irece liegen höher als in der Grossstadt Bahia.

- Die Armen wenden sich bei Erkrankung zuerst an den Curador, den Kurpfuscher. Wenn der keine Abhilfe schafft, wenden sie sich an den Apotheker, der innen meistens Tetrex gibt - die Kranken können natürlich ihren Zustand nicht richtig charakterisieren. Im äussersten Fall wenden sie sich an einen Arzt.

- Elektrizität gibt es nur in den Häusern der Mittelklasse.

Monta, den 1. Februar:

Jornal do Brasil:

João Alves Torres Filho, genannt Joãozinho da Gomeia, der »König des Candomblé « fährt nach São Paulo, um eine Einweihungszeremonie zu leiten.

Freitag, den 5. Februar:

Diario de Noticias:

Die Sonne verbrennt alles in Irece. Die Bohnenernte ist völlig zerstört, der Mais vertrocknet.

\section{Seite 59}

Jornal do Brasil:

Joãozinho da Gomeia erleidet einen Herzanfall und wird bewusstlos ins Krankenhaus Las Clinicas in São Paulo eingeliefert.

Seine Mutter, die 82jährige Maria Vitoriana Torres, begleitet inn und zahlreiche Candomblépriester.
- Um quinto não ganha nem mesmo o salário mínimo fixado legalmente, mas frequentemente menos que três cruzeiros por dia, dois marcos.

- Os custo de vida em Irece é mais alto que na grande cidade Bahia.

- Os pobres dirigem-se, em caso de doença, primeiro ao Curador, o curandeiro. Se ele não conseguir remediar, dirigem-se ao farmacêutico, que no máximo lhes dá Tetrex - os doentes não podem, naturalmente, caracterizar corretamente seu estado. Em caso extremo, dirigem-se a um médico.

- Eletricidade só existe nas casas da classe média.

$\star * *$

Segunda-feira, $1^{\circ}$ de fevereiro:

Jornal do Brasil:

João Alves Torres Filho, chamado Joãozinho da Gomeia, o "Rei do candomblé" viaja a São Paulo, para dirigir uma cerimônia de iniciação.

$* * *$

Sexta-feira, 5 de fevereiro:

Diario de Noticias:

O sol queima tudo em Irece. A colheita de feijão está completamente destruída, o milho ressecado.

\section{Página 59}

Jornal do Brasil:

Joãozinho da Gomeia sofre um ataque do coração e é internado no Hospital Las Clinicas em São Paulo.

Sua mãe, Maria Vitoriana Torres, de 82 anos, 0 acompanha, e vários sacerdotes do candomblé. 
Sonnabend, 6 de fevereiro:

Diario de Noticias:

200000 Menschen auf 500 Quadratkilometern sind von der Dürre betroffen.

Die Rinder verdursten.

Hungernde Arbeiter aus dem Nordosten werden für 60 Cruzeiros an Fazendeiros im Süden verkauft. Zweimal im Monat verlassen drei Lastwagen voll den Bundesstaat Sergipe

\section{A Tarde:}

Die Arbeiter werden nach Parana, in den Mato Grosso und nach São Paulo verkauft.

Freitag, den 12. Februar:

A Tarde:

1000 Ausgehungerte besetzen Arapiraca.

600 Ausgehungerte besetzen Craibas.

Dienstag, den 16. Februar:

\section{A Tarde:}

Joãozinho da Gomeia befindet sich in einem aussichtslosen Zustand. Er schwebt zwischen Leben und Tod. Er liegt mit offenen Augen und spricht mit den Anwesenden. Er erkennt niemanden.

Montag, den 1. März:

Jornal do Brasil:

900 Ausgehungerte besetzen vier Märkte in Pesqueira, Pernambuco. Sie rauben 100 Säcke mit Nahrungsmittel.

Dienstag, den 16. März:
Sábado, 6 de fevereiro:

Diario de Noticias:

200.00 pessoas em 500 quilômetros quadrados são atingidos pela seca.

O gado morre de sede.

Trabalhadores famintos do nordeste são vendidos por 60 cruzeiros a Fazendeiros no sul. Duas vezes por mês três caminhões deixam cheios o Estado de Sergipe.

A Tarde:

Os trabalhadores são vendidos ao Parana, ao Mato Grosso e a São Paulo.

***

Sexta-feira, 12 de fevereiro:

A Tarde:

1.000 famintos ocupam Arapiraca.

600 famintos ocupam Craibas.

Terça-feira, 16 de fevereiro:

A Tarde:

Joãozinho da Gomeia encontra-se em uma situação sem perspectiva. Ele oscila entre a vida e a morte. Ele está deitado com olhos abertos e fala com os presents. Ele não reconhece ninguém.

***

Segunda-feira, $1^{\circ}$ de março:

Jornal do Brasil:

900 famintos ocupam quatro mercados em Pesqueira, Pernambuco. Eles roubam 100 sacos de alimentos.

Terça-feira, 16 de março: 
Jornal do Brasil:

Joãozinho da Gomeia wird an einem Gehirntumor operiert. Der Tumor erwies sich als bösartig.

\section{Seite 60}

Donnerstag, den 18. März:

Jornal do Brasil:

200 Ausgehungerte besetzen Parambu und wollen Nahrungmittel aus einer Kaserne rauben. Die Polizei kann es verhindern und nimmt elf der Aufständischen fest.

Freitag, den 19. März:

Um 9 Uhr 30 endet der Todeskampf von Joãozinho da Gomeia.

Er stirbt 56jährig im Krankenhaus Las Clinicas von São Paulo an Gehirnkrebs.

Sonnabend, den 20. März:

Jornal do Brasil:

»Er starb als König des Candomblé.

Er soll als König begraben werden!«

Joãozinho da Gomeia wird in der Medizinischen Fakultät von São Paulo einbalsamiert und in einem Kombiwagen der Präfektur nach Caxias überführt.

Die Leiche trifft um 16 Uhr 05 in seinem Tempel in Duque de Caxias ein. Als der Körper in das Haupthaus, Gonga, gebracht wird, beginnen die Trommeln zu schlagen. Die Zeremonie Sirum beginnt. Der Leichnam ist in eines der Festgewänder des Candomblé, das Abada, gekleidet.
Jornal do Brasil:

Joãozinho da Gomeia é operado de um tumor no cérebro. O tumor revelou-se como maligno.

\section{Página 60}

Quinta-feira, 18 de março:

Jornal do Brasil:

200 famintos ocupam Parambu e querem roubar alimento de uma caserna. A polícia consegue evitar isso e prende onze rebeldes.

***

Sexta-feira, 19 de março:

Às 9:30 horas termina a luta contra a morte de Joãozinho da Gomeia.

Ele morre com 56 anos no Hospital Las Clinicas de São Paulo com câncer no cérebro.

$* * *$

Sábado, 20 de março:

Jornal do Brasil:

"Ele morreu como rei do candomblé.

Ele deve ser enterrado como rei!"

Joãozinho da Gomeia é embalsamado na Faculdade de Medicina de São Paulo e trasladado em um automóvel Kombi da prefeitura para Caxias.

O cadáver chega às 16:05 horas em seu templo em Duque de Caxias. Quando o corpo é levado para a casa principal, Gongá, os tambores começam a bater. A cerimônia Sirum começa. $O$ cadáver é vestido em uma das vestes festivas do candomblé, o abadá. 
Die greise Mutter willigt ein, dass Joãozinho da Gomeia nicht in Bahia, sondern in Caxias beigesetzt wird.

Der Sarg wird auf einen Tisch gestellt. Valentim, der Oga Alabe, der älteste Würdenträger des Tempels, der die Gesänge für lansa und Oxossi kennt, beginnt den Ritus.

Es sind einige der ältesten laorixas von Brasilien anwesend:

Ebame Gifai,

Tião de Irajá,

Djalma de Lau,

Mãe Natalina,

Paulo de Oxossi.

Jetzt muss der Tote entfernt werden und das Oxu.

Der Geist des Toten soll aus dem Körper gelöst werden.

Im Hintergrund steht ein mit einem weissen Tuch bedeckter Stuhl.

Darin sitzt der Egum von Joãozinho da Gomeia und wohnt der Zeremonie bei.

Drei Widder werden geopfert. Tião de Iraja nähert sich der

\section{Seite 61}

Leiche in dem Sarg und giesst etwas Blut über den Kopf des Toten, wäscht ihn anschliessend mit dem Abó, einer Kräutermischung, die zu den Einweihungsriten benützt wird.

Er ritzt den Kopf des Toten an und entfernt das Oxu, den Geist der Götter, der vor 41 Jahren durch den Priester Jubiaba in Bahia in den Kopf Joãozinhos versenkt worden war.

Damit endet die Verbindung des Körpers mit den Göttern.

Es ist eine umgekehrte Einweihungszeremonie.
A mãe anciã consente que Joãozinho da Gomeia não seja sepultado na Bahia, mas em Caxias.

O caixão é colocado sobre a mesa. Valentim, o Ogã Alabê, o mais velho dignatário do templo, que conhece os cantos de lansã e Oxóssi, começa o rito. Estão presentes alguns dos mais antigos lalorixás do Brasil.

Ebame Gifai,

Tião de Irajá,

Djalma de Lau,

Mãe Natalina,

Paulo de Oxossi.

Agora o morto dever ser retirado e o oxú.

O espírito do morto deve ser desprendido do corpo.

No fundo está uma cadeira coberta com um pano branco.

Nela está sentado o egum de Joãozinho da Gomeia e presencia a cerimônia.

Três carneiros são sacrificados. Tião de Iraja aproxima-se do

\section{Página 61}

cadáver no caixão e derrama um pouco de sangue sobre a cabeça do morto, lava-o em seguida com o abó, uma mistura de ervas que é utilizada nos ritos de iniciação.

Ele faz uma incisão na cabeça do morto e retira o oxu, o espírito dos deuses, que há 41 anos foi imergido pelo sacerdote Jubiaba na Bahia na cabeça de Joãozinho.

Com isso acaba a ligação do corpo com os deuses.

É uma cerimônia de iniciação ao contrário. 
Tião de Iraja ist der einzige, der diesen Ritus ausführen darf.

Niemand, der von Joãozinho eingeweiht worden ist, hätte das Recht, den Kopf des toten Priesters zu berühren.

\section{Sonntag, den 21. März:}

Die Beerdigung soll um 16 Uhr stattfinden.

Vorher treffen die Bischöfe Dom José Antonio da Silva und Dom Hugo da Silveira ein:

Wir stehen hier als katholische Geistliche und wollen einem Candomblétempel unsere Ehre erweisen.

Die brasilianische katholische Kirche möchte ihrem Schmerz über den Tod eines Candomblépriesters Ausdruck geben, der ein guter und reiner Mensch war. Wir möchten der ständig wachsenden Familie seiner Anhänger unser Beileid aussprechen. Er diente den Armen und erfülte die Gebote seiner afrikanischen Religion.

Der Sarg wurde unter Candomblégesängen zum Friedhof getragen. An der Pforte fand das Sirum Silé statt. Der Leichnam wird dem Iku, dem Friedhof, der Erde der Egum übergeben.

Es findet ein seltsamens Hin und Her statt, die Gläubigen bitten die Götter, das Ago, die Erlaubnis zum Betreten des Friedhofs zu erteilen.

Als der Sarg in die Grube gesenkt wird, blitzt es und Regen fällt.

Die Trauergäste heben die Arme auf und klatschen und stricken dem Himmel Blumen entgegen.

Sie rufen:

\section{Sarava! Jansa! Sarava!}

Wenn ein Sohn der Göttin lansa stirbt, den sie besonders liebt, schickt sie ein Gewitter.
Tião de Iraja é o único que tem permissão para realizar esse ritual.

Ninguém que foi iniciado por Joãozinho teria o direito de tocar a cabeça do sacerdote morto.

***

Domingo, 21 de março:

O enterro deve ocorrer às 16 horas.

Antes os bispos Dom José Antonio da Silva e Dom Hugo da Silveira se encontram:

Nós estamos aqui como clérigos católicos e queremos prestar nossa homenagem a um templo do candomblé.

A Igreja Católica brasileira gostaria de expressar sua dor pela morte de um sacerdote do candomblé, que também foi uma boa pessoa. Nós gostaríamos de exprimir nossas condolências à família de seus adeptos, que cresce constantemente. Ele serviu aos pobres e cumpriu os mandamentos de sua religião africana.

O caixão foi carregado para o cemitério sob cantos do candomblé. Na portaria aconteceu o sirum silé. O cadáver é entregue ao iku, ao cemitério, à terra dos eguns.

Ocorre um estranho ir e vir, os fiéis pedem aos deuses que concedam o agô, a permissão para pisar no cemitério.

Quando o caixão é baixado na cova, relampeja e a chuva cai.

Os acompanhantes do cortejo fúnebre levantam os braços e batem palmas e entrelaçam flores em direção ao céu.

Eles chamam:

Saravá! lansã! Saravá!

Quando um filho da deusa lansã morre, que ela ama em especial, ela manda uma tempestade. 
Jetzt beginnt das Axexe, da aber Joãozinho da Gomeia Tata de inkissu war, der am längsten amtierende Priester ganz Brasiliens, wird das Axexe nicht sieben Tage dauern, wie gewöhnlich, sonder ein ganzes Jahr.

\section{Seite 62}

Freitag, den 2. April:

A Tarde:

Präsident Medici gründet eine Informationsschule.

Die Schule soll Zivilpersonen und Militärs in der Verbreitung von Nachrichten und Konterinformationen ausbilden.

Geleitet wird die Schule von einem Brigadegeneral.

Dienstag, den 23. März:

Jornal do Brasil:

1000 Ausgehungerte besetzen Cupira und bleiben so lange, bis die Nahrungsmittelreserven des Paters Gomes erschöpft sind.

Mittwoch, den 24. März:

Jornal da Bahia:

Bewohner von Cidade de São João, die der Hunger irrsinnig werden liess, kämpfen mit den Geiern um das Aa seines Rindes.

Mittwoch, den 31. März:

A Tarde:

10000 Rinder verdursten in Sergipe.

Bauer wird verrückt und tötet seine Frau und das Vieh.
Agora começa o axexê, mas como Joãozinho da Gomeia foi Tata-de-inkice, o sacerdote em exercício por mais tempo em todo o Brasil, o axexê não vai durar sete dias, como de costume, mas um ano inteiro.

\section{Página 62}

Sexta-feira, 2 de abril:

A Tarde:

Presidente Médici funda uma escola de informação.

A escola deve formar pessoas civis e militares na divulgação de notícias e contrainformações.

A escola será dirigida por um general de brigada.

***

Terça-feira, 23 de março:

Jornal do Brasil:

1.000 famintos ocupam Cupira e permanecem até que tenham esgotado as reservas de alimento do padre Gomes.

***

Quarta-feira, 24 de março:

Jornal da Bahia:

Moradores da cidade de São João, que a fome deixou loucos, lutam com os abutres pela carniça de seu gado.

$\star * *$

Quarta-feira, 31 de março:

A Tarde:

10.000 bovinos morrem de sede em Sergipe.

Camponês fica louco e mata sua mulher e o gado.. 
In einigen Gemeinden sind die Strassen von Rinderleichen verstopft.

6000 Ausgehungerte verlassen Sergipe.

Freitag, den 2. April:

Jornal do Brasil:

700 Ausgehungerte bedrohen die Stadt Altinha.

Freitag, den 9. April:

Jornal da Bahia:

Hunderte von Ausgehungerten besetzen die Stadt Sera Talhade.

In Biritinga werden 50000 Rinder verdursten, wenn es nicht zu regnen beginnt.

***

Mittwoch, den 14. April:

Jornal do Brasil:

3000 Ausgehungerte besetzen Agua Preta. Ein 28jähriger Mann stirbt, ehe er etwas zu essen erhält.

\section{Seite 63}

Freitag, den 16. April:

A Tarde:

Präsident Medici reist in den Nordosten. In Recife wird er die Ehrenmedaille von Pernambuco in Empfang nehmen. Am Montag wird er den historischen Park von Guanarapes besichtigen und nach Brasilia zurückkehren.

Der Totengräber in Deodora wurde verrückt, er konnte seine sechs Söhne nicht mehr ernähren. Die Präfektur schuldete inm neun Monate den Lohn.
Em algumas comunidades, as ruas estão entupidas de cadáveres de gado.

6.000 famintos deixam Sergipe. ***

Sexta-feira, 2 de abril:

Jornal do Brasil:

700 famintos ameaçam a cidade de Altinha.

$* * *$

Sexta-feira, 9 de abril:

Jornal da Bahia:

Centenas de famintos ocupam a cidade de Sera Talhade.

Em Biritinga, 50.000 bovinos morrerão de sede se não começar a chover.

$* * *$

Quarta-feira, 14 de abril:

Jornal do Brasil:

3.000 famintos ocupam Agua Preta. Um homem de 28 anos morre antes de receber algo para comer.

\section{Página 63}

Sexta-feira, 16 de abril:

A Tarde:

Presidente Médici viaja ao Nordeste. Em Recife, ele receberá a medalha de honra de Pernambuco. Na segunda-feira ele visitará o parque histórico de Guanarapes e voltará para Brasilia.

O coveiro em Deodora ficou louco, ele não conseguiu mais alimentar seus seis filhos. A prefeitura devia a ele nove meses de salário. 
Donnerstag, den 22. April:

Jornal do Brasil:

1000 Ausgehungerte besetzen Palmares zum zweiten Mal und plündern Läden.

Dienstag, den 2. Mai:

Jornal do Brasil:

32 Prozent der nicht schulpflichtigen Kinder in Ceara leiden an Unterernährung 2. und 3. Grades. Nur 29,8 Prozent haben normales Gewicht.

Donnerstag, den 4. Mai:

Jornal do Brasil:

2000 arbeitslose Zuckerarbeiter drohen, die Stadt Cortez zu besetzen, wenn man ihnen keine Arbeit gibt.

Sonntag, den 7. Mai:

Jornal do Brasil:

6000 Zuckerarbeiter in Pernambuco erhielten drei Monate keinen Lohn.

Wir fahren im Bus zurück.

Der Bus braucht für 200 Kilometer 24 Stunden.

Vollgestopft mit Familien, die vom letzten Geld nach São Paulo wollen.

Kinder übergeben sich.

Eine Familie hat in Irece sechs Monate während der Dürre umsonst gearbeitet.
Quinta-feira, 22 de abril:

Jornal do Brasil:

1.000 famintos ocupam Palmares pela segunda vez e saqueiam lojas.

$* * *$

Terça-feira, 2 de maio:

Jornal do Brasil:

32 por cento das crianças sem obrigatoriedade escolar no Ceara sofrem de subnutrição de $2^{\circ}$ e $3^{\circ}$ graus. Somente 29,8 por cento têm peso normal.

***

Quinta-feira, 4 de maio:

Jornal do Brasil:

2.000 trabalhadores de engenho de açúcar desempregados ameaçam ocupar a cidade de Cortez, se não Ihe derem trabalho.

Domingo, 7 de maio:

Jornal do Brasil:

6.000 trabalhadores de engenho de açúcar em Pernambuco não receberam seus salários por três meses.

***

Nós viajamos de volta de ônibus.

O ônibus precisa de 24 horas para 200 quilômetros.

Abarrotado de famílias que, com seu ultimo dinheiro, querem ir para São Paulo.

Crianças vomitam.

Uma família trabalhou em Irece seis meses de graça durante a seca. 
Ein Greis, sein Sohn, dessen schwangere Frau, ein junger Mann, ein Junge. Die schwangere Frau trägt einen Säugling. Der Land-

\section{Seite 64}

besitzer stellte das Saatgut und die Geräte. Der Ertrag sollte geteilt werden. Die Familie arbeitete vom Hellwerden bis zur Dunkelheit wenigstens zwölf Stunden am Tag. Morgens etwas Kaffee. Mittags Bohnen. Abends Bohnen.

Die erste Ernte gelang. Das bracht 2000 cruzeiros - also 1000 Cruzeiros für fünf Arbeiter in sechs Monaten, bei zwölf Stunden Arbeit täglich - etwas mehr als 20 Mark im Monat für jeden.

Die zweite Ernte ist vertrocknet. Sie haben umsonst gearbeitet. Der Greis kann nicht lesen und schreiben. Der junge Mann hat als sechzehnjähriger zwei Monate in einem Alphabetisierungskurs gelernt, seinen Namen zu schreiben.

Sie stehen vor der Kneipe der Fernfahrer, wenn die Reifen des Busses gewechselt werden, und sehen den Essenden zu.

Sie wollen in São Paulo Arbeit finden.

An einer Haltestelle der Abschied eines Arbeiters, der auch nach São Paulo will:

Seine Frau krümmt sich vor Weinen. Sein Junge weint. Der Mann umarmt seinen Bruder lange. Er gibt der Mutter zum Abschied die Hand. Er sieht den Jungen kurz an. Seine Frau sieht er nicht an und steigt in den Bus.

Assis war Bandit.

Ein nackter Sarg. Kleckernde Ölfarbe: Francisco de Assis - Franz von Assisi.
Um ancião, seu filho e sua mulher grávida, um jovem homem, um menino. A mulher grávida carrega um nenê. O proprietário da terra-

\section{Página 64}

fornece as sementes e o equipamento. O lucro deveria ser dividido. A família trabalhava do clarear do dia ao escurecer - pelo menos 12 horas por dia. Pela manhã, um pouco de café. Ao meio-dia, feijão. À noite, feijão.

A primeira colheita deu certo. Isso trouxe 2.000 cruzeiros - ou seja, 1.000 cruzeiros para cinco trabalhadores em seis meses, com doze horas de trabalho diário - pouco mais que 20 marcos por mês para cada um.

A segunda colheita secou. Eles trabalharam por nada. $O$ ancião não sabe ler e escrever. $O$ jovem homem aprendeu, com dezesseis anos, por dois meses em um curso de alfabetização, a assinar seu nome.

Eles estão em pé, em frente ao bar dos motoristas de longo percurso, quando os pneus do ônibus são trocados, e observam as pessoas comendo.

Eles querem encontrar trabalho em São Paulo.

Numa parada, a despedida de um trabalhador que também quer ir para São Paulo:

Sua mulher curva-se de tanto chorar. Seu menino chora. O homem abraça seu irmão longamente. Ele dá a mão à mãe, como despedida. Ele olha o menino brevemente. Sua mulher, ele não olhou, e embarcou no ônibus.

Assis era bandido.

Um caixão despojado. Tinta a óleo escorrendo: Francisco de Assis - Franz von Assisi* . 
Auf dem Friehof Dom Bosco begleiten einige Neugierige das Begräbnis von Francisco de Assis L. Salles, 21, der seine Mutter kaum kannte und der seinen Vater hasste.

Daneben das übliche Foto:

Der Tote und seine Verfolger. Sie weisen auf die Einschusslöcher in der Leiche und sehen stolz und lächelnd in die Kamera. Lange Zeit versetzte Assis São Paulo in Angst und Schrecken. Jetzt können zig Raubüberfälle und Morde zu den Akten gelegt werden.

Er war ein Meter siebzig gross, rachitisch. Er starb bei einem Fluchtversuch.

45 Kugel im Körper.

Und wenn die Hunde seinen Kadaver auf meiner Schwelle fressen, ich würde inn nicht als meinen Sohn begraben.

Assis beschuldigte den Vater: Du hast meine Mutter umgebracht!

\section{Seite 65}

Assis wurde im Bundesstaat Rio Grande do Norte geboren. Er blieb dort bis zu seinem vierzehnten Lebensjahr.

Als Francisco drei Jahre alt war, starb die Mutter bei der Geburt einer Schwester.

Der Vater zog mit den Kindern nach São Paulo.

Assis fand Arbeit als Obstverkäufer und verdiente 60 Cruzeiros, 40 Mark, im Monat.

Mit 18 Jahren stahl er dem Vater das Geld für die Miete und floh.

Der Vater zeigte inn bei der Polizei an.

Er wurde in Campinas verhaftet.

Er wurde nach Hause zurückgebracht. Er hatte bereits acht Frauen.
No cemitério Dom Bosco, alguns curiosos acompanham o enterro de Francisco de Assis $L$. Salles, 21, que mal conheceu sua mãe e que odiava seu pai.

Ao lado, a foto habitual:

O morto e seus perseguidores. Eles apontam para os buracos de bala no cadáver e olham orgulhosos e sorridentes para a camera. Por um longo tempo, Assis espalhando medo e terror na cidade de São Paulo. Agora, inúmeros assaltos e assassinatos podem ser arquivados.

Ele tinha um metro e setenta, raquítico. Ele morreu em uma tentativa de fuga.

45 balas no corpo.

E se os cachorros comerem seu cadáver na minha soleira, eu não o enterraria como meu filho.

Assis culpava o pai: você matou minha mãe!

\section{Página 65}

Assis nasceu no Estado do Rio Grande do Norte. Ele ficou lá até seu décimo quarto ano de vida.

Quando Francisco tinha três anos, sua mãe morreu no parto de uma irmã.

O pai mudou-se com as crianças para São Paulo.

Assis encontrou trabalho como vendedor de frutas e ganhava 60 cruzeiros, 40 marcos, por mês.

Com 18 anos ele roubou de seu pai o dinheiro do aluguel e fugiu.

O pai o denunciou para a polícia.

Ele foi preso em Campinas.

Ele foi trazido de volta para casa. Ele já tinha oito mulheres. 
Er schlug seine Brüder und kam erst im Morgengrauen nach Hause.

Er floh zum zweiten Mal und nahm die Geliebte des Vaters, Genesia da Silva, mit.

Itaquera.

Vila Joanisa.

Jardim Miriam.

Santa Clara.

Cidade Ademar.

Cidade Dutra.

Parque São Lucas.

Rio Bonito.

Vila Missionaria.

Pedreira.

Die Legende von Franz von Assisi und seine Räuberbande.

Eine rote Tasche.

Zwei Revolver, einen 38er und einen 45er.

Maria das Dores, eine seiner Geliebten, gab der Polizei einen Tip.

Aber er entschlüpfte. Sie stürzte sich vom dritten Stock eines Hauses in São Paulo. Sie fürchtete seine Rache. Sie starb allein.

Claudia setzte alles daran, ihn wiederzusehen:

-Er hat das alles nicht getan!

Hundert Überfälle. Zehn Morde.

Als er durch die Avenida Santa Caterina ging, wurde er von einem Militärpolizisten entdeckt.

Francisco von Assisi schlief, als er eingezingelt wurde.

Am 3. März 1971 um 10 Uhr 50 wurde Franz von Assisi begraben.

\section{Seite 66}

Ele bateu nos seus irmãos e só veio para casa ao amanhecer.

Ele fugiu pela segunda vez e levou a amante do pai, Genesia da Silva, consigo.

Itaquera.

Vila Joanisa.

Jardim Miriam.

Santa Clara.

Cidade Ademar.

Cidade Dutra.

Parque São Lucas.

Rio Bonito.

Vila Missionaria.

Pedreira.

A lenda de Franz von Assisi e seu bando de salteadores.

Uma bolsa vermelha.

Dois revólveres, um 38 e um 45.

Maria das Dores, uma de suas amantes, deu à polícia uma pista.

Mas ele escapou. Ela se atirou do terceiro andar de uma casa em São Paulo. Ela temia sua vingança. Ela morreu sozinha.

Claudia fez de tudo para revê-lo:

-Ele não fez nada disso!

Cem assaltos. Dez assassinatos.

Quando ele ia pela Avenida Santa Caterina, ele foi descoberto por um policial militar.

Francisco von Assisi dormia quando ele foi cercado.

Em 3 de março de 1971 às 10 h50 Franz von Assisi foi enterrado.

Página 66 
Wie immer zündeten Unbekannte ein paar Kerzen an.

Gisèle Binon-Crossard, eine französiche Anthropologin, hat sich von Joãozinho da Gomeia in die Riten des »Candomblé Angola « einweihen lassen.

Joãozinho da Gomeia erzählte ihr sein Leben:

- Ich wurde in Inhambupe im Staate Bahia geboren.

- Mein Vater, meine Mutter waren Katholiken. Ich ging viel in die Kirche. Die Neffen des Pfarrers waren meine Schulkameraden.

- Ich habe bei der Messe ministriert und ein rotes Gewand angezogen, wie ein Chorknabe. Gut, ich hatte eine religiöse Tendenz.

Ich mochte den Candomblé nicht und verstand nicht viel davon.

Spiritisten gegenüber war ich abweisend.

Meine Grossmutter väterlicherseits war Afrikanerin. Sie lebt immer noch. Sie ist 109 Jahre alt. Sie wurde an der nigerianischen Küste, in Lagos, geboren und kam nach Brasilien, als sie 18, 19 Jahre alt war.

- Eines Nachts, als ich in einer Hängematte schlief, fühlte ich, wie die Hängematte zu schaukeln began. Ich wachte auf. Als ich die Augen öffnete, war es hell im Zimmer und vor mir sah ich eine Silhouette, eine Person, einen Indianer.

- Er war voller Federn und hatte eine Lanze in der Hand, Pfeile.

Ich erinnere mich nicht genau, denn ich empfand damals ein grosses Entsetzen und ich erinnere mich nicht genau an alles. Ich war damals 12, 13 Jahre alt.

- Er streckte einen sehr langen Arm aus und sagte mir: Morgen, wenn du hinausgehst, wirst du etwas glitzern sehen. Nimm es! Das wird dir Glück bringen.
Como sempre, alguns desconhecidos acenderam algumas velas.

Gisèle Binon-Crossard, uma antropóloga francesa, foi iniciada por Joãozinho da Gomeia nos ritos do "Candomblé de Angola".

Joãozinho da Gomeia contou a ela sua vida:

- Eu nasci em Inhambupe, no Estado da Bahia.

- Meu pai, minha mãe eram católicos. Eu ia muito à igreja. Os sobrinhos do padre eram meus colegas de escola.

- Eu acolitava na missa e vestia uma veste vermelha, como um menino de coro. Bom, eu tinha uma tendência religiosa

Eu não gostava do candomblé e não entendia nada disso.

Em relação aos espíritas, eu era reservado.

Minha avó por parte de pai era africana. Ela vive ainda. Ela tem 109 anos de idade. Ela nasceu na costa nigeriana, em Lagos, e veio para o Brasil quando tinha 18, 19 anos.

- Uma noite, quando eu dormia numa rede, eu senti como se a rede tivesse começado a balançar. Eu acordei. Quando eu abri os olhos, tudo estava claro no quarto e, diante de mim eu vi uma silhueta, uma pessoa, um índio.

- Ele estava cheio de penas e tinha uma lança na mão, flechas.

Eu não me lembro exatamente, pois eu senti, naquela época, um grande pavor e eu não me lembro exatamente de tudo. Eu tinha, naquela época, 12, 13 anos.

- Ele esticou um braço muito comprido e disse para mim: amanhã, quando você sair, você vai ver alguma coisa reluzir. Pegue-a! Isso te trará sorte. 
- Ich stiess einen Schrei aus und erschreckte meine Familie. Ich durfte den Rest der Nacht bei meinen Eltern schlafen. Ich verlor jeden Mut. Ich schlief nie wieder in einer Hängematte.

- Also am Morgen stand ich auf und ging in den Kolonialwarenladen. Ich arbeitete in einem Kolonialwarenladen. Und ich sah tatsächlich einen glitzernden Stein .. aber ich sammelte inn nicht auf und guckte nicht hin, denn ich hatte Angst.

- Von diesem Tag an hatte ich Angst, in dem Haus meiner Mutter zu schlafen. Ich schlief im Haus meiner Tante. Meine Tante schlief im ersten Zimmer, ich im zweiten.

Eines Nachts stand ich auf, denn ich musste urinieren. Ich legte mich wieder hin. Da hörte ich im Gang ein Geräusch, als rollte dort eine kleine Kinderkarre. Ich dachte, es sei der Onkel, der

\section{Seite 67}

immer sehr früh aufstand, um die Kühe zu melken. Die Tür ging auf, alles wurde hell. Es war keine Lampe. Die Quelle der Helligkeit konnte ich nicht sehen. Eine kleine Karre kam herein. Sie sah aus wie eine viereckige Kiste und war mit einem roten Tuch bedeckt. Sie hatte keine Räder. Ich konnte keine Räder entdecken. Ich hörte ein Geräusch, das dort herkam, wo die Räder sein mussten, aber ich sah keine Räder. Die kleine Kiste kam ans Bett heran. Ich war sehr entsetzt. Ich war wirklich wach, denn einige Minuten vorher war ich urinieren gewesen. Ich hatte mich gerade wieder hingelegt. Auf der Kiste standen zwei umgestülpte Gläser. Unter dem Glas war eine Puppe. Diese Puppen sprachen, aber ich verstand nicht, was sie sagten. Sie bewegten den Kopf, sie bewegten die Arme, sie bewegten ihre kleinen Beine .. und sie machten allerhand Sachen. Und ich blieb stumm. Ich konnte nicht schreien. Ich konnte
- Eu soltei um grito e assustei minha família. Me deixaram dormir o resto da noite com meus pais. Eu perdi toda a coragem. Eu nunca mais dormi numa rede.

- Então, de manhã eu me levantei e fui à loja de mantimentos. Eu trabalhava numa loja de mantimentos. E eu realmente vi uma pedra reluzente .. mas eu não a recolhi e não olhei para ela, pois eu tive medo.

- A partir desse dia, eu tive medo de dormir na casa da minha mãe. Eu dormia na casa da minha tia. Minha tia dormia no primeiro quarto, eu no segundo.

Uma noite, eu me levantei, pois eu tinha que urinar. Eu me deitei novamente. Aí eu ouvi no corredor um barulho, como se lá rolasse um

carrinho de bebê. Eu pensei que era meu tio, que

\section{Página 67}

sempre se levantava muito cedo, para ordenhar as vacas. A porta se abriu, tudo ficou claro. Não tinha nenhuma lamparina. A fonte da claridade, eu não podia ver. Um pequeno carro entrou. Ele parecia com uma caixa quadrada e estava coberto com um lenço vermelho. Ele não tinha rodas. Eu não pude descobrir nenhuma roda. Eu ouvi um barulho que vinha dali, onde as rodas deveriam estar, mas eu não vi nenhuma roda. $A$ pequena caixa chegou até a cama. Eu estava muito apavorado. Eu estava realmente acordado, pois alguns minutos antes, eu tinha ido urinar. Eu tinha acabado de me deitar novamente. Sobre a caixa estavam dois copos virados de cabeça para baixo. Sob o copo havia uma boneca. Essas bonecas falavam, mas eu não entendia 0 que elas diziam. Elas movimentavam a cabeça, elas movimentavam os braços, elas movimentavam suas pequenas pernas .. e elas faziam todo tipo de coisa. Eu não podia me levantar. Eu tinha que ficar ali e assistir 
nicht aufstehen. Ich musste dableiben und ihr Affentheater mit ansehen. Als ich endlich einen Schrei ausstossen konnte, kam meine Tante. Ich erzählte ihr, was vorgefallen war und sie nahm mich mit in ihr Zimmer.

Ich wollte nicht länger im Haus meiner Tante schlafen und ging zu meiner Grossmutter mütterlicherseits, die in derselben Strasse wohnte. Dort sah ich nie mehr das Geringste. Mir kam die Idee, dass ich von zu Hause weglaufen müsste ..

Ich floh um fünf Uhr morgens ..

Papa und mein Onkel setzten mich auf ein Pferd und brachten mich nach Hause zurück ..

- Ich setzte mir in den Kopf, dass ich noch einmal weglaufen müsste. Aber alle passten auf.

Ich zankte mich mit allen und sagte zu meiner Mutter, wenn sie mich nicht gehen liesse, würde ich beim Dorfrichter sagen, dass sie mich misshandelte. Ich benahm mich infernalisch.

Eines Tages gab sie nach und ich verliess Inhambupe.

Ich kam in Bahia an. Ein Verwandter brachte mich in einer Kolonialwarenhandlung unter. Ich verdiente 25 Cruzeiros. Ich arbeitete den ganzen Tag. Ich schlief auf drei Kisten mit Säcken, in denen Trockenfleisch gewesen war. Ich schlug mich durch. Ich lernte städtische Manieren, ordentlich zu reden, Konversation zu Machen. Ich fand eine Stelle, wo ich 30 Cruzeiros verdiente.

- Ich kriegte Kopfschmerzen. Solche Kopfschmerzen, dass mir die Courage fehlt, davon zu sprechen. Ich weiss nicht, ob sie von meinem Orixa kamen oder ob es eine richtige Krankheit war. Ich

\section{Seite 68}

àquelas macaquices. Quando eu finalmente consegui soltar um grito, minha tia veio. Eu contei a ela 0 que havia acontecido anteriormente e ela me levou consigo para seu quarto.

Eu não quis mais dormir na casa da minha tia e fui para a casa da minha avó por parte de mãe, que morava na mesma rua. Lá eu não vi mais nadinha. Me veio a ideia de que eu teria que fugir de casa ..

Eu fugi às cinco horas da manhã ..

Papai e meu tio me colocaram sobre um cavalo e

me levaram de volta para casa..

- Eu coloquei na cabeça que eu teria que fugir novamente. Mas todos estavam prestando atenção.

Eu briguei com todos e disse à minha mãe, se ela não me deixasse ir, eu diria ao juíz do lugarejo, que ela me maltratava. Eu me comportei de modo infernal.

Um dia ela cedeu e eu deixei Inhambupe.

Eu cheguei na Bahia. Um parente me alojou em uma mercearia. Eu ganhava 25 cruzeiros. Eu trabalhava o dia todo. Eu dormia sobre três caixas com sacos, em que estava carne seca. Eu me virei. Eu aprendi modos urbanos, a falar corretamente, a travar conversação. Eu encontrei um emprego, onde eu ganhava 30 cruzeiros.

- Eu começei a ter dores de cabeça. Tanta dor de cabeça, que me faltava a coragem de falar sobre ela. Eu não sei se elas vinham do meu orixá ou se era uma doença de verdade. Eu

\section{Página 68}


ging zu meiner Verwandten, zu allen Ärzten, je mehr Mittel ich nahm, desto schlechter ging es mir. Man riet meiner Verwandten, mich in einen jener Tempel mitzunehmen, die ich nicht kannte.

- Meine Verwandte nahm mich zu dem seligen Severiano mit, der unter dem Namen Jubiaba bekannt war.

- Er sagte, dass ich wiederkommen müsste, dass ich eingeweiht werden müsste. Das, was ich hätte, käme von meinem Orixa. Meine Verwandte müsste noch andere Sachen Machen. Sie tat, was er ihr sagte und mir ging es besser.

- Nach einem Monat kamen die Kopfschmerzen wieder. Ich ging wieder zu inm. Diesmal liess er mich nicht wieder nach Hause gehen. Er machte alles, was zu meiner Einweihung notwendig war.

Ich ging auch zu seinem Axexe. Nicht ganz bis zum Schluss, denn in der dritten Nacht gab es einen Aufstand gegen mich.

- Einige gingen so weit zu behaupten, ich sei schuld am Tod des Vaters Jubiaba.

Ich war gerade 19 und hatte selbst schon sechs Mädchen eingeweiht. Mein erster Candomblé war auf der Strasse nach Liberdade, Nummer 561.

- Eines Tages nahm der »Schwarze Stein« von mir Besitz.

Jetzt glaube ich, dass er es war, der mir erschienen ist, als ich 12, 13 war. Als er eintrat, waren alle Leute überrascht. Jetzt war ich eingeweiht, aber er war mir nie erschienen.

Während der kurzen Zeit, die er blieb, redete er mit den Leuten, hörte den einen an, den anderen und sagte, dass er nächsten Mittwoch wiederkommen würde. fui até a casa da minha parente, a todos os médicos, quanto mais medicamento eu tomava, pior eu ficava. Aconselharam minha parente a me levar a um templo que eu não conhecia.

- Minha parente me levou até o venerável Severiano, que era conhecido com o nome de Jubiaba.

- Ele disse que eu deveria retornar, que eu deveria ser iniciado. Isso, o que eu tinha, vinha do meu orixá. Minha parente teria que fazer outras coisas ainda. Ela fez o que ele lhe disse e eu fiquei melhor.

- Depois de um mês vieram as dores de cabeça novamente. Eu fui até ele de novo. Dessa vez ele não me deixou ir de volta para casa. Ele fez tudo o que era necessário para a minha iniciação.

Eu fui também ao seu axexê. Não até o final, pois na terceira noite houve uma revolta contra mim.

- Alguns chegaram a ponto de afirmar que eu era culpado da morte do pai Jubiaba.

Eu tinha acabado de fazer 19 anos e já tinha iniciado seis moças. Meu primeiro candomblé era na Rua da Liberdade, número 561.

- Um dia, "Pedra Preta" tomou posse de mim.

Agora eu acredito que era ele que me apareceu quando eu tinha 12, 13 anos. Quando ele entrou, todas as pessoas ficaram surpresas. Agora eu já estava iniciado, mas ele nunca tinha aparecido para mim.

Durante o curto tempo em que ele ficou, ele conversou com as pessoas, ouviu um e outro e disse que ele retornaria na quarta-feira seguinte. 
Als er gegangen war, sagte man mir, das sein Indianer gekommen sei, der "Schwarzer Stein « hiess, dass er sich um die Leute gekümmert hätte.

- Am nächsten Mittwoch kamen doppelt soviele Personen. Als ich wieder Luft kriegte, hatte ich das Haus voller Leute und wusste nicht, wohin damit. Ich zog nach Gomeia.

- Im Februar 1946 machte ich eine Reise nach Rio. Als ich ankam, verbreitete sich die Neuigkeit: Joãozinho da Gomeia ist in Rio! Der eine besuchte mich, der andre sagte mir gute Tag. Einer kam mich konsultieren, ein andrer bat mich um eine Arbeit. Ehe ich Luft holen konnte, waren neun Monate um. Ich fuhr weg. Als ich wiederkam, mietete ich ein Haus in Caxias.

\section{Seite 69}

Joãozinho da Gomeia konnte tanzen, tanzen wie keiner.

Tanzte er sich in das Allerheiligste des Priesters Jubiaba hinein, wie in das Wohlwollen des bahianischen Volkes, der Bürger von Salvador in Rio?

Grosse amerikanische Wagen parkten vor seinen Tempeln.

Er liebte den Fussball nicht.

1940 war er das letzte mal im Kino.

1945 heiratete er, doch die Ehe wurde, kinderlos, bald wieder getrennt.

Joãozinho erteilte brieflich religiöse Ratschläge in allen Lebenslagen.

$\mathrm{Er}$ hatte in einer Boulevardzeitung eine Kolumme.

Er wurde zum Prototyp des effeminierten Candomblegeistlichen.

Er soll den kräftigen Buben seiner Gunst auf der Strasse nachgelaufen sein und schrieb
Quando ele foi embora, disseram-me que um índio tinha vindo, que se chamava "Pedra Preta", que ele teria cuidado das pessoas.

- Na quarta-feira seguinte, veio o dobro de pessoas. Quando eu tomei fôlego de novo, eu tinha a casa cheia de gente e não sabia onde colocá-las. Eu me mudei para Gomeia.

- Em fevereiro de 1946, eu fiz uma viagem ao Rio. Quando eu cheguei, espalhou-se a novidade: Joãozinho da Gomeia está no Rio! Um me visitava, outro me dizia bom dia. Um vinha me consultar, outro me pedia um trabalho. Antes que eu pudesse respirar, passaram-se nove meses. Eu viajei. Quando eu retornei, aluguei uma casa em Caxias.

\section{Página 69}

Joãozinho da Gomeia sabia dançar, dançar como ninguém.

Será que ele se entranhou dançando no mais sagrado do sacerdote Jubiabá, como na boa vontade do povo baiano, dos cidadãos de Salvador no Rio?

Grandes carros americanos estacionavam diante de seus templos.

Ele não amava o futebol.

Em 1940 ele esteve no cinema pela última vez.

Em 1945 ele se casou, mas o casamento foi, sem filhos, logo dissolvido.

Joãozinho dava por carta conselhos religiosos para todas as situações da vida.

Ele tinha uma coluna num jornal de boulevard.

Ele se tornou protótipo dos religiosos efeminados do candomblé.

Ele teria corrido atrás de garotos de seu agrado na rua e escrito muito citadas cartas de amor a muitos homens pretos. 
vielzitierte Liebesbriefe an viele schwarze Männer.

1956 machte Joãozinho Schlagzeilen:

3800 Umbandageistliche wollten ihn aus dem Verein ausschliessen, weil er unter dem Namen Arlete als Transvestit beim Karnaval aufgetreten war.

Aber die Kaurimuscheln, die zur Entscheidung geworfen wurden, sprachen inn frei. Er wurde verwarnt und trat beim nächsten Karnaval wieder als Transvestit auf.

Er gehörte der Sambaschule Imperio Serrano an.

Der candombléfeindliche Diktator Getulio Vargas war sein Freund.

Präsident Kubitschek, der Gründer von Brasilia, liess Joãozinho da Gomeia zu geheimer Beratung in den Präsidentenpalast rufen. Joãozinho, der Abkömmling von afrikanischen Sklaven, der Stromer aus dem Nordosten, die verachtete, beneidete Tunte nützte und genoss diesen Augenblick. Mit barockem Hofstaat, unter Federn und Fächern, adrogyn, negroid, zog er zum Rendezvous mit der Staatsmacht.

Afrikanische Könige korrespondierte mit inm.

Eine weisse Studentin der Sorbonne liess sich von ihm einweihen.

In 41 Priesterjahren heiligte er 4777 Novizen.

Der Taxifahrer sagt:

- Joãozinho ist tot.

Er starb an demselben Tumor, wegen dem er vor 41 Jahren zum Candomblé gekommen ist.

\section{Seite 70}

Em 1956, Joãozinho foi manchete de primeira página de jornal:

3.800 religiosos da Umbanda quiseram excluí-lo da associação, porque ele se apresentou com o nome de Arlete como travesti no carnaval.

Mas as conchas kauri, que foram jogadas para a decisão, absolveram-no. Ele foi admoestado, mas no carnaval seguinte apresentou-se novamente como travesti.

Ele pertencia à Escola de Samba Imperio Serrano.

O ditador Getulio Vargas, inimigo do candomblé, era seu amigo.

Presidente Kubitschek, o fundador de Brasilia, mandou chamar Joãozinho da Gomeia para um aconselhamento secreto no palácio do presidente. Joãozinho, o descendente de escravos africanos, o vadio do nordeste, a bicha desprezada e invejada, aproveitou e desfrutou esse momento. Com uma côrte barroca, sob penas e leques, andrógino, negróide, ele partiu para um Rendezvous com o poder estatal.

Reis africanos se correspondiam com ele.

Uma estudante branca da Sorbonne se deixou iniciar por ele.

Em 41 anos de sacerdócio, ele consagrou 4.777 noviços.

O motorista de táxi diz:

- Joãozinho está morto.

Ele morreu do mesmo tumor, pelo qual ele há 41 anos veio para o candomblé.

Página 70 
Wenn er durch die Straßen von Bahia ging, stiessen sich die Leute an und sagten: Da geht Joãozinho da Gomeia.

Bispo de Paris mault vor sich hin, als ich inn frage, ob Joãozinho nun wirklich der König des Candomblé gewesen sei.

Offen Schlechtes über den Toten zu sagen, verbietet der Takt des Afrikaners und die Furcht vor der marodierenden Seele des Toten. Eine Wäscherin klagt Bispo de Paris ihre schlimmen Erfahrungen mit den Pais de Santo.

Sie leidet an nervösen Störungen und wollte eingeweiht werden.

Ein Priester verlangt von ihr 1800 Cruzeiros 1200 Mark.

- Ich bin Wäscherin und verdiene 80 Cruzeiros im Monat, wie soll ich das bezahlen?

Ein andrer Pai versichert ihr, sie habe Feuer im Bauch und verkauft ihr für 40 Cruzeiros ein Mittel, das inr nicht hilft.

Ein dritter sagt, sie sei von einem Toten besessen, und gibt ihr einen bitteren Kloss, an dem sie fast stirbt.

Schliesslich geht sie ins Krankenhaus, wo man sie mit Injektionen und Pillen behandelt.

Sie kann jetzt schlafen und hat keine Anfälle von Raserei mehr.

Aber sie sucht noch immer einen Pai de Santo, der sie einweiht, damit sie endgültig von ihrem Leiden befreit werde.

Am Freitag will Bispo de Paris weiter mit ihr darüber verhandeln.

Er sagt:

- Es gibt Leute, die bezahlen noch viel mehr als
Quando ele andava pelas ruas da Bahia, as pessoas se empurravam e diziam: lá vai Joãozinho da Gomeia.

Bispo de Paris amua quando eu lhe pergunto se Joãozinho era agora realmente 0 rei do candomblé.

Falar mal abertamente do morto, a prudência do africano proíbe e o temor da devastadadora alma do morto. Uma lavadeira queixa-se de Bispo de Paris por suas más experiências com os Pais de Santo*.

Ela sofre de distúrbios nervosos e queria ser iniciada.

Um sacerdote cobrou dela 1.800 cruzeiros -1 . 200 marcos.

- Eu sou lavadeira e ganho 80 cruzeiros por mês, como posso pagar isso?

Um outro Pai garante a ela que ela tem fogo no ventre e lhe vende por 40 cruzeiros um remédio que não adianta nada para ela.

Um terceiro diz que ela está possuída por um morto, e dá-Ihe um bolinho amargo, do qual ela quase morre.

Por fim, ela vai ao hospital, onde tratam-na com injeção e pílulas.

Ela consegue dormir agora e não tem mais ataques de furor.

Mas ela procura ainda um pai de santo* que a inicie, para que ela definitivamente seja libertada de seu sofrimento.

Na sexta-feira, Bispo de Paris quer continuar a negociar com ela sobre isso.

Ele diz:

- Há pessoas que pagam muito mais que 1.200 cruzeiros para serem iniciadas. Joãozinho da Gomeia recebia 5.000 cruzeiros por uma iniciação. Eu cobrei só os custos com os 
1200 Cruzeiros, um eingeweiht zu werden. Joãozinho da Gomeia hat 5000 Cruzeiros für eine Einweihung genommen. Ich verlangte nur die Unkosten für die Opfer und die Ernährung. Aber ich habe Pech. Zu mir kommen nur die Armen und ich muss innen auch noch die Opfertiere bezahlen. Deshalb habe ich noch nicht einmal mein Wohnhaus fertig bauen können.

Lazaro, der Fotograf:

-Vor vier Jahren wurde ein Mann obduziert; jeder Tote wird in Bahia obduziert. Man fand eine schwarze Masse im Magen und verdächtigte einen Pai de Santo des Giftmordes. Aber der Priester war der Freund eines Polizeikomissars und die Affaire wurde niedergeschlagen.

Die Sekte der Eguns, der Totenpriester auf der Insel Itaparica,

\section{Seite 71}

kennenzulernen, ist sehr schwer. Es ist auch gefährlich. Sie tragen bei den Festen, mit Kräuterabsuden getränkte Kleider. Wer diese Kleider berührt, bekommt lepraartige Geschwüre, die nur sehr schwer wieder heilen. Innen ist ein Gummibelag angebracht, um die Tänzer zu schützen.

Lazaro hält es für unmöglich, in der Stadt Bahia ein echtes Blutbad zu fotografieren.

Am Freitag, dem 7. April, schreibt Antonio Monteiro, ein bahianischer Priester, in der Zeitung »A Tarde «:

Niemand wird Priester, Pai de Santo, Babalorixa, ohne die verschiedenen Einweihungsgrade lawo, Ebame, Voudunce, Filho de Santo durchlaufen zu haben. Das kann 21 Jahre und mehr dauern. sacrifícios e a alimentação. Mas eu tenho azar. A mim vêm só os pobres e eu ainda tenho que pagar para eles os animais de sacrifício. Por isso ainda nem pude acabar de construir minha residência.

$* * *$

Lazaro, o fotógrafo:

-Há quatro anos, um homem foi autopsiado; todos os mortos na Bahia são autopsiados. Encontraram uma massa preta no estômago e suspeitaram de um pai de santo por assassinato por envenenamento. Mas o sacerdote era amigo de um delegado de polícia e o caso foi abafado.

Conhecer a seita dos eguns, os sacerdotes mortos, na llha Itaparica,

\section{Página 71}

é muito difícil. É também perigoso. Eles vestem nas festas roupas embebidas em decocções de ervas. Quem tocar essas roupas, contrai úlceras semelhantes à lepra, que só se curam com muita dificuldade.

Dentro foi entreposto um revestimento em borracha, para proteger os dançarinos.

Lazaro considera isso impossível, na cidade de Bahia, fotografar um verdadeiro banho de sangue.

***

Na sexta-feira, dia 7 de abril, Antonio Monteiro, um sacerdote baiano, escreveu no jornal "A Tarde":

Ninguém se torna sacerdote, pai de santo*, babalorixá, sem ter passado pelos diversos graus de iniciação iaô, ebomi, vodunce, filho de santo*. Isso pode durar 21 anos ou mais. 
Jeder in der afrobahianischen Welt weiss, dass Joãozinho nie geheiligt worden ist. Man hat inn weder geschoren noch bemalt. $\mathrm{Er}$ erhielt nie das »Deka«, er erhielt nie die Kalebasse von Ifa, um wahrsagen zu können. Er durfte sich nicht Olwo nennen, das heisst »Seher«.

In den Häusern der Ketou und der Ewe sah man ihn ungern, da er einen unmoralischen Einfluss auf die Gläubigen hatte. Seine ersten Versuche in Rio wurden von den Adepten der Umbanda nur ungern gesehen. Die Polizei nahm inn mehrere Male fest, weil er "Ebo «, böse Zauberfetische, an die Wegränder legte.

Als auf der Schwelle des Landwirtschaftsministeriums ein Ebo niedergelegt worden war, nahm die Polizei Joãozinho erneut fest.

\section{Er folgte seinem Schicksal.}

Er verdiente ein Vermögen und gab es mit Transvestiten und jungen Eingeweihten wieder aus.

Mittwoch, den 14. April:

Jornal do Brasil:

Aussenminister Scheel wird auf seiner Brasilienreise den Vertrag über die nukleare Zusammenarbeit zwischen Brasilien und der Bundesrepublik Deutschland bestätigen.

\section{Seite 72}

Sonntag, den 18. April:

Jornal do Brasil:

Aussenminister Scheel eröffnet in Brasilia die Bundesdeutsche Botschaft. Sie hat 15 Millionen Cruzeiros gekostet.

Industriegemunkel:
Todos no mundo afrobahiano sabe que Joãozinho nunca foi consagrado. Não o rasparam nem pintaram. Ele nunca recebeu o "deká", ele nunca recebeu a cabaça de Ifá para poder dizer a fortuna. Ele não tinha permissão de se denominar olwô, quer dizer, "vidente".

Nas casas dos Ketu e dos Ewe não o viam com boa vontade, pois ele tinha uma influência amoral sobre os fiéis. Suas primeiras tentativas no Rio foram somente vistas a contragosto pelos adeptos da Umbanda. A polícia o prendeu várias vezes, porque ele colocava "ebó", fetiche mágicos malignos, nas beiras dos caminhos.

Quando foi colocado um ebó na soleira do Ministério da Agricultura, a polícia prendeu Joãozinho novamente.

Ele seguiu seu destino.

Ele ganhou uma fortuna e gastou-a de novo com travestis e jovens iniciados.

Quarta-feira, 14 de abril:

Jornal do Brasil:

O ministro do exterior Scheel irá confirmar em sua viagem ao Brasil o acordo sobre a colaboração nuclear entre o Brasil e a República Federal da Alemanha.

\section{Página 72}

Domingo, 18 de abril:

Jornal do Brasil:

O Ministro do Exterior inaugurou em Brasilia a Embaixada Federal Alemã. Ela custou 15 milhões de cruzeiros.

Rumores da indústria: 
- Magirus Deutz muss entweder den südamerikanischen Markt aufgeben oder unerhört aufstocken.

- Magirus wird sich eventuell ganz auf Russland spezialisieren. Vielleicht ist das Gerücht aber auch nur ein Trick der deutschen Firma, um mehr Zuschüsse von der brasilianischen Regierung zu erhalten.

- Volkswagen wird von São Paulo aus den ganzen Kontinent beliefern.

Mittwoch, den 21. April:

Axexe für Joãozinho da Gomeia.

Für Joãozinho werden zwei Axexe veranstaltet, eines eine Woche lang in seinem Tempel in Caxias, ein zweites jetzt hier in seinem alten Tempel in Gomeia.

Es soll gegen acht Uhr abends beginnen.

An einigen Bäumen des Heiligtums brennen Kerzen.

Autos fahren vor. Viele kommen zu Fuss. Einige in teuren Anzügen.

Der Friseur, der auch bei der Totenmesse war, in Soie Sauvage.

Weiss ist de rigeur. Weiss ist die Farbe der Trauer.

Der riesige Versammlungsraum ist noch leer. In der Mitte, von einem Laken verdeckt wie eine Leiche, Kultgegenstände. Die Gemeinde klönt in den anderen Räumen des Heiligtums und trinkt Kaffee.

Über allen Türen und Fenstern sind ausgefranste Palmblätter angebracht.

Mãe Samba betritt den Versammlungsraum. Sie schiebt die neue Herrscherin über den Candomblé des Verstorbenen vor sich her. Die Götter haben ein achtjähriges Mädchen dazu erwählt - wohl
- Magirus Deutz deve abandonar o mercado sulamericano ou aumentar consideravelmente.

- Magirus irá provavelmente se especializar na Rússia. Talvez seja um boato, mas também um truque da firma alemã para receber mais subsídios do governo brasileiro.

- Volkswagen irá fornecer a partir de São Paulo para todo o continente.

$* * *$

Quarta-feira, 21 de abril:

Axexê para Joãozinho da Gomeia.

Para Joãozinho serão organizados dois axexês, um durante uma semana em seu templo em Caxias, um segundo agora, aqui em seu templo em Gomeia.

Deve começar às oito horas da noite.

Em algumas árvores do santuário ardem velas.

Carros passam em frente. Muitos vêm a pé. Alguns em ternos caros.

O cabeleireiro, que também estava na missa dos mortos, em Soie Sauvage.

Branco é de rigeur. Branco é a cor do luto.

A enorme sala de reunião está ainda vazia. No meio, coberto por um lençol como um cadáver, objetos do culto. A comunidade proseia nas outras salas do santuário e bebe café.

Em todas as portas e janelas foram colocadas folhas de palmeira desfiadas em franjas.

Mãe Samba* entra na sala de reunião. Ela empurra diante de si a nova soberana do candomblé do morto. Os deuses escolheram uma menina de oito anos para isso provavelmente 


\section{Seite 73}

um jahrzehntealte Missgunst unter den älteren Priesterinnen und Priestern zu besänftigen.

Da kleine Mädchen wird von den unwirschen Gläubigen hin und her gestupft wie eine unmündige Königin.

Etwa 300 Trauergäste treten ein. Jeder bekommt einen dünnen Palmstreifen um das Handgelenk gebunden. Mit dem weisssen Puder Pemba wird ein kleines Kreuz auf die Stirn und die Brust gezeichnet.

Mãe Samba tupft das Pemba auch auf die Lider und in den Nacken.

Das elektrische Licht wird ausgeknipst, drei Kerzen entzündet.

Mãe Samba beginnt die Gesänge des angolesichen Totenrituals.

Alle klatschen dreimal hohl in die Hände, treten klappernd mit den Füssen hin und her.

Das grosse weisse Tuch wird von den Kultgegenständen gehoben:

Neun Opfergerichte.

Zwei Vasen mit je vier Fahnen - rot, rosa, weiss, schwarz.

Auf dem Boden ein Häufchen Sand.

Drei Schüsseln, in denen halbe Kalebassen liegen.

Drei Tonkrüge.

Auf jede der Kalebassen wird mit zwei Stöckchen geklopft, die Tonvasen werden mit den Händen oder mit kleinen Palmenmatten geschlagen.

Auch Antonio setzt sich nun hin und beginnt den Rhythmus zu klappern, der anzügliche, proletarische Antonio als Totenmusikant für den reichen, angesehenen Joãozinho.

Vielleicht stand er in einem zarten Verhältnis oder in einem nicht allzu zarten Verhältnis zu
Página 73

para apaziguar o ressentimento entre as sacerdotisas e os sacerdotes mais velhos.

A pequena menina é empurrada levemente para lá e para cá, como uma rainha não emancipada.

Cerca de 300 convidados do funeral entram. Cada um recebe uma fina tira de palmeira para amarrar em torno do pulso. Com o pó branco de pemba é desenhada uma pequena cruz no testa e no peito.

Mãe Samba pontilha a pemba também nas pálpebras e no pescoço.

A luz elétrica é desligada, três velas acesas.

Mãe Samba começa os cantos do ritual angolês dos mortos.

Todos batem palmas ocas três vezes, pisam para lá e para cá, chocalhando com os pés.

O grande pano branco é erguido dos objetos de culto:

nove comidas de sacrifício.

Dois vasos com quatro bandeiras - vermelha, rosa, branca, preta.

No chão, um montinho de areia.

Três tigelas, nas quais estão meias cabaças.

Três potes de barro.

Em cada uma das cabaças dá-se umas pancadas com duas varetas, os vasos de barro são batidos com as mãos ou com pequenas esteiras de palmeira.

Até Antonio senta-se agora e começa a chocalhar o ritmo, o malicioso, proletário Antonio, como músico dos mortos para o rico, prestigiado Joãozinho.

Talvez tivesse estado em uma delicada relação - ou em uma não tão delicada relação com o 
dem Toten, und er sitzt heute nicht nur wegen rhythmischer Qualitäten hier.

Trommeln dürfen beim Axexe nicht geschlagen werden.

Knochengeräusche.

Spielte man früher mit Beinknochen auf Schädeln?

\section{Rippen auf Elefantenskeletten?}

Im deutschen Märchen spielt der Junge auf den Knöchelchen seines Bruders.

Jetzt das Opfer für Exu, der auch beim Totenfest günstig gestimmt werden muss. Zwei Mädchen tragen gelbe und weisses Mehl auf dem Rücken hinaus.

An der Tür stehen zwei Mädchen mit Palmwedeln, um den Toten den Eintritt zu verwehren.

\section{Seite 74}

Göttergesänge, zwei Reihen von singenden, tanzenden Töchtern des Toten bilden sich.

Mutter Samba ruft energischer und energischer die Götter an, mit fragenden und gebietenden Gesten.

Einzelne Frauen tanzen ausser der Reihe von den Schüsseln und Krügen.

Frauen und Männer nehmen Münzen auf, tanzen, geben die Münzen an andre weiter. Die Münzen werden abgelegt, etwas Sand verstreut, etwas Mehl.

Der Münzentanz geht stundenlang.

Charons Pfennige?

Mãe Samba verlässt den Raum. Sie wird von Würdenträgern und von den beiden Mädchen mit den Palmwedeln begleitet. Sie bleibt im Dunkeln an einigen Bäumen stehen, redet mit dem Toten:

Sie ruft: morto, e ele está sentado hoje aqui não somente por causa de suas qualidades rítmicas.

Os tambores não podem ser batidos no axexê.

Barulho de ossos.

Antigamente tocava-se com os ossos da perna nos crânios?

Costelas de esqueletos de elefante?

Nos contos de fada alemães, o menino brincava com os ossinhos de seu irmão.

Agora o sacrifício para Exu, que também tem que ser sintonizado favoravelmente na festa dos mortos. Duas moças carregam para fora farinha amarela e branca nas costas.

À porta estão duas moças com folhas de palmeira, para impeder a entrada do morto.

\section{Página 74}

Cantos dos deuses, duas fileiras de cantantes e dançantes filhas do morto se formam.

Mãe Samba invoca os deuses mais e mais energicamente, com gestos solicitantes e autoritários.

Mulheres dançam individualmente fora da fileira das tigelas e potes.

Mulheres e homens recolhem moedas, dançam, passam as moedas para frente a outros. As moedas são depositadas, espalhada um pouco de areia, um pouco de farinha.

A dança das moedas segue por horas.

Pfennigs de Caronte?

Mãe Samba* deixa a sala. Ela é acompanhada por dignitários e por ambas as moças com as folhas de palmeira. Ela fica em pé no escuro, encostada em algumas árvores, conversa com o morto:

Ela chama: 
- Joãozinho!

Weinen.

Aufschrein.

Schluchzen.

- Mein Kleiner!

- Morgen ist alles schon besser.

Ich dürfe nicht in der Zone zwischen den beiden Palmwedlerinnen stehen. Dort seien die Geister der Toten.

Mãe Samba sagt, ich solle wieder hineingehen; das dürfe ich nicht sehen.

Sie sagt es sehr zart, sehr liebevoll und traurig.

Einige Töchter werden von den Göttern besessen, stürzen aus dem Versammlungssaal nach draussen. Männer mit Ruten folgen innen nach und bringen die von den Göttern gerittenen »Pferde « wieder zurück.

Mutter Samba kümmert sich um jede einzelne, leiht ihr eigenes Brusttuch her, um innen den Schweiss abzutrocknen.

Die mondänen Gäste verziehen sich.

Die Tänze gehen weiter.

Schliesslich bleiben nur noch 100 Töchter, um ihrem verstorbenen geistlichen Vater das Geleit zu tanzen.

Einem weinenden Mann redet Mutter Samba zu.

Schlafende an den Wänden des Versammlungsraums.

In den anderen Räumen wird Kaffee serviert und das afrikani-

\section{Seite 75}

- Joãozinho!

Choro.

Clamor.

Soluço.

- Meu pequeno!

- Amanhã tudo vai ser melhor!

Eu não posso ficar em pé na zona entre as duas portadoras de folha de palmeira. Lá estariam os espíritos dos mortos.

Mãe Samba diz que eu devo entrar novamente; isso eu poderia ver.

Ela diz isso muito suavemente, muito carinhosamente e triste.

Algumas filhas são possuídas pelos deuses, se lançam da sala de reunião para fora. Homens com varas seguem-nas e trazem de volta os "cavalos" cavalgados pelos deuses.

Mãe Samba cuida de cada uma, empresta-Ihes seu próprio pano do peito para enxugar-lhes o suor.

Os convidados profanos dissipam-se.

As danças continuam.

Por fim, ficam somente 100 filhas para fazer o acompanhamento de seu pai spiritual dançando.

Mãe Samba alenta um homem em prantos.

Adormecidos encostados nas paredes da sala de reunião.

Nas outras salas é servido café e o prato africano

Página 75 
sche Gericht Caruru, verschiedene Gemüse, die mit getrockneten Krabben und Schinken zusammengekocht sind.

Gegen vier Uhr nachts sagt der immer noch auf seine Kalebasse einklappernde Antonio:

- Acabou!

- Es ist zu Ende!

Aber der Pai Valentino intoniert einen neuen Gesang. Nach einer halben Stunde sagt Pai Valentino:

- Acabou!

Die Palmfasern an den Handgelenken werden aufgeknüpft.

Die Kultgegenstände werden wieder zugedeckt.

Elektrisches Licht an.

In Taxis oder Privatwagen geht es nach Hause.

Bahia ist zu dieser Stunde wie ohne Leben.

Arme Schlafende in den Hauseingängen.

Psychosomatische Störungen nach dem Anhören des Schlagzeugs:

Wir stehen nachts auf und übergeben uns.

Durchfälle.

Allergische Reaktionen.

Unsere Denkfähigkeit verändert sich.

Dumpfheit.

Wir werden unaktiv, kritiklos, erinnerungslos.

Gegenüber dem Busbahnhof lebt eine Familie im Freien unter einer grossen Reklametafel.

»Calcigenol fürs gesunde Wachstum!« carurú, vários legumes, que são cozidos com camarão seco e presunto.

Por volta das quatro horas, diz Antonio, que ainda chacoalha a sua cabaça:

- Acabou!*

- Acabou!

Mas o Pai Valentino* entoa um novo canto. Depois de uma meia hora, Pai Valentino* diz:

- Acabou!

As fibras de palmeira nos pulsos são desatadas.

Os objetos do culto são cobertos novamente.

Luz elétrica ligada.

Em taxis ou carros particulares segue-se para casa.

Bahia está nessa hora como sem vida.

Pobres adormecidos nas entradas da casa

***

Distúrbios psicosomáticos depois de ouvir o tambor:

Nós nos levantamos de madrugada e vomitamos.

Diarreias.

Reações alérgicas.

Nossa capacidade de raciocínio se modifica.

Embotamento.

Nós ficamos inativos, acríticos, sem memória.

***

Em frente à estação rodoviária vive uma família ao ar livre, sob um grande painel de propaganda.

"Calcigenol para o crescimento saudável!" 
Die Familie hat sich ein paar Blechkanister, Pappe, Lumpen zusammengetragen.

Sie haust dort seit vierzehn Tagen.

Jeder kann sie sehen.

Die Arbeiter. Die Reisenden. Die Priester. Die Polizisten. Die Taxifahrer und inre Insassen.

Einige Steine dienen als Feuerstelle.

Die Frau kocht eine Mehlsuppe.

Der Mann hängt besoffen herum.

\section{Seite 76}

Die Kinder liegen mit vor Hunger rot verfärbten Haaren auf den Pappstücken.

Vor einem Monat hat sich die Familie in Pernambuco auf den Weg gemacht.

Ohne Geld.

Der Mann wollte im Staat Bahia Arbeit finden.

Als die Dürre ausbrach, versuchten sie es in der Grossstadt Salvador.

Vier Kinder sind unterwegs an Erschöpfung gestorben.

Die beiden letzten liegen im Sterben.

Niemand hilft innen.

Niemand sagt innen auch nur, dass die Hauptkirchen der Stadt von dem Bruchteil des Gelds, das sie an Bordellen und Absteigen verdienen, eine Armensuppe verteilen.

Der Mann erbettelt genug, um sich betrinken zu können.

Ers ist dabei, den Verstand zu verlieren.
A família recolheu alguns recipientes de lata, papelão, trapos.

Ela se aloja ali há catorze dias.

Todos podem vê-los.

Os trabalhadores. Os viajantes. Os padres. Os policiais. Os motoristas de táxi e seus ocupantes.

Algumas pedras servem como fogueira.

A mulher cozinha uma sopa de farinha.

O homem anda por ali, bêbado.

\section{Página 76}

As crianças estão deitadas nos pedaços de papelão, com os cabelos de uma descolaração avermelhada de fome.

Há um mês a família pôs o pé na estrada em Pernambuco.

Sem dinheiro.

O homem queria encontrar trabalho no Estado da Bahia.

Quando a seca eclodiu, eles tentaram a vida na grande cidade de Salvador.

Quatro crianças morreram no caminho, de exaustão.

As duas últimas estão morrendo.

Ninguém os ajuda.

Ninguém nem sequer lhes diz que as

principais igrejas da cidade, com a fração do dinheiro que elas ganham com os bordéis $e$ hoteizinhos baratos, distribui uma sopa aos pobres.

O homem mendiga o suficiente para poder se embebedar.

Ele está prestes a perder a razão. 
Sonntag, den 24. April:

Tribuna da Bahia:

Die ganze Welt soll wissen, wie der RotaryClub Brasilien sieht.

Der Rotary-Club von São Paulo will einen Bericht über Brasilien verbreiten, um der gezielten Verzerrung des brasilianischen Images im Ausland zu begegnen:

- Glauben Sie, diese Kampagne, die gegen unser Land und unsere Leute gerichtet ist, widerspricht unserer Philosophie und unserer Handlungsweise ..

Wir versichern, es ist nicht wahr, was gesagt wird; es ist nicht gerecht, was man uns vorwirft, es wird keinen good will zwischen den Völkern schaffen; es dient nur den Interessen der Umstürzler, der Korrupten und den Feinden der Demokratie.

Der Bericht spricht das Indianerproblem an und weist den Vorwurf des Genozids zurück.

Die Arbeit zeichnet die wirtschaftlichen Erfolge auf, u. a. das Ausgleichen des Defizits, das Wachstum des Bruttosozialproduktes - 1,6 Prozent 1963, 9 Prozent 1969.

200 Wörter sind Ackerbau und Viehzucht gewidmet.

\section{Seite 77}

Vor der Kirche São Francisco verteilen wohlhabende Damen an die Armen Brotstückchen aus Tüten.

Ein wohlgekleideter Mann sagt zu Leonore:

- Es ist unmenschlich, das Elend zu fotografieren.

Gründonnerstag.

Fusswaschung in der Kathedrale.

Zwölf unterwürfige Greise aus einem Asyl in unheimlichen, dunkelblauen Gewändern. Sie
Domingo, 24 de abril:

Tribuna da Bahia:

O mundo inteiro deve saber como o Rotary-Club vê o Brasil.

O Rotary-Club de São Paulo quer divulgar um relatório sobre o Brasil, para combater uma distorção dirigida da imagem brasileira no estrangeiro:

- Acredite o Sr., essa campanha, que é feita contra nosso país e nossa gente, contradiz nossa filosofia e nosso modo de agir ..

Nós asseguramos, não é verdade o que é dito; não é justo, do que nos acusam, isso não irá criar nenhum good will entre os povos; isso só serve aos interesses dos subversivos, dos corruptos e dos inimigos da democracia.

O relatório se refere ao problema dos índios e rejeita a acusação de genocídio.

O trabalho registra os sucessos econômicos, entre outros, a compensação do déficit, 0 crescimento do produto social bruto $-1,6$ por cento em 1963, 9 por cento em 1969.

200 palavras são dedicadas ao cultivo do campo e à criação de gado.

\section{Página 77}

$\mathrm{Na}$ frente da igreja São Francisco, damas abastadas distribuem, de sacos, pedaços de pão aos pobres.

Um homem bem vestido diz a Leonore:

- É desumano fotografar a miséria.

***

Quinta-feira Santa.

Lava-pés na catedral.

Doze anciãos submissos de um asilo em trajes estranhos, azul-escuros. Eles estão calçando 
haben neue, himmelblaue Plastiksandalen an. Sie sitzen erhöht auf einem Podest links neben dem Altar. Ihre himmelblauen Pyjamas gucken unter den dunkelblauen Büssergewändern raus.

Der Kardinal redet vor dem Mikrofon von seinen Brüdern. Seine Tiara zittert. Die dunkelblauen, greisen Brüder wischen sich nervös die geschrubbten Füsse. Sie ziehen gefältelte, schrillweisse Taschentücher aus den Gewändern und reiben sich zwischen ihren Sohlen und den Sohlen der Sandalen.

Der Kardinal nähert sich ihnen, umgeben von Ministranten und Priestern. Grosse Porzellanschüsseln werden vor die Greise hingestellt. Ein Ministrant hält ein Silbertablett mit riesigen Bonbons in rotem Glanzpapier.

Der Kardinal tut so, als wasche er die gewaschenen Füsse der Büsser in Demut.

Fernsehen und Blitzlicht.

Jeder der dunkelblauen Greise erhält einen Briefumschlag und einen Bonbon in rotem Glanzpapier.

Die Kinos sind überfüllt.

Im Cine Arte ein Stummfilm über die Passion Christi - der Gottessohn bewegt sich so schnell wie Charlie Chaplin.

Im Cine Pax eine italienische Passion aus den frühen 50er Jahren.

\section{Seite 78}

Karfreitag:

Prozessionsvorbereitung in Igreja do Carmo.

Neben dem Leichnam Christi stehen weibliche Polizisten Wache.

Hohe Militärs und der Governeur auf der Empore. sandálias de plástico novas, azul-celeste. Eles estão sentados elevados em um pedestal, à esquerda ao lado do altar. Seus pijamas azulclaros espiam para fora sob seus trajes azulescuros de penitentes.

O cardeal fala de seus irmãos ao microfone. Sua tiara treme. Os irmãos anciãos, azul-escuros, limpam nervosamente os pés esfregados. Eles tiram lenços de papel dobrados, de um branco estridente, de seus trajes e friccionam-se entre suas solas do pé e as solas das sandálias.

O cardeal aproxima-se deles, cercado por acólitos e sacerdotes. Grandes tigelas de porcelana são colocadas diante dos anciãos. Um acólito segura uma bandeja de prata com enormes balas em papel brilhante vermelho.

O cardeal faz como se lavasse os pés lavados dos penitentes em humildade.

Televisão e luzes de flash.

Cada um dos anciãos azul-escuros recebe um envelope e uma bala em papel brilhante vermelho.

$* * *$

Os cinemas estão lotados.

No Cine Arte, um filme mudo sobre a Paixão de Cristo - o filho de Deus se movimenta tão rápido como Charlie Chaplin.

No Cine Pax, uma paixão italiana do início dos anos 50 .

\section{Página 78}

Sexta-feira Santa:

Preparação da procissão na Igreja do Carmo.

Ao lado do corpo de Cristo estão guardas policiais femininas.

Altos militares e o governador na tribuna. 
Bruderschaften und Schwesternschaften der Afrikaner in eindrucksvollen Gewändern säumen die Strassen.

Zur Prozession trägt der Governeur huldvoll den Baldachin durch den Abfall des Prostituiertenviertels.

Die Kirche Rosario dos Pretos wurde von den Sklaven für die Afrikaner gebaut.

Die Kirche steht am Pelourinho, wo man die Aufsässigen an den Pranger stellte, wo man sie marterte und zu Tode peitschte.

Rosario dos Pretos ist selten geöffnet.

Heute hat man die Apsis schwarz ausgekleidet. Davor steht ein schwarzes, leeres Kreuz mit zwei schwarzen Leitern. Ein langes, schmales Laken hängt darüber.

Daneben eine überlebensgrosse Marienstatue.

$\mathrm{Zu}$ ihren Füssen ein brauner Holzsarg mit einem winzigen, blutübeströmten weissen Christus.

Afrikaner kommen und küssen die Totenlaken in dem Sarg.

Der Professor stellt uns dem berühmten $\mathrm{C}$. vor. C. ist niemand anderes als der Besitzer einer schwulen Absteige, die fünfmal so viel kostet wie die anderen.

C. meint, er müsse mich von irgendwoher kennen, und der Professor versucht immer wieder $\mathrm{C}$. von einem Irrtum zu überzeugen. C. erklärt auch, ich sei ein Bild der Keuschheit, der Heilige Joseph, und meine Frau eine der vielen Jungfrauen Maria, Oxum, eine der Göttinnen des Meeres.

Wir gehen an den vormittags noch unbenutzten Stundenkammern vorbei. Dazwischen eine Grotte mit den Wundern des
Irmandades masculinas e femininas dos africanos em trajes impressionantes alinham-se nas ruas.

Na procissão, o governador carrega benévolo o baldaquim através do lixo do bairro das prostitutas.

***

A Igreja Rosario dos Pretos foi construída pelos escravos para os africanos.

A igreja fica no Pelourinho, onde se colocavam os rebeldes no tronco, onde torturavam-nos e chicoteavam-nos até a morte.

Rosario dos Pretos está raramente aberta.

Hoje revestiu-se a ábside de preto. Na frente está uma cruz preta, vazia, com duas escadas pretas. Um lençol comprido, estreito, estendido sobre ela.

Ao lado, uma estátua de Maria, em tamanho sobrenatural.

A seus pés, um caixão de madeira marrom com um minúsculo Cristo branco, transbordando de sangue.

Africanos vêm e beijam os lençóis as mortalhas no caixão.

***

O professor nos apresenta o famoso $\mathrm{C}$.

C. não é ninguém mais que o proprietário de um hotelzinho homossexual barato, que custa cinco vezes mais que os outros.

C. diz que ele deveria me conhecer de algum lugar, e o professor tenta repetidamente convencer $\mathrm{C}$. de um erro. C. explica também que eu seria uma imagem da castidade, o São José, e minha mulher uma das diversas Virgens Marias, Oxum, uma das deusas do mar.

Nós passamos pelos quartos de aluguel por hora, ainda não utilizados pela manhã. Entre eles, uma gruta com os milagres de São Lázaro. 
Heiligen Lazarus. Anthropomorphe Gebilde aus Beton und Stein. Kleine Jahrmarktsstatuen der Heiligen Rochus und Lazarus, der Götter Omolu und Obaluae.

Im Keller Barockzement - ein Altar für den Heiligen Georg.

Jetzt verstehe ich, warum C. seinen Kunden so horrende Tarife abverlangt. Er will damit die Betonaltäre weiterbringen.

\section{Seite 79}

Ein Zimmer für die Meergöttin Jemanha. Wir müssen uns auf den Boden legen, um ihre Gestalt in dem verästelten Gebilde aus Tropfzement zu erkennen - Jungfrau Maria und Nixe.

Eine Falltür führt in den Raum Exus, des Teufels. Um alle Gefahren von uns abzuwenden, geht $\mathrm{C}$. als erster hinunter und führt uns bei dem Gott der Kreuzwege und der Pforten ein.

C. redet ununterbrochen. Es ist das Reden der Schamanen, der Transvestiten. Dieser Redeschwall mit spezifischen, rhetorischen Figuren ist bei allen gleich: Bei Testanière in der Provence, bei Cartacalo/la in der Lockstedter Schrebergartenkolonie, bei Quirinus Kuhlmann und bei Mohammed allen gemeinsam dieser Rausch nicht mehr abreissender, göttlicher Wörter. Sicher war es auch bei dem Heiligen Hieronymus schwer, wieder aus der Tür zu kommen.

Zwanzig Mark für Kerzen nimmt C. gern.

$* * *$

\section{Regen:}

Ich sehe nichts.

Der Strom fällt aus.

Ich rieche kaum etwas in der Dunkelheit.

An Geschmack denke ich nicht, auch nicht an Berührungen.
Esculturas antropomórficas de concreto e pedra. Pequenas estátuas da feira anual, de São Roque e São Lázaro, dos deuses Omulu e Obaluaê.

No porão, cimento barroco - um altar para o São Jorge.

Agora eu entendo, porque C. cobra de seus clients tarifas tão horrendas. Ele quer, com isso, levar adiante os altares de concreto.

\section{Página 79}

Um quarto para a deusa do mar lemanjá. Nós temos que nos deitar no chão, para distinguir sua forma na ramificada imagem de cimento pingado - Virgem Maria e nixe.

Uma porta horizontal no quarto de Exu, o diabo. Para afastar todos os perigos de nós, C. vai primeiro para baixo e nos introduz ao deus das encruzilhadas e dos portais.

C. fala ininterruptamente. É a fala dos xamãs, dos travestis. Essa torrente de palavras com figuras específicas, retóricas, é igual em todos: em Testanière na Provence, em Cartacalo/la na colônia de Jardins Schreber em Lockstedt, em Quirinus Kuhlmann e em Mohammed - a todos é comum esse êxtase de infindáveis, divinas palavras. Com certeza, com São Jerônimo também era difícil sair pela porta.

Vinte marcos para velas, C. pega com prazer. ***

Chuva:

Eu não vejo nada.

A energia elétrica falta.

Eu mal posso cheirar algo no escuro.

Eu não penso em paladar, em toques também não. 
Durch mein überdimensional ausgedehntes Gehör besteht die Welt nur aus Tropfen und Fröschen.

Fröschen wie Esel.

Fröschen wie Vögel.

Fröschen wie Michael.

Fröschen wie Hammer und Meissel.

Fröschen wie »Hilfe!«.

Fröschen wie Presslufthämmer.

Fröschen wie Kreissägen.

Fröschen wie Wiener Sängerknaben.

Fröschen wie Autos.

Fröschen wie Frösche.

Unken unken.

Ochsenfrösche.

Unken Frösche?

Fröscheunken unken.

Unkenfrösche fröschen.

Fröschefrösche fröschen.

\section{Seite 80}

Was geschieht, wenn es 24 Stunden in einer Favela regnet:

Die Lehmhäuser werden weich und sinken zusammen.

Alles nass:

Die Decken, die Kleidung, die Haare, das Mehl, die Bohnen, die Dochte, die Streichhölzer, die Holzkohle.

Die Dosen mit Milchpulver fangen an zu rosten.

Amöben und Lungenschnecken werden in das Brunnenwasser gespült.
Através da minha audição ultradimensional expandida, o mundo consiste de gotas e rãs.

Rãs como burros.

Rãs como pássaros.

Rãs como Michael.

Rãs como martelo e cinzel.

Rãs como "Socorro!"

Rãs como martelos pneumáticos.

Rãs como serras circulares.

Rãs como os meninos cantores de Viena.

Rãs como carros.

Rãs como rãs.

Bombinas ominam.

Rãs-touro.

Ominam rãs?

Rãsbombinas ominam.

Bombinasrãs raneiam.

Rãsrãs raneiam.

\section{Página 80}

O que acontece quando chove 24 horas em uma favela:

As casas de pau-a-pique ficam moles e vão abaixo.

Tudo molhado:

As cobertas, a roupa, os cabelos, a farinha, o feijão, os pavios, os fósforos, o carvão vegetal.

As latas com leite em pó começam a enferrujar.

Amebas e moluscos pulmonados escorrem para a água do poço. 
Einige hundert Meter von dem Candomblé des Joãozinho da Gomeia, wo die Nächte durch für den Toten im Trockenen getrommelt wird, sind Häuser abgerutscht.

Die Leichen einer Familie liegen auf dem Asphalt.

Sie werden gerade zugedeckt zum Abtransport.

Als die Arbeiter sehen, dass Leonore einen Fotoapparat hat, decken sie die Leichen noch einmal auf, legen sie dichter zusammen und heben die toten Kinder an, damit sie auch dem Foto erscheinen.

Dienstag, den 27. April:

Jornal da Bahia: Diluvium in der Stadt!

Tribuna da Bahia: 53 Verletzte. 18 Tote. 30 eingestürzte Häuser.

A Tarde: Ein leichter Anstieg der Kinderlähmung.

Jornal da Bahia: Die Wetterstation erklärt, die starken Regenfälle seien durch eine Kaltlufttront aus dem Süden bedingt.

Bis 21 Uhr gestern fielen 216,8mm Regen; der stärkste Regenfall in den letzten vier Jahren.

Tribuna da Bahia: Herr Präfekt, ein Tag Regen und die ganze Stadt steht unter Wasser!

- Heute wurden in Salvador die grössten Regenfälle seit 14 Jahren gemessen.

- Glauben Sie, damit könnte man den Zustand erklären, in dem sich die Stadt befindet?

- Ich bin nicht dafür verantwortlich. Dieser Zustand dauert bereits 400 Jahre.

A Tarde: Der nordamerikanische Botschafter ist in Bahia eingetroffen und will den Fortschritt in der Stadt feststellen.
A algumas centenas de metros do candomblé de Joãozinha da Gomeia, onde noites inteiras se toca tambor para o morto no seco, casas deslizaram.

Os cadáveres de uma família jazem sobre o asfalto.

Eles são cobertos para o transporte de remoção.

Quando os trabalhadores veem que Leonore tem uma camera fotográfica, eles descobrem os cadáveres novamente, colocam-nos mais juntos e levantam as crianças mortas, para que elas também apareçam na foto.

$* * *$

Terça-feira, 27 de abril:

Jornal da Bahia: dilúvio na cidade!

Tribuna da Bahia: 53 feridos. 18 mortos. 30 casas desabadas.

A Tarde: um leve aumento da paralisia infantil.

Jornal da Bahia: a estação de tempo explica que as fortes quedas de chuva seriam condicionadas pela frente de ar frio do sul.

Até às 21 horas caíram 216,8 mm de chuva; a mais forte queda de chuva nos últimos quatro anos.

Tribuna da Bahia: Senhor Prefeito, um dia de chuva e a toda a cidade está debaixo d'água!

- Hoje foram medidas em Salvador as maiores quedas de chuva em 14 anos.

- O Senhor acha que com isso se pode explicar o estado em que a cidade se encontra?

- Eu não sou responsável por isso. Esse estado dura já 400 anos.

A Tarde: o embaixador norte-americano chegou à Bahia e quer verificar o progresso na cidade. 


\section{Seite 81}

Im Palacio da Aclamaçao, dem Beifallspalast des Governeurs, verteilt man Essen an die Obdachlosen. Das Packpapier füllt den Garten an; es sieht aus, als habe sich das vornehme Gebäude erbrochen.

Mittwoch, den 30. April:

Jornal da Bahia: 100 Tote.

Tribuna da Bahia: Notzustand für dreissig Tage ausgerufen.

Jornal da Bahia: Millionenschäden.

Tribuna da Bahia: Erdrutsch.

A Tarde: Grösste Tragödie in der Geschichte der Stadt.

Tribuna da Bahia: Wasser fehlt in der ganzen Stadt. Jegliches Brunnenwasser vor dem Trinken abkochen.

Jornal da Bahia: Poliomyelitis unter Kontrolle.

Tribuna da Bahia: 140 Tote. 2000 Verletzte. 3 000 Obdachlose.

Tribuna da Bahia: Playtime ..

- Einer der feuchsten und regenreichsten Nachmittage ..

- Um so wärmer und gastfreundlicher ..

- Fröhliche und spontane, wenn auch untadelige Gastfreundschaft der Judy Watson

- Sympathie der geehrten Bostschaftersgattin Suzanne Rountree ..

- Lag über dem Haus der Ton der Rosen ..

- Porzellantassen und zwei Silbertabletts ..

- Tee oder Schokolade ..

- Garçons ..

\section{Página 81}

No Palacio da Aclamaçao, o Palácio da Ovação do Governador, distribui-se comida aos sem teto. O papel de embrulho enche o jardim; parece que o prédio elegante vomitou.

Q

Quarta-feira, 30 de abril:

Jornal da Bahia: 100 mortos.

Tribuna da Bahia: decretado estado de emergência por trinta dias.

Jornal da Bahia: prejuízos de milhões.

Tribuna da Bahia: deslizamento de terra.

A Tarde: maior tragédia na história da cidade.

Tribuna da Bahia: falta água em toda a cidade. Ferver toda água de poço antes de beber.

Jornal da Bahia: poliomielite sob controle.

Tribuna da Bahia: 140 mortos. 2. 000 feridos. 3. 000 sem teto.

Tribuna da Bahia: Playtime ..

- Uma das tardes mais úmidas e ricas de chuva - Ainda mais quente e mais hospitaleiro ..

- Alegre e espontânea, ainda que impecável hospitalidade da Judy Watson ..

- Simpatia da prezada esposa do embaixador, Suzanne Rountree ..

- Pairava sobre a casa o tom das rosas ..

- Xícaras de porcelana e duas bandejas de prata

- Chá ou chocolate ..

- Garçons .. 
- Verschiedene Tische von österreichischen Stühlen umgeben ..

- Anziehend und schlank, von gutmütigen und geprägten Zügen ..

- Kanariengelbe Seide ..

- Chanel ..

- Im kleinen Schwarzen ..

- Chanel ..

- Shantung ..

- Midi ..

- Aufgedruckte Pastellfarben ..

- Tablett mit tausend leckeren Sachen ..

- Weitere Rosen in vielfarbenen Tuffs ..

- Erfrischungen gereicht ..

- Für Nichtraucher Konfekt ..

\section{Seite 82}

- Garçons ..

Der Empfang in der Residenz des amerikanischen Konsuls für die Gattin des Botschafters der USA.

Tribuna da Bahia: Die Amerikaner gestehen: Wir foltern Zivilpersonen in Vietnam.

Evakuierte in der Baixa dos Sapateiros:

- In unsere Wohnungen hat es immer hereingeregnet. Die ganze Einrichtung ist hin. Wir übernachten bei Freunden, mit 30, 40 anderen Obdachlosen.

Anderen kampieren auf der Strasse in einem geschützten Winkel.

- Der Staat kann uns doch nicht helfen.

- Es gibt 5000 Obdachlose. Soviel Geld hat doch der Staat gar nicht.
- Várias mesas rodeadas por cadeiras austríacas ..

- Atraente e magra, de traços generosos e marcados ..

- Seda amarelo-canário ..

- Chanel ..

- No pretinho clássico ..

- Chanel ..

- Shantung ..

- Midi ..

- Cores pastéis impressas ..

- Bandejas com mil coisas saborosas ..

- Mais rosas em tufos multicoloridos ..

- Refrescos servidos..

- Para não fumantes, bonbons ..

\section{Página 82}

- Garçons ..

A recepção na residência oficial do cônsul americano para a esposa do embaixador dos EUA.

Tribuna da Bahia: os americanos confessam: nós torturamos civis no Vietnã.

$* * *$

Evacuados na Baixa dos Sapateiros:

- Em nosso apartamento sempre choveu. Toda a mobília está perdida. Nós pernoitamos em casa de amigos, com 30, 40 outros sem teto.

Outros acampam na rua, em um canto protegido.

- Mas o estado não pode nos ajudar.

- Há 5.000 sem teto. Tanto dinheiro, o estado não tem de jeito nenhum. 
Eine 65jährige besitzt nur noch das, was sie auf dem Leib hat.

- Ich habe keine Kinder, keinen Mann, keine Verwandte.

Eine 70jährige sitzt stumm auf einer Insel im Wasser und versucht, verjährte Zeitschriften zu trocknen.

President Medici erhöht in seiner Ansprache an die Arbeiter zum ersten Mai die Mindestlöhne auf 151,20 und 225,60 Cruzeiros je nach Region.

Der Mindestlohn wird erwachsenen Arbeitern für 30 Arbeitstage, 240 Arbeitsstunden im Monat, gezahlt.

Im letzten Jahr sind die Lebenskosten um 20 Prozent gestiegen.

Der Mindestlohn von Mai 1971 hätte im Mai 1970 einen gerigen Fortschritt bedeutet. Jetzt bleibt die Erhöhung bereits hinter der Verteuerung der Grundnahrungsmittel zurück.

Die Verelendung wird für etwa 80 Prozent der Bevölkerung also bis Mai 1972, bis zur nächsten Erhöhung, noch zunehmen.

Welcher Arbeitgeber ist bereit, den Mindestlohn zu zahlen?

Wer hält sich an die täglichen acht Stunden Arbeitszeit?

Was erhalten Kinder?

\section{Seite 83}

Dienstag, den 4. Mai:

A Tarde:

Antonio Monteiro berichtet vom letzten Tag des Axexe für Joãozinho da Gomeia.

Das Axexe beginnt in der Nacht des 21. April und endet am 28. Mit einer Missa Solemnis,
Uma mulher de 65 anos possui somente a roupa do corpo.

- Eu não tenho nenhum filho, nenhum marido, nenhum parente.

Uma mulher de 70 anos está sentada muda numa ilha na água e tenta secar revistas velhas.

Presidente Medici aumenta, em seu discurso aos trabalhadores no primeiro de maio, o salário mínimo para 151,20 e 225,60, de acordo com a região.

O salário mínimo é pago a trabalhadores adultos por 30 dias de trabalho, 240 horas de trabalho por mês.

No ano passado, o custo de vida subiu 20 por cento.

O salário mínimo de maio de 1971 teria significado em maio de 1970 um pequeno progresso. Agora o aumento já fica atrás do encarecimento dos gêneros alimentícios básicos.

A pauperização irá aumentar ainda mais para cerca de 80 por cento da população, portanto, até maio de 1972, até o próximo aumento.

Qual empregador está disposto a pagar o salário mínimo?

Quem se atém às oito horas diárias do horário de trabalho?

O que recebem as crianças?

\section{Página 83}

Terça-feira, 4 de maio:

A Tarde:

Antonio Monteiro relata sobre o ultimo dia do axexê para Joãozinho da Gomeia.

O axexê começa na madrugada do 21 de abril e termina no dia 28. Com uma Missa Solemnis, 
"Eça «, in der Kirche des Pelourinho, die von Negern erbaut worden ist.

Die Besucher des Axexe gehen zu Mãe Samba, Sambadiamungo, und werden mit einem weissen Gipspuder, Pemba, betupft. Sie schliessen die Augen und Mãe Samba zeichnet ein kleines Kreuz auf die Stirn, auf jeden Augenlid, auf die Brust.

Jetzt ist der Besucher gereinigt und er braucht die Toten nicht mehr zu fürchten. Vier Oga heben nun ein Laken von den heiligen Gegenständen und dem Schlagzeug.

Sechs Alabas, Schlagzeuger, setzen sich dahinter auf eine sehr niedrige Bank.

Dem Mann von der Strasse, Exu, dem Götterboten wird geopfert:

Zwei Teller mit Maismehl, ein Krug mit Wasser und eine brennende Kerze werden inm geweiht.

Eine Tochter der Göttin lansas bringt es nach draussen ins heilige Gelände.

Als sie zurück ist, giesst ein Oga Palmöl, Honig, Wein über das Schlagzeug - über drei umgekehrte Kalebassen und drei Tonkrüge. Alle diese Gegenstände sind neu.

Die Kalebassen werden mit kleinen Holzstöcken, Akidavi, geschlagen, die Krüge mit der Hand und mit kleinen geflochtenen Fächern.

Die Schlagzeuger lösen sich ab. Es sind insgesamt 18. Je sechs.

Die Gesänge sind von der Nation Angola.

Rechts steht Mãe Samba, links Sandra, beide beginnen die Trauertänze und die Töchter folgen.

Die Kultgegenstände liegen zu einem Dreieck geordnet. Sie sind von zwei grossen Marios, geflochtenen Palmblättern, umgeben.

Palmblätter wehren die Toten ab.
"Eça", na igreja do Pelourinho, que foi contruída por negros.

Os visitantes do axexê vão até Mãe Samba, Sambadiamungo, e aplica-se-lhes levemente um pó branco de giz, Pemba. Eles fecham os olhos e Mãe Samba desenha uma pequena cruz na testa, em cada pálpebra e no peito.

Agora o visitante está limpo e ele não precisa mais temer os mortos. Quatro ogãs levantam agora o lençol dos objetos sagrados e do tambor.

Seis alabás, tocadores de tambor, sentam-se atrás em um banco muito baixo.

Ao homem da rua, Exu, o mensageiro dos deuses, oferece-se um sacrifício:

Dois pratos de farinha de milho, uma caneca com água e uma vela acesa são consagrados a ele.

Uma filha da deusa lansã leva-o para fora, ao terreno sagrado.

Quando ela volta, um ogã derrama óleo de palmeira, mel, vinho sobre o tambor - sobre três cabaças viradas de cabeça para baixo e três vasos de barro. Todos esses objetos são novos.

As cabaças são batidas com pequenas varetas de madeira, akidavi, os vasos com a mão e com pequenos leques trançados.

Os tocadores de tambor revezam-se. São 18 no total. Cada vez seis.

Os cantos são da nação Angola.

À direita estã Mãe Samba, em pé, à esquerda, Sandra, ambas começam as danças fúnebres e as filhas seguem.

Os objetos de culto estão ordenados em forma de triângulo. Eles estão cercados por dois grandes Marios, folhas de palmeira trançadas.

Folhas de palmeira repelem os mortos. 
Neun Teller mit Opfergaben für die Egum stehen bereit - die Mahlzeit der Toten.

Von elf bis Mitternacht wird der Tote gerufen.

Von Mitternacht bis ein Uhr werden die Götter angesungen; man beginnt mit lansa. Sie hat als einzige Macht über die Toten. Das

\section{Seite 84}

Gebet Angorossi, das Gebet um Vergebung, wird vom Babalorixa Valentim gesungen.

Schreie:

-Rirro! Uo!

Der Fetisch der Göttin lansa, das Alukare, und ein Mettalschwert werden beim Tanzen geschwungen. Das Alukare ist das Schwanzbüschel eines Opferstiers.

An der Eingangstür steht ein grosser Krug mit dem Einweihungsgetränk Abó. Die Gläubigen benetzen ihre Finger damit, um vor den Toten geschützt zu werden.

Gegen drei Uhr morgens beginnt der wichtigste Teil des Axexe.

Es wird jetzt in der Nation Ketou gesungen:

- Axexe Lonan.

Es wird geschrien:

- Rirro! Rio! Uo!

Währenddessen bereitet man das Carrego der Egum, die Last der Toten, vor.

Alle Gegenstände aus dem Tempel, die während des Axexe gebraucht worden sind, und die Kleider des Toten werden an einem von den Göttern bezeichneten Ort im Wald oder am Strand niederlegt.

Donnerstag, den 29. April:
Nove pratos com oferendas para os Egum estão prontos - a refeição dos mortos.

Das onze à meia noite o morto é chamado.

Da meia-noite à uma, canta-se para os deuses; inicia-se com lansã. Ela é a única que tem poder sobre os mortos. A

\section{Página 84}

Oração Angorossi, a oração do perdão, é cantada pelo Babalorixá Valentim.

Gritos:

-Rirro! Uo!

O fetiche da deusa lansã, o aluquerê e uma espada de metal, são balançados na dança. $O$ aluquerê é o tufo do rabo de um animal de sacrifício.

Na porta de entrada está um grande jarro com a bebida da consagração, abó. Os fiéis umedecem seus dedos nela, para serem protegidos dos mortos.

Por volta de três horas começa a parte mais importante do axexê.

Agora canta-se para a nação Ketu:

- Axexê Lonan.

Grita-se:

- Rirro! Rio! Uo!

Enquanto isso, prepara-se o Carrego dos Eguns, a carga dos mortos.

Todos os objetos do templo que foram usados durante o axexê e as roupas do morto são depositados em um lugar determinado pelos deuses, na floresta ou na praia.

Quinta-feira, 29 de abril: 
A Tarde: 104 Tote. 1400 Häuser durch Erdrutsch und Regen zerstört. 7000 Obdachlose.

Tribuna da Bahia: $534 \mathrm{~mm}$ Regen, die grösste Menge seit 1903.

A Tarde: Typhusgefahr.

Die Obdachlosen, die erst im Mercado de Curtume untergebracht waren, sind in die Essobaracken transportiert worden.

Unter Polizeibewachung.

Drei Polizisten stehen am Eingang des Geländes.

Fünf Polizisten am Eingang zu der hallenartigen Baracke.

Zementfussboden. Schlamm. Im Schlamm Bretter, auf denen die Leute schlafen.

Keine Decken. Keine Matratzen.

Mücken.

Essen wird gespendet. Für alle hat die Spende nicht gereicht.

\section{Seite 85}

Die Familien haben durchschnittlich sieben Kinder.

Die Mütter waschen die Wäsche in den Regenpfützen vor der Baracke.

Die Flüsse sind durch Rinderleichen aus dem Landesinnern mit Typhus verseucht.

Durch die Überschwemmung der Flüsse geraten die Bazillen in die Trinkwasserreservoirs.

Die Behörden geben zu, dass sie das Trinkwasser nicht mehr ausreichend filter können.
A Tarde: 104 mortos. 1.400 casas destruídas por deslizamento de terra e chuva. 7.000 sem teto.

Tribuna da Bahia: $534 \mathrm{~mm}$ de chuva, a maior quantidade desde 1903.

A Tarde: perigo de tifo.

***

Os sem-teto, que primeiro foram alojados no Mercado de Curtume* , foram transportados para a barracas Esso.

Sob vigilância policial.

Três policiais estão em pé na entrada do terreno.

Cinco policiais na entrada da barraca em forma de galpão.

Piso de cimento. Lama. Na lama, tábuas sobre as quais as pessoas dormem.

Sem cobertas. Sem colchões.

Mosquitos.

Comida é doada. A doação não foi suficiente para todos.

\section{Página 85}

As famílias têm em média sete filhos.

As mães lavam as roupas nas poças d'água na frente da barraca.

***

Os rios estão contaminados com tifo por cadáveres de gado do interior do estado.

Pela enchente dos rios, os bacilos vão parar nos reservatórios de água potável.

Os órgãos públicos admitem que eles não conseguem mais filtrar o suficiente a água potável. 
Professor Valmor de Almeida Barreto von der Geologischen Fakultät in Bahia sagte vor fünf Jahren Erdrutsche voraus.

$\mathrm{Er}$ teilte die Ergebnisse einer Untersuchungskommission, dem damaligen Erzbischof Dom Eugenio Sales mit.

Freitag, den 30. April:

Dom Eugenio Sales sendet dem Gouverneur ein Telegramm, in dem er mitteilt, dass er für das Volk von Bahia bete.

Im Beifallspalast des Gouverneurs sammeln die Damen der Gesellschaft die Modelle der vergangenen Saison ein und tragen die Reste ihrer Hausapotheken für die Opfer zusammen.

Die Diener reichen in weissen Handschuhen Sandwiches und Erfrischungen:

- Alle helfen wir! Alle!

Im Mercado Popular sind ungefähr hundert Familien untergebracht. Sie hausen in den ehemaligen Verkaufsständen.

Das Wasser steht zehn Zentimeter hoch.

Keine Matratzen. Einige schlafen auf den Tonbänken.

Die meisten Kinder laufen nackt herum und tragen riesige, aufgedunsene Bäuche vor sich her.

Eine Toilette für alle.

Immer die gleiche Geschichte:

- Vor einer Woche kam der grosse Regen. Dann ist unser Haus zusammengefallen. Jetzt haben wir nichts mehr.
Professor Valmor de Almeida Barreto, da Faculdade de Geologia na Bahia, predisse há cinco anos o deslizamento de terra.

Ele comunicou os resultados de uma comissão de investigação ao então arcebispo Dom Eugenio Sales.

$* * *$

Sexta-feira, 30 de abril:

Dom Eugenio Sales envia ao governador um telegrama, no qual comunica que ele estaria orando pelo povo da Bahia.

$* * *$

No Palácio da Ovação do Governador reúnem as damas da sociedade os modelos da estação passada e recolhem os restos de sua farmácias domésticas para as vítimas.

Os criados entregam em luvas brancas sanduíches e refrescos:

- Nós ajudamos todos! Todos! $* * *$

No Mercado Popular estão abrigadas cerca de cem famílias. Elas habitam as antigas bancas de venda.

A água está em dez centímetros de altura.

Nenhum colchão. Alguns dormem em bancos de argila.

A maioria das crianças anda por ali peladas e carregam diante de si enormes e inchadas barrigas.

Um toilette para todos.

Sempre a mesma história:

- Há uma semana veio a grande chuva. Então nossa casa desmoronou. Agora nós não temos mais nada. 
Dabei fassen sie sich demonstrativ an die wenigen Kleider.

\section{Seite 86}

Sie sitzen teilnahmslos herum.

Leonores Apparat erregt Fröhlichkeit:

- Ein Foto! Ein Foto!

Maria, die Psychologiestudentin, berichtet, im Gerichtsmedizinischen Institut "Nina Rodrigues « liegen Haufen von ertrunkenen Kindern. Die Mütter suchen die ihren darunter hervor.

Sonntag, den 2. Mai:

Jornal do Brasil: Der Papst betet für die Opfer von Bahia.

Montag, den 3. Mai:

A Tarde: Kinderlähmung und Hepatitis.

Dienstag, den 4. Mai:

Tribuna da Bahia: Zwei Fälle von Typhus.

Drei Pockenfälle.

Mittwoch, den 5. Mai:

Jornal da Bahia: Kirche weist Vorwurf der Unterlassungssünde zurück.

Essen für die Obdachlosen fehlt.

In der Essobaracke sind die einzelnen Familien jetzt durch Seile abgetrennt. Jede
Enquanto falam, seguram de forma demonstrativa suas poucas roupas.

\section{Página 86}

Eles estão sentados por ali, apáticos.

O aparelho fotográfico de Leonore suscita alegria

- Uma foto! Uma foto!

***

Maria, a estudante de psicologia, relata que no Instituto de Medicina Legal "Nina Rodrigues" há um monte de crianças afogadas. As mães buscam os seus dentre eles.

Domingo, 2 de maio:

Jornal do Brasil: o Papa reza pelas vítimas da Bahia.

***

Segunda-feira, 3 de maio:

A Tarde: paralisia infantil e hepatite. $* * *$

Terça-feira, 4 de maio:

Tribuna da Bahia: dois casos de tifo.

Três casos de varíola.

***

Quarta-feira, 5 de maio:

Jornal da Bahia: a Igreja rejeita a crítica do pecado da omissão.

Falta comida para os sem-teto.

No acampamento Esso, as famílias são separadas individualmente por uma corda. Cada 
Familie hat etwa 4 Quadratmeter zur Verfügung.

Sonnabend, den 8. Mai:

Tribuna da Bahia: Vergiftetes Milchpulver im Hafen. Es hätte nicht viel daran gefehlt und 2 223 Säcke vergiftetes Milchpulver wären von der Bevölkerung verzehrt worden. Das Milchpulver, eine Gabe der brasilianischen Bischofskonferenz, sollte kostenlos verteilt werden. Es ist mit Ätzsoda vermischt und lagert in Schuppen drei.

Die Erlaubnis, das Milchpulver zu fotografieren, wurde nicht gegeben.

- 35 Fälle von Kinderlähmung.

\section{Seite 87}

In Arembepe, einem afrikanisch wirkenden Fischerdorf nahe Salvador, schützen die Einwohner ihre Lehmhäuser vor dem Regen mit Bastmatten, die sie aussen an die Wände stellen.

In Arembepe sind die Häuser bewahrt geblieben; es hat allerdings auch keinen Erdrutsch gegeben wie in der Stadt.

Auch in Arembepe Kinder mit Bäuchen, die so dick sind, wie die Kinder hoch - hier am Meer wie in der Essobaracke in der Stadt.

Mittwoch, den 12. Mai:

Jornal da Bahia:

Achtung, eine neue Krankheit! Leptospirose!

Sie wird durch Ratten übertragen und greift Nieren und Leber an. Es gibt kein Mittel dagegen. 12 Fälle im Krankenhaus Couto Maia.

- Promiskuität in der Essobaracke.

Viele Mütter beklagen sich, dass einige Ehepaare sogar am Tage Geschlechtsverkehr família tem cerca de 4 metros quadrados à disposição.

***

Sábado, 8 de maio:

Tribuna da Bahia: leite em pó envenenado no porto. Não teria faltado muito e 2.223 sacos de leite em pó envenenado teria sido consumido pela população. O leite em pó, uma doação da Conferência Brasileira dos Bispos, deveria ser distribuído sem custo. Ele é misturado com soda cáustica e está armazenado no galpão três.

A autorização para fotografar o leite em pó não foi dada.

- 35 casos de paralisia infantil.

\section{Página 87}

Em Arembepe, uma aldeia de pescadores com aspecto africano perto de Salvador, os habitantes protegem suas casas de pau-a-pique da chuva esteiras de ráfia, que eles colocam no lado de fora, nas paredes.

Em Arembepe as casas permaneceram conservadas; contudo, não houve nenhum deslizamento de terra como na cidade.

Também em Arembepe, crianças com barrigas, que são tão gordas como as crianças lá em cima - aqui no mar como na barraca Esso na cidade. ***

Quarta-feira, 12 de maio:

Jornal da Bahia:

Atenção, uma nova doença! Leptospirose!

Ela é transmitida por ratazanas e ataca rins e fígado. Não há remédio contra isso. 12 casos no hospital Couto Maia.

- Promiscuidade na barraca Esso.

Muitas mães se queixam que alguns casais até durante o dia teriam relação sexual, sem ter 
hätten, ohne auf die herumspielenden Kinder Rücksicht zu nehmen.

Die Polizisten vergewaltigen die jungen Mädchen.

C. redet ununterbrochen von den Göttern und betreibt zwischendurch eine Männervermittlung für begüterte Schwule.

Heute ist Sonnabend und in den Absteigen des heruntergekommenen Palastviertels Pelourinho stehen die Paare Schlange.

C. führt mich noch einmal durch die Falltür hinunter.

Er hat ein Zimmer für die Toten hergerichtet.

Es ist Weiss getüncht, in der Mitte ein schwarzes Kreuz mit einem langen weissen Band.

-Die Toten der Regenkatastrophe suchen mich heim. Ich leide ihr Leid und ich muss Feste für sie begehen, um sie zu besänftigen.

\section{Seite 88}

Drei Monate später gibt es noch immer Obdachlosenlager:

Die Essobaracke, die Atlantikbaracke, den Mercado Popular.

Es sind mehr Leute als vorher.

Im Mercado Popular Typhusfälle.

Die Bewohner der Obdachlosenlager haben sich Wände aus Holz und Pappe errichtet. Einige besitzen Betten oder wenigstens Matratzen oder Pferdedecken. Die meisten schlafen weiterhin auf Holzbrettern, zwischen Essensresten, Feuerchen und Exkrementen. Das Geschirr und die Wäsche werden immer noch in Pfützen gewaschen.

Fische werden in den Pfützen geputzt. consideração pelas crianças que brincavam por ali.

Os policiais estupram as moças jovens.

***

C. fala infindavelmente dos deuses e admnistra, entre uma coisa e outra, uma agência de mediação de homens para viados ricos.

Hoje é sábado e nos hoteizinhos baratos do bairro decadente dos palácios, Pelourinho, os casais fazem fila.

C. me conduz novamente para baixo pelo alçapão.

Ele preparou um quarto para os mortos.

Ele é caiado de branco, no meio uma cruz preta com uma comprida fita branca.

-Os mortos da catástrofe da chuva me procuram em segredo. Eu sofro seu sofrimento e eu tenho celebrar festas para apaziguá-los.

\section{Página 88}

Três meses mais tarde ainda há acampamentos de sem-teto:

As barracas Esso, a barraca Atlantik, o Mercado Popular.

São mais pessoas que antes.

No Mercado Popular*, casos de tifo.

Os moradores do acampamento de sem teto ergueram paredes de madeira e papelão. Alguns possuem camas ou pelo menos colchões ou manta para cavalo. A maioria continua dormindo em tábuas de madeira, entre restos de comida, fogueirinhas e excrementos. A louça e a roupa ainda são lavadas nas poças.

Peixes são limpos nas poças. 
Viele besitzen nur das, was sie auf dem Leibe haben.

Sie sagen aus den Verschlägen heraus:

- Kommen Sie in mein Haus!

***

»Bernardinho de Batefolha« - ein Candomblé der Kongo.

Bernardinchen, der Blätterschüttler, ist lange tot. Heute leitet Pedro den Tempel.

Pedro ist ein kleiner, zarter Mann.

In seinem Gesicht steht ein vom Verhängnis geschlagener Ausdruck; wenn er herrsüchtig, eitel, gewinngierig ist, werden diese Züge verdeckt vom alten Verhängnis.

Er begrüßt uns liebevoll und zurückhaltend.

Er müsse noch etwas erledigen.

Er geht mit zwei Blätterbüscheln zu einem umfriedeten Baum.

Er betritt mit einem Man die Umfriedung und beginnt die Blätterbüschel an dem Körper des Patienten zu schütteln:

Oben, unten, rechts, links, vorne, hinten.

Die Beschwörungskur gegen eine Krankheit oder gegen einen bösen Zauber.

Der Patient muss in eine Kammer gehen und die Kleider wechseln.

Pedro will uns den Kultraum und einige Heiligenhäuschen zeigen.

Wir gehen zu einem langgestreckten Haus hinüber. Wir ziehen hinter der Eingangstür die Schuhe aus.

Ein Altar, barock und naiv; auch hier fehlt nicht die Indianerfigur.
Muitos possuem somente o que eles têm no corpo.

Eles falam espontaneamente das paletes:

- Venha a minha casa!

***

»Bernardinho de Batefolha «* - um candomblé dos congos.

Bernardinho, o batedor de folhas, está morto há muito tempo.

Pedro é um homem pequeno, delicado.

Em seu rosto há uma expressão abatida pela fatalidade; quando ele tem ânsia de dominação, é vaidoso e ganancioso por lucro, esses traços são encobertos pela velha fatalidade.

Ele nos cumprimenta carinhosamente e retraído. Ele teria ainda que resolver algo.

Ele vai com dois tufos de folhas a uma árvore cercada.

Ele entra com um homem no cercado e começa a bater os tufos de folhas no corpo do paciente:

Em cima, embaixo, à direita, à esquerda, na frente, atrás.

A cura por conjuração contra uma doença ou contra um mau encantamento.

O paciente tem que entrar numa câmara e trocar de roupa.

Pedro quer nos mostrar a sala do culto e algumas casinhas sagradas.

Nós vamos a uma casa comprida do outro lado. Nós tiramos os sapatos atrás da porta de entrada.

Um altar, barroco e naiv; aqui também não falta a figura do índio. 
Ehe Pedro die Tür zum Altar der Göttin lansa, der Blitzheiligen Barbara, öffnet, klopft er mit dem Schlüssel an das Holz und

\section{Seite 89}

flüstert leise der Göttin zu, um sie auf unseren Besuch vorzubereiten.

In dem heiligen Raum viel weisses Geschirr.

Eine Schüssel voll Plastikspielzeug ist den göttlichen Zwillingen geweiht, sie sind hier vorübergehend einquartiert, wie auch Ogum, dessen Häuschen im Regen litt.

Pedro führt uns in das Zimmer von Oxala, dem Jesus Christus von Bomfim. Sehr lichte Farben hier, viel Weiss; silbrige und hellockerfarbene Krüge.

Das Tageslicht wird durch weissen Tüll an den Fernstern gefiltert.

Dieser Raum um die hingebungsvolle Gestalt des Kongonegers Pedro hat eine sirrende, mysthische Atmosphäre.

Das dritte Zimmer ist das des Blitz- und Feuergottes Xango. Eine Anhäufung von schwarzen, neolithischen Äxten, Blitzgestein in der Vorstellung des Afrikaners. Einige sind zentnerschwer, geölt oder in Öl gelagert.

Pedro zeigt uns das unermessliche, waldige Grundstück. Wir gehen an dem Heiligtum des Baumgottes Tempo vorüber. Hier finden die magischen Heilzeremonien statt.

Weissblau gefärbte Krüge.

Eine weisse Fahne im Geäst des heiligen Baumes.

Pedro führt uns in eine aus Bäumen gewachsene Kapelle.

Wir dürfen wieder kommen.
Antes que Pedro abra a porta para o altar da deusa lansã, a Santa Bárbara do Raio, ele dá batidinhas com a chave na madeira e

\section{Página 89}

sussurra baixo à deusa, preparando-a para nossa visita.

No quarto sagrado, muita louça branca.

Uma tigela cheia de brinquedos de plástico é consagrada aos gêmeos divinos, eles estão aqui aquartelados provisoriamente, como também Ogum, cuja casinha sofreu com a chuva.

Pedro nos conduz ao quarto de Oxalá, o Jesus Cristo do Bonfim. Cores muito luminosas aqui, muito branco; vasos prateados e de cor ocre clara.

A luz do dia é filtrada por um tule branco nas janelas.

Esse quarto e a figura devotada do Kongonegro Pedro tem uma atmosfera com um som de zunido, mística.

O terceiro quarto é o de Xangô, o deus do fogo e do raio. Um amontoado de machados pretos, neolíticos, pedra de raio na concepção do africano. Alguns são muito pesados, oleados ou armazenados em óleo.

Pedro nos mostra o terreno imensurável, florestal. Nós passamos pelo santuário do deus da árvore Tempo. Aqui acontecem as cerimônias mágicas de cura.

Vasos coloridos de alviazul.

Uma bandeira branca na ramagem da árvore sagrada.

Pedro nos conduz a uma capela formada de árvores.

Nós temos permissão para voltar. 
P. kommt aus Afrika zurück.

Auch an dem weisen $P$. geht die längere Haarmode nicht vorbei.

$P$. hat in Afrika nichts anderes getan, als sich die verschiedenen Tonhöhen bei der Aussprache von Pflanzennamen sagen lassen. Die Arbeit über die Intelektuellen Strukturen der Yoruba am Beispiel der Pflanzen und der Beschwörungsformeln wird ihn noch Jahre beschäftigen.

Er schreibt gerade einen Essay über die Erinnerungshilfen der Yoruba. Er sieht Analogien zu englischen und französischen Kinderreimen.

Es habe schon immer Gerüchte über Menschenopfer in Bahia gegeben. Letzlich sei sogar Olga de Alaketu in eine solche Affaire hineingezogen worden, weil man einen Ermordeten in der Nähe ihres Candomblés fand.

\section{Seite 90}

Dienstag, den 17. August:

Tribuna da Bahia:

Die Regierung gibt den Opfern der Regenkatastrophe vom April dieses Jahres heute 410 Häuser.

Die Häuser liegen in Mata Escuro und in Pau de Lima.

In weniger als 100 Tagen hat die Regierung mehr als 1575 Familien untergebracht.

Die 360 Wohnhäuser in Pau de Lima verfügen über alle hygienischen Einrichtungen: Wasser, Elektrizität, Kanalisation. Der Bus hält vor der Tür.

Von weitem wirkt die Siedlung ganz hübsch. Vorne ein Blechschild:
P. chega de volta da África.

Até para o sábio P. a moda do cabelo comprido não passa.

P. não fez nada na África além de deixar que lhe contassem sobre as diversas alturas dos tons na pronúncia dos nomes das plantas. O trabalho sobre as estruturas intelectuais dos yorubá a exemplo das plantas $e$ as fórmulas de conjuração ainda vai ocupá-lo por anos.

Ele está escrevendo um Essay sobre os auxílios à memória dos iorubás. Ele vê analogias com as rimas infantis do inglês e do francês.

Sempre houve boatos sobre sacrifícios humanos na Bahia. Por ultimo, até Olga de Alaketu teria sido envolvida em um caso desses, porque encontrou-se um assassinado perto do seu candomblé.

\section{Página 90}

Terça-feira, 17 de agosto:

Tribuna da Bahia:

O governo dá hoje às vítimas da catástrofe da chuva de abril desse ano 410 casas.

As casas ficam em Mata Escuro e em Pau de Lima.

Em menos de 100 dias, o governo abrigou mais de 1.575 famílias.

As 360 residências em Pau de Lima dispõem de todas as instalações higiênicas: água, eletricidade, canalização. O ônibus para diante da porta.

De longe, o assentamento parece bem bonito. Na frente, uma placa de lata: 
Siedlung Antonio Carlos Magalhaes.

Die Gouverneure vergessen nicht, ihre Wohltaten, wie Maler Bilder, mit einer Signatur zu versehen.

Die Häuser haben nur einen Raum. Etwa sechs mal sechs Meter.

Ein winziges Fenster, ohne Scheibe, nur mit einem Holzladen zu verschliessen.

Also entweder Dunkelheit oder Regen.

Bei geschlossener Tür ist es so finster, dass man nicht lesen oder arbeiten kann.

Kein fliessendes Wasser und keine Installationen, ausser, in dem einzigen Raum, einer Toilette ohne Brille und ohne Wasserspülung. Davor ein kleines Feuer zum Kochen.

Die Familie schläft auf einer Unterlage aus Steinen und Pappe.

Ein Lattenverschlag, in dem man Tiere auf dem Markt verkauft, für den Säugling.

Der Fussboden - Lehm. Er liegt tiefer als der Weg. Bei jedem Regen wird der Fussboden überschwemmt.

Ein paar hundert Meter entfernt gibt es einen Gemeinschaftsbrunnen, für etwa 3000 Personen.

Ein altes Gasthaus soll die Schule sein. Es ist verschlossen.

Zur Busstation ist es eine halbe Stunde. Manchmal kommt nur alle drei Stunden ein Bus.

Viele Familien leben ohne Vater.

Die Mutter muss Kinder durch Hausarbeit oder als Wäscherin ernähren.

\section{Seite 91}

Für die Frauen gibt es hier draussen keine Verdienstmöglichkeiten.
Assentamento Antonio Carlos Magalhaes.

Os governadores não esquecem de prover suas boas obras com uma assinatura, como pintores em seus quadros.

As casas têm somente um cômodo. Cerca de seis por seis metros.

Uma minúscula janela, sem vidro, só com uma folha de madeira para fechar.

Portanto, ou escuridão ou chuva.

Com a porta fechada é tão escuro que não se pode ler ou trabalhar.

Sem água corrente e sem instalações, além de, no único cômodo, um toilette sem assento sanitário e sem descarga de água. Na frente dele, um pequeno fogo para cozinhar.

A família dorme em uma base de pedra e papelão.

Um engradado de ripas, no qual se vendem animais no mercado, para o bebê.

O chão - barro. Localiza-se mais baixo que 0 caminho. Em cada chuva, o chão fica inundado.

A algumas centenas de metros distante, há uma fonte comunitária, para cerca de 3.000 pessoas.

Uma velha hospedaria deveria ser a escola. Ela está fechada.

Até à estação de ônibus é uma meia hora. Ás vezes só vem um ônibus a cada três horas.

Muitas famílias vivem sem pai.

A mãe tem que alimentar os filhos com trabalho doméstico ou como lavadeira.

\section{Página 91}

Para as mulheres não há aqui fora nenhuma possibilidade de ganho. 
Kein Arzt.

Kein Sanitätsposten.

Zu Pedro nach Batefolha: er zeigt mir das Wohnhaus, die Gästezimmer und einen kuriosen Saal voller verschnörkelter Stühle.

Das Portrait des mächtigen Gründers Bernardinho hängt an der Wand.

Bernardinho starb 1946.

Pedro ist, solange er lebt, ein geistlicher Sohn dieses Hauses.

Seit sechs Jahren leitet er es.

P.:

- Die Priester in Afrika haben keine sehr glorreiche Stellung. Sie sind dem König untertan. Sie sind Sklaven des Königs. Nur einmal haben sich die Priester gegen den König aufgelehnt.

Die Priester Omolus oder Obaluaes behaupteten, ihr Gott sei in Wahrheit der König der Welt.

Diese Priester haben aber auch die Fähigkeit, schwarze Pocken mit Kräutern zu heilen. Einer meiner Informanten in Dahomey ist so gerettet worden. Er hatte die Pocken bekommen, weil er mir zu viel über Omolu erzählt hat. Später wurde er verrückt.

- Der Candombléverein von Bahia hat ehemals mit der Polizei des Diktators Getulio Vargas zusammengearbeitet. Vargas versuchte den Candomblé in den Griff zu bekommen. Die Geistlichen sind sehr gegen die Obrigkeit eingestellt. Als der Ethnologe Edison Carneiro von der Polizei aus politischen Gründen gesucht wurde, verbarg die Mãe Senhora inn wochenlang in einem Heiligenhäuschen.

- Auch in Afrika gibt es mächtige Müttergestalten. Ihre Göttin ist lyami. Die Frauen haben in den Tempeln der Yoruba eine
Nenhum médico.

Nenhum posto de saúde.

Para o Pedro até Batefolha: ele me mostra a residência, os quartos de hóspedes e uma sala curiosa, cheia de cadeiras ornamentadas.

O portrait do poderoso fundador Bernardinho está pendurado na parede.

Bernardinho morreu em 1946.

Pedro é, enquanto ele viver, um filho spiritual dessa casa.

Há seis anos ele a dirige.

P.:

- Os sacerdotes na África não têm uma posição muito gloriosa. Eles estão subjugados ao rei. Eles são escravos do rei. Só uma vez os sacerdotes se rebelaram contra o rei.

Os sacerdotes de Omulú ou Obaluaê afirmam que seu deus é, na verdade, o rei do mundo.

Esses sacerdotes têm igualmente a capacidade de curar bexiga negra com ervas. Um dos meus informantes no Dahomey foi salvo assim. Ele pegou a bexiga, porque ele me contou muita coisa sobre Omulú. Mais tarde ele ficou louco.

- A associação de candomblé da Bahia trabalhou antigamente em colaboração com a polícia do ditador Getulio Vargas. Vargas tentou obter o controle sobre o candomblé. Os religiosos estão bastante posicionados contra a autoridade. Quando o etnólogo Edison Carneiro foi procurado pela polícia por motivos politicos, a Mãe Senhora* o escondeu durante semanas em uma casinha sagrada.

- Também na África há figuras maternas poderosas. Sua deusa é lyami. As mulheres têm nos templos dos Yorubá um poder inoficial. As 
inoffizielle Macht. Die Frauen in Bahia sind reicher als die Männer. Sie haben mehr Zeit. Die Familie bildet sich um die Mutter. Jede Frau hat Kinder von verschiedenen Vätern. Die Väter gehen vorüber. Die Frau spielt in der bahianischen Familie die

\section{Seite 92}

Rolle eines Negerkönigs. In Afrika ist alles um den Mann gruppiert, obwohl auch dort die Frauen oft reicher sind. In Afrika werden die Frauen von den Männern ausgenützt. Die grössere Beweglichkeit des Mannes in Bahia, die Frau als Zentrum der Familie - das sind natürliche Folgen der Sklaverei. In Bahia ist der Vater an seinen Kindern weitgehend desinteressiert.

- Man weiss so gut wie nichts über die physiologischen Vorgänge während der Trance.

- Was mit den Novizen während der Einweihungszeit geschieht, ist nicht genau bekannt. Es gilt als Tugend im Candomblé, nichts zu sagen. Es werden Kräutergetränke verabreicht.

Suggestion spielt eine Rolle, vielleicht auch Autosuggestion. Auf jeden Fall werden die Novizen völlig stumpfsinnig. Auch Trommelrhythmen sind wichtig. Man hat festgestellt, dass es Rhythmen im Candomblé gibt, bei denen die Leute einfach nicht still sitzenbleiben können.

Der Candomblé hat einen eigenen Moralkodex wie jede andre Religion auch. Die Enthaltsamkeit ist an bestimmten Tagen, zu bestimmten Festen vorgeschrieben. Diebstahl, Lüge, Mord sind verboten.

- Der katholische Glaube der Candombléanhänger in Bahia ist nicht echt. Er ist ein Spiel, ein sozial bedingtes Spiel. Durch den katholischen Glauben haben die Neger teil an der besseren Gesellschaft der Weissen. mulheres na Bahia são mais ricas que os homens. Elas têm mais tempo. A família se forma em torno da mãe. Toda mulher tem filhos de vários pais. Os pais são transitórios. A mulher desempenha na família bahiana

\section{Página 92}

o papel de um rei negro. Na África tudo é agrupado em torno do homem, embora lá também as mulheres sejam muitas vezes mais ricas. Na África as mulheres são usadas pelos homens. A maior mobilidade do homem na Bahia, a mulher como centro da família - isso são consequências naturais da escravidão. $\mathrm{Na}$ Bahia, o pai é amplamente desinteressado por seus filhos.

- Não se sabe quase nada sobre os processos fisiológicos durante o trance.

- O que acontece com as noviças durante o tempo da iniciação não é conhecido exatamente. Considera-se como virtude não se dizer nada no candomblé. São ministradas bebidas de ervas.

Sugestão desempenha um papel, talvez autosugestão também. De qualquer maneira, as noviças ficam completamente com os sentidos inertes. Os ritmos de tambor são importantes também. Constatou-se que há ritmos no candomblé, nos quais as pessoas simplesmente não podem ficar sentadas quietas.

O candomblé tem um próprio código moral, como qualquer outra religião. A abstinência é prescrita em determinados dias, em determinadas festas. Roubo, mentiras, assassinatos são proibidos.

- A fé católica dos adeptos do candomblé na Bahia não é verdadeira. Ela é um jogo, um jogo condicionado socialmente. Pela fé católica, os negros participam da melhor sociedade dos brancos. 
- Die Strafen im Candomblé sind Geldstrafen. Auch leichte Schläge. Niemand würde eine Mãe de Santo bei der Polizei anzeigen.

- Die Bezeichnung Candomblé ist wohl wie die Wörter Macumba, Makulele, Umbanda, Kimbanda eine Bezeichnung aus dem Kongo und meint ein Musikinstrument.

In Uruguay wird eine gewisse Trommel noch heute Candomblé genannt.

\section{Zu Pedro nach Batefolha.}

Ich wandre stundenlang durch Urwald, an armseligen Siedlungen vorbei.

Nackte Kinder mit den von Würmern dick aufgetriebenen Bäuchen.

Schrille Lautsprechermusik, die irgendein Politiker oder Lehrer oder Kramladen den Armen spendiert.

\section{Seite 93}

Die Elenden haben nicht einmal das Recht auf Stille.

Vielleicht finden sie den Lärm unterhaltsam.

Auf jeden Fall verweigert man ihnen die Möglichkeit, die Stille vorzuziehen.

Das alljährliche Fest bei Batefolha wird nicht stattfinden.

Ein Oga, ein hoher Würdenträger ist gestorben.

Pedro lädt mich zum Axexe ein.

Viele Andeutungen und Understatements.

Er bittet mich zum Essen und ich will mich dreimal rituell zurückziehen. Die Bestätigungen der Einladungen werden schliesslich unausweichlich.

Es wird das beste afrikanische Essen aufgetragen.
- As punições no candomblé são sanções pecuniárias. Também leves pancadas. Ninguém denunciaria uma Mãe de Santo* à polícia.

- A designanção candomblé é, bem como as palavras macumba, maculelê, umbanda, quimbanda, uma designação do Kongo e quer dizer um instrument musical.

No Uruguay, até hoje um determinado tambor é denominado candomblé.

***

Para o Pedro, ao Batefolha.

Eu vagueio durante horas pela mata nativa, passando por povoamentos miseráveis.

Crianças nuas com barrigas inchadas pelos vermes.

Música estridente de alto-falantes, que algum político ou professor ou uma mercearia doou aos pobres.

\section{Página 93}

Os miseráveis nem sequer têm direito ao silêncio.

Talvez eles achen o barulho divertido.

De qualquer modo, nega-se-Ihes a possibilidade de preferir o silêncio.

A festa anual no Batefolha não irá ocorrer.

Um ogã, um alto dignitário, morreu.

Pedro me convida para o axexê.

Muitas insinuações e understatements.

Ele me convida para comer e eu recuso três vezes, como num ritual. As confirmações dos convites tornam-se, por fim, inevitáveis.

O melhor da comida africana é servido. 
Zum Schluss richtet Pedro am Tisch der Männer einen Teller für die Götter an.

Ein Mädchen stellt inn nach draussen vor die Tür des Versammlungshauses. Sie sagt ins Leere hinein:

-Willst du was essen?

***

Erste Nacht des Axexe für einen Oga von Batefolha.

Pedro hat uns ausdrücklich für sieben Uhr abends bestellt.

Die Pforten des Grundstücks sind weit geöffnet.

Elektrische Birnen an den Gebäuden. Über der Pforte und an den Türen und Fenstern Palmblätter.

Wir sind die ersten Gäste. Wir warten im Freien.

Aus dem Wohnhaus kommt eine Prozession: Pedro und vier Gehilfen. Sie tragen die Opfergaben und die Kultgeräte in das Barracão, den Versammlungsraum. Dort wird alles mit einem weissen Tuch zugedeckt.

Leise gesungene Formeln, hohles, abebbendes Händeklatschen.

Ein Gehilfe kommt und führt uns auf die Veranda.

Dort plustern sich einige Würdenträger mit bigottem Klatsch auf.

Pedro und seine geistlichen Töchter gehen mit Opfern und Taschenlampen in den Urwald. Nach einer Stunde kehren sie zurück und begehen im Taschenlampenlicht eine Zeremonie vor dem Baum des Gottes Tempo.

Pedro begrüsst uns und ehe er noch Leonore ins Gesicht blickt, hat er schon die Tasche mit dem verborgenen Taperecorder gestreift. Er
Ao final, Pedro prepara à mesa dos homens um prato para os deuses.

Uma moça coloca-o diante da porta da casa de reuniões. Ela diz ao vazio adentro:

-Você quer comer alguma coisa?

***

Primeira noite de axexê para um ogã do Batefolha.

Pedro nos convocou expressamente para as sete horas da noite.

Os portões do terreno são largamente abertos.

Lâmpadas elétricas nos prédios. Acima dos portões e das portas e janelas, folhas de palmeira.

Nós somos os primeiros convidados. Nós esperamos ao ar livre.

Da residência vem uma procissão: Pedro e quatro auxiliares. Eles carregam as oferendas de sacríficio e os objetos do culto para o Barracão*, a sala de reunião. Lá tudo é coberto com um pano branco.

Formulas cantadas em voz baixa, bater palmas oco, enfraquecido.

Um auxiliar vem e nos conduz à varanda.

Lá alguns dignitários emproam-se com uma tagarelice beata.

Pedro e suas filhas espirituais vão com oferendas e lanternas à mata nativa. Depois de uma hora, eles voltam e celebram à luz da lanterna uma cerimônia diante da árvore do deus Tempo.

Pedro nos cumprimenta e antes de olhar Leonore no rosto, ele já passou os olhos na bolsa com o gravador escondido. Ele nos pede para depositar os casacos e 
bittet uns, die Mäntel und die Taschen in Verwahrung

\section{Seite 94}

zu geben. Er insistiert nicht, als wir über seinen Vorschlag hinweggehen.

Wir werden zum Essen eingeladen.

Leonore sitzt mit an der Männertafel - zu den eingeweihten Töchtern gehört sie keinenfalls. Diese essen à part.

Es sind nur die engsten Freunde des Candomblés versammelt und ich frage, ob wir nicht besser wieder gehen.

Pedro will nichts davon hören. Er drängt uns zu bleiben.

Pedro isst später allein.

Sein Stellvertreter isst nichts.

Die Schlagzeuger essen Fleisch. Keine Bohnen. Nudeln.

Vor dem Versammlungsraum wird den Männern eine Palmfaser um das Handgelenk gebunden, den Frauen um die Stirn.

Pedro und sein Stellvertreter versehen die Männer mit Schutzzeichen aus Pembapuder; die »Pequena Mãe« - die kleine Mutter betreut die Frauen. Ihr Gesicht ist wie eine Maske aus Ebenholz mit schmal auseinanderliegenden, fast parallelen Lidrändern.

Pedro setzt uns beide auf die Frauenseite, wo auch er und sein Stellvertreter Platz nehmen.

Pedro schüttet Schiesspulver au seiner kleinen Kürbisflasche von den Opfergaben bis zur Tür.

Explosionen und Dampf.

Erste Anrufungen der Götter.

\section{Página 94}

as bolsas. Ele não insiste, quando nós ignoramos sua sugestão.

Nós somos convidados para comer.

Leonore está sentada na mesa dos homens - às

filhas iniciadas, ela não pertence mesmo. Essas comem à part.

Somente os amigos mais íntimos do candomblé estão reunidos, e eu pergunto se não seria melhor nós irmos embora.

Pedro não quer saber de ouvir isso. Ele insiste para nós ficarmos.

Pedro come mais tarde, sozinho.

Seu substituto não come nada.

Os tocadores de tambor comem carne. Sem feijão. Macarrão.

$\mathrm{Na}$ frente da sala de reunião, amarra-se uma fibra de palmeira em volta do pulso dos homens, nas mulheres em volta da testa.

Pedro e seu representante marcam os homens com um sinal de proteção de pó de pemba; a "Pequena Mãe"* - die kleine Mutter - cuida das mulheres. Seu rosto é como uma máscara de ébano com pálpebras estreitas, separadas, quase paralelas.

Pedro coloca nós dois para sentar no lado das mulheres, onde ele e seu representante também se sentam.

Pedro verte pólvora de sua cabaça, das oferendas até a porta.

Explosões e vapor.

Primeiras invocações dos deuses. 
Hin und Hertrippeln der stehenden Trauergäste.

Wieder das hohle, abebbende Händeklatschen.

Das weisse Tuch wird hochgenommen.

Darunter vier Tonkrüge mit weissen und schwarzen Kreuzen und Kreisen bemalt. Zwei halbe Kalebassen in einer grünlichen Flüssigkeit in Tonschüsseln schwimmend. Zwei Vasen mit weissen und violetten Fahnen und schwarzen Totenkopffahnen. Zwei Kerzen auf silbernen Haltern. Vier Stöckchen, um die Kalebassen zu schlagen. Zuckerrohrschnaps für die Spieler und zum Begiessen der Instrumente.

Zweimal zehn Teller mit Opfermahlzeiten: Caruru, schwarze und braune Bohnen, Mais, verschiedene Sorten Mehl, Puffmais.

Am Axexe nehmen teil:

Pedro,

sein Stellvertreter,

ein dicker Würdenträger,

\section{Seite 95}

ein Würdenträger, der gelegentlich weint, ein andrer dicker Oga,

ein Junge, der in der Ecke sitzen muss,

ein stummer, ganz alter Afrikaner,

zwei Betrunkene,

ein betrunkener Trommler, er ist der Superstar unter den Schlagzeugern und weiss das,

einer mit einer Macke,

ein sehr ernsthafter,

einer mit Menjoubart;

die weissgekleideten Töchter von Pedro:

eine mit dickem Bauch,
Passos pequenos e rápidos para lá e para cá dos convidados do funeral que estão em pé.

Novamente o bater palmas oco e enfraquecido.

O pano branco é levantado.

Embaixo dele, quatro potes de barro pintados com cruzes e círculos brancos e pretos. Duas meia cabaças em um líquido esverdeado, nadando em tigelas de barro. Dois vasos com bandeiras brancas e violetas e bandeiras de caveira pretas. Quatro pauzinhos para bater nas cabaças. Aguardente de cana de açúcar para os tocadores e para a libação dos instrumentos.

Duas vezes dez pratos com refeições rituais: caruru, feijão preto e marrom, milho, diversos tipos de farinha, milho de pipoca.

Do axexê participam:

Pedro, seu substituto, um dignitário gordo,

\section{Página 95}

um dignitário, que ocasionalmente chora, um outro ogã gordo,

um menino que tem que ficar sentado no canto, um africano mudo, bem velho,

dois bêbados,

um tocador de tambor bêbado, ele é o superstar dos tocadores de tambor e sabe disso, um com um tique, um muito sério, um com uma barba Menjou; as filhas de Pedro, vestidas de branco: uma com uma barriga grande, 
eine mit behaarter Warze,

eine grosse magere,

eine hausfrauliche,

eine alte, mit weissen, geflochtenen Haaren und mädchenhaften Gliedern,

eine junge, die dienen muss,

die Pequena Mãe,

eine, die abseits sitzt und nicht tanzen darf;

als einzige Weisse:

Leonore,

ich.

Der zarte Pedro singt gewaltig und kann einzelnen Tönen eine unheimliche Resonanz geben.

Wechselgesänge zwischen Pedro und der Gemeinde.

Kongogesänge, auch Ketou und Angola.

Die Pequena Mãe respondiert mit einer sicheren Stimme, die über alle anderen tönt.

Die Kongogesänge erscheinen mir kunstvoller sehr eigentümliche Modulationen, leichte Mehrstimmgkeit.

Pedro sprüht Pemba in alle Ecken und rennt hinaus in den Urwald und sprüht auch im Freien Pemba.

Während seiner Abwesenheit Responsorien zwischen den Trommlern und den Töchtern der Götter.

Nach der Rückkunft von Pedro Zwiesprache mit dem Toten:

-Embora, rufen die Trommler und Pedro.

-Fort! Fort! uma com uma verruga cabeluda,

uma alta, magra,

uma dona de casa,

Uma velha, com cabelos brancos, trançados e membros de menina,

uma jovem, que tem que servir,

a Pequena Mãe*,

uma que está sentada afastada e não pode dançar;

como únicos brancos:

Leonore,

eu.

O suave Pedro canta poderosamente e pode dar a tons individuais uma enorme ressonância.

Cantos alternados entre Pedro e a comunidade.

Cantos do Kongo, também de Ketu e Angola.

A Pequena Mãe responde com uma voz firme, que ressoa sobre todas as outras.

Os cantos do Kongo me parecem mais plenos de arte; modulações muito próprias, leve polifonia.

Pedro pulveriza pemba em todos os cantos e corre lá fora, para a mata nativa e pulveriza pemba ao ar livre também.

Durante sua ausência, responsórios entre os tocadores de tambor e as filhas dos deuses.

Após a volta de Pedro, conversa com os mortos:

-Embora*, gritam os tocadores de tambor e Pedro.

-Fora! Fora! 
-Hast du es vergessen, sagt Pedro vor sich hin.

-Auf der anderen Seite, du Dede?

\section{Seite 96}

-Ja, Dede.

Pedro zieht wiederholt die Taschenuhr und sagt:

- Es ist schon halb zwölf.

- Geh schlafen, dann hören wir auch auf.

Ein Betrunkener drängt sich mit lauten Gesängen in das Geflüster Pedros - zu grosser liturgischer Heiterkeit der frommen Damen.

Pedro ruft inn unauffällig zurecht.

Einmal, als Pedro mit dem Toten spricht, nimmt der Betrunkene es für bare Münze und antwortet an Stelle des Toten, ohne es zu wissen.

An dem bleichen Schweigen der anderen begreift er, was geschehen ist und er sagt:

- Sou coitado!

- Ich Elendiger!

Später entschuldigt er sich trommelnd.

Pedro lächelt.

Pedro, sein Stellvertreter und ein Oga verteilen jeder zwei kleine Münzen an die Töchter. Die nehmen in jede Hand eine Münze, tanzen vor den Opfergerichten, verstreuen etwas Mehl aus den Tellern und geben die Münzen an andre Töchter weiter.

Einige vollführen mit den Münzen eine Kreisbewegung um den Kopf und werfen die Münzen auf den Boden.

Pedro verteilt neue Münzen.

Kleingeldprobleme. Scheine werden gewechselt.
-Você esqueceu disso, diz Pedro para si.

-Do outro lado, você, Dede?

\section{Página 96}

-Sim, Dede.

Pedro puxa repetidamente o relógio de bolso e diz:

- Já são onze e meia.

- Vá dormir, então nós terminamos.

Um bêbado se amontoa com cantos altos nos murmúrios de Pedro - para a grande hilaridade litúrgica das devotas damas.

Pedro o repreende discretamente.

Uma vez, quando Pedro fala com o morto, o bêbado toma isso literalmente e responde no lugar do morto, sem o saber.

No calar pálido dos outros, ele compreende 0 que está acontecendo e ele diz:

- Sou coitado!

- Eu, miserável!

Mais tarde ele se desculpa batucando.

Pedro sorri.

Pedro, seu substituto e um ogã distribuem cada um duas pequenas moedas às filhas. Elas tomam em cada mão uma moeda, dançam diante dos pratos rituais, dispersam um pouco de farinha dos pratos e passam as moedas para frente, a outras filhas.

Algumas executam com as moedas um movimento em círculo ao redor da cabeça e jogam as moedas no chão.

Pedro distribui novas moedas.

Problemas com dinheiro miúdo. Notas são trocadas. 
Die Choreographie dieses Münzetanzes ist kompliziert. In welcher Reihenfolge tanzen die Mädchen? Welche müssen die Münzen weitergeben? Welche dürfen sie auf dem Boden ablegen?

Welche Bedeutung hat das alles?

Pause. Kaffee.

Es wird wieder Essen serviert.

Die Betrunkenen genieren sich beim Essen.

Pedro meint wohl, wir hätten Fotoapparate in den Taschen. Ich versichere, dass wir keine Fotos machen wollen. Er ist beruhigt und ich bin froh, ihn nicht belügen zu müssen.

Nach einer Stunde geht es mit anderen Gesängen weiter.

Pedro hebt jetzt nicht mehr so schnell die Hand, um anzudeuten, dass der nächste Heilige angerufen werden kann.

Schliesslich werden die Palmfasern abgenommen und gebündelt $\mathrm{zu}$ den Kultgegenständen gelegt.

\section{Seite 97}

Jetzt fallen zwei Töchter in Trance. Sie schreien Hei! - eine dicke und die weisshaarige - und flattern in die Nacht hinaus. Nach ein paar Minuten macht Pedro sich mit einem Oga auf die Suche nach den Besessenen und bringt sie zurück.

Das weisse Tülltuch wird über die Trommler gehalten. Sie ziehen sich schon von ihren Sitzen zurück, trommeln aber noch weiter und erst, als das Tuch schon auf ihre Hände fällt, hören sie auf, werfen die Stöckchen und die kleinen Palmmatten unter das Tuch und springen weg.

Pedro lädt uns zum Ausruhen ein.
A coreografia dessa dança das moedas é complicada. Em que sequência as moças dançam? Quais têm que passar as moeadas para frente? Quais elas podem colocar no chão?

Que significado tem isso tudo?

Pausa. Café.

Serve-se comida novamente.

Os bêbados se envergonham ao comer.

Pedro acha mesmo que nós teríamos aparelhos fotográficos nas bolsas. Eu garanto que nós não queremos tirar nenhuma foto. Ele se tranquiliza e eu estou contente de não ter que mentir para ele.

Uma hora depois, continuam com outros cantos.

Pedro agora não ergue a mão tão rápido para insinuar que o próximo santo pode ser invocado.

Por fim, as fibras de palmeira são retiradas e colocadas em feixe junto dos objetos de culto.

\section{Página 97}

Agora duas filhas caem em transe. Elas gritam Hei! - uma gorda e uma de cabelos brancos - e esvoaçam para fora, noite adentro. Alguns minutos depois, Pedro sai com um ogã à procura das possuídas e as traz de volta.

O pano branco de tule é conservado sobre os tocadores de tambor. Eles já se retiram de seus assentos, continuam a tocar tambor e só terminam quando o pano cai em suas mãos, jogam as varetinhas e as pequenas esteiras de palmeira debaixo do pano e saltam para fora.

Pedro nos convida ao descanso. 
Unter gar keinen Umständen will er uns durch die Nacht gehen lassen. Ich hatte mich auf den Heimweg im Dunkeln gefreut.

Aber mir fällt ein, dass es Axexes gibt, wo man eine Woche lang den Versammlungsraum nicht verlassen darf.

Da wir an der für alle drei Nächte bindenden ersten Zeremonie teilgenommen haben Pedro wollte uns diese Verpflichtung ersparen und hatte uns erst nur für den zweiten Abend bestellt -, fügen wir uns und erstarren in zwei verschnörkelten Stühlen, aufgeschreckt von den Urwaldvögeln, die der Priester in Käfigen hält. Als wir aufstehen, ist die kleine dienende Tochter da und bringt Waschwasser und Kaffee.

Sie trägt eine blutige Schürze.

Sie begleitet uns bis an die Pforte des Grundstücks.

Schüsseln und Krüge stehen an den heiligen Bäumen.

Um diese Stunde des Sonnenaufgangs pendeln die Bahianer wie irr zwischen Schlaf und Wachen.

Die Autos rasen, als würden sie von Betrunkenen oder Süchtigen gesteuert.

Freitag, den 27. August:

Die Zeitung »Tribuna da Bahia erscheint verspätet und in kleiner Auflage. An den meisten Zeitungsständen ist sie nicht zu bekommen.

Vergriffen oder beschlagnahmt?

Die Zeitungsverkäufer äussern sich nicht.

- Die Regierung zahlte Obdachlosen, die kein Haus abbekommen haben, 300 bis 400 Cruzeiros aus.
De maneira alguma ele quer nos deixar ir embora no meio da noite. Eu já havia ficado feliz com a ida para casa no escuro.

Mas me ocorre que há axexês em que a sala de reunião não pode ser deixada durante uma semana.

Já que nós tomamos parte das primeiras cerimônias vinculadas a todas as três noites Pedro quis nos poupar dessa obrigação e nos designou apenas para a segunda noite -, nós nos submetemos e sentamos petrificados em duas cadeiras ornamentadas com arabescos, assustados pelos pássaros da mata nativa, que o sacerdote mantém em gaiolas. Quando nós nos levantamos, a pequena filha a serviço está lá e traz água de lavagem e café.

Ela está vestindo um avental ensanguentado.

Ela nos acompanha até o portão do terreno.

Tigelas e potes estão nas árvores sagradas.

Nessas horas do erguer do sol os bahianos oscilam como insanos entre o sono e o despertar.

Os automóveis correm a toda velocidade, como se fossem guiados por bêbados ou viciados. ***

Sexta-feira, 27 de Agosto:

O jornal "Tribuna da Bahia" sai atrasado em pequena tiragem. Na maioria das bancas de jornal não se pode adquiri-lo.

Esgotado ou apreendido?

Os vendedores de jornal não se pronunciam. ***

- O governo pagou aos sem-teto que não receberam casa, 300 a 400 cruzeiros. 


\section{Seite 98}

- Dona Ivona hat vor einigen Tagen mit Kaiserschnitt einen Jungen geboren. Die Wunde hat sich infiziert. Sie muss ausserdem einen vierjährigen Jungen versorgen. Sie wurde gezwungen, 400 Cruzeiros anzunehmen. Ein Haus wollte man ihr nicht bewilligen ..

- Nach Ausbezahlung der 300 bis 400 Cruzeiros gibt es für den Staat vom heutigen Tage an keine Obdachlosen der Regenkatastrophe mehr.

\section{Zweiter Abend des Axexe:}

Wir sollen um neun kommen und warten dann mehr als eine Stunde, bis es beginnt. Aber Pedro muss einen frühen Zeitpunkt nennen, um jede Verspätung, Autopanne, etc. aufzufangen, sonst stehen die Verspäteten schutzlos um das Haus, wo die Toten herumirren.

Heute ist Cocunda da Yaya gekommen - eine steinalte Afrikanerin. Für sie wird ein eiserner Ehrensessel in den Versammlungsraum getragen.

Heute nehmen 42 Personen an dem Totenfest teil; später kommt ein ganz vom Regen Durchnässter hinzu. Ihm wird das Palmbändchen im Barracão selbst umgebunden und während die anderen singen, zeichnet Pedro ihm die weissen Kreuze auf.

Wieder das Entzünden des Schiesspulvers.

Pedro zeichnet fünf Kreuze aus Schiesspulver auf den Boden.

Ich entdecke unter den Kultgegenständen auch zwei Teller mit je zwei halben Colanüssen, die zur Weissagung dienen.

Der Stellvertreter holt aus dem Wohnhaus ein tönernes Gefäß voller Holzkohle.

\section{Página 98}

- Dona Ivona deu à luz um menino há alguns dias por incisão cesariana. A ferida infeccionou. Ela tem, além disso, que cuidar de um menino de quatro anos. Ela foi obrigada a aceitar 400 cruzeiros. Uma casa não queriam the conceder

- Após o pagamento de 300 a 400 cruzeiros, não há para o estado, a partir do dia de hoje, mais nenhum sem-teto da catástrofe da chuva.

$* * *$

Segunda noite do axexê:

Nós devemos chegar às nove e esperamos então mais de uma hora, até que comece. Mas Pedro tem que estabelecer um horário mais cedo, para interceptar qualquer atraso, pane do automóvel, etc., senão os atrasados ficam desprotegidos em volta da casa onde os mortos vagueiam.

Hoje, Cocunda da Yaya chegou - uma africana vetusta. Para ela carrega-se um poltrona de honra de ferro na sala de reunião.

Hoje tomam parte 42 pessoas na festa dos mortos; mais tarde chega mais um todo molhado de chuva. Nele a tirinha de palmeira é amarrada no próprio Barracão e enquanto os outros cantam, Pedro desenha nele as cruzes brancas.

Novamente o acender da pólvora.

Pedro desenha cinco cruzes de pólvora no chão.

Eu descubro entre os objetos do culto também dois pratos com duas meias nozes-de-cola cada, que servem para a profecia.

O substituto pega da casa um recipiente de barro cheio de carvão vegetal. 
Pedro wirft Weihrauch darauf und räuchert die Schlagzeuger ein.

Heute ist mir der Münzenreigen durchsichtiger:

Die Tanzenden geben jeder kleine Münzen an einen Oga, der gibt sie an andre Tanzende weiter. Hat er eine gewisse Menge beisammen, wirft er die Münzen auf den Boden. Hat einer das Geld weitergegeben oder auf den Boden geworfen, nimmt er etwas Sand von einem Haufen zwischen den Kultgegenständen und etwas Mehl von den Opfertellern und streut beides auf den Boden.

Heute spricht niemand mehr mit dem Toten.

\section{Seite 99}

Auch die Greisin Cocunda de Yaya tanzt. Sie bewegt sich sehr langsam. Pedro lässt sie den Reigen anführen.

In der Pause gibt es Vatapa, einen Maisbrei, und Kaffee.

Ob wir Brot lieber möchten?

- Nein?

Während der Gesänge Pedros schliesst Cocunda de Yaya die Augen. Sie schläft nicht. Sie vollführt jede Geste des Kultes pünktlich, nur fragmentarisch. Andeutungsweise stützt sie sich hoch, wenn der Ritus verlangt, dass die Gläubigen aufstehen.

Im Februar wird ein zweites Axexe für den Oga abgehalten werden. Sieben Nächte lang, nicht drei.

Durch das Klappern auf den Kalebassen, das Hallen der Tonkrüge konzentriert sich die Denkfähigkeit. Die Musik prägt sich überscharf ein. Erinnerung von Details der Zeremonie. Daneben Dumpfheit, Unlust sich zu regen, Schwindel, Übelkeit.
Pedro joga incenso em cima dele e defuma os tocadores de tambor.

Hoje a ciranda de moedas está mais transparente para mim:

Os dançarinos dão cada uma pequenas moedas a um ogã, este as passa a outros dançarinos. Quando ele juntou uma certa quantidade, ele joga as moedas no chão. Quando um passou o dinheiro ou o jogou no chão, ele pega um pouco de areia de um monte entre os objetos do culto e um pouco de farinha dos pratos de sacrifício e espalha ambos no chão.

Hoje ninguém mais fala com o morto.

\section{Página 99}

Até a anciã Cocunda de Yaya dança. Ela se movimenta muito devagar. Pedro deixa que ela lidere a ciranda.

Na pausa há vatapa, um mingau de milho e café.

Se nós preferimos pão?

- Não?

Durante os cantos de Pedro, Cocunda de Yaya fecha os olhos. Ela não dorme. Ela executa cada gesto do culto pontualmente, somente de modo fragmentário. De forma alusiva, ela se ergue amparando-se, quando o rito exige que os crentes se levantem.

Em fevereiro será celebrado um segundo axexê para o ogã. Por sete noites, não três.

Pelo chocalhar nas cabaças, o ecoar dos potes de barro, se concentra a capacidade de raciocínio. A música imprime sua marca superaguda. Lembranças de detalhes da cerimônia. Ao lado, torpor, falta de vontade de se mexer, tontura, nausea. 
Einige junge Leute schlafen fast krampfartig ein. Einer schläft sitzend, der Kopf hängt inm zwischen die Schenkel.

Dona Maria Paz da Costa erhielt kein Haus zugewiesen.

Sie hat sich das Bein gebrochen. Es wurde auf der Sanitätsstation eingegipst.

Als der behandelnde Arzt erfuhr, dass Dona Maria ohne festen Wohnsitz ist, beauftragte er den Fahrer der Ambulanz, die Kranke auf der Strasse abzuladen.

Studenten fanden die Frau und brachten sie in das Krankenhaus des Heiligen Antonius.

Es ist nicht das erste Mal, dass Ambulanzen Kranke auf die Strasse legen.

Dritter Abend des Axexe:

Als wir um neun kommen, hat es schon angefangen. Wir wollen umkehren, um keine rituellen Schwierigkeiten zu verursachen, aber Pedro nötigt uns zum Bleiben.

Die Gemeinde ist grosser als die beiden vorigen Male.

Antonio trommelt heute mit, dessen Tochter bei Professora Theresa eingeweiht wurde, der auch bei dem Axexe für Joãozinho da Gomeia getrommelt hat.

\section{Seite 100}

Ähnliche Riten wie an den vorhergehenden Abenden.

Jeder Gott wird heute etwas länger angesungen.

Verstehe ich jetzt den Münzenreigen richtig?

Ein höhergestellter Geistlicher gibt rangniederen zwei Münzen, dass diese sie zu den Opfermahlzeiten tragen, dort sammelt ein
Algumas pessoas jovens adormecem quase de forma convulsiva. Um dorme sentado, a cabeça Ihe pende por entre as coxas.

A Dona Maria Paz da Costa não foi atribuída nenhuma casa.

Ela quebrou a perna. Esta foi engessada no posto de saúde.

Quando o médico medicante ficou sabendo que Dona Maria está sem moradia fixa, ele encarregou o motorista da ambulância de descarregar a doente na rua.

Estudantes encontraram a mulher e levaram-na ao Hospital de Santo Antônio.

Não é a primeira vez que ambulatórios colocam doentes na rua.

***

Terceira noite do axexê:

Quando nós chegamos, às nove, ele já começou. Nós queremos voltar, para não causar nenhuma dificuldade ao rito, mas Pedro nos obriga a ficar.

A comunidade é maior que nas outras duas vezes.

Antonio não está tocando tambor hoje, cuja filha foi iniciada pela Professora Theresa, ele que também tocou tambor no axexê de Joãozinho da Gomeia.

\section{Página 100}

Rituais semelhantes aos das noites anteriores.

Para cada deus canta-se hoje por mais tempo.

Estou entendendo agora a ciranda de moedas direito?

Um religioso de posição mais elevada dà aos de menor escalão duas moedas, que estes levam até as refeições de sacrifício, lá um superior as 
Oberer sie ein, wirft sie zu einem Haufen und gibt zwei Münzen einem gleichgestellten, dass der inn beim Einsammeln ersetze.

Gegen vier Uhr morgens stellen die Oga die Kultgegenstände zusammen. Auch der geringste Rest wird eingesammelt. Die Kreidezeichnung auf dem Boden wird deutlich:

Ein fünfeckiger Stern voller schwarzer und weisser Kreuze, davor ein Halbkreis. Die Zeichen werden mit einem feuchten Tuch gelöscht.

Die Ogas bringen alles zusammengebündelt nach draussen vor den Baum Tempos. Eigentlich darf man nicht nach draussen sehen. Ich erspähe, dass die Gegenstände nach Zeremonien vor Tempos Baum in den Urwald getragen werden. Dort soll man sie eingraben oder auch an einem Flusslauf oder am Gestade des Meeres.

Die Leute schlafen.

Auch Cocunda de Yaya schläft. Sie bedeck ihr Gesicht zur Hälfte mit einem weissen Schal.

Andre schwätzen. Es bilden sich Gruppen von Altergenossen: Pubertierende Jungen, heiratsfähige Mädchen, die Männer um dreissig, die älteren Männer, die älteren Frauen.

Antonio gehört einer Gruppe von vier Trommlern an, die Nacht für Nacht durch Bahia ziehen und bei Götterfesten und Axexes spielen. Sie fordern kein Geld, aber es ist Usus, dass man innen etwas bezahlt.

Einer der Schlagzeuger sagt:

-Ich habe seit sechs Jahren keine Nacht geschlafen!

Die Trommler sind hart zueinander. Einer ist eingeschlafen. Sie drehen ihm die Ohren um, ohrfeigen inn - er schläft immer wieder ein; jedesmal wird er wieder geweckt. Er wagt es nicht, sich an seinen Peinigern zu rächen. Er recolhe, joga-as em um monte e dá duas moedas a um de posição equivalente, para que ele o substitua na coleta.

Por volta das quatro horas da manhã, os ogãs arrumam os objetos do culto. Até o mínimo restante é recolhido. $O$ desenho de giz no chão torna-se nítido:

Uma estrela de cinco pontas cheia de cruzes pretas e brancas, na frente um semicírculo. Os desenhos são apagados com um pano úmido.

Os ogãs levam tudo juntado em feixes para fora, diante da árvore do Tempo. Na verdade não se pode olhar para fora. Eu espio que os objetos são levados para diante da árvore do tempo na mata. Lá devem enterrá-los ou também junto ao fluxo de um rio ou na beira do mar.

As pessoas estão dormindo.

Cocunda de Yaya também está dormindo. Ela cobre seu rosto pela metade com um xale branco.

Outros tagarelam. Formam-se grupos de pessoas da mesma idade: meninos na puberdade, mocinhas casadouras, os homens em torno dos trinta, os homens idosos, as mulheres idosas.

Antonio pertence ao grupo dos quatro tocadores de tambor que se arrastam noite por noite pela Bahia e tocam nas festas dos deuses e axexês. Eles não solicitam nenhum dinheiro, mas é uso que lhe paguem algo.

Um dos tocadores de tambor diz:

- Eu não durmo há seis anos nenhuma noite!

Os tocadores de tambor são duros uns com os outros. Um deles adormeceu. Eles Ihe torcem as orelhas, Ihe esbofeteiam - ele continua dormindo; cada vez, ele é acordado novamente. 
schlägt einem anderen Schlafenden den Fuss zur Seite.

Nach zwei Stunden kommen Pedro und die Ogas zurück.

Alles Licht aus.

Nur auf dem Altar brennt eine einzelne Kerze.

Niemand darf zur Eingangstür sehen.

Die von der Göttin lansa Besessenen gehen in der Stille schnau-

\section{Seite 101}

fend im Versammlungsraum umher. Sie stossen den Schrei der Göttin aus.

Das elektrische Licht geht an. Die Trommeln werden geholt.

Befreit trommeln die Trommler auf den Trommeln der Lebenden.

Pedro schlägt die Doppelglocke des Agogo.

Die Zeremonie endet mit einer Anrufung des Herrn Jesus Christus.

Die lansas umarmen Pedro, die Ogas, Leonore, mich.

Jetzt lässt Pedro uns gehen. Wir wandern durch das armselige Dorf.

Ein Chevroletlaster mit Geistlichen holt uns ein und lässt uns aufsteigen. Einer der Ogas arbeitet auf dem Flugplatz in der Aeronautik. Er geht mit den vom Opferblut bespritzten weissen Hosen zur Arbeit.

Meistens würde nur die Göttin lansa bei den Axexes herabsteigen - aber auch Ogum und Omulu, aber seltener, manchmal auch Oxossi.

P.:

- Die Zeit heisst auf Yoruba Agogo oder richtiger Akoko, wird aber mit der Bezeichnung
Ele não ousa se vingar de seus agressores. Ele empurra o pé de um adormecido para o lado.

Depois de duas horas, Pedro e os ogãs voltam.

Todas as luzes apagadas.

Só no altar queima uma única vela.

Ninguém pode olhar para a porta de entrada.

Os possuídos pela deusa lansã andam arfando no silêncio

\section{Página 101}

à volta da sala de reunião. Eles soltam o grito da deusa.

A luz elétrica é acesa. Os tambores são recolhidos.

Libertos, os tocadores de tambor tocam nos tambores dos vivos.

Pedro bate o sino duplo do agogô.

A cerimônia termina com uma invocação ao Senhor Jesus Christus.

As lansãs abraçam Pedro, as ogãs, Leonore, a mim.

Agora Pedro nos deixa ir. Nós vagueamos pelo lugarejo miserável.

Uma caminhonete Chevrolet com religiosos nos pega e nos deixa subir. Um dos ogãs trabalha no campo de aviação da aeronáutica. Ele vai para o trabalho com as calças brancas salpicadas de sangue dos sacrifícios.

Geralmente, só a deusa lansã baixaria nos axexês - mas também Ogum e Omulu, mas mais raramente, às vezes também Oxóssi.

P.:

- O tempo se chama em lorubá Agogô ou, mais corretamente, Akoko, mas é confundido com a 
für die Doppelglocke im Candomblé ausgetauscht. Die Uhr heisst ebenfalls Agogo.

- Es gibt keinen Gott der Zeit bei den Yoruba.

- Auch das Musikinstrument hat keinen Gott. Es gibt die vage Idee eines Gottes de Musik.

- Für das Fragen nach der Uhrzeit beim Axexe habe ich auch keine Deutung.

- Es gibt Leute, die behaupten, die Yoruba kämen aus Ägypten, aus Nubien. Aber stichhaltige Beweise kenne ich dafür nicht.

- Nicht die Yoruba, die Ibos töten die Zwillinge. Die Yoruba verehren sie. Natürlich ist das nur die Kehrseite der Medaille. Aber wenn man in der Anthropologie und der Ethnologie vorgeht wie die Psychoanalytiker, kann man immer alles auf jede Weise erklären.

- Die Hilari sind Eunuchen und dienten am Königshof vielleicht auch zu sexuellen Zwecken. Auf jeden Fall hatten sie Frauenfrisuren.

- Der Oga, der Würdenträger in einem Candomblé, der die Trommeln schlagen darf, fällt nicht in Trance. Wie könnte er sonst die Trommeln beherrschen und mit den Trommeln die Götter zwingen, herunterzusteigen.

\section{Seite 102}

- Vielleicht mokiert man sich auch ein bisschen über die Leute in ihrer Besessenheit. Sicherlich, es sind die Götter, aber man äfft ihr absonderliches Verhalten auch gern ein bisschen nach.

- Die zerfaserten Palmblätter sind das Zeichen Ogums. Er hat die Macht, die Toten abzuwehren. Zerfaserte Palmblätter waren ehemals die Kleider Ogums.

- Das weisse Fähnchen unter den Kultgegenständen beim Axexe symbolisiert den Tag, die schwarze Fahne ist die Nacht, die designação do sino duplo no candomblé. O relógio também se chama Agogo.

- Não há nenhum deus do tempo nos Yorubás.

- O instrumento musical também não tem nenhum deus. Há uma vaga ideia de um deus da música.

- Para a pergunta sobre o horário no axexê, eu também não tenho nenhuma interpretação.

- Há pessoas que afirmam que os Yorubá viriam do Egito, da Núbia. Mas provas conclusivas disso eu não conheço.

- Não os yorubás, os lbos matam os gêmeos. Os yorubás os veneram. Naturalmente, isso só é o outro lado da moeda. Mas quando, na antropologia e na etnologia se procede como os psicanalistas, pode-se sempre explicar tudo de algum modo.

- Os Hilari são eunucos e servem na corte real talvez também para fins sexuais. Em todo caso, eles tinham penteados femininos.

- O ogã, o dignitário em um candomblé, que pode bater os tambores, não cai em transe. Como poderia ele de outro modo dominar os tambores e, com os tambores, forçar os deuses a descer.

\section{Página 102}

- Talvez se zombe também um pouco das pessoas em seu transe. Certamente que são os deuses, mas sente-se prazer em imitar simiescamente seu comportamento esquisito.

- As folhas de palmeira desfibradas são o símbolo de Ogum. Ele tem o poder de afastar os mortos. Folhas de palmeira desfibradas eram antigamente as vestes de Ogum.

- A bandeirinha branca sob os objetos de culto no axexê simbolizam o dia, a bandeira preta é a noite, a bandeira vermelha é o erguer do sol e o ocaso do sol. 
rote Fahne ist der Sonnenaufgang und der Sonnenuntergang.

- Der Münzentanz hat sicher nichts mit dem Totenpfennig für Charon zu tun; auch nichts mit dem französischen Sprichwort: Ma pièce de dix sous est pour les croquemorts. Es ist einfach eine afrikanische Sitte, den Tänzern zum Dank eine kleine Münze zu schenken. Man klebt innen die Münze auch an die schweissige Stirn.

- Die Bestrafung in den afrikanischen Heiligtümern kann sehr hart sein. Ich habe in einem Xangotempel erlebt, dass sein Gläubiger heftig ausgepeitscht wurde, weil er schlecht von einem Mitglied der Gemeinde geredet hatte.

- In meiner Kartei sind jetzt 3000 Pflanzen. Medizinalpflanzen. Keine Pflanzen, die für die Einweihungsgetränke benützt werden. Über diese Einweihungsgetränke in Afrika etwas zu erfahren, ist sehr schwierig. Es scheint mir aber, dass diese Getränke sich in Afrika und Bahia ähneln.

- Sicher besteht der Einweihungstrank Abó nicht aus 106 Pflanzen, sondern vielleicht nur aus sieben. Es gibt verschiedene solcher Getränke. Jeder Gott hat bestimmte Kräuter. Einige Kräuter gelten für alle Götter.

$* * *$

Es kommt ein Mann zu Besuch, der die Kulturpolitik der Bundesrepublik in der ganzen Welt bestimmt. Curtiusschüler. Ich habe Curtiusschülern viel zu verdanken und möchte inn bei Pedro einführen, dessen geistliche Stellung in Bahia man vielleicht mit der eines Patriarchen, eines Kardinals vergleichen kann.

Der Curtiusschüler hat sich beim Essen in der Stadt bekleckert. Er behält für seinen Besuch in Batefolha das bekleckerte Hemd an. Auch ich schätze bekleckerte Hemden und wünschte, man würde Diktatoren und Wirtschaftsbosse mit bekleckerten Hemden
- A dança das moedas certamente não tem nada a ver com o Pfennig dos mortos para Caronte; também não com o ditado francês: Ma pièce de dix sous est pour les croquemorts. É simplesmente um costume africano, de presentear uma pequena moeda como agradecimento aos dançarinos. Cola-se-lhes a moeda também na testa suada.

- A punição nos santuários africanos pode ser muito dura. Eu vivenciei num templo de Xangô, que seu fiel foi chicoteado violentamente porque ele havia falado mal de um membro da comunidade.

- No meu arquivo há agora 3.000 plantas. Plantas medicinais. Nenhuma planta que seja usada para as bebidas de iniciação. Ficar sabendo sobre essas bebidas de iniciação na África, é difícil. Mas parece-me que essas bebidas se assemelham na África e na Bahia.

- Certamente, a beberagem de iniciação, Abó, não consiste de 106 plantas, mas talvez de sete somente. Há várias de tais bebidas. Cada deus tem determinadas ervas. Algumas ervas valem para todos os deuses.

$* * *$

Um homem vem de visita, aquele que determina a política cultural da República Federal no mundo todo. Curtiusschüler. Eu tenho muito a agradecer a Curtiusschüler e gostaria de apresentá-lo a Pedro, cuja posição espiritual na Bahia pode-se, talvez, comparar com a de um patriarca, um cardeal.

O Curtiusschüler se sujou de comida na cidade. Ele ficou com a camisa na sua visita em Batefolha. Eu também aprecio camisas sujas de comida e desejaria que se recebessem ditadores e líderes da economia com camisas sujas. Mas 
empfangen. Aber hätte sich der Curtiusschüler nicht doch für einen

\section{Seite 103}

Empfang bei Präsident Medici oder bei Herrn Abs ein frisches Hemd angezogen?!

So tritt der Repräsentant der Kultur des wirtschaftlich potentesten europäischen Landes mit bekleckertem Hemd dem geistlichen Chef der Kongo in Bahia gegenüber, der einen blütenweissen Anzug in der ländlichen Umgebung trägt.

Pedro empfängt uns mit der inm eigenen traurigen Freundlichkeit.

Er ist wohl bereit, uns die Heiligenhäuschen vielleicht die schönsten zweier Kontinente - zu zeigen, aber wir sollten uns erst einen Augenblick hinsetzen, uns ausruhen, etwas plaudern.

Pedro zeigt uns die schwarze Kammer von Xango.

Der Curtiusschüler bemerkt klug, die Sitte, die Schuhe auszuziehen, könnte vom Islam herrühren.

Kaum hat Pedro das heilige Zimmer betreten, flutscht der Curtiusschüler schon hinterher.

In den mystischen Raum für Oxala drängt sich der Curtiusschüler mit dem Kongogeistlichen zusammen durch die Tür und den heiligen Bezirk um den Baum des Gottes Tempo betritt der Curtiusschüler sogar, bevor der Schamane inm den Weg gereinigt hat - hier lauern die Krankheiten und die Toten.

Pedro gibt formelhaft Erklärungen ab:

Er verehrt drei Indianergottheiten.

Kinder weiht er nicht ein. Er bereitet sie auf die spätere Einweihung vor. Kinder sollen in die o Curtiusschüler não teria vestido uma camisa limpa para

\section{Página 103}

uma recepção com o Presidente Medici ou com o Senhor Abs?!

Assim, o representante da cultura do país europeu economicamente mais potente pôs-se defronte do chefe espiritual do Kongo na Bahia, que veste um terno branco-florescente nos arredores campestres, de camisa suja.

Pedro nos recebe com a triste amabilidade que Ihe é peculiar.

Ele está bastante disposto a nos mostrar as casinhas sagradas - talvez as mais belas de dois continentes - mas nós devemos primeiro nos sentar por um instante, descansarmos, conversarmos um pouco.

Pedro nos mostra o quarto negro de Xangô.

O Curtiusschüler observa sagazmente que 0 costume de tirar os sapatos poderia se originar do Islã.

Pedro mal pisou no quarto sagrado, o Curtiusschüler já desliza atrás.

Ao quarto místico para Oxalá, o Curtiusschüler se apinha com o sacerdote do Kongo pela porta e o território sagrado em torno da árvore do deus Tempo, o Curtiusschüler pisa até antes que o xamã lhe limpe o caminho - aqui ficam à espreita as doenças e os mortos.

Pedro dá explicações formais:

Ele venera três divindades indígenas.

Crianças, ele não inicia. Ele as prepara para uma iniciação mais tarde. Crianças devem ir à escola 
Schule gehen und nicht sechs Monate in einer Einweihungszelle hocken.

- Es ist besser, nicht zu zwingen, sagt Pedro.

Pedro geleitet den Gast aus der Bundesrepublik an die Pforte - eine Ehrenbezeigung, die er seinen geistlichen Töchtern, den Ogas, wohlhabenden Patienten nicht erweisen würde.

Pedro wartet, bis wir ins Auto gestiegen sind und abfahren. Aber wir fahren nicht ab.

Der Curtiusschüler muss mal. Er steigt wieder aus und geht zwanzig Meter weiter und schifft.

Pedro wartet, bis der Europäer zu Ende geschifft hat, und wünscht uns bei der Abfahrt eine gute Reise.

Während der Rückfahrt bemerkt der Curtiusschüler, von komplizierten, geistigen Strukturen bei den Negern zu sprechen, sei wohl etwas übertriebenen, sonst würden die Neger doch nicht dauernd ihre Sitten und Gebräuche wechseln.

\section{Seite 104}

Pedro gibt ein Essen für den Götterboten Exu, um die Wege zu säubern.

Drei Autos vor der Pforte.

Einige Privatleute. Töchter. Ogas.

In der Nähe einer Palmgruppe werden Fleischstücke geröstet.

An der Mauer des Häuschens von Exu hängt ein frischgespanntes Fell.

Das Fleisch wird mit rotem Öl übergossen und in gelbem Mehl gewendet und in das Haus von Exu gebracht. Dort stehen schon andre, mit schwarzen Federn verzierte Opfergaben, auch Zuckerrohrschnaps. Eines der Gerichte ist mit einer transparenten Haut überspannt vielleicht mit der Harnblase des Opfertieres. e não se alapar seis meses em uma cela de iniciação.

- É melhor não forçar, diz Pedro.

Pedro acompanha o visitante da República Federal até o portão - um sinal de honra, que ele não conferiria a suas filhas espirituais, aos ogãs, a pacientes abastados.

Pedro espera até que nós tenhamos embarcado no carro e partido. Mas nós não partimos.

O Curtiusschüler tem que ir ao banheiro. Ele desembarca novamente e anda vinte metros para frente e mija.

Pedro espera até que o europeu tenha terminado de mijar e deseja-nos na partida uma boa viagem.

Durante a viagem de volta, o Curtiusschüler observa que falar de estruturas complexas, espirituais nos negros seria um tanto exagerado, senão os negros não mudariam constantemente seus usos e costumes.

\section{Página 104}

Pedro dá uma comida ao mensageiro dos deuses Exú, para limpar os caminhos.

Três carros diante do portão.

Alguns particulares. Filhas. Ogãs.

$\mathrm{Na}$ proximidade de um grupo de palmeiras pedaços de carne são grelhados.

No muro da casinha de Exú está pendurada uma pele recém-esticada.

A carne é regada com óleo vermelho e passada em farinha amarela e levada para a casa de Exú. Lá estão outras oferendas enfeitadas com penas pretas, também aguardente de cana. Uma das comidas está esticada com uma pele transparente - talvez com a bexiga de um animal de sacrifício. 
Zwei Trommler trommeln.

Abebbendes Händeklatschen.

Die Gläubigen haben sich Cajublätter gepflückt und nehmen damit Fleisch und Mehl in Empfang. Jeder Knochen und jedes Blatt wird sorgfältig eingesammelt. Ich habe nach dem Essen mein Blatt weggeschmissen. Aber schnell hat es einer aufgesammelt und zu den anderen in eine grosse Kalebasse getan.

Trommeln. Agogo. Tänze.

Eine der Töchter tanzt nach vorn und bringt Pedro einen Teil der Schädelknochen.

Die Pequena Mãe bringt ein einzelnes Knöchelchen.

Wilde, komplizierte Tänze.

Pedro endet seine Ansprache mit einem Hinweis auf Jesus Christus.

- Die Wege sind nun sauber.

Eine Würdenträgerin sagt:

- Ist das schon das Ende des Candomblé?

Jetzt geht es erst richtig los.

Pedro hat im Fenster des Hauses von Exu einen Teller mit Fleisch und gelbgefärbten Mehl stehen lassen, den nimmt er jetzt und stellt inn auf die Umfriedung des Baumes von Tempo.

Pedro ist heute sehr Pai de Santo. Er antwortet nur ungern.

Es gebe einen Exu der Pforte und einen mitten auf dem Gelände, der die Wege säubert, und einen dritten im Wald.

Ich gehe bis Cabula durch die Nacht zu Fuss.

An den Kreuzwegen flackern die Kerzen von den Opfertellern für Exu, die Unheil bringen sollen.
Dois tocadores de tambor tocam.

Batidas de palma enfraquecidas.

Os fiéis colheram folhas de caju e, com ela, recebem carne e farinha. Cada osso e cada folha são recolhidos cuidadosamente. Eu joguei minha folha fora depois da comida. Mas rapidamente alguém a apanhou e entregou aos outros em uma grande cabaça.

Tambores. Agogô. Danças.

Uma das filhas dança para frente e leva para Pedro uma parte dos osso do crânio.

A Pequena Mãe traz um único ossinho.

Danças selvagens, complicadas.

Pedro termina seu discurso com uma menção a Jesus Cristo.

- Os caminhos estão limpos agora.

Uma dignitária diz:

- Já acabou o candomblé?

Agora é que começou mesmo.

Pedro deixou na janela da casa de Exú um prato com carne e farinha amarelada, agora ele o pega e coloca nas cercanias da árvore do Tempo.

Pedro está hoje muito Pai de Santo. Ele só responde de má vontade.

Haveria um Exú da Porteira e um - no meio da Estrada, que limpa os caminhos, e um terceiro na mata.

Eu vou até Cabula durante a noite a pé.

Nas encruzilhadas as velas bruxuleiam diante dos pratos de sacrifício para Exú, que devem trazer desgraça. 
Insekten fliegen mir nach und rasseln über meinen Kopf.

\section{Seite 105}

Die Mannschaftswagen der Militärpolizei fahren durch die Stadt. Auf den Bänken jeweils etwa 50 Polizisten in frisch gebügelten Uniformen mit Maschinenpistolen.

Sympathische, wohlgenährte Afrikaner.

Sie wurden im Elend geboren und es gab für sie nur eine Alternative:

Verbrecher oder Polizist.

Was sind diese kindlichen, sexigen jungen Männer nicht alles bereit zu begehen?

Sie besetzen das Gerichtsmedizinische Institut "Nina Rodrigues《.

Militärpolizisten gucken aus jedem Fenster.

Militärpolizisten versperren die Treppe, wo sonst die weinenden Hinterbliebenen stehen.

Haben die Leichen in den Kühlschränken eine Revolte begonnen?

Haben die Leichenwäscher revoltiert?

Oder sind Leichen eingeliefert worden, deren Zustand nicht bekannt werden darf?

Sonnabend, den 18. September:

A Tarde:

Lamarca stirbt im Staate Bahia.

Die Geliebte des Exhauptmanns lara lavelberg beging in einer Wohnung in Pituba Selbstmord, als die Polizei vor einem Monat das Haus stürmte. Ihre Leiche blieb mehrere Tage in der Morgue - "Nina Rodrigues « -, da man hoffte, dass ihre Liebhaber, der Terrorist Lamarca, versuchen würde, ihrer habhaft zu werden.
Insetos voam atrás de mim e zunem sobre minha cabeça.

\section{Página 105}

Viaturas de transporte da polícia militar andam pela cidade. Nos bancos, cerca de 50 policiais em uniformes recentemente passados, com pistolas-metralhadoras.

Africanos simpáticos, bem alimentados.

Eles nasceram na miséria e só havia para eles uma alternativa:

Criminoso ou policial.

O que esses homens jovens, sexys, infantis não estão dispostos a cometer?

Eles ocupam o Instituto de Medicina Legal "Nina Rodrigues".

Policiais militares olham pela janela.

Policiais militares bloqueiam a escada onde normalmente ficam os familiares deixados para trás chorando.

Os cadáveres nas geladeiras começaram uma revolta?

Os que lavam os cadáveres se revoltaram?

Ou foram entregues cadáveres, cujo estado não deve ser divulgado?

***

Sábado, 18 de setembro:

A Tarde:

Lamarca morre no Estado da Bahia.

A amante do ex-capitão, lara lavelberg, comete suicídio em um apartamento em Pituba, quando a polícia invadiu a casa há um mês. Seu cadável ficou vários dias no necrotério - "Nina Rodrigues" - pois esperava-se que seu amante, o terrorista Lamarca, tentaria se apossar dele. 
Der Terroristenchef Lamarca wurde gestern niedergemacht.

Hunderte werden verhaftet, gefoltert.

Nach ihren Aussagen werden weitere Hunderte verhaftet, gefoltert. Es ist gleichgültig, ob sie zum Widerstand gehören oder nicht. Kinder, Schüler, Studenten, Lehrer, Bauern, Arbeiter.

Es wird täglich in mehreren Kasernen gefoltert.

Die Instrumente werden täglich von einer Kaserne zur anderen transportiert.

Soldaten und Polizisten werden im Foltern ausgebildet.

\section{Seite 106}

Während der Folter sind Ärzte anwesend, die den Opfern den Puls fühlen und entscheiden, ob man weitermachen kann, ohne den Tod des Gefangenen zu riskieren.

Die politischen Gefangenen berichten bei den Verhandlungen von den Foltern, denen sie ausgesetzt waren.

Die Presse ist nicht mehr in der Lage, über die im ganzen Land, in jeder Stadt täglich begangenen Foltern zu berichten.

In Bahia werden den Gefangenen - Männer und Frauen - Drähte in die Harnwege eingeführt, über die man elektrische Schocks auslöst.

Der Exhauptmann Carlos Lamarca, der am 24. Januar 1969 mit einer Wagenladung Waffen seine Kaserne verliess und den Guerillakampf gegen das Militärregime Brasiliens anführte, wurde mit 33 Jahren im Staate Bahia getötet. Angeblich wurde er im Kampf erschossen.

Sonntag, den 19. September:
O chefe terrorista Lamarca foi abatido ontem. $\star \star \star *$

Centenas são presos, torturados.

Segundo suas declarações, outras centenas são presas, torturadas. É indiferente se eles pertencem à resistência ou não. Crianças, alunos da escola, estudantes universitários, professores, camponeses, trabalhadores.

Tortura-se diariamente, em diversas casernas.

Os instrumentos são transportados diariamente de uma caserna a outra.

Soldados e policiais são treinados em tortura.

\section{Página 106}

Durante as torturas estão presentes médicos que sentem o pulso das vítimas e decidem se pode dar continuidade, sem arriscar a morte do prisioneiro.

Os prisioneiros politicos relatam nas audiências sobre as torturas a que foram submetidos.

A imprensa não está mais em condições de noticiar sobre as torturas cometidas em todo o país, em toda cidade diariamente.

$\mathrm{Na}$ Bahia, são introduzidos nos prisioneiros homens e mulheres - arames nas vias urinárias, pelas quais se disparam choques elétricos.

O ex-capitão Carlos Lamarca, que deixou sua caserna em 24 de janeiro de 1969 com um carregamento de armas e liderou uma luta de guerilha contra o regime militar do Brasil, foi morto aos 33 anos no Estado da Bahia. Supostamente, foi morto a tiros em luta. ***

Domingo, 19 de setembro: 
Jornal da Bahia:

Im August hatte sich die Geliebte des Exhauptmanns lara lavelberg in ihrer Wohnung erschossen. Sie vertraute ihren Freunden an, dass sie nicht wüsste, ob sie einem Verhör durch die Polizei gewachsen sei.

Dem Jornal da Bahia ist es gelungen, einen Reporter in das Gerichtsmedizinische Institut »Nina Rodrigues « zu schleusen:

Der Körper Lamarcas zeigt die Einschlaglöcher von vier Dumdumgeschossen, die beim Auftreffen explodierten. In der rechten Achsel, im rechten Arm und in der linken Hand. In der Leiste ein weiterer Einschuss. Die abgerissenen Glieder der linken Mittel- und Zeigefinger liegen auf dem halbzerstückten Geschlechtsteil. Der Mund Lamarcas hat am Oberkiefer keine Zähne mehr. Unten fehlen die Schneidezähne. An der rechten Gesichtshälfte Hämatome.

Dem »Jornal da Bahia « ist es gelungen, einen Text zu veröffentlichen, den man so lesen kann und so.

Eine Übersetzung verdeutlicht das, was jeder Leser las; es ist ein brasilianischer Text, den die Militärregierung nicht verbieten konnte.

\section{Seite 107}

Im Gerichtsmedizinischen Institut sagt uns João:

- Wir arbeiten Tag und Nacht!

Es ist ein harter Beruf. Ich kann sie nicht fotografieren lassen. Ein Fotograf, der die Leiche Lamarcas fotografiert hat, sitzt im Gefängnis. Die Armee hat 300 Fotografien von Lamarcas Leiche hergestellt und an die Presse verteilt.

João holt den Totenschein von Lamarca.
Jornal da Bahia:

Em agosto, a amante do ex-capitão, lara lavelberg, atirou em si mesma em seu apartamento. Ela confidenciou a seus amigos que não sabia se estava à altura de um interrogatório da polícia.

Jornal da Bahia conseguiu introduzir às escondidas um repórter no Instituto de Medicina Legal "Nina Rodrigues":

O corpo de Lamarca mostra os buracos do impacto de quatro balas dundum, que explodiram no choque. No ombro direito, no braço direito e na mão esquerda. Na virilha, um outro buraco de bala. As articulações arrancadas dos dedos médio e indicador estão sobre o órgão sexual meio retalhado. A boca de Lamarca não tem mais dentes no maxilar superior. Em baixo faltam os dentes incisivos. Na metade direita do rosto, hematomas.

***

O "Jornal da Bahia" conseguiu publicar um texto que se pode ler assim e assim.

Uma tradução esclarece o que cada leitor leu; é um texto brasileiro que o governo militar não pôde proibir.

\section{Página 107}

No Instituto de Medicina Legal, João nos diz:

- Nós trabalhamos dia e noite!

É uma profissão dura. Eu não posso mandar fotografá-la. Um fotógrafo que fotografou o cadáver de Lamarca está na prisão. O exército produziu 300 fotografias do cadáver de Lamarca e distribui-as à imprensa.

João busca a certidão de óbito de Lamarca. 
Es sind blutige Fingerabdrücke darauf.

João weint. Es liest den Totenschein noch einmal laut vor.

Montag, den 20. September:

Tribuna da Bahia:

Die Regierung des Bundesstaates Bahia wusste noch nicht, dass noch immer 600 Familien seit der Regenkatastrophe im April auf der Strasse leben.

Fünf Kinder starben bereits. Die Familien hunger. Die Häuser der meisten wurden von der Präfektur niedergerissen. Man vertröstete sie. Einer der Obdachlosen, João Bispo dos Santos, arbeitet bei der Stadtreinigung. Er verdient den Salario Minimo. Er hat acht Kinder. Auch sein Haus wurde von der Präfektur niedergerissen. Nachts kann die Familie in ihrem Unterschlupf vor Insekten und Gestank nicht schlafen.

Es wird Abend, als ich in Batefolha ankomme.

Die Frauen bereiten mit langsamen, sicheren Bewegungen das Essen.

Sie rufen die Kinder zum zweiten Bad.

Pedro heilt einen Kranken in der Umfriedung für Tempo.

Aber heute hat er keine Blätterbüschel, sondern er tastet mit einem weissen Hahn den Patienten ab.

Julio sagt mir, der weisse Hahn würde später von dem Kranken unter den Füssen erstickt.

Der Stellvertreter Pedros erzählt mir, dass es schwierig geworden ist, die heiligen Ingredienzen aus Afrika zu bekommen.
Há impressões digitais sangrentas nela.

João chora. Ele lê a certidão de óbito novamente em voz alta.

$\star \star *$

Segunda-feira, 20 de setembro:

Tribuna da Bahia:

O governo do Estado da Bahia ainda não sabia que 600 famílias ainda vivem na rua desde a catástrofe da chuva em abril.

Cinco crianças já morreram. As famílias estão passando fome. As casas da maioria foram demolidas pela prefeitura. Elas são consoladas. Um dos sem-teto, João Bispo dos Santos, trabalha na limpeza municipal. Ele ganha o Salario Minimo*. Ele tem oito filhos. Também sua casa foi demolida pela prefeitura. À noite, a família não pode dormir em seu abrigo devido a insetos e ao fedor.

***

Anoitece quando eu chego a Batefolha.

As mulheres preparam a comida, com movimentos vagarosos e seguros.

Elas chamam as crianças para o segundo banho.

Pedro cura um doente nas cercanias do Tempo.

Mas hoje ele não tem nenhum tufo de folhas, e sim ele apalpa o paciente com um galo branco.

Julio me diz que o galo branco seria mais tarde sufocado pelo doente sob os pés.

O substituto de Pedro me conta que ficou difícil receber os ingredientes sagrados da África. 
Früher gab es einen portugiesischen Händler, Cardeal, der die heiligen Waren, Stroh der Küste, braune Seife, Indigo, Bedjere-

\section{Seite 108}

Gumbohnen, Orobonüsse, Colanüsse, Ketten, Kauris, Steine im Hafen von Natal in Empfang nahm und dann die ganze Küste entlangzog, nach Recife, Bahia, Rio.

Aber Cardeal ist schon lange tot.

Mittwoch, den 29. September:

Tribuna da Bahia:

Minister Dias Leite wird auf seiner Reise auch den Vatikan besuchen und dem Papst die Foltern in Brasilien erklären.

\section{Beim Priester Mario:}

Nähmaschine, Television, Warten.

Mario hat Grippe und läßt sich Spritzen geben. Schliesslich holt er unter einem Maskottchen eine heilige Kette hervor und Kaurimuscheln.

Er geht in den Regen hinaus und wirft vor dem Häuschen Exus die Kauris.

\section{Er sagt:}

-Exu wird die Zeremonie stören!

Er breitet in der Küche eine Zeitung (mit Artikeln über Allende) aus, stellt eine brennende Kerze darauf und Teller mit schwarzen Bohnen, weissen Bohnen, mit
Antigamente havia um comerciante português, Cardeal, que recebia a mercadoria sagrada, palha da costa, sabão marrom, Indigo, Bedjere-

\section{Página 108}

Favas de goma, nozes de orobô, nozes de cola, colares, cauris, pedras no Porto de Natal e então ladeou toda a costa, para Recife, Bahia, Rio.

Mas Cardeal já está morto há muito tempo. $* * *$

Quarta-feira, 29 de setembro:

Tribuna da Bahia:

Ministro Dias Leite visitará, em sua viagem, também o Vaticano e explicará ao Papa as torturas no Brasil.

***

Na casa do sacerdote Mario:

Máquina de costura, televisão, espera.

Mario tem gripe e manda que lhe deem injeções.

Por fim, ele retira debaixo de um mascot um colar sagrado e conchas de cauri.

Ele sai na chuva e joga cauris diante da casinha de Exú.

Ele diz:

- Exú vai pertubar a cerimônia!

Ele estica na cozinha um jornal (com artigos sobre Allende), coloca uma vela acesa em cima e pratos com feijões pretos, feijões brancos, com 
Klössen, mit weissem Mehl, mit bräunlichen Erbsen oder Bohne.

Eine ältere, magere Frau wird hereingeführt. Sie muss sich zwischen die Opfergaben auf die Zeitung stellen.

Mario wirft ihr die Kauris ihr zu Füssen.

Ein Junge nimmt beide Hände voll Puffmais und fährt damit an ihrem Körper entlang. Er wirft den Puffmais vor ihr auf die Zeitung. Das wiederholt er mehrmals. Dann giesst er ein ganzes silbriges Sieb mit Puffmais über ihr aus.

Er fährt mit einer Opfergabe nach der anderen an inrem Körper entlang, besonders über den Unterleib.

Mario schneidet das ärmliche Kleid der Frau ein, nachdem er sich erkundigt hat, ob sie es entbehren könnte. Er reisst es, an den Schultern beginnend, rundherum in Fetzen, reisst es schliesslich auseinander und wirft es ihr vor die Füsse.

Sie steht jetzt in einem povren Unterkleid da ..

Sie soll sich die »Füsse reinigen «, das heisst, den Puffmais und die

\section{Seite 109}

Bohnen wegtrampeln. Alles wird in die Zeitung gerollt. Sie soll das Unheil zur Tür hinausschleudern. Mario zeigt ihr die das Unheil wegschleudernde Geste.

Mario bestimmt, an welchem Kreuzweg das Paket abgelegt werden soll.

Der Junge muss damit in den Regen hinaus.

Mario erklärt uns:

Das war ein Despacho für Exu. Die Frau hat eine Krankheit, die nur Exu heilen kann.

Donnerstag, den 7. Oktober: bolinhos de massa, com farinha branca, com ervilhas acastanhadas ou feijão.

Uma mulher idosa, magra, é conduzida para dentro. Ela tem que se colocar entre as oferendas sobre o jornal.

Mario joga os cauris aos pés dela.

Um menino traz duas mãos cheias de pipoca e passa-as ao longo do corpo dela. Ele joga a pipoca diante dela sobre o jornal. Isso ele repete várias vezes. Então ele derrama toda uma peneira prateada com pipoca sobre ela.

Ele passa uma oferenda após outra no corpo dela, especialmente no baixo-ventre.

Mario deu um talho no vestido empobrecido da mulher, depois que ele se informou se ela poderia dispensá-lo. Ele o rasga, começando pelos ombros, todo em farrapos, por fim separao e joga-o diante de seus pés.

Ela está agora ali em pé, numa pobre combinação ..

Ela deve "lavar os pés", isso significa, pisotear a pipoca e

\section{Página 109}

os feijões. Tudo é enrolado no jornal. Ela deve atirar fora a desgraça pela porta. Mario mostra a ela os gestos de atirar a desgraça para fora.

Mario determina em que encruzilhada o pacote deve ser depositado.

O menino tem que sair com ele na chuva.

Mario nos explica:

Isso foi um Despacho para Exu. A mulher tem uma doença que só Exu pode curar.

***

Quinta-feira, 7 de outubro: 
Jornal da Bahia:

In der neuen Siedlung Pau de Lima fehlen Wasser, Licht und Ordnungshüter. Den Einwohnern wird von den Sozialhelferinnen verboten, mit Besuchern über ihre Probleme zu sprechen.

\section{Zu Pedro nach Batefolha.}

Alles blüht.

Der Stellvertreter empfängt mich freundlich. $\mathrm{Er}$ ist verblüfft, dass ich inm echte, afrikanische Bedjeregumbohnen mitbringe.

Er lobt die Grösse der Bohnen. Wozu sie angewendet werden, sagt er nicht. Aber sie kämen nicht in den Abó, den Einweihungstrank.

Der Stellvertreter schenkt mir ein Colabäumchen und sagt, ich könnte jederzeit von inm Colanüsse für meine Freunde bekommen.

Pedro holt eine Tonschale, in der ein kleines Colawäldchen wächst.

Der Stellvertreter hört sich meine Pflanzenliste für den Abó des Gottes Xango an. Er meint, es fehlten wohl keine, aber einige seien überflüssig. Welche, das dürfe er nicht sagen.

Batefolha hat einen Oga, der sich nur um die heiligen Pflanzen kümmert. Im übrigen bestimmte der Pai de Santo, Pedro, über alles, was die Einweihungsgetränke angeht.

Als ich gehe, packt mir die Pequena Mãe noch den Ableger einer hübschen, dickblättrigen Pflanze ein.

Den Namen haben plötzlich alle vergessen. Schliesslich nennt mir der Stellvertreter den Falschen: Folha da Costa. -

\section{Seite 110}

Jornal da Bahia:

No novo assentamento Pau de Lima falta água, luz e guardiões da ordem. Os habitantes são proibidos pela assistente social de falar sobre seus problemas com visitantes.

***

Para Pedro, ao Batefolha.

Tudo floresce.

O substituto me recebe amigavelmente. Ele está pasmo que eu lhe traga feijões Bedjere verdadeiros, africanos.

Ele elogia o tamanho dos feijões. Para que são utilizados, ele não diz. Mas eles não entram no Abó, na bebida de iniciação.

O representante me presenteia com uma arvorezinha de cola e diz que eu poderia a qualquer momento obter dele nozes-de-cola para meus amigos.

Pedro apanha uma tigela de barro, na qual cresce uma pequena mata de cola.

O substituto escuta minha lista de plantas para o Abó do deus Xangô. Ele acha que não falta provavelmente nenhuma, mas algumas seriam supérfluas. Quais, isso ele não teria permissão para dizer.

Batefolha tem um ogã que só cuida das plantas sagradas. De resto, o Pai de Santo, Pedro, determina tudo que diz respeito às bebidas de iniciação.

Quando eu vou embora, a Pequena Mãe embrulha para mim ainda o ramo de uma bonita planta de folhagem espessa.

Do nome, de repente todos se esquecem. Por fim, o substituto me dá o errado: Folha da Costa*. -

\section{Página 110}


Nicht den Falschen, den nicht ganz Richtigen, den einer nahe verwandten Pflanze. Der Pequena Mãe missfällt diese Lüge. Sie nennt mir den Richtigen: Milagre de São Joaquim.

Sonntag, den 10. Oktober:

Jornal da Bahia:

Vier Familien - 22 Personen - wurden aus dem Sportclub von Bahia gewiesen, wo sie seit der Regenkatastrophe im April Unterkunft gefunden hatten.

Ihnen wurde mitgeteilt, dass sie kein Anrecht auf ein neues Haus hätten. Die Behörde liess sie nach der Ausweisung stundenlang in der Stadt herumfahren und lud sie schliesslich in der neuen Siedlung Pau de Lima ab, wo sie sich im Freien zwischen den anderen Häusern eingerichtet haben.

Die Busfahrer veranstalten auf den engen Strassen Wettrennen.

Unfälle mit vier Toten.

Die vollbesetzten Busse überfahren Fussgänger und fahren davon, ohne das seiner den Chauffeur anzeigte.

Ein alter, von Arbeit zerschundener Mann steht mit zwei Säcken im Bus.

Er klingelt, um auszusteigen.

Beim Stop bückt er sich und will die Säcke hochnehmen.

Der Bus fährt schon weiter.

Der Mann protestiert.

Aber der Chauffeur hält erst wieder nach zwei Kilometern und der alte Mann muss mit den beiden schweren Säcken abends um acht, nach der Arbeit, die beiden Kilometer zurückgehen.
Não o errado, o não muito certo, o de uma planta de parentesco próximo. À Pequena Mãe* desagrada essa mentira. Ela me dá o certo: Milagre de São Joaquim.

$* \star \star$

Domingo, 10 de outubro:

Jornal da Bahia:

Quatro famílias - 22 pessoas - foram expulsos do Sportclub da Bahia, onde eles, desde a catástrofe das chuvas, haviam encontrado abrigo.

Foi-Ihes informado que elas não teriam direito a uma nova casa. A autoridade deixou-as andar de carro pela cidade horas a fio após a expulsão e, por fim, descarregou-as no novo assentamento Pau de Lima, onde elas se instalaram ao ar livre entre as outras casas.

Os motoristas de ônibus organizam competição de corrida nas ruas estreitas.

Acidentes com quatro mortos.

Os ônibus lotados atropelam os pedestres e fogem, sem que alguém denuncie o chauffeur.

Um homem velho, lacerado pelo trabalho, está em pé com dois sacos no ônibus.

Ele dá o sinal para desembarcar.

Na parada ele se abaixa e que levanter os dois sacos.

O ônibus segue viagem.

O homem protesta.

Mas o chauffeur só para novamente dois quilômetros depois e o velho homem tem que voltar os dois quilômetros com os dois sacos pesados, à noite, às oito, depois do trabalho. 
Pedro ist beschäftigt.

-Darf ich allein durch den Wald gehen? -Ja.

Ich lasse das bekannte Wohnhaus zurück, das langgestreckte Versammlungsgebäude, die Häuschen für die Götter, den heiligen Baum des Gottes Tempo.

Urwald. Insekten.

Die unheimliche Mittagsstunde.

Knacken.

\section{Seite 111}

Geklapper.

Vor mir. Jetzt hinter mir. Fern. Nah.

Wer folgt mir? Welches Tier kreist mich ein, knarrt mich an mit seinen Zangen, Flügeln?

Ich komme an ein Lehmhaus. Es ist abgeschlossen. Ich sehe durch die Ritzen der Tür.

Vasen drinnen. Weisse Vasen mit weissen Schärpen.

Ist es das Haus der Toten?

***

Der Taxifahrer, der aus Recife stammt, sagt:

- Hier in Salvador hilft keiner dem anderen. Hier zerstört einer den anderen.

Fenster und Türen verrammelt.

Die geistlichen Töchter Pedros huschen herum ohne zu grüssen.

Der Stellvertreter kommt mit Augen, in deren Weiss die Äderchen geplazt sind.

-Wie geht es?
Pedro está ocupado:

- Posso andar sozinho pela mata?

- Sim.

Eu deixo para trás a conhecida residência, o prédio de reuniões alongado, as casinhas para os deuses, a árvore sagrada do deus Tempo.

Mata nativa. Insetos.

A assustadora hora do meio-dia.

Crepitar.

\section{Página 111}

Estalos.

Na minha frente. Agora atrás de mim. Longe. Perto.

Quem está me seguindo? Que animal me cerca, rangendo para mim com suas garras, asas?

Eu chego a uma casa de pau-a-pique. Ela está fechada. Eu olho pelas frestas da porta.

Vasos lá dentro. Vasos brancos com faixas brancas.

É a casa dos mortos?

$* * *$

O motorista de táxi que provém de Recife, diz:

- Aqui em Salvador ninguém ajuda o outro. Aqui um destrói o outro.

***

Janelas e portas barricadas.

As filhas espirituais de Pedro borboleteiam por ali, sem cumprimentar.

O substituto chega com olhos, em cujo branco as veiazinhas estão estouradas.

- Como vai? 
- Einigermassen.

- Pedro wollte heute mit mir sprechen.

- Ja.

- Ist er noch nicht gekommen?

- Ich habe eine Nachricht für Sie.

- Was für eine?

- Pedro ist tot.

- Pedro ist tot.

Vor seinem Wohnhaus in der Stadt stritten sich zwei Männer. Pedro ging hinaus und versuchte sie zu besänftigen.

Einer nahm einen Holzknüppel und schlug den feingebildeten Schädel von Pedro kaput. Er starb wenig später. Einen Tag darauf wurde er begraben.

Nichts ist mehr von inm da, als ein paar Kultgewänder, die bei seinem Axexe ins Meer gesenkt werden.

Seine Stimme auf den heimlich laufenden Tonbändern.

Bahia de Todos os Santos.

Hier gibt der Mensch nichts.

Bestenfalls das Geld, das er besitzt.

Pedros Schädel zertrümmern!

\section{Seite 112}

Die Blüten, die Heiligenhäuschen, die roten Augen des Stellvertreters, des ewigen Stellvertreters, fangen an zu zittern.

Güte hat hier keinen Platz - muss weg.

Ich will mich nicht trösten lassen.

Ich beobachte die Wörter und den Gesichtsaudruck des Stellvertreters: Pedro ist schon der tote, gefürchtete Feind geworden, gegen den man Türen und Fenster
- Mais ou menos.

- Pedro queria falar comigo hoje.

- Sim.

- Ele ainda não chegou?

- Eu tenho uma notícia para o senhor.

- Qual?

- Pedro está morto.

- Pedro está morto.

$\mathrm{Na}$ frente de sua residência na cidade, dois homens brigaram. Pedro saiu e tentou apaziguálos.

Um deles pegou um cassetete de madeira e rompeu o crânio de Pedro, delicadamente formado. Ele morreu um pouco mais tarde. Um dia depois, ele foi enterrado.

Não existe nada mais dele ali do que algumas roupas do culto, que no seu Axexê serão afundadas no mar.

Sua voz nas fitas rodando às escondidas.

Bahia de Todos os Santos.

Aqui o ser humano não é nada.

No melhor dos casos, o dinheiro que ele possui.

Esmagar o crânio de Pedro!

\section{Página 112}

As flores, as casinhas sagradas, os olhos vermelhos do substituto, do eterno substituto, começam a tremer.

O bem não tem lugar aqui - tenho que ir embora.

Eu não quero me deixar consolar.

Eu observo as palavras e a expressão facial do substituto: Pedro já se transformou no inimigo morto temido, contra o qual se obstruem portas e janelas, que finalmelnte desocupou a poltrona do sacerdote perigosamente. 
verrammelt, der endlich, gefährlich den Priestersessel geräumt hat.

Ich gehe durch die armseligen Siedlungen im Urwald, im Lautsprecherlärm zurück.

Ich glaube nicht, dass Pedro und sein Glaube die Armen von ihrem Elend befreit hat, aber seine Intensität und seine Behutsamkeit machten das Elend leichter erträglich - für die Elenden leichter erträglich.

Er hatte zwei Kinder adoptiert und dafür gesorgt, dass die Kinder der Nachbarschaft eine rudimentäre Schulbildung erhielten.

Die Bahianer lieben den Fremden nicht.

Für die Afrikaner ist der Fremde der, der übers Meer kam, plünderte, Familien zerriss, die Schwächeren erschlug, die Kräftigeren brandmarkte und auf Schiffe pferchte.

Für die Weissen, die Herren von Bahia, sind die Fremden diese Afrikaner, die hasserfüllt, abgemagert, von Krankheiten zerfressen, käuflich und verkaufbar ankamen, zur Arbeit genötigt, ausgenützt, abgenützt, ausgelöscht, gefährlich und gefürchtet.

In Bahia ist - trotz der kitschigen Kruste, an der sogar die Intellektuellen mitrösten - der Mensch durch Zahlen abgebildet worden. Das ausgestochene Auge des Sklaven bedeutete die und die Wertminderung eines investierten Kapitals, ein gewaltiges und oft erregbares Glied den und den Gewinnzuwachs in Gestalt von verscheuerbaren Nachkommen.

Wilhelm ist Ingenieur. Er erzählt von einem Menschenopfer:

-In der Baixa do Tubo gibt es vielleicht hundert kleine Cadomblés. Früher wagte sich nicht einmal die Polizei da hinein. Die Leute pflanzten Marihuana in ihren Hausgärten an.
Eu volto pelos miseráveis assentamentos na mata nativa, ao barulho de alto-falantes.

Eu não acredito que Pedro e sua crença tenham libertado os pobres de sua miséria, mas sua intensidade e seu cuidado deixaram a miséria mais fácil de suportar - para os miseráveis mais fácil de suportar.

Ele havia adotado duas crianças e providenciado que as crianças da vizinhança recebessen uma formação escolar rudimentar.

***

Os Bahianos não gostam do estrangeiro.

Para os africanos, o estrangeiro é aquele que veio pelo mar, saqueou, despedaçou famílias, matou os mais fracos, marcou os mais fortes a ferro quente e os encurralou em navios.

Para os brancos, os senhores da Bahia, os estrangeiros são esses africanos que chegaram cheios de ódio, emagrecidos, corroídos por doenças, compráveis e vendáveis, forçados ao trabalho, explorados, desgastados, aniquilados, perigosos e temidos.

Na Bahia - apesar da crosta kitsch, na qual até os intelectuais se tostam - o ser humano é representado por números. O olho arrancado do escravo significa essa ou aquela redução de valor de um capital investido, um membro enorme e frequentemente excitável esse ou aquele crescimento nos lucros em forma de descendência vendável a preço baixo. $\star * *$

Wilhelm é engenheiro. Ele conta sobre um sacrifício humano:

- Na Baixa do Tubo há talvez centenas de pequenos candomblés. Antigamente nem a polícia ousava entrar lá. As pessoas plantavam Marihuana em seus jardins caseiros. Quando o 
Als das Katasteramt dort Erhebungen anstellen wollte, wurde ich gefragt,

\section{Seite 113}

ob ich mich hinuntertrauen würde. Ich habe zugesagt. Zuerst sahen mich die Leute finster an und ich fürchtete, jeden Augenblick ein Messer zwischen die Rippen zu bekommen. Aber allmählich gewöhnen sie sich an mich und ich habe noch immer einige Freunde dort.

68 wurde was gemunkelt von einer grossen Arbeit, die der Gott Ogum gefordert hätte. »Grosse Arbeit « kam mir komisch vor. Ich ging also bei meinen Bekannten rum und fing an, nach dem nächsten Fest von Ogum zu fragen. In der Baixa do Tubo liegen fast nur Candomblés, die Ogum geweiht sind. Ich kriegte nichts raus. Einer meiner Bekannten hatte Trouble wegen seines Autos. Ich sagte, ich würde ihm helfen, wenn er mir sagen könnte, wann und wo das Fest für Ogum stattfinden sollte. Erst wollte er nicht. Schliesslich zeigte er mir einen kleinen Candomblé und nannte mir das Datum für das Fest.

Ich komme abends hin. Nur Männer, die mich so ansehen, dass ich es mit der Angst kriege und nicht mehr glaube, da wieder lebendig rauszukommen.

Mein Bekannter stellt mich einem Bekannten vor. Der geht mit mir weg und führt mich stundenlang spazieren. Wir sprechen vom Wetter und so weiter. Mit einem Mal sagt er: »Wollen Sie die Arbeit für Ogum sehen? « Er stösst eine Tür auf. Da liegt die Leiche eines etwa 14jährigen Jungen. Das Gesicht unter einem Lappen. Von den Hüften abwärts alles voller Opfertiere. Nur die Brust ist unbedeckt. Rechts und links am Brustkorb tiefe Einschnitte. Wie haben sie den Jungen getötet? Vergiftet? Kastriert? Oder durch einen Schnitt an der Gurgel? Ich war so aufgeregt und es dauerte nur einen Augenblick und die Tür war wieder zu und dann achtete ich vor cartório de registro de imóveis quis fazer um levantamento, me perguntaram

\section{Página 113}

se eu me atreveria a descer. Eu aceitei. Primeiro as pessoas me olharam de forma soturna e eu temi, a cada piscar de olhos, receber uma faca entre as costelas. Mas, paulatinamente, eles se acostumaram comigo e eu ainda tenho alguns amigos lá.

Em 68 correram alguns rumores de um trabalho grande que o deus Ogum teria exigido. "Trabalho grande" me pareceu estranho. Eu circulei entre os meus conhecidos e comecei a perguntar sobre a próxima festa para Ogum. Na Baixa do Tubo há quase somente candomblés que são consagrados a Ogum. Eu não descobri nada. Um dos meus conhecidos havia tido problema por causa de seu carro. Eu disse que lhe ajudaria, se ele pudesse me dizer quando e onde deveria ocorrer a festa para Ogum. Primeiro, ele não queria. Por fim, ele me mostrou um pequeno candomblé e me indicou a data da festa.

Eu chego lá à noite. Somente homens que me olham de tal forma que eu fico com medo e não acredito mais que saia dali novamente vivo.

Meu conhecido me apresenta a um conhecido. Ele sai comigo e me leva para passear durante horas. Nós falamos sobre o tempo e assim por diante. De repente ele diz: "O Senhor quer ver o trabalho para Ogum?" Ele abre uma porta empurrando. Lá está deitado um cadáver de um menino de 14 anos. O rosto sob um pano. Do quadril para baixo, tudo cheio de animais de sacrifício. Só o peito está descoberto. À direita e à esquerda da caixa toráxica, cortes profundos. Como eles mataram o menino? Envenenado? Castrado? Ou com um corte na garganta? Eu estava tão nervoso e durou apenas um piscar de olhos e a porta estava fechada novamente e então eu tomei cuidado principalmente para que 
allem darauf, selbst wieder lebend da rauszukommen. Ich hatte gehört, dass Ogum nicht nur eine grosse Arbeit verlangt hatte, sonder auch: Das Opfer musste in einer belebten Favela morgens auf die Strasse gelegt werden. Ich bin jeden Morgen hin und plötzlich, ich weiß nicht wie, lag der Junge an der Kreuzung - bedeck von Blumen und Opfergaben. Dort hat die Polizei inn gefunden.

Alle Pais und Mães der Umgegend wurden verhört.

Man hat nichts rausbekommen.

Vielleicht hatten die Polizisten selbst Angst vor Ogum.

Zwei Jahre später - Weihnachten 70 - lag an derselben Stelle ein geopferter Säugling.

\section{Seite 114}

Mãe Oya ist neunzig. Sie lebt in einer kleinen Stadt an der Küste. Zu ihren religiösen Festen kommen der Polizeipräfekt und der katholische Pfarrer.

Sie braucht niemanden zu fürchten.

Es wird gemunkelt, sei sei eine lebende Tote. Ihre Seele sei längst auf und davon geflogen.

Mãe Oya lädt uns ein, an allen Einweihungszeremonien teilzunehmen. Sie hat ein Faible für Leonore und erlaubt ihr, das Ganze zu fotografieren.

- Alles?

- Alles.

Pünktlich und skeptisch treffen wir an einem Freitagabend ein.

Alles ist zum letzten Opferfest der Novizen gerichtet. eu próprio saísse dali vivo. Eu tinha ouvido que Ogum não somente havia exigido um grande trabalho, mas também: a vítima tinha que ser colocada pela manhã na rua de uma Favela movimentada. Eu ia até lá toda manhã e, repentinamente, eu não sei como, o menino estava ali na encruzilhada - coberto com flores e ofertas de sacrifício. Lá a polícia o encontrou.

Todos os Pais* e Mães* da redondeza foram interrogados.

Não se descobriu nada.

Talvez os próprios policiais tivessem medo de Ogum.

Dois anos mais tarde - Natal de 70 - jazia no mesmo lugar um bebê sacrificado.

\section{Página 114}

Mãe Oyá tem noventa anos. Ela vive emu ma pequena cidade na costa. Às suas festas religiosas vêm o chefe de polícia e o padre católico.

Ela não precisa temer ninguém.

Correm rumores de que ela seria uma morta viva. Sua alma já teria há muito levantado voo e ido embora.

Mãe Oyá nos convida a participar de todas as cerimônias de iniciação. Ela tem uma Faible por Leonore e lhe permite que fotografe tudo.

- Tudo?

- Tudo.

Pontuais e céticos, nós chegamos numa sextafeira à noite.

Tudo está arranjado para a última festa de sacrifício dos noviços. 
Säuberlich Sand im Heiligtum gestreut, die Hühner an Stühlen und Tischen festgebunden. Die Böcke blöken.

Aber Mãe Oya ist unpässlich. Sie hat Einwände.

- Das Opfer war schon gestern.

- Das Opfer gibt es gar nicht.

- An dem Opfer heute nacht können Sie nicht teilnehmen.

Die Würdenträger des Hauses sind meine Freunde und als ich sage, dass wir doch extra durch die Nacht hergekommen seien, um alles $\mathrm{zu}$ sehen und zu fotografieren, nickt die Gemeinde, um die Priesterin zu überzeugen.

Ich habe kleine Päckchen bereitet: Afrikanische Colanüsse, Orobonüsse, Bedjeregumbohnen, eine rote Feder, einen Satz Kauri zum Weissagen, Muscheln für die Göttin Oxum.

Mãe Oya fragt, ob sie mir das alles abkaufen könnte.

\section{Es sei ein Geschenk.}

Das durchbricht die Unpässlichkeit der Greisin und begeistert wie früher wirft sie die Arme hoch und jubelt und sagt, wir sollten pünktlich um eins und weiss gekleidet erscheinen.

Ich habe an alles gedacht, aber eine weisse Hose habe ich vergessen.

Ich frage im Hotel, ob mir der Garçon eine leihen kann, oder eine Pyjamahose.

Nur der Koch besitzt eine weisse Hose. Aber er hat nicht meine Statur.

Dann sind wir mitten drin.

Opfer für Exu im Haus von Exu. Kerzen. Blut. Trommeln. Kräuter.

\section{Seite 115}

Areia aspergida ordenadamente no santuário, as galinhas amarradas às cadeiras e mesas. Os bodes balem.

Mas Mãe Oya está indisposta. Ela tem objeções.

- O sacrifício foi ontem.

- O sacrifício não existe.

- Do sacrifício de hoje à noite vocês não podem participar.

Os dignatários da casa são meus amigos e quando eu digo que nós viemos extraordinariamente durante a noite até aqui, para ver tudo e para fotografar, a comunidade concorda com um aceno de cabeça para convencer a sacerdotisa.

Eu preparei pequenos pacotinhos: nozes-decola africanas, nozes orobó, feijões bedjeregum, uma pena vermelha, um conjunto de cauris para a predição, conchas para a deusa Oxum.

Mãe Oya pergunta se ela poderia comprar tudo isso de mim.

Era um presente.

Isso rompe a indisposição da anciã $e$, entusiasmada como antes, ela joga os braços para cima e exulta e diz que devemos aparecer pontualmente à uma e vestidos de branco.

Eu pensei em tudo, mas de uma calça branca, eu esqueci.

Eu pergunto no hotel se o Garçon pode me emprestar uma, ou uma calça de pijama.

Só o cozinheiro possui uma calça branca. Mas ele não tem a minha estatura.

Então nós estamos no meio de tudo.

Sacrifício para Exú na casa de Exú. Velas. Sangue.Tambores. Ervas.

\section{Página 115}


Die Beteiligten benehmen sich, als handle es sich um etwas ganz Alltägliches.

Brummigkeit und Understatement aller Magier.

Die Novizen entblössen den Oberkörper.

Der erste setzt sich an den langen Opfertisch aus Beton.

Küchenmesser werden auf ihre Schärfe geprüft. Ziegen und Bökke, Hühner, Enten, Angolahühner, Tauben werden herangezerrt.

Der Trommler kommt.

Die Gläubigen sammeln sich. Die Kinder sind ebenso unbewegt wie die Erwachsenen.

Die Greisin nimmt ein Küchenmesser.

Responsorien.

Der Novize schüttelt sich in Trance.

Die Gehilfen ergreifen einen Bock und halten inn dem Opferpriester hin. Der schneidet die Halsschlagader des Tieres auf. Das Blut läuft in ein geheiligtes Gefäss. Der Kopf des Opfers wird langsam abgetrennt. Sie halten den ausblutenden Rumpf über den Kopf des Neophyten. Der schreit auf, als die Tropfen auf seine Haut fallen. Er zittert. Er schluchzt. Er soll an den freiliegenden Halswirbeln des Opfertieres lecken.

Dem Bock werden die Hoden abgeschnitten und die Läufe. Hoden, Läufe, Kopf auf Porzellanteller dekoriert. Der Opferpriester wirft das Aas in einen Winkel.

Ein Huhn wird geköpft und flattert sich zu Ende, eine Ente, ein Angolahuhn, eine Taube.

Blut über Blut.

Man führt den Überronnenen steif und bewusstlos vom Opfertisch weg und legt inn bäuchlings auf eine Strohmatte, unter die man rituelle Kräuter gebreitet hat.
Os participantes se comportam como se se tratassem de algo bem cotidiano.

Rabugice e Understatement de todos os mágicos.

Os noviços desnudam a parte superior do corpo.

O primeiro senta-se à longa mesa de sacrifício de concreto.

Facas de cozinha são testadas quanto ao seu corte. Cabras e bodes, galinhas, patos, galinhas d'angola, pombas são arrastados para lá.

O tocador de tambor chega.

Os fiéis se reunem. As crianças estão igualmente impassíveis como os adultos.

A anciã pega uma faca de cozinha.

Responsórios.

O noviço se sacode no transe.

Os auxiliares agarram um bode e estendem-no para o sacerdote do sacrifício. Ele corta a veia jugular do animal. $O$ sangue corre para um recipiente consagrado. A cabeça da vítima é separada devagar. Eles seguram a carcaça sangrenta sobre a cabeça do neófito. Ele grita quando as gotas caem sobre sua pele. Ele treme. Ele soluça. Ele deve lamber as vértebras cervicais expostas do animal de sacrifício.

Do bode são cortados os testículos e as pernas. Testículos, pernas, cabeça decorados em prato de porcelana. O sacerdote do sacrifício joga a carniça num canto.

Uma galinha é decapitada e bate as asas até o fim, um pato, uma galinha d'angola, uma pomba.

Sangue sobre sangue.

Conduzem o escorrido, rijo e inconsciente, para fora da mesa de sacrifício e deitam-no de barriga para baixo sobre uma esteira de palha, sob a qual se espalharam ervas rituais. 
Es sind die gleichen Kräuter, auf denen er drei Wochen oder drei Monate geschlafen hat.

Die Mönche des Mittelalters benützen das Kraut Vitex agnuscastus als Unterlage, um keusch zu bleiben wie ein Lamm.

Blut und Exkremente ditschen auf dem Boden. Die Beine der Priester sind blutverkrustet.

Sie drücken dem Neophyten Taubenfedern und Federn der Angolahühnern ins Gesicht, auf die Blutspuren.

Der Eingeweihte sieht aus wie ein Gekreuzigter, der sich in einen Vogel verwandelt.

\section{Seite 116}

Ein letztes Mal zu Professora Dona Theresa.

Die kleine Epileptikerin, der Gott Omolu, arbeitet noch immer in der Küche die Einweihungsschulden ab.

- Geht es besser mit deinen Anfällen?

- Viel besser.

- Kannst du jetzt in die Schule gehen wie die anderen?

Das Mädchen antwortet nicht und schrubbt weiter.
São as mesmas ervas sobre as quais ele dormiu três semanas ou três meses.

Os monges da Idade Média usam a erva Vitex agnuscastus como base para permanecerem castos como um cordeiro.

Sangue e excrementos ensopam o chão. As pernas dos sacerdotes estão incrustadas de sangue.

Eles apertam penas de pombos e penas de galinha d'angola no rosto do neófito, nos rastros de sangue.

O iniciado se parece com um crucificado que se transformou em um pássaro.

\section{Página 116}

Uma última vez à Professora DonaTheresa.

A pequena epiléptica, o deus Omulú, trabalha ainda na cozinha para pagar as dívidas da iniciação.

- Está melhor dos seus ataques?

- Muito melhor.

- Você pode agora ir à escola como os outros?

A menina não responde e continua esfregando. 


\section{CAPÍTULO IV - COMENTÁRIOS À TRADUÇÃO DE XANGÔ}

Uma pergunta central nesse capítulo e também para a conclusão da dissertação é a seguinte: em que medida essa estratégia de tradução, cujas diretrizes foram delineadas no capítulo II, contribui para dar a conhecer a obra a leitores brasileiros? O que, na verdade, essa estratégia dá a conhecer para além de um "mero" conteúdo? As anotações de Hubert Fichte são resultado de observações movidas por uma percepção sensível do Outro, do Estranho, dos miseráveis e renegados nessa cultura estrangeira, e ganham corpo no próprio texto. Em seu romance Der Platz der Gehenkten (A praça dos enforcados), de 1985, que constitui o volume VI de seu projeto Geschichte der Empfindlichkeit (História da Sensibilidade), Fichte declara por meio de seu alter ego Jäcki: "Die Djemaa el Fna geht durch mich hindurch" (A Djemaa el Fna passa através de mim), o que significa que o observador/artista não somente relata uma realidade, mas essa realidade objetiva passa por sua sensibilidade e é devolvida em elaboração estética como procedimento criador.

Se buscarmos a origem etimológica da palavra "estética" (do grego aisthetiké = aquele que nota, percebe), pode-se dizer que Fichte, em seu exercício de "observação estética", não percebe somente o positivo, mas sente igualmente o feio, o horrendo, o injusto e o devolve ao leitor, denunciando o quadro de forma crítica. Minha intenção ao traduzir, portanto, é a de aproximar o leitor o quanto possível desse processo sensível e fazer com que o texto não seja visto de forma distanciada e indiferente, mas que desperte no leitor, por meio de um estranhamento, de um desconforto, uma atitude de sensibilização crítica.

Os comentários contemplaram a estratégia de tradução, seguindo as orientações dos teóricos de tradução sobre os quais discorremos no capítulo II desta dissertação. Desse modo, procuramos construir no idioma de chegada as estruturas sintáticas (ordem dos elementos na frase e posição de atributos) e algumas questões lexicais com o maior grau de literalidade possível para produzir um efeito estrangeirizante e mais próximo do idioma de partida, conservando certas expressões idiomáticas sem transpô-las de acordo com o correspondente em português 
(SCHLEIERMACHER, 2010 [1813]; VENUTI, 1995; e BERMAN, 2007), no entanto, cuidando para manter a inteligibilidade do texto (NORD, 1989).

As referências teuto-europeias mereceram atenção em virtude de sua ancoragem na cultura de origem e nas vivências do autor, utilizada por ele para interpretar as novas experiências e, em alguns casos, pela sua imbricação com dados biográficos de Hubert Fichte, fator que nos auxilia na interpretação da obra e, por conseguinte, nas escolhas tradutórias.

As frases da ditatura foram eleitas para o rol dos comentários por terem sido traduzidas a partir de uma ancoragem da tradutora em sua vivência desse período histórico no Brasil, e por revelarem o envolvimento do autor com os fatos políticos, além dos sociais e culturais, no relato crítico das suas experiências em sua estada no Brasil.

Destacaram-se também as questões relacionadas ao universo da religião, item no qual optei pela estratégia de acomodação ao modo de escrita de objetos, divindades e fenômenos, para preservar a identidade cultural do grupo religioso.

A relevância dos comentários sobre os títulos de jornais e revistas consiste no papel que desempenham na técnica de colagem utilizada por Hubert Fichte na obra. Há também o fato de que a maioria é representante de uma ideologia conservadora e colaborava com o regime político repressor da época, o que dá oportunidade ao autor de desenvolver sua crítica, partindo do material veiculado por essa imprensa.

Não são de somenos importância as pausas que separam por assunto os quadros retratados, narrados e comentados por Fichte, que receberam três asteriscos como símbolo: ***. Além de sinalizarem uma mudança de cenário, representam um intervalo para reflexão sobre o conteúdo, denso, irônico e crítico da obra.

Por fim, gostaria de fazer referência a uma categoria de palavras e expressões que foram registradas por Hubert Fichte em português no texto original. Elas aparecem no texto de chegada com um asterisco, como recurso para indicar que não se trata de tradução.

Os comentários à tradução foram, portanto, subdivididos nas categorias listadas abaixo: 
1. Questões de sintaxe

2. Referências teuto-europeias

3. Questões lexicais

4. Frases da ditadura

5. Questões relacionadas ao universo da religião

6. Títulos de jornais e revistas

As categorias acima foram organizadas em tabelas bicolunadas, nas quais 0 exemplo em alemão encontra-se do lado esquerdo, seguido do número da página original do livro de onde foram retirados, do lado direito está a tradução para o português. Abaixo da tabela estão os comentários correspondentes a cada exemplo.

\section{COMENTÁRIOS}

\section{Questões de sintaxe}

Os comentários referentes a essa categoria caracterizam-se pela literalidade na sintaxe, ou seja, pela conservação da ordem das palavras como no texto de partida, sempre que possível, e na colocação dos atributos antes dos substantivos.

Para melhor compreender essa atitude tradutória, retomamos algumas noções básicas da distribuição dos elementos constituintes da oração principal (Satzglieder), que possuem em cada idioma uma determinada sequência e não permitem combinações aleatórias ${ }^{31}$. No português, a ordem fixou-se entre dois polos: o gramatical e o estilístico, de acordo com CÂMARA JUNIOR (1976) ${ }^{32}$, o que confere certa maleabilidade na ordenação dos elementos. No entanto, a colocação do nível

\footnotetext{
${ }^{31}$ WELKER, Herbert Andreas. Gramática alemã. Brasília: Editora Universidade de Brasília, 2004.

${ }^{32}$ CAMARA JR. J. História da Língua Portuguesa. Rio de Janeiro: Padrão, 1976.
} 
estilístico estaria, segundo esse autor, submetida às regras gramaticais. No idioma alemão, essa organização assume caráter mais rígido. Por exemplo, o verbo conjugado, considerado como o núcleo da oração, assume posições definidas, tanto na oração principal, quanto na subordinada.

Levando-se em conta que os textos de Hubert Fichte possuem como forte característica a ocorrência de períodos curtos, nosso interesse se concentrou, portanto, nas orações principais. Nessas orações independentes e completas, o verbo ocupa a posição II, sendo que o sujeito pode mudar da posição I à III ou IV, movimentando-se sempre em torno de seu verbo conjugado. Já na sintaxe do português, a ordem em que as unidades linguísticas aparecem na oração pode assumir outros padrões além da construção direta de sujeito + verbo + objeto, possibilitando mais mobilidade dos elementos. Isso nos facilitou uma disposição mais literal dos termos na oração, respeitando sempre que possível a ordem sintática do idioma de partida.

A mesma atenção foi dedicada aos adjetivos atributivos, que no alemão aparecem antepostos ao substantivo que descrevem. Como no português essa colocação do adjetivo pode acarretar uma mudança de sentido, tivemos cuidado com essa restrição, optando, no entanto, pela anteposição, quando essa não causava uma alteração semântica.

Nos exemplos a seguir, podem-se observar os procedimentos descritos acima.

\begin{tabular}{|l|l|}
\hline ALEMÃO & PORTUGUÊS \\
\hline $\begin{array}{l}\text { Die Justiz ist teilweise noch intakt. (p. } \\
\text { 8) }\end{array}$ & A justiça está, em parte, ainda intacta. \\
\hline $\begin{array}{l}\text { In den besseren Vierteln der Stadt } \\
\text { wird gebaut. Viel. Hochhäuser à la } \\
\text { Mies van der Rohe. (p. 8) }\end{array}$ & $\begin{array}{l}\text { Nos melhores bairros da cidade se } \\
\text { constrói. Muito. Prédios altos à la Mies } \\
\text { van der Rohe. }\end{array}$ \\
\hline $\begin{array}{l}\text { Ein zitternder Angestellter mag mir } \\
\text { die Adresse nicht nennen und er mag } \\
\text { sie mir nicht nicht nennen. (p. 8) }\end{array}$ & $\begin{array}{l}\text { Um trêmulo empregado não quer me } \\
\text { dar o endereço e ele não quer não me } \\
\text { dar o endereço. }\end{array}$ \\
\hline
\end{tabular}




\begin{tabular}{|l|l|}
\hline $\begin{array}{l}\text { Im Novo Engenho Velho flieht ein } \\
\text { Mädchen vor uns. Eine Alte sagt uns, } \\
\text { im Februar wird es ein Fest geben. } \\
\text { (p.13) }\end{array}$ & $\begin{array}{l}\text { Em Novo Engenho Velho foge uma } \\
\text { menina de nós. Uma velha nos diz, em } \\
\text { fevereiro haverá uma festa. }\end{array}$ \\
\hline $\begin{array}{l}\text { Sie ist im achten Monat schwanger. } \\
\text { (p. 24) }\end{array}$ & Ela está grávida no oitavo mês. \\
\hline $\begin{array}{l}\text { Ein Geistlicher mit einer } \\
\text { disproportionierten weissen } \\
\text { Sportmütze kommt. (p. 26) }\end{array}$ & $\begin{array}{l}\text { Um sacerdote com um desproporcional } \\
\text { boné esportivo chega. }\end{array}$ \\
\hline $\begin{array}{l}\text { Aber afrikanisches Indigo ist in Bahia } \\
\text { selten geworden. (p. 31) }\end{array}$ & $\begin{array}{l}\text { Mas índigo africano tornou-se na Bahia } \\
\text { raro. }\end{array}$ \\
\hline $\begin{array}{l}\text { Der Altar ist mit kleinen, bunten, } \\
\text { elektrischen Birnen geschmückt. }\end{array}$ & $\begin{array}{l}\text { O altar é decorado com pequenas, } \\
\text { coloridas, lâmpadas elétricas. }\end{array}$ \\
\hline $\begin{array}{l}\text { Betreten dürfen wir keines. (p. 35) } \\
\text { Entrar não podemos em nenhuma. }\end{array}$ \\
\hline $\begin{array}{l}\text { Offen Schlechtes über den Toten zu } \\
\text { sagen, verbietet der Takt des } \\
\text { Afrikaners und die Furcht vor der } \\
\text { marodierenden Seele des Toten. (p. } \\
\text { 70) }\end{array}$ & $\begin{array}{l}\text { Falar mal abertamente do morto, a } \\
\text { prudência do africano proíbe, assim } \\
\text { como o temor da devastadora alma do } \\
\text { morto. }\end{array}$ \\
\hline $\begin{array}{l}\text { Göttergesänge, zwei Reihen von } \\
\text { singenden, tanzenden Töchtern des } \\
\text { Toten bilden sich. (p. 74) }\end{array}$ & $\begin{array}{l}\text { Cantos dos deuses, duas fileiras de } \\
\text { cantantes e dançantes filhas do morto } \\
\text { se formam. }\end{array}$ \\
\hline $\begin{array}{l}\text { Dieser Zustand dauert bereits 400 } \\
\text { Jahre. (p. 80) }\end{array}$ & Esse estado dura já 400 anos. \\
\hline
\end{tabular}

Die Justiz ist teilweise noch intakt. (A justiça está parcialmente ainda intacta.) A oração seguiu a ordem direta dos elementos, com destaque para a colocação do "ainda", cuja posição mais natural no português seria antes do verbo de ligação.

In den besseren Viertel der Stadt wird gebaut. (Nos melhores bairros da cidade se constrói.) Seguimos a ordem sintática do idioma de partida, mantendo o objeto indireto na posição I. Utilizamos no lugar da voz passiva de ação (Vorgangspassiv) a voz passiva sintética no português, que não existe em alemão e corresponde nesse idioma à voz ativa com o pronome indefinido man. Mesmo assim, não nos pareceu adequada a mudança da voz verbal, portanto conservamos a voz passiva no idioma de chegada, como solução mais natural. 


\section{Ein zitternder Angestellter mag mir die Adresse nicht nennen und er mag sie mir} nicht nicht nennen. (Um trêmulo empregado não quer me dar o endereço e ele não quer não me dar o endereço.) Conservamos o adjetivo atributivo antes de seu substantivo, "empregado". Gostaríamos de chamar a atenção para a dupla negação em "er mag sie mir nicht nicht nennen", pois foi a intenção do autor transmitir o conflito do trêmulo empregado entre sua vontade e as regras que deveria seguir.

Im Novo Engenho Velho flieht ein Mädchen vor uns. Eine Alte sagt uns, im Februar wird es ein Fest geben. (Em Novo Engenho Velho foge uma menina de nós. Uma velha nos diz, em fevereiro haverá uma festa.) Na primeira oração do período, merece destaque a colocação do verbo na posição II, mantendo a literalidade sintática. No segundo período, o foco da estratégia se encontra na oração subordinada, na qual omitimos a conjunção "que" do discurso indireto, o qual segue o verbo de elocução que separa a fala do emissor da fala do receptor. Esse recurso, em geral obrigatório no português para manter a inteligibilidade da mensagem, não sofreu perdas no período em questão, embora cause um certo estranhamento, o que faz parte da nossa proposta de tradução.

Sie ist im achten Monat schwanger. (Ela está grávida no oitavo mês.) A primeira tradução nossa foi "Ela está grávida de oito meses". Teria sido uma estratégia de adaptação, e optamos novamente pelo estranhamento ${ }^{33} \mathrm{com}$ o uso da contração da preposição "em + artigo masculino "o" ("no").

\section{Ein Geistlicher mit einer disproportionierten weissen Sportmütze kommt.} (Um sacerdote com um desproporcional boné esportivo chega.) A conservação do verbo no final da oração foi possível devido ao caráter de verbo intransitivo de "chegar" nesse contexto, significando "atingir o lugar de destino", não necessitando de um complemento.

\footnotetext{
${ }^{33} \mathrm{Em}$ sua obra $A$ arte como procedimento, o formalista russo Viktor Chklóvski afirma sobre o estranhamento (Ostranenie, em russo) na linguagem literária que: (...) tanto nas suas constituintes fonéticas e lexicais como na disposição das palavras e nas construções semânticas constituídas por estas palavras, percebemos que o caráter estético se revela sempre pelos mesmos sinais: é criado conscientemente para libertar a percepção do automatismo. In: TOLEDO, Dionísio de Oliveira (org.). Teoria da literatura: formalistas russos. Porto Alegre: Globo, 1978: 5.
} 
Aber afrikanisches Indigo ist in Bahia selten geworden. (Mas índigo africano tornou-se na Bahia raro.) O predicativo do sujeito não foi diretamente posposto ao seu verbo de ligação, mas ao objeto indireto da oração. Embora essa não seja a sua posição usual, não houve interferência na compreensão da oração, tratando-se, portanto, de um desvio admissível.

Der Altar ist mit kleinen, bunten, elektrischen Birnen geschmückt. ( $O$ altar é decorado com pequenas, coloridas, lâmpadas elétricas.) A enumeração dos adjetivos denotativos (pequenas, coloridas) referentes a lâmpada, que servem para destacar e avaliar as propriedades do objeto, pode ser mantida, ao passo que em "lâmpadas elétricas", o adjetivo tem propriedade restritiva, de identificação do substantivo que acompanha, não se admitindo, nesse caso, a anteposição no português.

Betreten dürfen wir keines. (Entrar, não podemos em nenhuma.) Nesse caso houve um desvio do padrão sintático direto na organização dos elementos na oração. Conservamos a ordem inversa, com o verbo infinitivo iniciando a oração, para preservar a ênfase na ação do verbo.

Offen Schlechtes über den Toten zu sagen, verbietet der Takt des Afrikaners und die Furcht vor der marodierenden Seele des Toten. (Falar mal abertamente do morto, a prudência do africano proíbe, assim como o temor da devastadora alma do morto.) Aqui se respeitou a inversão da ordem de colocação das orações, iniciandose com a oração subordinada infinitiva. Entretanto não foi possível manter o verbo no início da oração principal, como dita a regra de inversão no idioma alemão. Tal procedimento se coaduna com a nossa proposta de tradução, de se encontrar o meio do caminho nas soluções, para manter a inteligibilidade.

Göttergesänge, zwei Reihen von singenden, tanzenden Töchtern des Toten bilden sich. (Cantos dos deuses, duas fileiras de cantantes e dançantes filhas do morto se formam.) Nossa primeira tendência foi traduzir os adjuntos adnominais no particípio I em alemão por uma oração subordinada, introduzida pela conjunção "que" (filhas que cantam e dançam). Numa segunda leitura, decidimo-nos pelos adjetivos "cantantes e dançantes" antepostos ao substantivo, como no texto de origem. 
Dieser Zustand dauert bereits 400 Jahre. (Esse estado dura já 400 anos.) A flexibilidade da posição do advérbio de tempo em português, que pode ser colocado antes ou depois do verbo que modifica, favoreceu-nos na conservação do padrão sintático do alemão.

\section{Referências teuto-europeias}

As referências teuto-europeias se ancoram na bagagem cultural e nas memórias das vivências do autor, que o auxiliam a interpretar a nova realidade. Segundo o conceito de representação social de Moscovicl (1978: 35), as representações sociais, em especial a ancoragem, tornam familiar algo até então desconhecido, classificam e dão nome a novos acontecimentos e ideias, interpretando esses fenômenos a partir de conhecimentos e valores pré-existentes e consolidados no meio social do indivíduo. Como afirma o teórico romeno:

\footnotetext{
Nenhuma mente está livre dos efeitos de condicionamentos anteriores que Ihe são impostos por suas representações, linguagem ou cultura. Nós pensamos através de uma linguagem, nós organizamos nossos pensamentos de acordo com um sistema que está condicionado, tanto por nossas representações, como por nossa cultura. ${ }^{34}$
}

Assim, Hubert Fichte, como sujeito cognoscente, utiliza muitas dessas referências para criar associações que o auxiliem nesse processo de ressignificação desse novo sistema social e cultural.

Segue abaixo uma listagem das principais referências, segundo nosso entendimento.

${ }^{34} \mathrm{MOSCOVICl}$, Serge. A representação social da psicanálise. Rio de Janeiro: Zahar, 1978. 


\begin{tabular}{|c|c|}
\hline EM ALEMÃO & TRADUÇÃOO \\
\hline $\begin{array}{l}\text { Gibt es nicht bei Goethe eine } \\
\text { Bemerkung über das Glänzen der Haut } \\
\text { im Kerzenlicht? (p. } 7)\end{array}$ & $\begin{array}{l}\text { Não há em Goethe uma } \\
\text { observação sobre o brilho da pele } \\
\text { à luz da vela? }\end{array}$ \\
\hline $\begin{array}{l}\text { Hier war Goethe nicht. Doch wo Goethe } \\
\text { nicht hinkam, war Italiaander. } \\
\text { (p. 7) }\end{array}$ & $\begin{array}{l}\text { Aqui Goethe não esteve. Mas } \\
\text { aonde Goethe não foi, lá esteve } \\
\text { Italiaander. }\end{array}$ \\
\hline Freie und Hansestadt Hamburg (p. 7) & $\begin{array}{l}\text { Cidade Livre e Hanseática de } \\
\text { Hamburgo }\end{array}$ \\
\hline à la Mies van der Rohe (p. 8) & à la Mies van der Rohe \\
\hline Chansonsänger (p. 8) & Cantores de chanson \\
\hline Pop Art (p.8) & Pop Art \\
\hline Ich habe das E.E. 1. (p. 10) & $\begin{array}{l}\text { Eu tenho a Cruz de Ferro de } 1^{\circ} \\
\text { classe. }\end{array}$ \\
\hline Ich bin rosa. (p. 10) & Eu sou rosa. \\
\hline $\begin{array}{l}\text { Meine Frau bekommt hier sogar Maggi } \\
\text { Streuwürze. (p. 11) }\end{array}$ & $\begin{array}{l}\text { Minha mulher recebe aqui até o } \\
\text { tempero granulado Maggi. }\end{array}$ \\
\hline Subproletariat (p. 14) & Subproletariado \\
\hline Hitler, so! (p. 14) & Ah, Hitler! \\
\hline B.B. (p. 17) & B.B. \\
\hline Leonore Mau $\quad$ (p. 10) & Leonore Mau \\
\hline Jean Paul Sartre (p. 25) & Jean Paul Sartre \\
\hline Simone de Beauvoir (p. 25) & Simone de Beauvoir \\
\hline François Duvalier (p. 16) & François Duvalier \\
\hline Hasselblad (p. 28) & Câmera fotográfica Hasselblad \\
\hline Mühl (p. 31) & Mühl \\
\hline Nitsch (p. 31) & Nitsch \\
\hline Lil Picard (p. 31) & Lil Picard \\
\hline Schwarzsauer (p. 38) & Sopa preta alemã Schwarzsauer \\
\hline $\begin{array}{l}\text { Lampião - Lampion - küsste keine } \\
\text { Birken. (p. 51) }\end{array}$ & $\begin{array}{l}\text { Lampião - Lampioon - não beijava } \\
\text { bétulas. }\end{array}$ \\
\hline Herman Miller Collection (p. 52) & Coleção Herman Miller \\
\hline Gastarbeiter (p. 55) & Trabalhadores convidados \\
\hline $\begin{array}{l}\text { Die Legende von Franz von Assisi ( } p . \\
65 \text { ) }\end{array}$ & A lenda de Franz von Assisi \\
\hline $\begin{array}{l}\text { Im deutschen Märchen spielt der Junge } \\
\text { auf den Knöchelchen seines Bruders. } \\
\text { (p. 73) }\end{array}$ & $\begin{array}{l}\text { No conto de fadas alemão, o } \\
\text { menino tocava nos ossinhos de } \\
\text { seu irmão. }\end{array}$ \\
\hline Charons Pfennige (p. 79) & Pfennigs de Caronte \\
\hline Nixe (p. 79) & Nixie \\
\hline Testaniére (p. 79) & Testanière \\
\hline Cartacalo/la (p. 79) & Cartacalo/la \\
\hline Schrebergartenkolonie (p. 79) & Colônia de jardins de Schreber \\
\hline Quirinus Kuhlmann (p. 79) & Quirinus Kuhlmann \\
\hline Menjoubart (p. 79) & Barba Menjou \\
\hline
\end{tabular}


Goethe: brilho da pele à luz da vela. (Não há em Goethe uma observação sobre o brilho da pele à luz da vela?) Há uma discussão sobre o assunto na obra „ICh bin nicht der erste Fremde hier.". Zur deutschsprachigen Reiseliteratur nach 1945 ("Eu não sou o único estrangeiro aqui.". Sobre a literatura de viagem em língua alemã após 1945) de Ulla Biernat ${ }^{35}$, com referência à "Italienische Reise” de Goethe, modelo de literatura de viagem, formador desse estilo, que exerceu influência no séc. XX. Isso aponta um indício de que Fichte escreve um relato de viagem. A autora cita a obra de Herbert Uerling, „Poetiken der Interkulturalität” (Poéticas da interculturalidade) ${ }^{36}$, na qual o Uerling discorre sobre a ligação entre a interculturalidade e a intertextualidade nos relatos de viagem de Fichte. Nesse contexto, Uerling define três tipos de intertextualidade: 1) Reação a um discurso existente, o da etnologia, 2) Intertextualidade como diversidade de forma, 3) Intertextualidade como diversidade de discurso cultural. Entre esses polos movimenta-se a etnopoesia de Hubert Fichte, e se esforça para esclarecer o que se pode entender, deixar quieto o insolúvel e deixar claro o processo de experiência e aquisição de conhecimento.

Italiaander - Rolf Italiaander (1913 - 1991), escritor, tradutor e etnólogo alemão de Hamburgo, africanista, realizou diversas viagens e expedições de pesquisa à África. Reivindicou os direitos dos homossexuais ${ }^{37}$. Há uma identificação de Fichte com Italiaander, pesquisador e estudioso da cultura africana. Em seus relatos de viagem, Italiaander atualiza o significado do legado deixado por Goethe aos viajantes que escrevem suas impressões de observação cultural e confronto em seus relatos.

Cidade Livre e Hanseática de Hamburgo - nome oficial da cidade de Hamburgo, remete à sua história como membro da Liga Hanseática medieval, quando era uma Cidade Imperial Livre do Sacro Império Romano, equivalente a uma cidade-estado. Trata-se de uma referência à cidade natal de Hubert Fichte. Ao utilizar o nome oficial, o autor imprime um tom de ironia e crítica.

\footnotetext{
${ }^{35}$ BIERNAT. Ulla. Ich bin nicht der erste Fremde hier. Zur deutschsprachigen Reiseliteratur nach 1945. Würzburg: Königshausen \& Neumann, 2004: 28.

${ }^{36}$ UERLING, Herber. Poetiken der Interkulturalität: Haiti bei Kleist, Seghers, Müller, Buch und Fichte. Tübingen: Niemeyer, 1997.

${ }^{37}$ KILLY LITERATURLEXIKON. Autoren und Werke des deutschsprachigen Kulturraums (2009: 62-63).
} 
Ludwig Mies van der Rohe (1886 - 1969) - Arquiteto alemão naturalizado americano, considerado um dos principais nomes da arquitetura do século XX. Foi professor da Bauhaus e um dos criadores do International style, arquitetura caracterizada pelo racionalismo, pela utilização de uma geometria clara e pela sofisticação ${ }^{38}$.

Chansonsänger (cantores de chanson / Chanson - Segundo Michèle Aquien, em seu "Dictionnaire de Poétique", a palavra chanson (do latim arcaico e pós-clássico cantio, para o clássico cantus = canto) é muito antiga e significa uma peça de versos simples, destinada ao canto com acompanhamento instrumental. $O$ fator comum que remete a toda e qualquer chanson é o texto escrito na língua francesa, estruturado sobre alguma forma poética (ainda que essa possa ser livre) e que versa sobre um tema específico ${ }^{39}$. A escolha dessa denominação revela uma aproximação cultural a partir de um termo conhecido, como a chanson. No Romantismo, a chanson aparece nas obras de Debussy, Fauré e Ravel em contraposição ao Lied alemão ${ }^{40}$. Hubert Fichte provavelmente se refere aos cantores de Música Popular Brasileira (MPB), que confrontaram o regime ditatorial militar de forma direta ou através de metáforas nas letras de suas canções.

Pop Art - Na década de 1960, os artistas defendem uma arte popular (pop) que se comunique diretamente com o público por meio de signos e símbolos retirados do imaginário que cerca a cultura de massa e a vida cotidiana. A defesa do popular traduz uma atitude artística contrária ao hermetismo da arte moderna. Nesse sentido, a arte pop se coloca na cena artística que tem lugar em fins da década de 1950 como um dos movimentos que recusam a separação arte/vida. Um de seus traços característicos é a incorporação das histórias em quadrinhos, da publicidade, das imagens televisivas e do cinema ${ }^{41}$.

Percebemos aqui uma associação com a arte degenerada (entartete Kunst), designação que compreendia movimentos artísticos modernos como o Bauhaus, o

\footnotetext{
${ }^{38}$ BLASER, Werner. Mies Van Der Rohe. São Paulo: Martins Fontes, 2001.

${ }^{39}$ AQUIEN, M.; MOLINIÉ, G. Dictionnaire de rhétorique et de poétique. Paris: Libr. générale française, 1999.

${ }^{40}$ AUTRAN DOURADO, Henrique. Dicionário de termos e expressão da música. São Paulo: Editora 34, 2004.

${ }^{41}$ ARTE Pop. In: ENCICLOPÉDIA Itaú Cultural de Arte e Cultura Brasileiras. São Paulo: Itaú Cultural, 2017. Disponível em <http: encyclopedia. Itaucultural. org.br/termo 367/arte-pop>. Acesso em 5. maio 2017.
} 
Dadaísmo, o Cubismo, o Expressionismo e o Surrealismo, e que foi proibida no regime nazista de Hitler, por ser não germânica ou de natureza judaico-bolchevique.

No Brasil, os artistas adaptaram a pop art norte-americana para criticar o imperialismo, a cultura de massa e o autoritarismo do regime militar. Opuseram resistência nas grandes exposições de arte, como na pré-Bienal de Paris, realizada no Museu de Arte Moderna do Rio de Janeiro em 1969, que foi encerrada por ordem dos militares ${ }^{42}$.

E. K. 1. - Eisernes Kreuz 1._= Cruz de Ferro de primeira classe. A Cruz de Ferro foi uma condecoração militar do Reino da Prússia, concedida mais tarde pelo Império Alemão e pelo Terceiro Reich. Trata-se de uma medalha concedida por bravura na guerra. Em 1939, Hitler reinstituiu por decreto a Ordem da Cruz de Ferro, que passou a emitir a medalha em dois graus: a Cruz de Ferro de $2^{a}$ classe e a Cruz de Ferro de $1^{\text {a }}$ classe. Na fala transcrita por Fichte nessa passagem do livro, nota-se o orgulho do emissor ao declarar que foi condecorado com a Cruz de Ferro de $1^{\text {a }}$ classe e simultaneamente uma crítica com laivos irônicos do autor quanto a esse posicionamento ${ }^{43}$.

A cor rosa foi usada na perseguição do nacional-socialismo aos homossexuais que eram presos pelo regime e marcados com um triângulo rosa. Mais tarde ela foi retomada como símbolo desse grupo no movimento dos homossexuais na década de $1970^{44}$. Essa referência remete-nos, provavelmente, a esse significado simbólico.

Tempero granulado Maggi: criado em 1956, esta é uma marca do fabricante suíço Nestlé. No Brasil, a Maggi está presente desde 196145. Receber o tempero Maggi revela uma atitude etnocêntrica dos conterrâneos de Fichte. Significa poder

\footnotetext{
42 10a BIENAL DE SÃO PAULO. In: ENCICLOPÉDIA Itaú Cultural de Arte e Cultura Brasileiras. São Paulo: Itaú Cultural, 2017. Disponível em <http: encyclopedia.itaucultural. org.br/termo 335/bienal-internacional-de-sãopaulo>. Acesso em 5. maio 2017.

${ }^{43}$ MIRANDA, Francisco. Medalhas \& Condecorações: A Cruz de Ferro. Disponível em:

chicomiranda.wordpress.com/2011/06/17/medalhas-condecoracoes-a-cruz-de-ferro. Acesso em 15 abr. 2017.

${ }^{44}$ SCHWARTZ, Michael. Homossexuelle im Nationalsozialismus. München: De Gruyter, 2014: 21.

${ }^{45}$ MUNDO DAS MARCAS. Maggi: Muito mais que um caldo nobre.

Disponível em: http://mundodasmarcas.blogspot.com.br/2006/05/maggi-muito-mais-que-um-caldonobre.html. Acessos em 15. Apr 2016.
} 
usufruir da qualidade dos produtos do primeiro mundo e não precisar sentir muita falta de sua cultura europeia de origem.

Subproletariat (subproletariado) - O termo subproletariado, com seus sinônimos lumpenproletariado (do composto alemão Lumpen - trapo ou farrapo - + Proletariat proletariado) ou lumpesinato é um termo criado por Karl Marx e Friedrich Engels para designar um grupo do proletariado formado por trabalhadores em extrema situação de miséria, ou pelos indivíduos que exercem atividades marginais, como ladrões e prostitutas. Sua característica principal seria a falta de consciência política e de classe $^{46}$. Em Xangô (19761:14), Hubert Fichte menciona os trabalhadores, os casais e o subproletariado da Bahia de Todos os Santos, que veem no cinema cenas da Europa, como violinos da Floresta Negra e a moda masculina em Berlim, talvez representando uma fuga de sua própria realidade. Ao invés de assumir uma posição e desenvolver uma consciência, aceitam as influências desse neocolonialismo cultural.

Hitler, so! (Ah, Hitler!) - A exclamação é definida por Fichte como uma reação benevolente da população brasileira quando o viajante declara que vem da República Federal da Alemanha. Esse comportamento se deriva do estereótipo que se disseminou no Brasil quanto à imagem de Hitler, principalmente junto a uma camada menos esclarecida da população. É muito comum encontrar cidadãos alemães sendo cumprimentados pela saudação nazista "Heil Hitler", com a intenção de demonstrar simpatia.

B.B. = Brigitte Bardot_(1934 -) atriz francesa, foi símbolo sexual nas décadas de 1960 e 1970 77 . Fichte refere-se ao encontro de Brigitte e Pelé em 1971, na França, ocasião em que o jogador participou de um jogo beneficente em Paris. Notícia divulgada pelo jornal "A Tarde"48.

\footnotetext{
${ }^{46}$ MARX, Karl; ENGELS, Friedrich. Manifest der Kommunistischen Partei. Ditzingen: Reclam, 1986.

47 LELIÈVRE, Marie-Dominique. Brigitte Bardot. Rio de Janeiro: Record, 2014.

${ }^{48}$ SANTORI, Jorge. Brigitte Bardot e Pelé, 1971.

Disponível em: http://antiguinho.blogspot.com.br/2014/06/brigitte-bardot-e-pele-1971.html. Acesso em 16 abr. 2016.
} 
Leonore Mau (1916 - 2013) - fotógrafa profissional e companheira de Fichte, autora das fotos do livro fotográfico com o mesmo título da obra que elegemos para estudar no presente trabalho de dissertação: Xango. Die afroamerikanischen Religionen. Bahia, Haiti, Trinidad. Texte Hubert Fichte (Xango. As religiões afroamericanas. Bahia, Haiti, Trindade, 1976). Sobre o relacionamento e a parceria entre Leonore Mau e Hubert Fichte encontram-se mais detalhes no capítulo 1.4.

Jean Paul Sartre e Simone de Beauvoir ${ }^{49}$ - Sartre e de Simone de Beauvoir visitaram o Brasil em 1960 e permaneceram no país durante quase três meses (de meados de agosto a início de novembro). Sua motivação esteve ligada, essencialmente, às questões filosóficas e político-sociais internacionais e brasileiras do momento. O casal viajou pelo Brasil sempre em companhia de Jorge Amado e não veio na condição de turista. Tinha objetivos filosóficos e políticos, como divulgar as atrocidades cometidas pela França na Guerra da Argélia e difundir a Revolução Cubana entre o público brasileiro. Além disso, Sartre revia o marxismo à luz do existencialismo e, em 1960, acabara de publicar a sua Crítica da razão dialética, livro que teve grande impacto entre muitos intelectuais brasileiros de esquerda. Em Salvador, Sartre e Simone participariam de rituais de Candomblé.

François Duvalier_- médico, etnólogo e ditador haitiano (1957-1971) nascido em Port-au-Prince, cujo governo notabilizou-se pela violência e pelo terror, e que levou o Haiti a uma grave deterioração econômica e social, em consequência do isolamento diplomático quase total da sua nação ${ }^{50}$. Hubert Fichte critica nas entrelinhas o fato de Pelé ter entregue ao ditador François Duvalier uma ordem honorífica brasileira.

Hasselblad: uma empresa sueca, fabricante de câmaras e material fotográfico, fundada por Victor Hasselblad em 1941. Durante o Projeto Apollo, modelos modificados de câmaras Hasselblad foram utilizados pelos astronautas para fotografar

\footnotetext{
${ }^{49}$ ALMEIDA, Rodrigo Davi. A visita de Sartre e Beauvoir ao Brasil.

${ }^{50}$ CABRAL, Danilo Cezar. Papa Doc, o ditador que tocou terror no Haiti. In: Mundo Estranho, 2016. Disponível em: mundoestranho.abril.com.br. Acesso em 17 abr. 2016.
} 
a lua e outros corpos celestes ${ }^{51}$. Essa câmera fotográfica tinha um formato compacto que cabia bem na mão e um peso certo que não cansava o fotógrafo, ideal, portanto, para se realizar fotorreportagens e levar em viagens. A câmera fotográfica Hasselblad simboliza a fotógrafa Leonore Mau e faz referência à sua participação no projeto de pesquisa e documentação em que estão empenhados. Em outra passagem de Xangô (1976:128), Fichte se refere novamente à Hasselblad, ao descrever uma procissão em homenagem à Virgem Maria no Haiti: "Acima do cardeal, o olho do ciclope de uma Hasselblad"52. A imagem da figura mitológica do ciclope, um gigante que vê com apenas um olho, porém tem visão de longo alcance, sugere um empoderamento da figura e do papel da fotógrafa.

Otto Mühl_(1925 - 2013) - artista austríaco, representante dos Acionistas Vienenses - grupo formado por ele, Rudolph Swarzkogler, Gunter Brus e Hermann Nitsch. Eles procuraram transgredir todos os tabus, realizando vídeos, pinturas e performances escatológicas e obscenas. Aparentemente inaceitáveis tanto do ponto de vista moral quanto artístico, tais propostas foram, surpreendentemente, ganhando importância de movimento de vanguarda e conquistando o cânone da História da Arte: como por exemplo, a participação de Otto Mühl em duas exposições no Museu do Louvre (Posséder et Détruire, 2000 e La Peinture comme Crime, 2002). Mühl, após fundar e chefiar por duas décadas uma comuna hippie, passa 6 anos na prisão acusado de pedofilia ${ }^{53}$.

Hermann Nitsch (1938 - ) - pintor e artista acionista austríaco, importante representante do Acionismo Vienense ${ }^{54}$.

Lil Picard_(1899 - 1994) - nascida na Alemanha, emigrou para os Estados Unidos da América durante a perseguição do nacional-socialismo aos judeus. Obteve sucesso como atriz, jornalista, escultora, crítica literária, fotógrafa, entre outros talentos. Participou do movimento avanguardista antiarte, No!Art, cuja proposta era

\footnotetext{
${ }^{51}$ SÖREN, Gunnarsson. Victor Hasselblad 1906 - 2006. A short biography. Göteborg: Victor Hasselblad AB, 2006.

52 “Über dem Kardinal das Zyklopenauge einer Hasselblad"

${ }^{53}$ SILVA, Priscilla Ramos da. Os Acionistas Vienenses: revolucionários ou perversos? VI Encontro de História da Arte. IFCH/UNICAMP. Campinas, 2008: 240.

${ }^{54}$ ACKERMANN, Marion. Drei: Das Triptychon in der Moderne. Berlim: Hatje Cantz Verlag, 2009.
} 
chocar a sociedade vanguardista, o fascismo, o racismo e o imperialismo na política da época em que viviam ${ }^{55}$. Nos anos de 1970, Hubert Fichte realizou duas entrevistas com Lil Picard em Nova lorque. O registro dessas duas entrevistas encontra-se em duas obras de Fichte que pertencem ao seu romance fleuve da "Geschichte der Empfindlichkeit" ("História da Sensibilidade"). A primeira, "Paraleipomena - Lil's Book. Das Leben der Künstlerin Lil Picard erzählt im Gespräch mit Hubert Fichte" ("Paraleipomena - Lil's Book. A vida da artista Lil Picard contada em conversa com Hubert Fichte" - 1991) contém entrevistas realizadas entre novembro de 1975 e fevereiro de 1976, e em outubro de 1979 com Lil Picard. Para Fichte, essas entrevistas fizeram parte de um projeto de pesquisa etnológico sobre os ritos e rituais da cena pop-art de Nova lorque, observando e acompanhando a carreira de Andy Warhol, Jackson Pollock, entre outros artistas representantes dessa manifestação artística. Ademais, traça um perfil da artista judia Lil Picard, expulsa da Alemanha pelo regime nacional-socialista ${ }^{56}$. A segunda obra, Die Schwarze Stadt (A cidade preta - 1990), é um livro de ensaios e registros de entrevistas do período entre 1978 e 1980, também em Nova lorque. A intenção de abordagem é etnográfica, como na obra citada anteriormente, porém se concentra na cidade norte-americana, que ele chama de "Roma do nosso século", tanto pela sua mistura de povos, quanto pela miséria e riqueza. Entrevistas, como por exemplo, o fotógrafo Richard Avedon, a artista Lil Picard e um japonês iniciado em vudu, compões esse estudo. RIEGER (2009) ${ }^{57}$ aponta algumas vivências de Lil Picard em que Hubert Fichte se vê refletido, como por exemplo a opressão no período do nacional-socialismo que, no caso de Lil Picard, resultou na emigração para os Estados Unidos da América. Rieger considera que traços em comum entre os dois artistas, como marginalização, perseguição e desenraizamento foram motivos para Fichte integrar essa biografia em seu projeto da "História da Sensibilidade", cuja concepção de literatura possui característica dialógica e polifônica.

\footnotetext{
55 EDWARDS, Kathleen. Lil Picard and the Counterculture of New York. Disponível em: uima.iowa.edu/lilpicard. Acesso em 25 maio 2016.

${ }^{56}$ FICHTE, Hubert. Die Schwarze Stadt (“A cidade preta”). Frankfurt am Main: S. Fischer Verlag, 1990.

57 RIEGER, Michael. Die Welt durch sich hindurch lassen: Hubert Fichtes Werk als Medium ästhetischer Erkenntnis. Frankfurt am Main: Peter Lang GmbH Internationaler Verlag der Wissenschaften, 2009: 186 - 188.
} 
Mühl, Nitsch e Lil Picard são relacionados por Fichte à cerimônia do banho de sangue em Xangô, ritual que ele define como chocante e atávico, realçando e ocidentalizando com respaldo no mundo da arte sua força, caracterizada principalmente por sua herança ancestral.

Schwarzsauer (sopa preta alemã Schwarzsauer) - É um prato feito à base de sangue animal, muito tradicional em partes do norte da Alemanha e antigamente também na Prússia oriental. Trata-se de uma sopa de sangue, feita com carne e sangue suínos, como forma de aproveitar todas as aparas ${ }^{58}$.

Lampion küsste keine Birken - provavelmente uma referência ao romance de Manfred Hausmann, "Lampioon küsst Mädchen und kleine Birken". A obra de 1928 narra as aventuras do vagante Lampioon pela Alemanha nos anos de $1920 . \mathrm{Na}$ narrativa, trata-se mais de reflexões sobre Deus, o mundo e as pessoas comuns desse mundo. Aos 15 anos, Lampioon mata um colega mais ou menos intencionalmente, motivado por uma mágoa típica da puberdade. O crime não é desvendado e ele muda de cidade e de emprego diversas vezes nos meses seguintes, até que ganha as estradas definitivamente e se transforma num andante ${ }^{59}$. Em Xangô, Fichte faz referência a Lampião, o cangaceiro que assombrou o nordeste brasileiro nas décadas de 1920 e 1930 e vivia igualmente uma vida nômade. No entanto, não possuía preocupações metafísicas, já que suas ações eram motivadas pela vingança da morte de seu pai, portanto, "não beijava bétulas".

Herman Miller Inc. - refere-se a uma fábrica de móveis de escritório, equipamentos e mobília para casa. Foi uma das primeiras empresas a produzir mobília moderna e abriu espaço para muitos designers modernos, que produziram peças que hoje são consideradas ícones do desenho industrial moderno ${ }^{60}$. Como

\footnotetext{
${ }^{58}$ SÖRGEL, Rita. Rübenmus und Schwarzsauer - oder: sie heiratet ja doch. Eine Kindheit und Jugend in der Kriegsund Nachkriegszeit in Kiel. Kiel: Armani International Publishing, 2009.

${ }^{59}$ SARKOWICZ, Hans; MENTZER, Alf (Org.). Literatur in Nazi-Deutschland. Ein biografisches Lexikon. Hamburgo, Viena: Europa Verlag, 2000.

${ }^{60}$ MILLER, Herman. Quem é a Herman Miller? Nossa história. Disponível em: hermanmiller.com.br. Acesso em 08 ago. 2016
} 
atento observador da cultura e do comportamento social, Hubert Fichte não pode deixar de notar o contraste entre o ambiente requintado e o tratamento conferido ao ser humano que frequenta a instituição bancária, nesse caso, uma senhora de idade.

Gastarbeiter (trabalhadores convidados). O termo "Gastarbeiter", ou trabalhadores convidados, remete-nos a um programa do governo alemão de recrutamento de trabalhadores que proviam principalmente da Turquia, da Grécia e de Portugal, para setores que não requeriam muita qualificação, como a linha de produção industrial. O termo foi aplicado em Xangô para designar um grupo de pessoas, em geral lavradores, que migram do norte do Brasil para o nordeste em busca de trabalho, mas que ali também encontra dificuldades devido à seca.

Die Legende von Franz von Assisi - conservação do nome em alemão, devido à referência ao santo italiano e uma de suas inúmeras lendas, como o bando de salteadores que se converteram devido à ação generosa dos monges que, seguindo as orientações de Francisco de Assis, começaram a Ihes oferecer vinho e alimentos ${ }^{61}$. Esse trecho finaliza a narração da história do bandido Francisco de Assis, perseguido e morto pela polícia. Fichte expõe a criminalidade como um fato social que, no sentido do sociólogo francês Émile Durkheim, é algo exterior ao indivíduo, uma consequência da desorganização social, da desagregação familiar, das condições econômicas e sociais em que vive o indivíduo (escassez de recursos econômicos, morando em favelas, ou nas ruas). A falta de oportunidade pode levar o indivíduo a encontrar na criminalidade seu meio de vida e sua única saída de sobrevivência.

\section{Im deutschen Märchen spielt der Junge auf den Knöchelchen seines Bruders.} (No conto de fadas alemão, o menino tocava os ossinhos de seu irmão.) Localizamos dois contos de fadas dos Irmãos Grimm em que aparecem os "ossinhos" como elemento-chave da trama: "João e Maria" e "O osso cantante". Esse último se aproxima mais da referência de Fichte, pois trata de um irmão invejoso que assassina seu irmão para ganhar uma recompensa. Anos mais tarde, um caçador encontra o osso do irmão morto e faz com ele uma flauta que começa a tocar sozinha e revela

\footnotetext{
${ }^{61}$ ZAMPIERI, Luigi. Histórias de São Francisco.

Disponível em: http://verbo-pai.blogspot.com.br/2012/10/historias-de-sao-francisco-de-assis.html. Acesso em 23 abr. 2017.
} 
toda a verdade. A descoberta do conto nos fez mudar a tradução de "brincava" para "tocava", pois o ossinho se transformou num instrumento musical. Quanto à interpretação, Hubert Fichte estaria atenuando o choque do uso de ossos com efeito sonoro que ele ouviu na cerimônia do axexê, como se emitisse a mensagem: não se trata de um hábito bárbaro e primitivo, na cultura europeia também há o registro de ossos (humanos) fora de seu contexto usual.

Caronte (em grego, Xápwv - o brilho) era uma figura mitológica do mundo inferior grego (o Hades) que transportava os recém-mortos na sua barca através do Aqueronte, rio que delimitava a região infernal, até o local no Hades que thes era destinado. Era costume grego colocar uma moeda, chamada óbolo, sob a língua do cadáver, para pagar Caronte pela viagem. Se a alma não pudesse pagar ficaria forçosamente na margem do Aqueronte para toda a eternidade, e os gregos temiam que pudesse regressar para perturbar os vivos. Uma alma penada sem rumo62.

Nixe (Nixie) - personagem da mitologia germânica e nórdica que vive nas águas e foi retomado pelos Irmãos Grimm em um conto. Uma famosa Nixie do folclore alemão do século XIX, a Lorelei, ficava sentada no topo de uma rocha do Reno e atraía com seu canto os pescadores e barqueiros para os perigosos recifes do local.

Cartacalo/la ${ }^{63}$ - pseudônimo de Otto Habermann, que se travestia de mulher para criar seus personagens femininos. Tornou-se conhecido por ter ocupado uma casa em uma colônia de jardins de Schreber, a "Vereinigung der Eimsbütteler Kleingärtner von 1919 e. V." ("Associação Registrada dos Pequenos Jardineiros de Eimsbüttel de 1919"), e lutou durante anos com as autoridades por ter desrespeitado a proibição de moradia permanente nesse lote. Como protesto, escreveu diversas cartas de reclamação e queixa, inclusive ao Papa, à Cruz Vermelha e ao chanceler Kiesinger. Habermann assinava os dois pseudônimos - Cartacalo e Cartacala - em suas correspondências, como se pode atestar em sua correspondência com Hubert

\footnotetext{
62 SPALDING, Tassilo Orpheu. Dicionário de Mitologia Greco-Latina.

63 FUHSE, Mario. Der Platz des „Platzes”: Gestalt und raumtheoretische Kontextualisierung zu Hubert Fichtes Roman Der Platz der Gehenkten. Hamburg: Männerschwarm Verlag, 2014.
} 
Fichte $^{64}$, que foi quem juntou as duas denominações e criou o nome bissexual Cartacalo/la, que ele utilizou em referências aos personagens de Otto Habermann em suas obras e em dois textos que escreveu sobre Cartacalo/la: Cartacalola und seine Zeit (Cartacalola e sua época - NHF 38.9) e Ein Abend mit Cartacalo/la. Ausstattungspossen mit Pressestimmen, Transvestiten und Schrebergärtnern (Uma noite com Cartacalo/la. Operetas burlescas com comentários da imprensa, travestis e jardineiros dos jardins Schreber). ${ }^{65}$

Schrebergartenkolonie - uma colônia de jardins de Schreber define-se como um grupo de lotes situados em terrenos públicos nas cidades ou à margem das ferrovias, arrendados pelos alemães para cultivar hortaliças, frutas e flores. Atualmente são utilizados também para lazer. A ideia foi introduzida há mais de 200 anos por um médico de Leipzig, Daniel Schreber, com o objetivo de proporcionar uma subsistência sustentável a uma população mais humilde, melhorando sua qualidade de vida e saúde.

Quirinus Kuhlmann (1651 - 1689) nasceu em Breslau (Silésia). É considerado uma das figuras mais originais do barroco literário alemão. Autor precoce de epigramas e epitáfios (1666) publicou aos 20 anos "Himmlische Libesküsse" (Beijos de Amor Celestes), conjunto de 50 sonetos, entre os quais o $41^{\circ}$, "Der Wechsel menschicher Sachen" (A Alternância das Coisas Humanas), exemplos de arte combinatória. Mais tarde vieram as duas séries de "Kühlpsalter" (1684-1686), 150 salmos que resumem a sua experiência de poeta visionário e extático. Foi denunciado na Rússia ao Czar como herege pelo patriarca da Igreja Ortodoxa, preso, torturado e, por não renegar suas crenças, condenado à morte e queimado vivo, em Moscou ${ }^{66}$. Em sua publicação intitulada "Mein Lesebuch" ("Meu livro de leitura"), Hubert Fichte reuniu os autores de obras que ele gostava de ler, que influenciaram seu trabalho e que ele queria divulgar. Nessa seleção encontram-se muitos autores barrocos, como Daniel Casper Lohenstein, Quirinus Kuhlmann, Hans Jakob Christoffel von

\footnotetext{
${ }^{64}$ Carta de Habermann a Fichte. In: NHF 27.2 (Espólio de Hubert Fichte)

65 FICHTE, Hubert. Alte Welt (Velho Mundo). Frankfurt am Main: S. Fischer Verlag, 1992. p. $458-548$.

${ }^{66}$ Comentários e tradução de poemas de Quirinus Kuhlmann por Augusto de Campos. REVISTA PROSA E VERSO. Disponível em: http://www.revistaprosaversoearte.com/quirinus-kuhlmann-poemas/. Acesso em 27 abr. 2017.
} 
Grimmelshausen e Andreas Gryphius. Seu interesse pelo Barroco literário teve início na época em que foi bolsista da Villa Massimo, em Roma, quando em 1967 conheceu o cientista literário Gustav René Hocke. Seus livros sobre o Maneirismo exerceram grande influência sobre Fichte. As escolas literárias que mais marcaram sua obra foram o Maneirismo (1560-1600), o Barroco (1600-1720) e a Empfindsamkeit (Sentimentalismo - 1720-1780). Desses movimentos, ele retira temas e procedimentos para o trabalho literário que desenvolveu. Nas tragédias de Lohenstein, por exemplo, Fichte descobre a utopia de uma república sem discriminação racial, em que as mulheres tinham igualdade de direitos, e na qual não havia restrições sexuais. Sobre a importância que atribui à literatura barroca alemã, segue a seguinte apreciação de Hubert Fichte: A literatura alemã é, para mim, a literatura barroca. Fantasia ortográfica, turbulência gramatical, a fúria pela formação (Bildung) e o frenesi regulatório - ela escapa para além da maioria das literaturas de sua época ${ }^{67}$.

Os três últimos comentários que tecemos acima (Cartacalo/la, Schrebergartenkolonie e Quirinus Kuhlmann) encontram-se juntos em um único parágrafo, no qual Hubert Fichte descreve a fala ininterrupta de C., o proprietário de um hotel barato de encontros de homossexuais, ao Ihes mostrar seu altar com os orixás. Por meio de analogias e associações, e como um auxílio à interpretação daquela vivência, ele recorre a lembranças da sua infância no bairro de Lockstedt, em Hamburgo, ao estilo literário de Quirinus Kuhlmann com sua arte combinatória, e uneos à realidade sociocultural e religiosa da Bahia. ${ }^{68}$

Menjoubart - A barba Menjou é a designação para um bigode fino, típico do ator de cinema estadunidense Adolphe Menjou (1890 - 1963). No período do macartismo, esse ator empenhou-se em eliminar as influências comunistas em Hollywood. Por isso, a barba Menjou foi usada pelo SED (Partido Socialista Unificado da Alemanha)

\footnotetext{
67 "Deutsche Literatur ist für mich barocke Literatur. Orthografische Phantasie, grammatische Turbulenz, Bildungsraserei und Lebenswut - sie zischt ab über die meisten Literaturen ihrer Epoche." FICHTE, Hubert. Mein Lesebuch. Frankfurt am Main: S. Fischer, 1976: 16.

68 RIEGER, Michael. Die Welt durch sich hindurch lassen: Hubert Fichtes Werk als Medium ästhetischer Erkenntnis. Frankfurt am Main: Peter Lang GmbH Internationaler Verlag der Wissenschaften, 2009: 141.
} 
na República Democrática Alemã durante a Guerra Fria como estereótipo para designar o ocidental com más intenções. ${ }^{69}$

\section{Questões lexicais}

As questões lexicais tiveram como principal orientação a preocupação com a literalidade. Na medida do possível, e para preservar a inteligibilidade, cuidamos para manter uma estreita ligação semântica com os vocábulos em alemão. A listagem abarca três partes. A primeira trata dos substantivos simples, com e sem prefixação, substantivos compostos, locuções, verbos com prefixação ou com um efeito onomatopaico, advérbios, adjetivos. A segunda engloba os termos de origem estrangeira, e a terceira, os nomes próprios. Para os comentários, fizemos uma seleção de algumas palavras listadas.

\subsection{Vocábulos de categoria gramatical variada}

\begin{tabular}{|l|l|}
\hline EM ALEMÃO & TRADUÇÃO \\
\hline Absteige (p. 7) & hotelzinho barato \\
\hline sich gründlich waschen (p. 7) & lavar-se completamente \\
\hline herantransportiert (p. 7) & transportadas para cá \\
\hline Unsauberkeit (p. 7 ) & não limpeza \\
\hline Kojen (p. 7) & leito \\
\hline Er hat Hunger. (p. 8 ) & Ele tem fome. \\
\hline Kammer (p.8 ) & Alcova \\
\hline Überwacht (p. 8) & Controlado \\
\hline erbarmungswürdig (p. 9) & digno de misericórdia \\
\hline Abflussrohre (p. 9) & canos de esgoto \\
\hline
\end{tabular}

${ }^{69} \mathrm{http}: / /$ www.duden.de/rechtschreibung/Menjoubart. Acesso em 20 nov. 2016. 


\begin{tabular}{|l|l|}
\hline verwilderter Garten (p. 9) & jardim asselvajado \\
\hline $\begin{array}{l}\text { Dass mir der Junge hier nicht } \\
\text { verwildert! (p. 10) }\end{array}$ & Que o menino aqui não se asselvage! \\
\hline Pelé (p. 16) & Pelé \\
\hline traumwandlerisch (p. 20) & Sonambulamente \\
\hline Chemismus (p. 21) & Quimismo \\
\hline (...) beim Drehen (p. 33) & (...) na rodagem do filme \\
\hline (...) brüllt vor Lachen (p. 33) & (...) ruge de rir. \\
\hline »Der Glöckner von Notredame« (p. & “O sineiro de Notredame” \\
\hline 37) & \\
\hline Psalmodieren (p. 40) & salmodiar \\
\hline Fotografiererei (p. 40) & fotografança \\
\hline Schwarzen (p. 48) & pretos (p. 48) \\
\hline Neger (p. 48) & negros (p. 48) \\
\hline Frass (p.10) & forragem \\
\hline versaut (p. 11) & emporcalhado \\
\hline abgezehrt (p. 11) & carcomido \\
\hline Tunte (p. 23) & maricas \\
\hline Trine (p. 23) & viadinho \\
\hline Unken unken. (p. 79) & Bombinhas ominam. \\
\hline Fröscheunken unken. (p. 79) & Rãsbombinas ominam. \\
\hline Unkenfrösche fröschen. (p. 79) & Bombinasrãs raneia. \\
\hline Weissblau (p. 89) & alviazul \\
\hline Der behandelde Arzt (...) (p. 99) & O médico medicante (...) \\
\hline Klares Wasser (p. 7) & água clara \\
\hline Blätter (p. 8) & folhas de notícias \\
\hline Baihanisch (p. 11) & bahianamente \\
\hline Ergriffensein (p. 21) & Ser-tomado \\
\hline Entkräften (p. 23) & retirar a força \\
\hline Metallarbeiter (p. 25) & \\
\hline (...) aus den Rippen schneiden (p. 55) tirar das costelas \\
\hline Blütenweissen Anzug (p. 103) & terno bro-florescente \\
\hline
\end{tabular}


Absteige - Encontramos as traduções albergue, pensão barata, motel, bordel, que são acepções da palavra utilizadas nos séculos XX e XXI. Por fim, optamos pela tradução "hotelzinho barato" em detrimento a pensão, pois "hotelzinho" contém um tom depreciativo do diminutivo.

sich gründlich waschen - poderia ser "se lavar bem", mas não transmite o significado profundo de "gründlich - auf den Grund gehen" ("genau und sorgfältig" = exatamente e com cuidado). Então, lavar-se completamente ${ }^{70}$.

herantransportiert $=$ transportadas para cá. Desmembramento do verbo composto, recuperação do prefixo heran (para cá, para perto do emissor da mensagem), marcando sua presença no lugar sobre o qual está narrando.

Unsauberkeit $=$ falta de limpeza, pelo desmembramento da palavra e tradução do sufixo un, que em composição com substantivo significa negação pelo advérbio "não" em alemão.

Kojen = cama estreita e embutida em barco ou navio; cama na linguagem coloquial; área em um cômodo maior, aberta em cima ou na frente e dividida por paredes provisórias, colocadas para uma determinada finalidade (DUDEN, 2017). Beliche, cama (Dicionário de Alemão-Português da Porto Editora). Optamos por leito na tradução, seguindo a terceira acepção do Duden quanto à divisão por paredes provisórias e por se assemelhar mais a camas de navios ou trens, estruturas mais toscas, sem a elaboração de uma cama.

Er hat Hunger = Ele tem fome, e não "ele está com fome", como na primeira tradução. "Ter" fica mais próximo do original e sugere uma permanência duradoura, diferente do verbo estar, que expressa estado provisório. Significa dizer, ele tem sempre fome.

\footnotetext{
${ }^{70} \mathrm{http}: / /$ www.duden.de/rechtschreibung/gruendlich. Acesso em 19. Apr 2016.
} 
überwacht (controlados) - A escolha do termo controlados e não monitorados reforça a ideia de repressão da ditadura.

Abflussrohre (canos de esgoto) - Chegamos a esse resultado por desmembramento da palavra composta. A primeira tradução foi "encanamento".

Verwilderten Garten = jardim asselvajado. O prefixo -ver + wild + desinência de verbo no particípio -ert resultam na palavra portuguesa -a -selvaj(em) -ado (prefixo de negação, adjetivo, desinência de particípio).

Pelé - a partir do último parágrafo da página 16, a menção ao nome Pelé referese ao mundialmente famoso jogador de futebol brasileiro. Anteriormente, Hubert Fichte narra a vida de Pelé, o empregado do comerciante de materiais de construção, que é explorado por seu patrão. A justaposição das duas figuras homônimas sugere uma crítica às injustiças e desigualdades sociais e raciais que ele observou e registrou na obra em questão. Em um mundo em que Xangô não faz justiça, segundo Fichte. Pelé, o futebolista, é apresentado pelo autor como o "álibi nacional preto da república brasileira", de uma sociedade que declara ser uma democracia racial.

“Der Glöckner von Notredame” - "O sineiro de Notredame" - Nossa opção pela tradução mais literalizante do título do filme contraria a tradução convencional "O corcunda de Notredame",

Psalmodieren (salmodiar) - seguimos o mesmo recurso utilizado em alemão, ou seja, a substantivação do verbo.

Fotografiererei (fotografança) - O sufixo '-rei' em alemão exprime algo realizado em excesso e, nessa acepção, pode corresponder ao sufixo '-ança' em português, como em comilança. Portanto, 'Fotografiererei' foi traduzida por 'fotografança'.

Schwarzen (pretos) - De acordo com o dicionário Duden, "Schwarzer/Schwarze" (preto/preta) designa alguém que tem uma pele (muito) escura. Acrescenta, numa observação, que a designação deve ser restrita a determinados contextos em que a cor da pele seja relevante (por exemplo, em recenseamentos). $O$ 
verbete ainda traz a informação de que as pessoas de pele escura que vivem na Alemanha escolhem normalmente a designação "Afrodeutscher/Afrodeutsche" (afroalemão/afroalemã), cada vez mais empregada na língua atual ${ }^{71}$.

Neger (negros) - O dicionário Duden define "Neger" como uma pessoa de pele (muito) escura. Observa, porém, que a designação deve ser evitada, pois é altamente discriminatória. Oferece como alternativa os termos "Schwarzer/Schwarze" (preto/preta), "Farbiger/Farbige" (de cor). Acrescenta ainda que as pessoas de pele escura que vivem na Alemanha escolhem normalmente a designação "Afrodeutscher/Afrodeutsche" (afroalemão/afroalemã), cada vez mais empregada na língua atual ${ }^{72}$. Hubert Fichte tinha consciência do uso politicamente correto dessas palavras, como podemos verificar na seguinte passagem de Explosion. Roman der Ethnologie (Explosão. Romance da etnologia) (1993:124): "Jäcki pensou, pretos, porque vem mais rápido ao raciocínio que africano, afro-americano"73. Ou ainda em outra passagem da mesma obra: "Porque ele só gosta de pretos" ${ }^{44}$ (1993:173), referindo-se à sua preferência sexual por homens pretos.

Frass (forragem) - A opção por "forragem" não por "ração" tem como objetivo intensificar a brutalidade do tratamento dado aos indivíduos.

versaut (emporcalhada) Essa escolha tradutória recupera a palavra alemã "die Sau", "a porca" e conserva o significado negativo.

Tunte - É a designação para u $\mathrm{m}$ homem homossexual ou um travesti que se destaca de outros homossexuais ou travestis por seu comportamento afetado. As "Tunten" se comportam de acordo com o estereótipo utilizado para se caracterizar um homossexual (por ex. em uma apresentação teatral). De acordo com a situação, a expressão pode ter uma descrição objetiva ou uma conotação ofensiva ${ }^{75}$. Optamos por traduzir como "maricas", termo

\footnotetext{
${ }^{71} \mathrm{http} / / / \mathrm{www}$. duden.de/rechtschreibung/Schwarzer. Acesso em 17. Apr 2016.

${ }^{72} \mathrm{http}: / /$ www.duden.de/rechtschreibung/Neger. Acesso em 17. Apr 2016.

73 "Jäcki dachte Schwarze, weil es sich schneller denken lie $\beta$ als Afrikaner, Afroamerikaner."

74 "Weil er nur noch auf Schwarze stand."

${ }^{75}$ http://www.mundmische.de/bedeutung/14515-Tunte. Acesso em 17. Apr 2016.
} 
informal e depreciativo para o homem que revela comportamento ou traços tradicionalmente associados ao gênero feminino ${ }^{76}$.

fröschen (ranear) - Introduzimos o verbo ranear como um neologismo em português, para sugerir o som e a ação das rãs na descrição da percepção auditiva do autor, por analogia com o verbo ranear no espanhol, que apresenta os seguintes significados: RANEAR ${ }^{77}$. Intr. Mover-se com ligeireza e agilidade. II Fazer contorções. II fig. vozear, divulgar, bradar, apregoar. II Dom. Intimidar, confundir. II Méx. Ler em coro e em voz alta, desordenadamente. II Difamar, caluniar. II Falar do que não se sabe.

Unken - substantivo (Bombina) = Bombina bombina é o nome científico de uma espécie de sapo-de-barriga-de-fogo endêmica da Europa continental, que está distribuída pela Europa Central e Oriental ${ }^{78}$.

unken - verbo (ominar) = predizer algo negativo, por pessimismo. Procuramos um verbo em português que exprimisse esse significado, e ao mesmo tempo formasse um conjunto sonoro com a palavra bombina. Encontramos um sinônimo de agourar, o verbo ominar, que em uma de suas acepções significa prenunciar ou ser sinal de $\operatorname{azar}^{79}$.

bahianisch (bahianamente) - Essa forma se aproximação da ortografia original e conserva a classe gramatical do advérbio com o sufixo - mente $=$-lich.

Ergriffensein (ser-tomado). Substituímos o termo "encorporação" pelo substantivo composto em português, criando um neologismo.

\footnotetext{
${ }^{76} \mathrm{http}: / /$ www.priberam.pt/dlpo/maricas). Acesso em 17. Apr 2016.

${ }^{77}$ RANEAR. intr. Moverse con ligereza y agilidad. II Hacer contorsiones. II fig. Vocear. II Dom. Apabullar, confundir. II Méx. Leer coreado y en alta voz, desordenadamente. II Infamar, calumniar. II Hablar de lo que no se sabe. (Disponível em: http://www.acanomas.com/Diccionario-Espanol/121043/RANEAR.htm. Acesso em 16 nov. 2016).

${ }^{78}$ http://dicionario.sensagent.com/Bombina\%20bombina/pt-pt/. Acesso em 16 nov. 2016.

${ }^{79}$ https://www.dicio.com.br/ominar/. Acesso em 16 nov. 2016.
} 
entkräften (retirar a força) - É o resultado do desmembramento do sufixo -ent, afastar, retirar + kräften, derivado de "Kraft".

herauskommen (sair para fora) - Embora se trate de um pleonasmo em português, justificamos a inclusão da expressão "para fora" para destacar o realce e a força do prefixo "heraus" no idioma de partida.

(...) aus den Rippen schneiden (tirar das costelas) - Não encontramos nenhuma expressão em português que utilizasse como referência as costelas para demonstrar o sentido de se tirar algo do nada. A imagem nos evoca a criação da mulher segundo o relato bíblico, que teria sido retirada da costela de Adão. A decisão por uma tradução mais literal se apoia na teoria de Antoine Berman ${ }^{80}$ sobre o etnocentrismo na tradução, em especial quanto à destruição das locuções pois, para o teórico, o ato de traduzir não significa a busca de equivalências, o que seria atentar contra a falância da obra.

Blütenweissen Anzug (terno branco-florescente) - Em consulta ao Duden, encontramos blütenweiß como sinônimo de strahlend weiß ("branco radiante") ${ }^{81}$. Com base nessa informação, criamos um neologismo em português pelo processo de composição. Assim, obtivemos de Blüte ("flor, florescência") a palavra florescente, que surgiu da derivação de florescência e significa em uma de suas acepções brilhante, notável. ${ }^{82}$

\subsection{Termos estrangeiros}

Os termos que têm origem em uma língua estrangeira ao português e alemão foram conservados em seu original, para garantir o efeito estrangeirizante. Eles se

\footnotetext{
${ }^{80}$ BERMAN, Antoine. A tradução e a letra, ou, O albergue do longínquo. Rio de Janeiro: 7Letras/PGET, 2007: 59 -60 .

${ }^{81}$ http://www.duden.de/rechtschreibung/bluetenweisz. Acesso em 30. Nov 2016.

82 https://www.dicio.com.br/florescente/. Acesso em 30. Nov 2016.
} 
encontram destacados em itálico na tradução. Selecionamos dois termos para os comentários, por terem causado dúvida na escolha tradutória.

\begin{tabular}{|l|l|}
\hline EM ALEMÃO & TRADUÇÃO \\
\hline Liftboy (p. 8) & Liftboy \\
\hline Understatement (p. 10) & Understatement \\
\hline de rigeur (p. 72) & de rigeur \\
\hline Boulevardzeitung (p. 69) & jornal de boulevard \\
\hline Passé (p. 43) & Démodé \\
\hline Faible (p. 114) & Faible \\
\hline
\end{tabular}

Boulevard (jornal de boulevard) - O termo Boulevardzeitung, que traduzimos por jornal de boulevard, define um tipo de jornal produzido para ser vendido ou distribuído nas ruas, nas bancas, sem a opção de assinatura, ou abbonement. Para que estes jornais vendidos nas ruas conquistassem a atenção dos transeuntes para a sua compra, acabaram por incorporar características sensacionalistas aos seus textos, grafismos e fotografias ${ }^{83}$. Primeiramente traduzimos por tabloide, somente mais tarde, com o exercício de um olhar tradutório diferenciado, optamos por dividir a palavra composta do alemão e conservar o termo estrangeiro.

Passé (fora de moda, ultrapassado) - Palavra estrangeira emprestada do francês. Optamos por um outro estrangeirismo, pelo adjetivo francês démodé, que carrega o mesmo sentido, ou seja, é o que está fora de moda, antiquado, obsoleto ${ }^{84}$.

\subsection{Conservação de nomes próprios}

\footnotetext{
83 revista.uniabeu.edu.br/index.php/RU/article/download/615/pdf_264. Acesso em 6 nov. 2016.

${ }^{84}$ http://www.priberam.pt/dlpo/d\%C3\%A9mod\%C3\%A9. Acesso em 03 ago 2016.
} 
Christiane Nord (2003) afirma que os nomes próprios no mundo real podem ser não descritivos, porém têm várias funções, a principal é informativa. Cita alguns casos em que o um substantivo genérico indica o referente e forma uma parte do nome, como Mount Everest. Se a referência for incompreensível para o leitor que não conheça a língua, isso pode causar problemas de tradução. Em nosso contexto, os nomes que escolhemos para listar abaixo possuem em sua maioria um referente ou uma forma muito semelhante à designação em português, o que auxilia em sua identificação e no cumprimento da função informativa. Por esse motivo e para dar visibilidade ao tradutor, conservamos os nomes como no texto-fonte.

\begin{tabular}{|l|l|}
\hline EM ALEMÃO & TRADUÇÃO \\
\hline Vila America (p. 13) & Vila America \\
\hline Krankenhaus Las Clinicas (p. 59) & Hospital Las Clinicas \\
\hline Correo da Manha (p. 8) & Correo da Manha \\
\hline Irece (p. 55) & Irece \\
\hline Feira Sant'Ana (p. 54) & Feira Sant'Ana \\
\hline
\end{tabular}

\section{Frases da ditadura}

As notas a seguir se referem a slogans da propaganda da ditadura militar brasileira na década de 1970 e foram traduzidos de memória, pela nossa vivência daquele momento histórico-político. Eram divulgadas por vários meios como adesivos, canções e futebol, e tinham o objetivo de conclamar o povo a aderir e aprovar o sistema imposto ${ }^{85}$. Essas frases de propaganda ufanista eram uma tendência mundial da época. O slogan "Brasil - ame-o ou deixe-o" foi copiado de campanha do governo

\footnotetext{
${ }^{85}$ http://falandodeteologiaehistoria.blogspot.com.br/2012/01/propaganda-politica-do-governo-medici.html. Acesso em 16. Apr 2016.
} 
de Richard Nixon, veiculada em 1968 nos Estados Unidos: "America, love it or leave it"86.

\begin{tabular}{|l|l|}
\hline EM ALEMÃO & TRADUÇÃO \\
\hline Brasilien - lieb oder lass es. (p. 15) & Brasil - ame-o ou deixe-o. \\
\hline Ich liebe dich, mein Brasilien. (p. 15) & Eu te amo, meu Brasil. \\
\hline $\begin{array}{l}\text { Niemand kann dieses Land mehr } \\
\text { bremsen. (p. 15) }\end{array}$ & Ninguém segura este país. \\
\hline
\end{tabular}

Brasilien - lieb oder lass es. - Brasil - ame-o ou deixe-o. Esses slogans fizeram parte de uma das campanhas publicitárias do governo Médici iniciada no Brasil em abril de 1970, o ano da copa, incentivando o nacionalismo. Eram adesivos fixados em para-choques e para-brisas dos carros

Ich liebe dich, mein Brasilien. - Eu te amo, meu Brasil. Esse é também o título de uma canção composta pelo cantor Dom, da dupla brasileira Dom \& Ravel, que fez sucesso nos primeiros anos da década de 1970. A música tornou-se muito conhecida nos anos 70 por sua interpretação pela banda "Os Incríveis" 87.

Niemand kann dieses Land mehr bremsen. (Ninguém segura este país) - Esse slogan representa o ápice da campanha do governo do general Emílio Garrastazu Médici veiculada pela TV na década de 1970 para plantar o otimismo no ânimo dos brasileiros e criar uma atmosfera de satisfação com o Golpe de 1964. A informação de que a situação no país alcançava progressos positivos foi reforçada com a vitória da seleção brasileira de futebol na Copa do Mundo de 1970, a primeira tricampeã mundial. O fato criou na população um clima de euforia, de que não havia mais impedimentos para o desenvolvimento e prosperidade do povo brasileiro.

\footnotetext{
${ }^{86}$ http://memoriasoswaldohernandez.blogspot.com.br/2012/10/historia-dos-anos-70 27.html. Acesso em 16. Apr 2016.

${ }^{87}$ http://www.dicionariompb.com.br/dom--ravel/dados-artisticos. Acesso em 16 de abril de 2016.
} 


\section{Questões relacionadas ao universo da religião - identidade}

Optamos por traduzir todas as palavras referentes ao campo lexical religioso do candomblé para preservar a seu caráter de identidade e resistência cultural afrobrasileira. Para tanto, encontramos embasamento teórico em CASTRO (2005: 80), quando define língua-de-santo como

mais um veículo de expressão simbólica do que propriamente de competência linguística. O seu uso é circunscrito a um sistema lexical de base africana relacionado ao universo religioso dos recintos sagrados, onde se desenrolam as cerimônias do culto e, já modificado, em sua origem, pela interferência da língua portuguesa no Brasil".

Quanto à importância do campo lexical culinário no contexto religioso, encontramos respaldo em LODY (1998: 25), segundo o qual "a convenção de comer surge da necessidade de nutrição e sobrevivência, o que não anula os significados simbólicos de cada prato, tipos de ingredientes, espaços de feitura e de oferecimento".

Nossos comentários contemplam apenas algumas designações listadas na tabela abaixo, e a escolha pautou-se pela relevância que apresentam para uma discussão da obra Xangô.

\begin{tabular}{|l|l|}
\hline EM ALEMÃO & TRADUÇÃO \\
\hline Xango (capa, título) & Xangô \\
\hline Nago (p. 12) & Nagô \\
\hline Oxumare (p. 13) & Oxumaré \\
\hline Meneninha de Gantois (p. 23) & Menininha de Gantois \\
\hline Logum Ede (p. 32) & Logum Edé \\
\hline Yoruba (p. 33) & lorubá \\
\hline Oga (p. 36) & Ogã \\
\hline Axexe (p.61) & Axexê \\
\hline Makulele (p. 92) & Maculelê \\
\hline Vatapa (p. 10) & Vatapá \\
\hline Kalulu (p. 10) & Carurú \\
\hline Efo $($ p. 10) & Efó \\
\hline Kele $($ p. 22) & quelê \\
\hline
\end{tabular}


Xango (Xangô) - Xangô é um orixá iorubano, deus do raio e do trovão, filho de lemanjá e Oraniã. De acordo com a mitologia, foi fundador e quarto rei da cidade de Oió, o mais poderoso império iorubá. Possuiu três esposas: Oiá (rio Níger), no Brasil, denominada lansã, Oxum e Obá, sendo as duas últimas orixás dos rios desses nomes. No sincretismo religioso afro-brasileiro, foi associado a São Jerônimo ambos têm sua festa comemorada no dia 30 de setembro. Cada orixá tem uma ou mais cores, cuja vibração se harmoniza com a sua. As cores de Xangô são o vermelho e o branco ${ }^{88}$.

Xangô é um orixá guerreiro, característica demonstrada em seus vários mitos. Cultuado como a divindade iorubana da justiça, carrega um machado duplo representando o equilíbrio das forças. Seu símbolo por excelência é a pedra-de-raio, o santuário guardião das esperanças das pessoas que sofrem devido a desemprego, falta de oportunidades, incompreensão e obstáculos no trabalho, escassos meios de sobrevivência, perseguição, inveja e complicações legais. Os devotos apelam a Xangô, em busca de fortalecimento para suportar ou solucionar suas dificuldades. De um modo geral, esse orixá protege todos que se sentem injustiçados em diversos âmbitos da vida.

O império de Oió englobava as mais importantes cidades do mundo iorubá, e de lá o culto a Xangô foi difundido por todo o território iorubano, algo excepcional, já que na época cada cidade ou região tinha os seus próprios orixás. Oió dispunha de uma expressiva força militar, que por muito tempo protegeu os iorubás de invasões inimigas e impediu que seu povo fosse caçado e vendido por outros africanos ao tráfico de escravos destinado às Américas. Com a destruição do poderio de Oió, os povos iorubás se tornaram vulneráveis à caça e presa fácil para o mercado de escravos. Nessa época, o Brasil e outros países americanos passaram a receber escravos iorubás, que vinham de diferentes cidades, cultuavam diferentes deuses, falavam dialetos distintos, porém todos tinham em comum o culto ao orixá Xangô. Daí se origina a importância que Xangô ocupa nas religiões africanas nas Américas no século XIX. Os escravos recém-chegados não ficam mais dispersos, distribuídos nas plantações e nas minas do interior, mas iam para as cidades e viviam em bairros com

${ }^{88}$ CACCIATORE, Olga Gudolle. Dicionário de Cultos Afro-brasileiros. Rio de Janeiro: Editora Forense-Universitária, 1977. 
grande concentração de negros escravos e libertos, organizando-se em irmandades católicas, com oportunidades de recriar aqui a sua religião africana. Assim, o primeiro templo iorubá da Bahia surgiu da iniciativa de negros iorubás da irmandade religiosa da igreja da Barroquinha, em Salvador e foi dedicado a Xangô. Até hoje, símbolos exclusivos do culto a Xangô na África foram generalizados no Brasil para o culto de todos os orixás, como o uso do colar ritual de iniciação chamado quelê.

Na América Central, em especial no Caribe, a palavra xangô também dá nome à religião dos orixás praticada em Trinidad-Tobago. Essa designação ocorre igualmente entre populações americanas de origem caribenha na costa Atlântica do sul dos Estados Unidos. A religião afro- americana que se desenvolveu em Cuba, a santeria, também apresenta indícios do domínio ritual de Xangô ${ }^{89}$.

Em Xangô. As religiões afro-americanas. Bahia, Haiti, Trindad, Hubert Fichte nos apresenta suas observações e impressões sobre três cultos: o candomblé na Bahia, o vodu no Haiti e o culto de Xangô em Trinidad. Essa obra, bem como Xangô. As religiões afro-americanas. Bahia, Haiti, Trindad II, que traz as fotos da fotógrafa alemã Leonore Mau, são frutos de uma viagem de pesquisa que ambos empreenderam nesses países. Consideramos importante inserir nesse trabalho a nota sobre Xangô, tanto para expandir a compreensão do texto, como para indicar que Fichte estudou a fundo o assunto e sabia sobre o que estava falando. A escolha do orixá Xangô para dar título às obras não se deve somente ao fato exposto acima, de como o culto desse orixá se espalhou nas Américas, mas também à preocupação de Fichte com as questões sociopolíticas, ou seja, a miséria e a ditadura militar que oprimiam boa parte da população brasileira daquela época, o subproletariado, como ele mesmo definiu.

Meneninha de Gantois (Menininha do Gantois - 1894 -1986) - Mãe Menininha do Gantois foi como ficou conhecida Escolástica da Maria da Conceição Nazaré, grande líder espiritual do terreiro do llê lya Omin Axé lyamassê, mais conhecido como terreiro do Gantois (nome do antigo proprietário francês do terreno). As mulheres de sua família iniciaram Menininha nos segredos da religião africana e preparam-na para o cargo de ialorixá (mãe-de-santo, na língua ioruba). Foi homenageada por amigos e 
artistas em vida. Dentre essas homenagens, a mais conhecida é a música "Oração a Mãe Menininha", que Dorival Caymmi compôs em 1972 ${ }^{90}$. Mãe Meninha do Gantois morreu com 92 anos. Fichte (1976:23) menciona algo sobre o enterro da mãe de santo, como um costume cultural religioso bastante peculiar, que possuiu uma coreografia própria e exige o envolvimento total de quem o acompanha.

Axexe (axexê) - O axexê é uma cerimônia ritual fúnebre do candomblé, celebrada quando morre alguém importante da comunidade religiosa, como o chefe, um filho de santo ou um ogã. Tem origem nas tradições iorubá e sua finalidade é libertar a alma da matéria e a alma do morto e passá-la da existência individual para a existência genérica, no mundo espiritual. O axexê começa após o enterro e consta de rituais diversos, de cânticos e danças. Costuma durar de três a sete dias, dependendo do grau de importância do morto na hierarquia do candomblé ${ }^{91}$.

A cerimônia do axexê aparece em Xangô na narração desse ritual fúnebre dedicado Joãozinho da Goméia, famoso sacerdote do candomblé. Hubert Fichte conta a história de Joãozinho em flash back, a partir de relatos de Gisèle Cossard Binon, ou Mãe Gisele de lemanjá, uma mãe de santo francesa e doutora em candomblé pela Universidade Paris-Sorbonne, orientanda de Roger Bastide. Gisele conheceu Joãozinho da Goméia na década de 1960 no terreiro dele, e ali experimentou o seu primeiro estado de transe. A transcrição da entrevista concedida por Gisele a Hubert Fichte encontra-se no livro Etnopoesia. Antropologia das religiões afro-americanas (1987).

Kalulu (carurú) - O carurú feito somente à base de quiabos é também chamado de amalá, a comida votiva de Xangô. Os quiabos, após lavados e enxutos, são cortados, temperados com cebola ralada, pimenta, coentro e sal, misturados a camarão seco, descascados e moídos. São cozidos com pouca água, um pouquinho de limão e azeite de dendê. A comida no candomblé possui significado simbólico, ou

\footnotetext{
${ }^{90} \mathrm{https}$ ///educacao.uol.com.br/biografias/mae-menininha-do-gantois.htm. Acesso em 05. Mai 2017.

${ }^{91}$ CACCIATORE, Olga Gudolle. Dicionário de Cultos Afro-brasileiros. Rio de Janeiro: Editora Forense-Universitária, 1977.
} 
seja, oferecer um amalá a Xangô significa fortalecer a sua força vital, além de fazer pedidos de proteção ao orixá92.

\section{Títulos de jornais, revistas etc.}

Hubert Fichte recolhe uma parte das informações sobre os acontecimentos sociais e políticos da época em que viveu na Bahia de jornais e revistas, e utiliza o recurso da colagem para compor seu texto. Segundo informações que ele obtém de um redator, os militares tinham a imprensa completamente em suas mãos e praticavam largamente a censura nos meios de comunicação e artístico. Declara ainda que $\mathrm{O}$ Correio da Manhã (Correo de Manha) seria um dos poucos jornais independentes no país.

\begin{tabular}{|l|l|}
\hline EM ALEMÃO & TRADUÇÃO \\
\hline Correo de Manha (p. 8) & Correo de Manha \\
\hline »Die Welt « (p. 11) & "Welt « \\
\hline A Tarde (p. 12) & A Tarde \\
\hline Deutsche Reportagefilm & Deutsche Reportagefilm \\
\hline O Cruzeiro (p. 49) & O Cruzeiro \\
\hline Jornal do Brasil (p. 72) & Jornal do Brasil \\
\hline $\begin{array}{l}\text { Die Wochenschau von Carlos } \\
\text { Niemeyer (p. 37) }\end{array}$ & $\begin{array}{l}\text { O jornal semanal de Carlos } \\
\text { Niemeyer }\end{array}$ \\
\hline
\end{tabular}

Correo de Manha - O Correio da Manhã foi um periódico brasileiro, publicado no Rio de Janeiro, de 1901 a 1974. Fundado por Edmundo e Paulo Bittencourt, vangloriava-se por dar ênfase à informação em detrimento da opinião. Caracterizouse por fazer oposição a quase todos os presidentes brasileiros no período, razão pela

\footnotetext{
${ }^{92}$ CACCIATORE, Olga Gudolle. Dicionário de Cultos Afro-brasileiros. Rio de Janeiro: Editora Forense-Universitária, 1977.
} 
qual foi perseguido e fechado em diversas ocasiões, e os seus proprietários e dirigentes, presos $^{93}$.

“Die Welt" (“O Mundo") é um jornal alemão de circulação em todo o país e ideologia conservadora. Foi fundado em Hamburgo em 1946 pelas forças de ocupação britânicas e sua sede atual situa-se em Berlim ${ }^{94}$. Em Xangô, o jornal alemão aparece na fala de um conterrâneo de Hubert Fichte, declarando que recebe a edição do "Die Welt" regularmente por via aérea, o que consideram um privilégio. Fichte acrescenta essa fala a outras declarações etnocêntricas de alemães e outros estrangeiros vivendo no Brasil.

A Tarde - jornal fundado em Salvador em 1950, de ideologia esquerdista nos últimos vinte anos ${ }^{95}$.

Jornal do Brasil: jornal brasileiro fundado em 1891 no Rio de Janeiro. Conforme o jornalista Jânio de Freitas, o Jornal do Brasil foi o principal jornal durante o regime militar, beneficiando-se ao identificar-se com o regime. Liderou iniciativas de apoio ao regime, utilizando expressões como "milagre brasileiro", "Brasil grande" 96.

Tribuna da Bahia: fundado em 1969, o jornal circula no estado da Bahia, e é atualmente o terceiro jornal mais importante do estado, ficando atrás do diário $\underline{A \text { Tarde }}$ e do Correio da Bahia. ${ }^{97}$.

O Cruzeiro: Revista semanal ilustrada, lançada no Rio de Janeiro no ano de 1928, editada pelos Diários Associados, de Assis Chateaubriand. Foi a principal revista ilustrada brasileira da primeira metade do século XX. Estabeleceu uma nova linguagem na imprensa brasileira: inovações gráficas, publicação de grandes reportagens, ênfase ao fotojornalismo ${ }^{98}$.

\footnotetext{
93 arquivonacional.gov.br/acervos-mais-consultados-titulo/correio-da-manha.html. Acesso em 05. Mai 2016.

${ }^{94}$ zeitung.Welt.de. Acesso em 15. Apr 2016.

${ }^{95} \mathrm{http}$ ://www.politicalivre.com.br/2015/10/milhoes-e-lagrimas-na-venda-do-jornal-a-tarde/. Acesso em 15. Apr 2016.

${ }^{96}$ RIBEIRO, Belisa. Jornal do Brasil. História e Memória. Rio de Janeiro: Record, 2015. Acesso em 19. Apr 2016.

${ }^{97}$ FERRAZ, Alex. Tribuna 40 anos de Bahia. Salvador: Bamboo Editora, 2010. Acesso em 19. Apr 2016.

${ }^{98}$ SCALZO, Marília. Jornalismo de Revista. São Paulo: Contexto, 2003. Acesso em 19. Apr 2016.
} 
Die Wochenschau von Carlos Niemeyer - referência ao Canal 100, um famoso cinejornal brasileiro fundado em 1957 por Carlos Niemeyer, inicialmente com o nome "Líder Cinematográfica", que funcionou até 2000. Com sede no Rio de Janeiro, o cinejornal era exibido semanalmente por todo o Brasil e realizava principalmente documentários cinematográficos de eventos importantes do país e do futebol ${ }^{99}$.

Com o presente capítulo, encerramos os comentários que selecionamos para demonstrar o caminho que percorremos em nosso processo de tradução e também para possibilitar ao leitor uma melhor aproximação e interpretação do texto, respeitando o texto de partida e preservando ao máximo suas características formais e semânticas, sem o recurso da facilitação.

No próximo capítulo teceremos as considerações finais, elaborando uma síntese da trajetória nos trabalhos de tradução e pesquisa, e avaliando a ligação entre a proposta inicial e os resultados alcançados.

\footnotetext{
99 BELÉM, Euler França. Canal 100, a voz dos militares e o futebol como você nunca viu, 2015. In: Jornal Opçao 41 anos. Disponível em: jornalopcao.com.br. Acesso em 28 mai. 2016
} 


\section{CONSIDERAÇÕES FINAIS}

O processo de leitura empreendido pelo tradutor no desempenho de seu mister faz dele um leitor especial. Retomando as reflexões de Paulo Rónai (1976) acerca do assunto, o trabalho de tradução proporciona e requer o saborear de cada palavra e a leitura nas entrelinhas, o que conduz o tradutor a um conhecimento mais profundo do autor e de seu estilo.

As afirmações acima nos remetem a uma pergunta central colocada no capítulo IV, dedicado aos comentários à tradução: em que medida a estratégia de tradução eleita contribui para dar a conhecer a obra a leitores brasileiros? O que, na verdade, essa estratégia dá a conhecer para além de um "mero" conteúdo? Para responder tal questão, foi necessário seguir os passos estabelecidos nos objetivos iniciais a serem alcançados nesse trabalho. No capítulo II expusemos a moldura teórica escolhida. Trata-se de um referencial baseado em Schleiermacher (1813) e atualizado por Venuti (1995) e Berman (2007), com propostas que sugerem uma alternativa tradutória estrangeirizante, ou seja, que proporciona no idioma de chegada um distanciamento do leitor em relação ao texto lido, e por outro lado, a estratégia da domesticação, que aproxima o leitor do autor por meio da facilitação do texto e torna o texto de chegada fluente.

Na presente dissertação, a opção foi feita pela estrangeirização, atitude que atribui visibilidade ao tradutor, e seguindo essa linha, trabalhamos o texto de chegada no sentido de reconstruir estruturas sintáticas e de optar por escolhas lexicais que transmitissem o maior grau de literalidade possível e aproximassem o leitor do idioma de partida. Partindo da perspectiva de quem traduz, e com base no conceito de reescrita de Lefevere (1992), na acepção de que as reescritas servem para introduzir novos conceitos, gêneros e recursos, promovendo a inovação literária e incentivando o poder formador de uma cultura sobre a outra, adotamos uma atitude recriadora da escrita fichteana, que mantivesse as características do texto-fonte e a marca poética na análise etnográfica. 
Nesse exercício, não nos descuidamos, no entanto, da inteligibilidade do texto. Para atingir esse objetivo, buscamos respaldo teórico em Nord (2001), cuja abordagem de tradução se apoia em dois pilares: o funcionalismo e a lealdade. $O$ primeiro requer que o texto cumpra a função de, neste caso, provocar reações de desconforto nos receptores da cultura de chegada, por meio da descrição de uma realidade dura e impiedosa. Já a lealdade, segundo a autora, deve levar em consideração as intenções e expectativas de todos os parceiros na interação comunicativa, que neste caso é a tradução. Segundo Nord, trata-se de uma atitude que leva em conta um relacionamento entre pessoas e, nesse sentido, envolve o tradutor em uma malha de responsabilidades a serem assumidas tanto com a constelação de fatos e pessoas do ambiente de partida, quanto do de chegada.

Desse modo, trilhamos um caminho intermediário, buscando um equilíbrio pautado pelo bom senso entre a estratégia de estranhamento e uma aproximação do idioma e da cultura de chegada e demonstrando o que realmente acontece na situação empírica da prática da tradução. Nesse sentido, buscamos nos alinhar com Britto (2012:62). Para o autor, ao se referir às estratégias tradutórias de estranhamento e facilitação, ele declara que, em sua experiência como tradutor, aprendeu que as duas estratégias apresentadas no texto seminal de Schleiermacher constituem no ato tradutório um par de ideais absolutos inatingíveis, pois o que na realidade se faz, é adotar posições intermediárias entre dois extremos.

Como as anotações de Hubert Fichte são resultado de observações movidas por uma percepção sensível do Outro, do Estranho, procuramos utilizar a tradução também como um exercício de análise e crítica da obra, bem como de sensibilização crítica do leitor. Nesse contexto, ganharam um grande espaço as referências teutoeuropeias que, devido à sua ancoragem na cultura de origem e nas vivências do autor, foram utilizadas pelo autor para interpretar suas novas experiências e auxiliaram o tradutor na análise da obra e de sua imbricação com dados biográficos de Hubert Fichte, cuja moldura já havia sido introduzida no capítulo I. Essas considerações, bem como as questões sintáticas e lexicais, foram desenvolvidas no capítulo IV. Entendendo a tradução como um espaço de provocação e reflexão crítica, a presente proposta de tradução com notas e comentários, e com a intenção de causar um estranhamento no leitor, encontra meio profícuo no ambiente acadêmico. 
Sabemos, contudo, que esta não é a estratégia predominante no meio editorial. E se pretendemos que a tradução aqui realizada não se restrinja a um determinado público - o acadêmico - e alcance outros leitores, todo o material desenvolvido nesta pesquisa precisaria ser reorganizado: em primeiro lugar, uma nota prévia à tradução explicaria a estratégia adotada. Em segundo, o trabalho de pesquisa que resultou nos comentários poderia compor um apêndice ou posfácio, voltado ao interesse daqueles que quisessem complementar seus conhecimentos e retraçar as ligações entre o texto que leem e as múltiplas referências de que Fichte lança mão para transformar o estrangeiro e exótico em algo mais familiar e compreensível para si. Azenha Junior (2010: 60) aborda a questão das notas explicativas inseridas no discurso literário que, segundo um consenso, destroem a dimensão ficcional da obra, por remeter o leitor ao plano da metalinguagem. Essa reestruturação da apresentação da tradução e de suas notas e comentários colocaria em evidência as estratégias de transparência associadas à conquista de espaço da visibilidade do tradutor, mas sem interferir diretamente no encontro do leitor com o texto.

Pensando no futuro, esta pesquisa certamente abre portas para muitos desdobramentos. Um deles seria a continuidade da tradução para os dois outros capítulos que compõem a obra Xangô. As religiões afro-americanas. Bahia, Haiti, Trinidad, ou seja: Haiti e Trinidad. Pautada por uma estratégia de tradução análoga, a trilogia seria antecedida de um breve estudo sobre o autor e a obra (um texto resultante da fusão dos capítulos I e IV desta pesquisa), as traduções apresentadas em edição bilíngue, precedidas de uma nota prévia, conforme mencionado acima, e seguidas de um conjunto de notas resultantes da pesquisa atinente às múltiplas relações entre a obra, seu entorno e seu autor, conforme mencionamos acima.

Outro campo aberto à continuidade desta pesquisa envolvendo as obras de Fichte e que traria uma contribuição aos Estudos da Tradução encontra-se nos trabalhos do autor em parceria artística com Leonore Mau. Refiro-me, em especial, à primeira edição de Xangô (1976), acompanhada do livro fotográfico de Leonore Mau, que registrou em imagens o relato de viagem e a leitura etnográfica. Trata-se da investigação do entrelaçamento entre a linguagem fotográfica e a literária, que dialogam e se complementam o tempo todo. Segundo BRAUN (1997), essa obra de documentação dupla, única em sua envergadura na história da literatura e da 
fotografia, ainda não mereceu a atenção devida na recepção de Hubert Fichte. Naturalmente, tal projeto envolveria uma moldura teórica e uma metodologia diferentes das adotadas neste trabalho, com intersecções para domínios conexos como o da Semiótica, tudo isso dentro de um conceito amplo de tradução intersemiótica, para usar o termo de Jakobson (1959).

Para finalizar, gostaria de registrar um brevíssimo depoimento sobre o modo como o exercício de tradução proposto neste trabalho alterou a minha própria concepção de tradução e do traduzir. Como tradutora juramentada para o alemão, tenho que assumir uma atitude tradutória de explicitação, assegurando que a linguagem dos textos traduzidos, em geral documentos pessoais e escolares, que devem ser apresentados a um órgão público, seja a mais clara e precisa possível, a fim de que cumpra sua função comunicativa, sem deixar dúvidas. Já o trabalho com a tradução literária requer mais liberdade criativa, em especial quando se adota a postura de trazer o leitor até o autor que se está traduzindo, para colocá-lo em contato direto com o elemento estrangeiro, sem recursos de facilitação. Dois fatores conjugados, as reflexões proporcionadas pelo estudo de Teorias da Tradução e o transitar na prática entre dois modos de tradução - a juramentada e a literária contribuíram para a expansão da minha competência tradutória e para o desenvolvimento de uma atitude mais consciente no desempenho dessa atividade. 


\section{REFERÊNCIAS BIBLIOGRÁFICAS}

\section{TEXTO DO CORPUS}

FICHTE, Hubert. Xango. Die afroamerikanischen Religionen. Bahia. Haiti. Trinidad. Frankfurt am Main: S. Fischer, 1984.

\section{OUTRAS OBRAS CONSULTADAS DE HUBERT FICHTE}

FICHTE, H. Detlevs Imitationen »Grünspan«. Frankfurt am Main: S. Fischer, 1971.

. Versuch über die Pubertät. Frankfurt am Main: S. Fischer,1974.

. Mein Lesebuch. Frankfurt am Main: S. Fischer, 1976.

. Der Platz der Gehenkten. Frankfurt am Main: S. Fischer, 1985.

- Etnopoesia. Antropologia poética das religiões afroamericanas. Organização e prefácio de Wolfgang Bader. Seleção de Hubert Fichte e Wolfgang Bader. Tradução de Cristina Alberts e Reny Hernandes. São Paulo: Brasiliense, 1987.

1991.

. Die Schwarze Stadt. Glossen. Frankfurt am Main: S. Fischer Verlag, Alte Welt. Glossen. Frankfurt am Main: S. Fischer Verlag, 1992.

Explosion. Roman der Ethnologie. Frankfurt am Main: S. Fischer, 2006

\section{LIVRO FOTOGRÁFICO DE LEONORE MAU}

MAU, Leonore. Xango. Die afroamerikanischen Religionen. Bahia, Haiti, Trinidad. Texte Hubert Fichte (Xango. As religiões afro-americanas. Bahia. Haiti. Trindad). Frankfurt am Main: S. Fischer, 1976.

\section{ESTUDOS DA TRADUÇÃO}

AZENHA JUNIOR, J. (2010). "Transferência cultural em tradução: contextualização, desdobramentos, desafio". TradTerm, v. 16, p. 37-66.

BERMAN, Antoine. A tradução e a letra ou o albergue do longínquo. Rio de Janeiro: 7Letras/PGET, 2007. 
BATTISTI, Patrícia Stafusa Sala. A crítica de tradução em Antoine Berman: reflexo de uma concepção antietnocêntrica da tradução. Campinas, 2000. Dissertação (Mestrado em Línguistica Aplicada) - Instituto de Estudos da Linguagem, Universidade Estadual de Campinas.

BOTELHO, José Rodrigo da Silva. Um encontro com Anna Seghers: tradução, insubordinação, criatividade e a presença do fremd. São Paulo, 2012. Dissertação (Mestrado em Língua e Literatura Alemã) - Faculdade de Filosofia e Ciências Humanas, Universidade de São Paulo.

BRITTO, Paulo Henriques. A tradução literária. Rio de Janeiro: Civilização Brasileira, 2012.

EMMERICH, Karen. "Visibility (and invisibility)." In: Handbook of Translation Studies, Volume 4 (2013, pp. 200-206) | DOI: 10.1075/hts.4.vis1

LEFEVERE, André. Translation, rewriting, and the manipulation of literary fame. New York: Routledge, 1992.

MARTINS, Marcia do Amaral Peixoto. "As contribuições de André Lefevere e Lawrence Venuti para a Teoria da Tradução". Caderno de Letras (UFRJ), n. 27, dez./2010, p. 59-72. Disponível em:

http://www.letras.ufri.br/anglo germanicas/cadernos/numeros/122010/textos/cl 301220100marcia.pdf. Acesso em 25 jun. 2014

MOREIRA, Marcelo Victor de Souza. Estudos Funcionais da Tradução: rupturas e continuidades. 253f. Dissertação (Mestrado em Língua e Literatura Língua e Literatura Alemã) - FFLCH, USP, São Paulo, 2014.

NORD, Christiane. "Loyalität statt Treue. Vorschläge zu einer funktionalen Übersetzungstypologie". In: Lebende Sprachen 34 (1989), Nr. 3, 100-105.

PALOPOSKI, Outi. "Domestication and foreignization." In: Handbook of Translation Studies, Volume 2 (2011, pp. 40-42) | DOI: 10.1075/hts.2.dom1

RÓNAI, Paulo. A tradução vivida. Rio de Janeiro: Educom, 1976.

SNELL-HORBY, Mary. "A "estrangeirização" de Venuti: o legado de Friedrich Schleiermacher aos Estudos da Tradução?" Trad. de Marcelo Victor de Souza Moreira. In: Pandaemonium, São Paulo, v. 15, n. 19, Jul./2012, p. 185-212. Disponível em: http://www.revistas.usp.br/pg/article/viewFile/39802/42666. Acesso em 25 jun. 2014.

SCHLEIERMACHER, Friedrich. "Über die verschiedenen Methoden des Übersetzens/Sobre os diferentes Métodos de Tradução". In: Clássicos da Teoria da Tradução. Antologia Bilíngue. Vol. 1. Alemão Português. Werner Heidermann (Org.). Florianópolis: UFSC/Nuplitt, 2010, p. 38-101.

VENUTI, Lawrence. The Translator's Invisibility. A History of Translation. London/New York: Routledge, 1995. 


\section{FORTUNA CRÍTICA}

ALCÂNTARA, Plácido. "A Etnopoesia de Hubert Fichte". Cadernos de Campo, São Paulo: v. 1, n. 1, p. 61 -67, 1991.

ARNOLD, Ludwig. (Org.). Text + Kritik. Hubert Fichte. Heft 72. München: Edition Text + Kritik, 1981.

BADER, Wolfgang. "Dos espaços da marginalidade alemã ao universo das culturas afroamericanas: vida e obra de Hubert Fichte". In: Etnopoesia, p. 9-28. São Paulo: Editora Brasiliense, 1987.

BECKERMANN, Thomas (Org.) Hubert Fichte. Materialien zu Leben und Werk. Frankfurt am Main: S. Fischer, 1985.

BÖHME, Hartmut; TILING, Nikolaus (Org.). Leben, um eine Form der Darstellung zu erreichen. Studien zum Werk Hubert Fichtes. Frankfurt am Main: S. Fischer, 1991.

BRAUN, Peter. Die doppelte Dokumentation - Fotografie und Literatur im Werk von Leonore Mau und Hubert Fichte. Stuttgart: Metzler, 1997.

FISCH, Michael. Personalbibliographie zu Leben und Werk von Hubert Fichte. Berlim: Edition diá, 1996.

Verwörterung der Welt. Über die Bedeutung des Reisens für

Leben und Werk von Hubert Fichte. Orte - Zeiten - Begriffe. Aachen: Rimbaud, 2000 .

Rimbaud, 2005.

Gesten und Gespräche über Hubert Fichte. Aachen:

FUHSE, Mario. Der Platz des "Platzes": Gestalt- und raumtheoretische Kontextualisierungen zu Hubert Fichtes Roman Der Platz der Gehenkten. Hamburg: Männerschwarm Verlag, 2014.

GILLET, Robert. "Ein Verständigungstext ist es gewi $\beta$ nicht". In: BRAUN, P.; WEINBERG, M. (Orgs.). Ethno/Graphie: Reiseformen des Wissens. Tübingen: Gunter Narr Verlag, 2002. p. 180-181

HABERMANN, Otto. Carta de Habermann a Fichte, 28. 04. 1958. In: NHF 27.2 (Espólio de Hubert Fichte).

HEINRICHS, Hans-Jürgen. "Realidades afrobrasileiras na obra de Hubert Fichte" In: Revista Humboldt, no 63, p. 52-57. São Paulo: 1992. 
HEIßENBÜTTEL, Helmut. Strategie der Erzählkunst. Über Hubert Fichtes Roman „Das Waisenhaus”. In: Süddeutsche Zeitung. 11.09.1965.

Vaudou als Reise nach innen. Hubert Fichte und Leonore Mau über afroamerikanische Religionen - Bahia, Haiti, Trinidad. In: Die Zeit. 8.10/1976

LAEMMLE, Peter. Hubert Fichte im Gespräch. In: Norddeutscher Rundfunk. 28.10.1980

LINDEMANN, Gisela. In Grazie das Mörderische verwandeln (. Ein Gespräch mit Hubert Fichte zu seinem roman fleuve "Die Geschichte der Empfindlichkeit«. In: Sprache im technischen Zeitalter 104: 308.

RIEGER, Michael. Die Welt durch sich hindurch lassen: Hubert Fichtes Werk als Medium ästhetischer Erkenntnis. Frankfurt am Main: Peter Lang GmbH Internationaler Verlag der Wissenschaften, 2009.

TEICHERT, Torsten. Herzschlagen nach aussen. Die poetische Konstruktion des Fremden und des Eigenen im Werk von Hubert Fichte. Frankfurt a. M.: S. Fischer, 1987.

WISCHENBART, R. "Ich schreibe, was mir die Wahrheit zu sein scheint". Ein Gespräch mit Hubert Fichte. In: text und kritik 72 (1981), S. 67-85.

\section{OUTRAS OBRAS CONSULTADAS}

ACKERMANN, Marion. Drei: Das Triptychon in der Moderne. Berlim: Hatje Cantz Verlag, 2009.

AGUIAR E SILVA, Vitor Manuel de. Teoria da literatura. São Paulo: Martins Fontes, 1976.

ALMEIDA, Rodrigo Davi. A visita de Sartre e Beauvoir ao Brasil. Disponível em: http://redeglobo.globo.com/globociencia/noticia/2011/09/visita-de-sartre-ebeauvoir-ao-brasil.html. Acesso em 16 maio 2017.

ARANTES, Poliana Coeli Costa. "Ficção e Realidade nos conteúdos enunciativos do Boulevardzeitung na Alemanha: o que mudou em 60 anos de existência". In: Revista UNIABEU, v. 5, nº 11, set.-dez., 2012.

ARTE Pop. In: ENCICLOPÉDIA Itaú Cultural de Arte e Cultura Brasileiras. São Paulo: Itaú Cultural, 2017. Disponível em <http: encyclopedia. Itaucultural. org.br/termo 367/arte-pop>. Acesso em 5. maio 2017.

BELÉM, Euler França. Canal 100, a voz dos militares e o futebol como você nunca viu, 2015. In: Jornal Opçao 41 anos. Disponível em: jornalopcao.com.br. Acesso em 28 mai. 2016 
10aㅡ BIENAL DE SÃO PAULO. In: ENCICLOPÉDIA Itaú Cultural de Arte e Cultura Brasileiras. São Paulo: Itaú Cultural, 2017. Disponível em <http: enciclopedia.itaucultural. org.br/termo 335/bienal-internacional-de-são-paulo>. Acesso em 5. maio 2017.

BIERNAT. Ulla. Ich bin nicht der erste Fremde hier. Zur deutschsprachigen Reiseliteratur nach 1945. Würzburg: Königshausen \& Neumann, 2004

CABRAL, Danilo Cezar. Papa Doc, o ditador que tocou terror no Haiti. In: Mundo Estranho, 2016. Disponível em: mundoestranho.abril.com.br. Acesso em 17 abr. 2016.

CACCIATORE, Olga Gudolle. Dicionário de Cultos Afro-brasileiros. Rio de Janeiro: Editora Forense Universitária, 1977.

CAMARA JR., J. História da Língua Portuguesa. Rio de Janeiro: Padrão, 1976.

CANDIDO, Antonio. "O direito à literatura". In: Vários escritos. $4^{\mathrm{a}}$ ed. São Paulo/Rio de Janeiro: Duas Cidades/Ouro sobre Azul, 2004, p. 169-191.

COMPAGNONCASTRO, Yeda Pessoa de. Falares africanos na Bahia: um vocabulário afrobrasileiro. Rio de Janeiro: Topbooks, 2005 [2001].

CORREIO DA MANHÃ. In: ARQUIVO NACIONAL. Rio de Janeiro: Ministério da Justiça e Segurança Pública, 2016. Disponível em: arquiconacional.gov.br/acervos-mais-consultados-titulo/correio-damanha.html. Acesso em 05 maio 2016.

DIE WELT. Disponível em: zeitung.welt.de. Acesso em 15 abr 2016.

DONDIS, Donis A. Sintaxe da linguagem visual. São Paulo: Martins Fontes, EDWARDS, Kathleen. Lil Picard and the Counterculture of New York. Disponível em: uima.iowa.edu/lilpicard. Acesso em 25 maio 2016.

FALCÃO, Norton; LIMA, Lídia Farias. A Ilustração no projeto gráfico das capas da revista Piauí. Intercom - Sociedade Brasileira de Estudos Interdisciplinares da Comunicação XII Congresso de Ciências da Comunicação na Região Nordeste - Campina Grande - PB - 10 a 12 de Junho 2010

FERRAZ, Alex (org.). Tribuna 40 anos de Bahia. Salvador: Bamboo Editora, 2010.

FERREIRA, Aurélio Buarque de Holanda. Novo Aurélio Século XXI: o dicionário da língua portuguesa. Rio de Janeiro: Nova Fronteira, 1999.

FUNDAÇÃO BIBLIOTECA NACIONAL. Catálogos de livros. Autores: Fichte, Hubert. Disponível em:

http://consorcio.bn.br/scripts/odwp032k.dll?t=bs\&pr=livros_pr\&db=livros\&ss=n ew\&disp=card\&use=pn\&arg=fichte,\%20hubert. Acesso em: 13 out. 2014. 
GAMA, Ligia Barros. Kosi Ejé Kosi Orixá. Simbolismo e representação do sangue no candomblé. Dissertação de mestrado. Programa de Pós-Graduação em Antropologia, Universidade Federal de Pernambuco, 2009.

GENETTE, G. Paratextos Editoriais. Tradução de Álvaro Faleiros. Cotia, SP: Ateliê Editorial, 2009.

HEIDEGGER, M. Ser e Tempo: parte II. 2ª ed. Trad. Márcia de Sá Cavalcanti. Petrópolis: Vozes, 1998.

HERNANDEZ, Oswaldo. Ditadura militar: propaganda, terrorismo e manifestações populares. Disponível em:

http://memoriasoswaldohernandez.blogspot.com.br/2012/10/historia-dosanos-70 27.html. Acesso em 16 abr. 2016.

JAKOBSON, Roman. "Aspectos linguísticos da tradução". In: Linguística e Comunicação. São Paulo: Editora Cultrix, 2001, p. 63-72.

KILLY LITERATURLEXIKON. Autoren und Werke des deutschsprachigen Kulturraums. Vol. 6 Huh-Kräf. Berlim: Walter de Gruyter, 2009, p. 62-63.

LELIÈVRE, Marie-Dominique. Brigitte Bardot. Rio de Janeiro: Record, 2014.

MARX, Karl; ENGELS, Friedrich. Manifest der Kommunistischen Partei. Ditzingen: Reclam, 1986.

MILLER, Herman. Quem é a Herman Miller? Nossa história. Disponível em: hermanmiller.com.br. Acesso em 08 ago. 2016

MIRANDA, Francisco. Medalhas \& Condecorações: A Cruz de Ferro. Disponível em: chicomiranda.wordpress.com/2011/06/17/medalhascondecoracoes-a-cruz-de-ferro. Acesso em 15 abr. 2017.

MONTEIRO, Raul. "Milhões e lágrimas na venda do jornal A Tarde". Disponível em: http://www.politicalivre.com.br/2015/10/milhoes-e-lagrimas-na-venda-dojornal-a-tarde/. Acesso em 15 abr. 2016.

MOSCOVICI, Serge. A representação social da psicanálise. Rio de Janeiro: Zahar, 1978.

MUNDO DAS MARCAS. Maggi: Muito mais que um caldo nobre.

Disponível em: http://mundodasmarcas.blogspot.com.br/2006/05/maggi-muitomais-que-um-caldo-nobre.html. Acessos em 15. Apr 2016.

PRANDI, Reginaldo. Mitologia dos Orixás. São Paulo: Companhia das Letras, 2009.

PRANDI, Reginaldo; VALLADO, Armando. "Xangô, Rei de Oió". Disponível em: http://www.fflch.usp.br/sociologia/prandi/xangorei.htm. Acesso em 05 maio 2017. 
REVISTA PROSA E VERSO. Disponível em:

http://www.revistaprosaversoearte.com/quirinus-kuhlmann-poemas/. Acesso em 27 abr. 2017.

RIBEIRO, Belisa. Jornal do Brasil. História e Memória. Rio de Janeiro: Record, 2015.

SANTORI, Jorge. Brigitte Bardot e Pelé, 1971.

Disponível em: http://antiguinho.blogspot.com.br/2014/06/brigitte-bardot-epele-1971.html. Acesso em 16 abr. 2016.

SANTOS, Roberto Albuquerque. Propaganda política do governo Médici.

Disponível em:

http//:falandodeteologiaehistoria.blogspot.com.br/2012/01/propaganda-

politica-do-governo-medici.html. Acesso em 16 abr. 2016.

SARACENI, Rubens. Doutrina e Teologia da Umbanda Sagrada. A religião dos mistérios. Um hino de amor à vida. São Paulo: Madras Editora, 2010.

SARKOWICZ, Hans; MENTZER, Alf (Org.). Literatur in Nazi-Deutschland. Ein biografisches Lexikon. Hamburgo, Viena: Europa Verlag, 2000.

SARTRE, Jean-Paul. O que é literatura? São Paulo: Editora Ática, 2004.

SCALZO, Marília. Jornalismo de Revista. São Paulo: Contexto, 2003.

SCHøLLHAMMER, Karl Erik. Além do visível: o olhar da literatura. Rio de Janeiro: 7Letras, 2007.

SCHWARTZ, Michael. Homossexuelle im Nationalsozialismus. München: De Gruyter, 2014.

SILVA, Priscilla Ramos da. Os Acionistas Vienenses: revolucionários ou perversos? VI Encontro de História da Arte. IFCH/UNICAMP. Campinas, 2008: 240.

SÖREN, Gunnarsson. Victor Hasselblad 1906 - 2006. A short biography. Göteborg: Victor Hasselblad AB, 2006.

SÖRGEL, Rita. Rübenmus und Schwarzsauer - oder: sie heiratet já doch. Eine Kindheit und Jugend in der Kriegs- und Nachkriegszeit in Kiel. Kiel: Armani International Publishing, 2009.

SPALDING, Tassilo Orpheu. Dicionário de Mitologia Greco-Latina. São Paulo: Cultrix, 1982.

TOLEDO, Dionísio de Oliveira Toledo (org.). Teoria da literatura: formalistas russos. Porto Alegre: Globo, 1978.

UERLING, Herber. Poetiken der Interkulturalität: Haiti bei Kleist, Seghers, Müller, Buch und Fichte. Tübingen: Niemeyer, 1997. 
WELKER, Herbert Andreas. Gramática alemã. Brasília: Editora Universidade de Brasília, 2004.

ZAMPIERI, Luigi. Histórias de São Francisco.

Disponível em: http://verbo-pai.blogspot.com.br/2012/10/historias-de-saofrancisco-de-assis.html. Acesso em 23 abr. 2017.

\section{DICIONÁRIOS}

AQUIEN, M.; MOLINIÉ, G. Dictionnaire de rhétorique et de poétique. Paris: Libr. générale française, 1999.

AUTRAN DOURADO, Henrique. Dicionário de termos e expressão da música. São Paulo: Editora 34, 2004.

CRAVO ALBIN, Ricardo. Dicionário Cravo Albin da Música Popular Brasileira. Disponível em: http://www.dicionariompb.com.br. Acesso em 16 abr. 2016.

DICCIONARIO ESPAÑOL. Disponível em: http://www.acanomas.com.

DICIONÁRIO ONLINE DE PORTUGUÊS. Disponível em: dicio.com.br. DUDEN. Duden Online. Disponível em: http://www.duden.de/.

FERREIRA, Aurélio Buarque de Holanda. Novo Aurélio século XXI: dicionário da língua portuguesa. Rio de Janeiro: Nova Fronteira, 1999.

MUNDMISCHE - Wörterbuch der deutschen Umgangssprache und Spaß mit Sprichwörtern (Dicionário de gíria alemã e diversão com provérbios e expressões). Disponível em: http://www.mundmische.de.

PRIBERAM. Dicionário de Língua Portuguesa. Disponível em: $<$ www.priberam.pt/DLPO/ >.

SENSAGENT. Dicionário. Disponível em: http://dicionario.sensagent.com.

\section{EPÍGRAFE}

LAPLANTINE, François. Aprender Antropologia. São Paulo: Brasiliense, 2006.

MAIAKÓVSKI, Vladimir. Poética. Como fazer versos. Rio de Janeiro: Global, 1991. 


\section{ANEXO: CD-ROM}

A mídia aqui apresentada contém as versões das traduções de Xangô. As religiões afroamericanas. Bahia. Haiti. Trinidad. Os arquivos se encontram em formato pdf e podem ser abertos por meio de programas como Adobe Acrobat Reader ou Foxit Reader. 